\title{
RETRATOS DE UMA TRAJETÓRIA: Pibid/UCS - 2014 a 2018
}

\section{ANAIS}

II Seminário Institucional do Pibid-UCS

\section{Gládis Franck da Cunha}

Maria Helena Wagner Rossi

Suzana Maria Lain Pagot

ORGANIZADORAS 


\title{
Retratos de uma trajetória: Pibid/UCS - 2014 a 2018
}

\author{
ANAIS \\ II Seminário Institucional do Pibid-UCS
}

9 e 10 de março de 2018

\section{Organizadoras \\ Gládis Franck da Cunha}

Bacharel em Ciências Biológicas com Ênfase em Genética (UFRGS - 1982), Mestre em Genética e Biologia Molecular (UFRGS - 1987) e Doutor em Educação (UFRGS - 1999). Atualmente é professora da Universidade de Caxias do Sul, atuando nas disciplinas da Licenciatura e Bacharelado em Ciências Biológicas: Biologia Celular, Citogenética, Histologia, Bioquímica I e II, Modelos e Processos Evolutivos e Estágios Didáticos. É coordenadora de área do subprojeto PIBID/Ciências Biológicas/CARVI. Faz parte do corpo docente estruturante do Mestrado Profissional em Ensino de Ciências e Matemática da UCS, atuando nas disciplinas de Tópicos em Biologia I e Il e Interdisciplinaridade em Ensino de Ciências e Matemática. Especializou-se em Genética Ecológica e Evolutiva e em Biologia do Conhecimento, atuando principalmente nos seguintes temas: educação, prática educativa, biologia do conhecimento e neuroeducação. Edita e publica hipertextos sobre biologia do conhecimento, artigos didáticos e de divulgação científica sobre temas da Biologia e textos sobre Ensino de Ciências e Biologia, no blog: http://www.teliga.net. Membro do corpo editorial da Revista RICAUCS: http://www.ucs.br/etc/revistas/index.php/ricaucs/index CRBio: 63147-03D

\section{Maria Helena Wagner Rossi}

Graduada em Licenciatura em Desenho e Plástica. Mestre e Doutora em Educação na Universidade Federal do Rio Grande do Sul. Professora Titular da Universidade de Caxias do Sul (UCS) no Curso de Artes Visuais.

Professora de Arte aposentada da rede estadual de ensino do Rio Grande do Sul. Líder do Grupo

Interdisciplinar Arte, Cultura e Patrimônio - CNPq/UCS e vice-líder do Grupo de Pesquisa em Educação e Arte (GEARTE) - CNPq/PPGEDU/UFRGS. É coordenadora do Comitê de Ética em Pesquisa da Universidade de Caxias do Sul. É membro do Conselho de Representantes da FAEB. Foi vice-presidente da FAEB (Federação de Arte-Educadores do Brasil no biênio 2014-2016). Tem publicado artigos em revistas e capítulos de livros sobre leitura de imagens e compreensão estético-visual. É autora do livro Imagens que falam: leitura da arte na escola, publicado pela Editora Mediação (5a ed.: 2011; PNBE: 2011)

\section{Suzana Maria Lain Pagot}

Possui graduação em Licenciatura Plena em Letras Português pela Universidade de Caxias do Sul (1989), graduação em Letras Língua e Literatura Espanhola pela Universidade de Caxias do Sul (1998) e mestrado pela Universidade de Caxias do Sul (2004). Doutora em Literatura Brasileira pela UFRGS (2013). Professora da Universidade de Caxias do Sul. Tem experiência na área de Letras, com ênfase em Literatura e Língua Portuguesa, atuando principalmente nos seguintes temas: leitura e produção textual, ensino, literatura brasileira, literatura digital, língua espanhola, comunicação oral e português para estrangeiros.

Coordenadora do subprojeto de Letras-Português do Programa Institucional de Bolsa de Iniciação à Docência - PIBID.

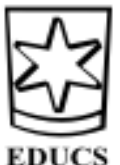


FUNDAÇÃO UNIVERSIDADE DE CAXIAS DO SUL

Presidente:

Ambrósio Luiz Bonalume

Vice-Presidente:

José Quadros dos Santos

UNIVERSIDADE DE CAXIAS DO SUL

Reitor:

Evaldo Antonio Kuiava

Vice-Reitor e Pró-Reitor de Inovação e Desenvolvimento Tecnológico:

Odacir Deonisio Graciolli

Pró-Reitor de Pesquisa e Pós-Graduação:

Nilda Stecanela

Pró-Reitor Acadêmico:

Marcelo Rossato

Diretor Administrativo:

Cesar Augusto Bernardi

Chefe de Gabinete:

Gelson Leonardo Rech

Coordenador da Educs:

Renato Henrichs

\section{CONSELHO EDITORIAL DA EDUCS}

Adir Ubaldo Rech (UCS)

Asdrubal Falavigna (UCS)

Cesar Augusto Bernardi (UCS)

Guilherme Holsbach Costa (UCS)

Jayme Paviani (UCS)

Luiz Carlos Bombassaro (UFRGS)

Nilda Stecanela (UCS)

Paulo César Nodari (UCS) - presidente

Tânia Maris de Azevedo (UCS) 
(C) dos organizadores

Dados Internacionais de Catalogação na Publicação (CIP)

Universidade de Caxias do Sul

UCS - BICE - Processamento Técnico

S471r Seminário Institucional do Pibid-UCS (2. : 2018 mar. 9-10 : Caxias do Sul, RS)

Retratos de uma trajetória [recurso eletrônico] : Pibid-UCS - 2014 a 2018: anais do II Seminário Institucional do Pibid-UCS / org. Gládis Franck da Cunha, Maria Helena Wagner Rossi, Suzana Maria Lain Pagot. - Caxias do Sul, RS: Educs, 2018.

Dados eletrônicos (1 arquivo).

Apresenta bibliografia.

Modo de acesso: World Wide Web.

ISBN 978-85-7061-913-6

1. Educação - Congressos. 2. Professores - Formação. 3. Aprendizagem. I. Cunha, Gládis Franck da. II. Rossi, Maria Helena Wagner. III. Pagot, Suzana Maria Lain. IV. Título. V. Título: Anais do Seminário Institucional do Pibid-UCS.

CDU 2.ed.: 37(062.552)

Índice para o catálogo sistemático:

1. Educação - Congressos

$37(062.552)$

2. Professores - Formação

37.011.3-051

3. Aprendizagem

Catalogação na fonte elaborada pela bibliotecária

Carolina Machado Quadros - CRB 10/2236.

Direitos reservados à:

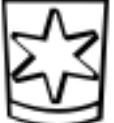

EDUCS

EDUCS - Editora da Universidade de Caxias do Sul

Rua Francisco Getúlio Vargas, 1130 - Bairro Petrópolis - CEP 95070-560 - Caxias do Sul - RS - Brasil

Ou: Caixa Postal 1352 - CEP 95001-970- Caxias do Sul - RS - Brasil

Telefone/Telefax PABX (54) 32182100 - Ramais: 2197 e 2281 - DDR (54) 32182197

Home Page: www.ucs.br-E-mail: educs@ucs.br 


\section{PROGRAMA INSTITUCIONAL DE BOLSAS DE INICIAÇÃO À DOCÊNCIA Pibid-UCS}

Coordenação Institucional: Vanderlei Carbonara

Secretária do Pibid-UCS: Elizete Carmen Ferrari Balbinot

\section{Subprojetos:}

Artes Plásticas e Visuais - Caxias do Sul Coordenador de Área - Maria Helena Wagner Rossi EMEF Santa Corona - Supervisora: Raquel Crocoli Longhi EMEF Caldas Júnior - Supervisora: Rosebel Rech

Ciências Biológicas - Caxias do Sul Coordenador de Área - Wilson Sampaio de Azevedo Filho EEEM Irmão Guerini - Supervisora: Angélica Ferrari Rodrigues CE Imigrante - Supervisora: Grasiela Aparecida Pasinato

Ciências Biológicas - Bento Gonçalves Coordenador de Área - Gladis Franck da Cunha EEEM Mestre Santa Bárbara - Supervisora: Luciana Bonato Lovato

Educação Física - Vacaria

Coordenador de Área - Eliete Maria Scopel

EEEB José Fernandes de Oliveira - Supervisora: Lisiane Cezar dos Santos Zermiani

Filosofia - Caxias do Sul

Coordenador de Área - Luis Fernando Biasoli

EEEM São Caetano - Supervisora: Tenisa Zanoto Boeira

História - Caxias do Sul

Coordenador de Área - Eliane Machado Corrêa Cardoso

EMEF Presidente Tancredo de Almeida Neves - Paulo Afonso Lovera Marmentini

EEEM Melvin Jones - Fabrícia Clave

Interdisciplinar (História e Sociologia) - Caxias do Sul

Coordenador de Área - Eliana Rela

EMEF Governador Leonel Brizola - Supervisor: Márcio Rodrigues

EEEM Professor Apolinário Alves dos Santos - Supervisora: Suélen Cristina Boeck Araújo

Letras - Espanhol - Caxias do Sul

Coordenador de Área - Elsa Monica Bonito Basso

EEEM Província de Mendoza - Supervisora: Laiana Bittencourt Cardoso

Letras - Inglês - Caxias do Sul

Coordenador de Área - Maria Valesia Silva da Silva

EEEM Santa Catarina - Supervisora: Marcia Zambon Farias 
Letras - Português - Caxias do Sul

Coordenador de Área - Suzana Maria Lain Pagot

CE Imigrante - Supervisora: Silvete Maria Muller

Letras - Português - Bento Gonçalves

Coordenador de Área - Odete Maria Benetti Boff

EEEM Mestre Santa Bárbara - Supervisora: Daniela Montipó

Matemática - Caxias do Sul

Coordenador de Área - Ana Cristina Possapp Cesa

EEEM São Caetano - Supervisora: Leonise Maria Facchin

Música - Caxias do Sul

Coordenador de Área - Luís Ortiz Oliveira Filho

Instituto Estadual de Educação Cristóvão de Mendoza - Supervisora: Mariá Claudete Issler Vaz

Pedagogia - Caxias do Sul

Coordenador de Área - Cristiane Backes Welter

EMEF Zélia Rodrigues Furtado - Supervisora: Márcia Regina Giacomelli Schleder

Pedagogia - Vacaria

Coordenador de Área - Olivia Mélo da Silva

EMEF Juventina Morena de Oliveira - Supervisora: Márcia de Aguiar Constante 


\section{A. ARTIGOS COMPLETOS}

Artes Plásticas e Visuais e Educação Física

1 A RELEVÂNCIA DO ENSINO DA ARTE LATINO-AMERICANA

Jacks Ricardo Selistre

2 ARTE CONCEITUAL NO PROCESSO DE DESENVOLVIMENTO ESTÉTICO DE ADOLESCENTES

Bruna Scherner da Silva

3 COMPOSIÇÃO VISUAL COMO MEIO PARA UM FAZER ARTÍSTICO CONSCIENTE NA ESCOLA FUNDAMENTAL

Anelise de Oliveira Müller e Ketlim Favero Machado

4 CONTRIBUIÇÕES E APRENDIZAGEM DOS SUJEITOS ENVOLVIDOS NO SUBPROJETO DE EDUCAÇÃO FÍSICA

Camila Carraro Poletto, Lisiane Ambrosio Varella e Eliete Maria Scopel

5 TEMAS DO UNIVERSO CULTURAL DOS ESTUDANTES COMO CONTEÚDO DE ARTE.... 51 Alex Joacir Pessôa de Oliveira Júnior

\section{Ciências Biológicas}

6 A INICIAÇÃO À DOCÊNCIA COM PROJETOS DE HORTA ESCOLAR PARA O ENSINO DE CIÊNCIAS

Gladis Franck da Cunha, Lisiane de Souza, Luana Boeira e Tatiane Eitelven

7 ESTRATÉGIA PRÁTICA PARA ENSINO DE PALEONTOLOGIA

Willian Lando Czeikoski, Aline de Godoy e Kétini Mafalda Sacon Baccin

8 O PIBID-BIOLOGIA NA REVITALIZAÇÃO DOS LABORATÓRIOS NAS ESCOLAS

PARCEIRAS

Ana Paula de Souza, Bruna Trevisol Dupont, Gladis Franck da Cunha, Luciana Bonato Lovato e Raquel de Villa

Interdisciplinar (História e Sociologia), Filosofia e História

9 NECESSIDADES HUMANAS COMO FUNDAMENTO PARA A EDUCAÇÃO ..................... 95

Fernanda Dinarowski

10 O CONCEITO COMO METODOLOGIA NAS PRÁTICAS DO PIBID/UCS-FILOSOFIA..... 106

Patric de Oliveira Peres

11 PERFIL SOCIOANTROPOLÓGICO DOS ESTUDANTES DA ESCOLA PROFESSOR APOLINÁRIO ALVES DOS SANTOS.

Bruno Rodrigues da Silva Damin, Deivid da Silva Ferreira, Drieli Munique de Matos Tibola, Gabriela Gonzalez Matias, Letícia Turella Tonolli, Luciana Cassol da Silva, Nátali Di Domenico Santos, Rafael Pinheiro e Suélen Cristina Boeck

12 PIBID/ INTERDISCIPLINAR - UCS: UM OLHAR A PARTIR DA MEDIAÇÃO DOCENTE ... 127 Márcio Rodrigues 
13 SAÍDAS A CAMPO COMO ESTRATÉGIA PARA O ENSINO INTERDISCIPLINAR

Geovana Erlo

14 TEMÁTICAS E DILEMAS ÉTICOS DO LÚDICO: O DESAFIO DO ENSINO DE ÉTICA NAS ESCOLAS A PARTIR DE UMA EXPERIÊNCIA DO PIBID/UCS DE FILOSOFIA................. 148 Luís Fernando Biasoli

15 UMA BREVE INTERPRETAÇÃO SOBRE "A NÁUSEA" DE JEAN PAUL SARTRE 158 Danimar Bonai e Suzy Menegat

Letras Inglês e Pedagogia

16 A REPRESENTAÇÃO FEMININA EM SALA DE AULA 163 Igor Filipini Cearon e Juliana Cordeiro Begnini

17 EGOCENTRISMO: DIVERGÊNCIAS ENTRE O ESTUDO DO CONCEITO E A ATUAÇÃO DOCENTE DO PIBID NA EDUCAÇÃO INFANTIL.

Cristiane Backes Welter, Márcia Regina Giacomelli Schleder e Karlani Machado

\section{B. RESUMOS EXPANDIDOS E RELATOS DE EXPERIÊNCIA}

\section{Artes Plásticas e Visuais e Música}

18 AULAS DE MÚSICA PARA O ENSINO NORMAL - RELATO DE EXPERIÊNCIA 183 Miraci Jardim, Mateus Castilhos, Leandro Lindemann e Liruan Cortelett

19 CONTRIBUIÇÕES DA ARTE NO AMBIENTE ESCOLAR 191 Laura Smiderle e Ana Felisberto

20 COR E FORMA NAS AULAS DE ARTE NO ENSINO FUNDAMENTAL 194 Carina Pasqual

\section{Ciências Biológicas e Matemática}

21 AÇÕES COLABORATIVAS NO ENSINO E NA APRENDIZAGEM DE MATEMÁTICA .... 197 Leonise Maria Facchin, Suélen Cristina dos Santos

22 ATUAÇÃO DO PIBID-BIOLOGIA/UCS NA ESCOLA ESTADUAL IRMÃO GUERINI ........ 201 Angélica Ferrari Rodrigues, Meliny Dalla Bona Gallio, Andreia Won Miller, Gabriela Rodrigues Alves, Gustavo Blanco Correa, Josiana Pasa Zampieri e Wilson Sampaio de Azevedo Filho

23 ATUAÇÃO DO PIBID BIOLOGIA/UCS NO COLÉGIO ESTADUAL IMIGRANTE 207 Allana Della Giustina Salami, Grasiela Aparecida Pasinato, Henrique Pasinato de Souza, João Vitor Morés Pereira, Leia Ribeiro dos Santos, Natália Dallavechia de Col, Rafaela Schiochet e Wilson Sampaio de Azevedo Filho

24 DUAS PROPOSTAS PARA O USO DE TICS NO ENSINO DE CIÊNCIAS 211 Aline de Godoy, Kétini Baccin, Willian Lando Czeikoski, Igor Pozzebon, Thaisa Dal Pizzol, Gladis Franck da Cunha e Ariane Pegoraro Nuncio

\section{Interdisciplinar (História e Sociologia) e Filosofia}

25 A APLICABILIDADE DA AVALIAÇÃO POR CONCEITOS NO ENSINO MÉDIO 215 Anderson Boppsin da Silva 
26 ATIVIDADE SOBRE FILOSOFIA DA NATUREZA EM SALA DE AULA

Mateus da Silva Maciel

27 FÍSICA E A HISTÓRIA DO CALOR: RELATO DE UM PROJETO INTERDISCIPLINAR ..... 225

Gabriela Gonzalez Matias

28 INCLUSÃO E EXERCÍCIO DE CIDADANIA NO PIBID-UCS HISTÓRIA

Alessandra Cardoso

29 O PENSAMENTO SOCIOLÓGICO COMO FORMA DE EMANCIPAÇÃO E

TRANSFORMAÇÃO

Steffany Cardoso

30 O PIBID COMO INCENTIVO À PRÁTICA E À CARREIRA DOCENTE

Carolina Franchesca Silva de Lima e Éverton Luiz Ferri

31 POVOS INDÍGENAS AMERICANOS: REFLEXÕES SOBRE A PRÁTICA PEDAGÓGICA ..... 240

Bárbara Moreschi, Daniela Prestes, Paulo Afonso Lovera Marmentini

e Rafael Stamm Marcolin

32 RETROSPECTIVA DO PIBID-UCS FILOSOFIA: SOMAS, ANSEIOS, PROSPECTIVAS ..... 244

Tenisa Zanoto Boeira

\section{Letras Português, Inglês e Pedagogia}

33 ATIVIDADE E UTILIDADE DO GOOGLE DRIVE.

Tainá Reis Dorneles e Paula Nicole Scholl Morelato

34 CULTURA EM SALA DE AULA: RELATO DE HALLOWEEN.

Bruna Borges e Susana Souza

35 O PROFESSOR MEDIADOR NA LEITURA LITERÁRIA EM SALA DE AULA

Marina Bernardo Alves

36 PIBID: A SALA DE AULA COMO ESPAÇO DE EMANCIPAÇÃO DOS SUJEITOS.

Anna Carolina Pasquali e Raissa Lauana Antunes da Silva

37 RELAÇÕES POSSÍVEIS ENTRE AS EXPERIÊNCIAS NO PIBID E AS PRÁTICAS

EM ESTÁGIO DOCENTE

Jasmine Cristina Busetti

38 RELATO DE EXPERIÊNCIA DO PIBID/PEDAGOGIA UCS-VACARIA-2017

Fabiana Pastore Consorte, Jeniffer Maciel Giordano, Marcela Lopes, Márcia de Aguiar Constante, Olivia Mélo da Silva e Taís Zanella Bortolon

39 RELATO E ANÁLISE DE EXPERIÊNCIA DA OFICINA DO ENEM.

Thais de Oliveira e Camila Fin Martins

40 UMA PROPOSTA PARA O ESTUDO DE GÊNEROS TEXTUAIS SUBPROJETO

PIBID-UCS-CARVI LETRAS/PORTUGUÊS.

Camila Fernanda Ferreto Jaques 


\section{Apresentação}

O II Seminário Institucional do Pibid-UCS, realizado em março de 2018, abordou a trajetória de quatro anos do Projeto Institucional desenvolvido na Universidade de Caxias do Sul/RS, de março de 2014 a fevereiro de 2018. A partir do Edital da Capes (Portaria 096, de 18 de julho de 2013), foram desenvolvidos 16 subprojetos: Artes Plásticas e Visuais; Biologia (Campus-Sede e Carvi); Educação Física; Filosofia; História; Interdisciplinar (História e Sociologia); Letras (Espanhol); Letras (Inglês); Letras (Português - Campus-Sede e Carvi); Matemática; Música; Pedagogia (Campus-Sede e Camva) e Química.

As ações desenvolvidas pelos subprojetos visaram à efetiva aproximação entre universidade e escola, como fator fundamental no processo da formação inicial dos licenciandos. Professores coordenadores, professores supervisores e bolsistas de iniciação à docência engajaram-se na busca da concretização dos objetivos deste Programa nacional, que teve como foco a inserção dos graduandos na escola pública.

Uma análise dos relatórios dos subprojetos evidencia a postura críticoreflexiva dos bolsistas de iniciação à docência, em relação ao cotidiano escolar. Ainda, mostra a construção de uma visão sobre a escola como um lugar de aprendizagens, que enriquece a sua formação inicial, pela possibilidade de experienciar a indissociabilidade entre ação e reflexão.

Este e-book - intitulado Retratos de uma trajetória: Pibid/UCS (2014 a 2018) - apresenta a produção resultante da permanência dos quatro anos do Programa na Instituição. São artigos completos, resumos expandidos e relatos de experiência que revelam as repercussões das ações dos bolsistas de iniciação à docência, dos professores supervisores e dos coordenadores.

Ao longo dos textos, os bolsistas participantes do Pibid/UCS descrevem e analisam experiências relevantes e os resultados obtidos nas atividades realizadas em escolas e na própria UCS, de forma que o leitor possa se deliciar com estratégias docentes inovadoras, marcadas pela ousadia de ir além do mediano e buscar, na troca de experiências e nas reflexões teóricas pertinentes, uma educação com qualidade, capaz de promover a construção de saberes e o 
desenvolvimento da inteligência de crianças, adolescentes e jovens que estão na Educação Básica.

Nesta leitura, é possível compreender por que os projetos desenvolvidos pelos bolsistas dos subprojetos de Artes Plásticas e Visuais e Música levaram em conta que a arte, além de ser expressão de subjetividades, é cultura, atuando, portanto, em contextos enraizados socialmente; e, também, por que os bolsistas dos subprojetos de Biologia, de Matemática e de Educação Física criaram materiais didáticos, bem como exploraram recursos tecnológicos e revitalizaram espaços escolares ou laboratórios, para proporcionar experiências de ensino, com atividades práticas e recursos lúdicos, que possibilitaram uma aprendizagem significativa.

Ao mergulhar nos subprojetos das áreas de Humanidades, o leitor vai refletir sobre o papel da disciplina de Filosofia, que tem a ética como um conteúdo atitudinal, conceitual e procedimental, ou os desafios que a leitura de imagens, como metodologia, impõe ao ensino de História. Na abordagem do subprojeto interdisciplinar, as Tecnologias de Informação e Comunicação são tratadas como um contexto de acesso à informação e produção, que demanda a urgente necessidade de aproximar tal contexto das práticas de formação dos professores. Já as áreas de linguagens buscaram, por meio de estratégias diversificadas, cativantes e criativas, desafiar os estudantes a serem leitores mais qualificados e, consequentemente, escritores ou interlocutores mais autônomos. O subprojeto de Pedagogia desafiou as acadêmicas ao desprendimento de velhas práticas pedagógicas para atuar com ousadia.

Espera-se que esta socialização da experiência pibidiana, nos diversos subprojetos que constituíram o Projeto Institucional Pibid-UCS, possa incentivar estudantes de licenciaturas e professores em exercício na escola pública, para que valorizem a dialética relação entre teoria e prática, tanto na formação inicial quanto na educação continuada de professores.

As Organizadoras 


\title{
Arte Plásticas e Visuais e Educação Física
}

\author{
1
}

\section{A RELEVÂNCIA DO ENSINO DA ARTE LATINO-AMERICANA}

\author{
Jacks Ricardo Selistre* \\ jacksricardoselistre@gmail.com \\ Subprojeto de Artes Plásticas e Visuais \\ Escola Municipal de Ensino Fundamental Zélia Rodrigues Furtado
}

Resumo: O presente artigo apresenta a relevância de ensinar a arte latino-americana na Educação Básica. A partir de observações no cotidiano escolar, percebe-se o desconhecimento sobre a realidade latino-americana, que é consequência da forte influência cultural dos países do Hemisfério Norte-Ocidental. O isolamento e a falta de conhecimento da arte latino-americana, observados no contexto escolar, no âmbito do Pibid, são os motivadores para o desenvolvimento deste artigo. Não abordar o ensino da arte latino-americana é um modo de desprivilegiar a cultura do próprio país e dos países vizinhos. Neste artigo, pretende-se justificar a importância do ensino da arte latino-americana, permitindo que os estudantes tenham conhecimento daquilo que é produzido no Brasil e nos países vizinhos, buscando assim aproximar a arte ao estudante. Além, destacam-se as similaridades e as diferenças artísticas entre os países latino-americanos com os países do Hemisfério Norte, principalmente da Europa e dos Estados Unidos. Por meio da experiência do Pibid, conclui-se que a arte latino-americana não é, de fato, conteúdo abordado na escola estando segregada daquela que é considerada a arte universal. Por fim, defende-se a abordagem dessa temática na Educação Básica, a fim de construir uma nova narrativa sobre os aspectos culturais, principalmente artísticos, dos países latino-americanos.

Palavras-chave: Arte latino-americana. Educação Básica. PIBID Artes Plásticas e Visuais.

O interesse em pesquisar a arte latino-americana iniciou-se a partir de um intercâmbio para a Universidad del Salvador, em Buenos Aires, no ano de 2012. Durante o intercâmbio, realizou-se uma disciplina chamada Historia del Arte Latinoamericano, em que foram apresentadas as produções artísticas do século XX ao XXI na América Latina, explorando narrativas artísticas que, outrora, foram omitidas do discurso artístico universal. Essa disciplina motivou a escolha do tema deste artigo, que é a presença/ausência da arte latino-americana no sistema artístico $^{1}$ e educacional, bem como suas contribuições no ensino para

\footnotetext{
* Coordenadora: Profa. Dra. Maria Helena Wagner Rossi. Supervisora: Profa. Patrícia Festugato Roth.

${ }^{1}$ Sobre a ausência/presença da arte latino-americana no sistema das artes, tem-se o Trabalho de Conclusão de Curso do presente autor, denominado O lugar da arte latino-americana no século XXI. Além disso, pode-se acessar um fragmento deste estudo, pelo artigo de Jacks Ricardo Selistre
} 
os/as estudantes da Educação Básica. Ao ingressar no Programa Institucional de Bolsas de Iniciação à Docência (Pibid), no ano de 2013, teve-se contato com duas escolas de Educação Básica. Durante as observações nas escolas, percebeu-se que os conteúdos trabalhados em Arte focavam produções artístico-europeias, estado-unidenses e brasileiras, de modo que a arte latino-americana não era contemplada nas atividades em sala de aula. Essa constatação não se limita apenas à Educação Básica, mas também ao Ensino Superior, uma vez que poucas são as universidades no Brasil e na América Latina que possuem a disciplina de Arte Latino-Americana na grade curricular, conforme é afirmado por Aracy Amaral (2006).

Diante disso, pesquisas vêm sendo realizadas visando à valorização da arte latino-americana no contexto escolar, relacionando à sua ausência no sistema da arte - o qual se organiza por meio dos preceitos de: masculinidade, branquitude, heterossexualidade (GARCIA, 2004) e do domínio euro-estado-unidense. (AMARAL, 2006). Esses preceitos atuam de maneira excludente, fazendo com que as produções artísticas, que não as contemplem sejam ocultadas da história da arte, passando a ocupar as margens de uma história da arte que se pretende universal, sendo neste caso uma história das particularidades (LOPONTE, 2002) de determinado país, gênero, raça e classe. O modo de escrever a história da arte é excludente, visto que muitas narrativas foram omitidas em detrimento de outras. Entretanto, é importante destacar que a história da arte é um processo tanto de inclusão quanto de exclusão, e há outras histórias da arte que existem independentemente do cânone ocidental. ${ }^{2}$ (ARNOLD, 2008). Há histórias que não estão em livros, e ainda existem narrativas que precisam ser escritas, resgatadas ou reelaboradas. Os historiadores e filósofos estão habituados a uma história das sumidades (FOUCAULT, 2016), já que, ao construir uma narrativa, certas culturas são escolhidas em detrimento de outras, que atuam nas margens, subvertendo os cânones e mostrando novas possibilidades que foram outrora omitidas.

Diante desse cenário, pretende-se explorar as narrativas banidas e ocultadas pela história da arte, sobretudo da arte latino-americana, que foram

e Silvana Boone (orientadora). Disponível em:

$<$ http://www.unicamp.br/chaa/eha/atas/2015/Silvana\%20Boone\%20e\%20Jacks\%20 Ricardo\%20Selistre.pdf>.

${ }^{2}$ Por cânone da arte ocidental entendemos a arte produzida pelos sujeitos brancos, masculinos, heterossexuais, religiosos e europeus/estado-unidenses. 
omitidas em detrimento da arte produzida por sujeitos europeus e estadunidenses. Além disso, no contexto escolar é relevante proporcionar aos estudantes momentos para refletirem e analisarem os motivos para a ocultação de algumas culturas artísticas.

Neste sentido, pergunta-se o quão acessível é o museu para o artista latino-americano, negro, homossexual e para estudantes do Ensino Básico? A acessibilidade ao espaço expositivo não se restringe apenas ao artista, mas também ao público, uma vez que os espaços da arte são considerados espaços elitistas, aos quais apenas alguns sujeitos possuem real acesso. (BOURDIEU; DARBEL, 2007, p. 69).

Desse modo, propondo a inserção da arte latino-americana no sistema educacional, busca-se romper os limites educacionais e sistêmicos da arte, os quais se detêm no domínio ocidental euro-estadunidense, permitindo ao estudante uma outra perspectiva da arte em um contexto de globalização. Ao romper esses limites culturalmente pré-estabelecidos, será possível o acesso ao patrimônio cultural da humanidade (Rossı, 2011, p. 11), o qual se realiza por meio da educação e do questionamento de uma história "oficial e universal".

Pensar a universalidade de uma história, como a da arte, sugere certos cuidados, pois é inviável a construção de uma história "universal", principalmente quando se privilegia a cultura europeia e americana. Mas, faz-se necessário apresentar outras culturas artísticas, como a história latinoamericana, de uma filosofia latino-americana. Complementando essa perspectiva, Juan Bautista Alberdi (1986) afirma que não existe uma filosofia ou história universal. Cada época possui diferentes filósofias e diferentes vertentes artísticas, as quais possuem seus próprios discursos, associados a uma determinada cultura. Nesse sentido, é importante não generalizar discursos em uma filosofia ou história universal, já que, em cada filosofia e em cada história há interesses sociais, políticos e morais de países e sujeitos, que constroem sua própria história, uma história particular, não uma história universal.

Para desconstruir a ideia da existência de uma história universal e oficial, precisa-se inserir no contexto escolar outras culturas e permitir aos estudantes momentos de questionamentos sobre cada contexto. Assim, o ensino da arte latino-americana é importante para que os estudantes reconheçam outras culturas, além de valorizar as produções do nosso continente. Apenas abordando 
a arte latino-americana e seu contexto, conseguiremos perceber sua ausência sistemática em museus e, por conseguinte, nos currículos escolares e universitários. O conhecimento da história e da arte latino-americana nos reafirmará enquanto sujeitos deste continente, mostrará outros caminhos para o futuro e outros modos de interpretação de nosso passado.

Um desafio é pensar em como inserir esse conteúdo na Educação Básica, uma estratégia que relacione a arte brasileira à produção dos nossos países vizinhos. Essa estratégia irá permitir uma visão diferente do estereótipo latinoamericano e fortalecerá os laços com os países vizinhos, pois, hoje, prefere-se a abordagem cultural via Estados Unidos e Europa, sem atentar para os laços que deveriam ser estreitados com os vizinhos latino-americanos. (AMARAL, 2006).

Outro aspecto relevante é que, ao ensinar a arte latino-americana na Educação Básica, pode-se problematizar sobre as identidades nacionais, permitindo que os estudantes relacionem os sujeitos latino-americanos e suas culturas. O mapa do continente pode servir de base para compreender os países que compõem a América Latina, possibilitando associações de acordo com as fronteiras desses países. Nota-se que os países compartilham uma realidade social e cultural que, muitas vezes, é semelhante devido aos países que os colonizaram, evidenciando que a força das antigas metrópoles sobre as antigas colônias por vezes continuam (ALIAGA, 2010), inclusive no modo de escrever e abordar a história da arte. Observa-se que esses países possuem culturas e produções artísticas diferentes. As semelhanças artísticas e culturais que esses países possuem com o Brasil são características para estreitar nossos laços enquanto sujeitos que se reconhecem como latino-americanos, e as disparidades podem propiciar um aprendizado pelas diferenças (MISKOLCI, 2012), um aprendizado pela compreensão do outro, da sua cultural e de sua imagem.

À medida que se compara a arte latino-americana e a arte brasileira consegue-se perceber suas diferenças e suas semelhanças. Os contextos muitas vezes são similares, o que facilita o acesso dos estudantes a essas produções artísticas. Entretanto, a diferença proporciona a estranheza com o outro, com aquilo que não se conhece. As diferenças podem motivar os estudos, por meio das diferenças que a curiosidade desperta, possibilitando a identificação e a compreensão de novos significados culturais (LoURO, 2004), novas interpretações e significações. Qualquer obra de arte permite diferentes interpretações; não 
existe um único significado. A obra encontra-se aberta, inacabada, exigindo uma resposta livre, na qual o intérprete (res)significa a obra com o seu autor (ECO, 2013) e com o seu contexto econômico e cultural. Dessa maneira, percebe-se que toda obra é elaborada pelo menos duas vezes: pelo criador e pelo espectador, ou melhor, pela sociedade e cultura da qual o espectador faz parte. (BOURDIEU; DARBEL, 2011, p. 76). As obras de arte apresentadas aos estudantes são reinterpretadas de acordo com o contexto no qual se encontram, à medida que também servem para que os estudantes reconheçam os aspectos socioculturais do ambiente e do período em que a obra foi construída.

A leitura de uma imagem é uma capacidade imprescindível em nossa cultura, já que é possível deparar-se com elas diariamente, de modo direto e indireto. As leituras são construídas de acordo com os contextos nos quais os espectadores estão inseridos, bem como pelo conhecimento prévio que possuem acerca dessas imagens. Para construir o conhecimento prévio do contexto do qual essas imagens advêm, é necessária a contextualização das culturas e das sociedades. Esse processo faz com que a seleção de imagens e conteúdos seja abrangente e diversificada, incluindo tanto a arte erudita quanto manifestações populares e imagens advindas das mídias. (Rossı, 2011).

A construção de uma base cultural do outro pode ser realizada por meio de uma inserção sociogeográfica, em que são apresentados os países, localizandoos no mapa, relacionando suas histórias e tradições culturais. Um recurso interessante para essa construção é a música, sendo um modo de contextualizar os/as estudantes, abordando um outro idioma, as adversidades sociais, além de tornar o aprendizado mais prazeroso e divertido.

Ao utilizarem músicas e análise sociocultural, os/as estudantes estarão em contato com o contexto de determinados países, mostrando como a vida é vivida aí. Ao abordar a questão musical, o interesse é despertado através de duas músicas, uma música contemporânea que se volta ao pop, à cumbia, ao funk, ao reaggeton e a outras músicas eruditas ou populares. Dois tipos de música são utilizados para atrair o estudante: a música contemporânea e a música erudita ou popular. Ao utilizar duas expressões musicais diferentes, opta-se como método de análise da compreensão musical. A seleção de músicas de ordem diferentes instiga o pensamento, de modo que a seleção musical e imagética 
atenda às demandas estudantis, suscitando a compreensão musical e artística, percebendo detalhes e permitindo a existência de questionamentos.

Neste sentido, o critério de seleção das imagens deve estar de acordo com as idades, com os níveis de compreensão estética dos estudantes e também com suas vivências para que possam surgir leituras mais ricas e abrangentes, sendo necessária a contextualização do espaço, do período e da cultura analisados.

Ao proporcionar a leitura de imagem aos/às estudantes, cabe ao/à professor/a fazer o encaminhamento da leitura, de modo que ela seja contextualizada, abordando assim o contexto histórico e social em que realizouse a obra de arte. Com a contextualização, o/a estudante possui conhecimento para realizar outras interpretações, aumentando sua capacidade de análise. Apesar de uma obra ser aberta, a interpretação de sentidos deve seguir os rumos que a imagem proporciona. Deste modo, ao realizar a leitura existe uma criação colaborativa entre leitor, artista e contexto. No final do Ensino Fundamental e Médio, é possível buscar, junto com os/as estudantes, o sentido original das obras, mas sem privá-los(las) de ampliar as interpretações de acordo com suas subjetividades.

Incluir a arte latino-americana no contexto escolar possibilita maior proximidade dos/as estudantes com o objeto artístico latino-americano, possibilitando relacionar a arte à realidade; tornando o espaço educativo mais acessível, democrático e inclusivo. A inserção das expressões latino-americanas pode ser um motivador para o estudo e a compreensão das expressões artísticas estrangeiras. Além disso, o componente curricular Arte estará mais próximo do contexto geral das exposições de alcance internacional, visto que, nos últimos anos, as narrativas omitidas pela história da arte foram resgatadas e problematizadas pelas culturas visuais. (CRIMP, 1998). Como exemplo, destaco a exposição Les Magiciens de la tèrre, realizada em 1989 no Centre Pompidou de Paris. A curadoria, assinada por Jean-Hubert Martin, buscou apresentar a arte contemporânea por um viés não canônico, apresentando obras de artistas latinoamericanos, africanos, europeus e asiáticos, mostrando a multiculturalidade e a pluralidade das expressões artístico-contemporâneas. Na exposição foram proporcionados momentos para que artistas advindos de países não hegemônicos dialogassem com as produções artísticas dos países dominantes. 0 contato das diferentes produções possibilitou a abertura do sistema artístico, 
que antes se pautava exclusivamente pelas produções euro-estadunidenses. Les magiciens de la tèrre serve como exemplo de uma exposição importante para justapor as produções de artistas advindos de contextos hegemônicos com artistas que sobrevivem à margem da história oficial. Neste sentido, existe o questionamento da história que se posiciona como oficial e universal, que é fundamentada pelos livros e pela rede de ensino, em que o oficial e universal privilegia as produções de artistas homens, brancos, heterossexuais, europeus e estado-unidenses. A multiculturalidade dessa exposição possibilita que os estudantes compreendam as diferenças entre as produções, percebendo que uma história universal não seria possível em um contexto tão plural, já que as categorias não são grandes o suficiente para abarcar a diferença entre as pessoas. (SCOTT, 2005).

O interesse por temáticas contra-hegemônicas emergiu em 1978, com a exposição $A$ lesbian show com curadoria de Harmony Hammond, sendo considerada uma das primeiras exposições que subvertiam o sistema hegemônico, através das perspectivas queer. (BLANCA, 2017). Neste sentido, desde 1978 a história da arte vem sendo problematizada, a fim de desconstruir uma suposta história oficial e universal. A Educação Básica e Superior são importantes para a compreensão de uma história construída através de particularidades. Ao abordar produções artísticas latino-americanas novas subjetividades e significados seriam ativados nas obras, compreendendo que a história permanece a ser escrita.

Outra exposição relevante nesse sentido aconteceu em 2017, a Documenta de Kassel ${ }^{3}$ no 14, cuja curadoria contou com o teórico Paul B. Preciado, propôs a compreensão das obras como apátridas, focando a atenção nas obras e não na nacionalidade dos artistas, proporcionando leituras estéticas mais aguçadas e sem estereótipos. As produções dialogavam diretamente, sem basearem-se em nacionalidades. Assim as obras funcionam unicamente em suas questões estéticas, desvinculando-se do cânone ocidental, que se pauta na masculinidade, na branquitude, na heterossexualidade e no domínio euro-estado-unidense. A pluralidade ganhou voz e propôs deslocamentos e inversões, possibilitando narrativas que antes eram ocultadas em virtude do cânone instituído. Pensar a

${ }^{3}$ A Documenta de Kassel é realizada a cada cinco anos, desde 1955, na cidade de Kassel, na Alemanha.

Retratos de uma trajetória: Pibid/UCS - 2014 a 2018 
exposição de modo apátrido, dessexualizado, descolorizado e descolonizado permite que novas narrativas se construam em meio à história oficial e universal da arte. Pensar as obras como apátridas, dessexualizadas, descolorizadas e descolonizadas não faz com que as obras sejam descontextualizadas em seus sentidos, mas faz com que as normas não regulem o que entra na narrativa oficial da exposição. As subjetividades vinculadas à nacionalidade, à sexualidade e à raça continuam presentes e servem como modos de interpretação e significação conceitual.

Neste sentido, vê-se que a produção artística não hegemônica tem aparecido com frequência nas exposições de grande alcance. Isso fortalece a necessidade de explorar as narrativas omitidas nas grades curriculares da Educação Básica e do Ensino Superior, que se posicionam como um discurso oficial e universal. Ao inserir na escola o conhecimento da arte latino-americana, pretende-se utilizar os eventos artísticos como motivadores, para orientar o desenvolvimento de novos conhecimentos aos estudantes. Deste modo, os estudantes serão orientados a escrever e refletir sobre a produção artística, buscando desenvolver o senso crítico e a autonomia.

Tratar a arte latino-americana no contexto escolar permitiria aos/às estudantes brasileiros/as o conhecimento da sociedade e da cultura dos países da América Latina, tendo, provavelmente, maior interesse dos estudantes o conhecimento das produções nacionais e dos países vizinhos. A arte latinoamericana descreve, por meio da imagem, bem a realidade desses países, que muitas vezes são diferentes da realidade abordada nas obras estado-unidenses ou europeias. Assim, estudando a arte latino-americana, provavelmente, os estudantes se sentirão inseridos no contexto na qual ela foi realizada.

O simples ato de estudar somente as obras da Europa, dos EUA e do Brasil faz com que se desconheça as produções dos países latino-americanos, privilegiando, principalmente, a cultura norte-americana. É fato que o Brasil, mais do que outros países latino-americanos, volta-se mais àquilo que é produzido no Hemisfério Norte-Ocidental (AMARAL, 2006), basta observar os costumes, os filmes na televisão, as músicas nas rádios. Raramente passam filmes latinos em canais abertos e raramente tocam músicas latinas nas rádios. Essa segregação é um dos fatores que desvaloriza a arte latino-americana. Por isso é preciso valorizar a cultura latino-americana, é importante que os 
estudantes da Educação Básica possam estudá-la e teorizar sobre suas expressões linguísticas e artísticas. Precisa-se repensar a educação de Arte, buscando reescrever a história da arte, refletindo e aprendendo sobre as diferentes culturas artísticas, entre elas a arte latino-americana que pode, em longo prazo, ganhar espaço nas grades curriculares do Ensino Básico e Superior.

A inserção dessa cultura será um desafio aos professores, pois há pouca bibliografia sobre arte latino-americana própria para os estudantes da Educação Básica. Há uma carência de estudos, sobretudo no contexto escolar, tornando-se assim um tema relevante e inovador para pesquisas educacionais.

Diante desse cenário, cabe ao professor de Arte buscar algumas estratégias para tratar do tema, principalmente por meio de um estudo interdisciplinar, pois é possível abordar a arte latino-americana mostrando mapas para contextualizar seus territórios; identificando os países que compõem a América Latina; abordando costumes e tradições, relacionando-os, a fim de identificar similaridades e diferenças entre países latino-americanos e estrangeiros; discutindo sobre as obras, analisando elementos pictóricos, que trazem a identidade latino-americana - símbolos latinos que dão significado às obras; enfim, contextualizar esse continente que, apesar de ser onde os estudantes vivem, provavelmente, pouco o conhecem. A leitura das obras de arte permite o desenvolvimento de todos esses aspectos, pois instiga os estudantes a relacionarem as obras com o contexto histórico, cultural, econômico, político e religioso do país e até mesmo do continente. São inúmeras as obras de arte que podem ser abordadas, para que os estudantes conheçam a vasta produção latino-americana e compreendam como varia o suporte artístico. Importante é destacar que a leitura de imagem fará com que o estudante desenvolva seu pensamento estético e o pensamento crítico acerca de obras de arte.

Conclui-se que o componente curricular Arte está desconsiderando o que é produzido na América Latina, com exceção da arte brasileira. A experiência oportunizada pelo Pibid/Artes Plásticas e Visuais da Universidade de Caxias do Sul mostrou a necessidade e a importância de construir uma nova narrativa sobre a história latino-americana, para que esteja presente na Educação Básica, pois os estudantes têm o direito de conhecer a vasta produção artística do continente latino-americano, ao lado da história da arte hegemônica, cuja presença é privilegiada na escola. Ao abordar e contextualizar outras narrativas 
da arte, no Ensino Básico, surgirão leituras mais ricas e plurais, desenvolvendo o processo de significação e de compreensão da arte e da realidade.

\section{Referências}

ALBERDI, Juan Bautista. Ideas para un curso de filosofía contemporánea. Ideas en torno de Latinoamerica. México: Unam I, 1986. v. 2

AMARAL, Aracy Abreu. Textos do Trópico de Capricórnio: artigos e ensaios (1980-2005). Circuitos de arte na América Latina e no Brasil. São Paulo: Editora 34, 2006. v. 2.

ALIAGA, Juan Vicente. Relatos desconformes: teoria queer, política e arte em um mundo pós-colonial. In: GERALDO, Sheila Cabo; RIBEIRO, Marta; SIMÃO, Luciano Vinhosa (Ed.). Poiésis, Niterói, n. 15, p. 15-24, jul. 2010.

ARNOLD, Dana. Art history: a very short introduction. Oxford: Oxford, 2004.

BOONE, Silvana; SELISTRE, Jacks Ricardo. O lugar da arte latino-americana no século XXI. In: ENCONTRO DE HISTÓRIA DA ARTE, 6., Campinas. Anais... Campinas: 2016, p. 531537. Disponível em: <http://www.unicamp.br/chaa/eha/atas/2015/Silvana\%20Boone\%20e\%20Jacks\%20Rica rdo\%20Selistre.pdf>.

BOURDIEU, Pierre; DARBEL, Alain. Obras culturais e disposição culta. In: BOURDIEU, Pierre; DARBEL, Alain. $\mathbf{O}$ amor pela arte: os museus de arte na Europa e seu público. Porto Alegre: Zouk, 2007.

BLANCA, Rosa María. Exposições queer: contextos mundiais e locais. Cadernos de Gênero e Diversidade, v. 3, n. 3, 2017.

CRIMP, Douglas. Estudos culturais, cultura visual. Revista USP, São Paulo, n. 40, p. 78-85, dez./fev. 1998.

ECO, Umberto. A obra aberta. São Paulo: Perspectiva, 2013.

FOUCAULT, Michel. Microfísica do poder. Rio de Janeiro: Paz e Terra, 2016.

LOPONTE, Luciana Gruppelli. Sexualidades, artes visuais e poder: pedagogias visuais do feminino. Estudos feministas, Florianópolis, v. 10, n. 2, p. 283-300, 2002, jul./dez. 2002.

LOURO, Guacira Lopes. Um corpo estranho: ensaios sobre sexualidade e teoria queer. Belo Horizonte: Autêntica, 2004.

GARCIA, Hudinilson. Homoerotismo e imagem no Brasil. São Paulo: Fapesp, 2004. 
MISKOLCI, Richard. Teoria queer: um aprendizado pelas diferenças. Belo Horizonte: Autêntica, 2012.

ROSSI, Maria Helena Wagner. Imagens que falam: leitura da arte na escola. Porto Alegre: Mediação, 2011.

SCOTT, Joan W. O enigma da igualdade. Revista Estudos Femeministas, Florianópolis, v. 13, n. 1, p. 11-30, abr. 2005. 


\title{
2 \\ ARTE CONCEITUAL NO PROCESSO DE DESENVOLVIMENTO ESTÉTICO DE ADOLESCENTES
}

\author{
Bruna Scherner da Silva \\ bruscherner@gmail.com \\ Subprojeto Artes Plásticas e Visuais* \\ Escola Municipal de Ensino Fundamental Caldas Júnior
}

\begin{abstract}
Resumo: $\mathrm{O}$ artigo trata de um projeto de desenvolvimento do pensamento estético por meio do estudo da Arte Moderna e da Arte Conceitual, desenvolvido em uma turma de 8 o ano, com estudantes cuja faixa etária média é 13 anos. A escolha do tema para esse projeto foi feita por meio de sondagem com os estudantes. As aulas foram desenvolvidas por meio de discussão em grande grupo, contextualização histórica da arte e sequências didáticas referentes à Arte Conceitual, com a criação de uma proposta de propaganda, um relicário e um livro de artista.

Palavras-chave: Arte como linguagem. Arte contemporânea. Arte conceitual e processos criativos.
\end{abstract}

\section{Introdução}

Este artigo aborda um projeto que focou a introdução da arte conceitual na formação do pensamento estético, desenvolvido no programa de iniciação à docência - Pibid Artes Plásticas e Visuais na EMEF Caldas Júnior, em Caxias do Sul/ RS.

Para dar início ao projeto, realizei um levantamento inicial com o intuito de identificar características do pensamento estético dos estudantes. Não surpreendentemente, os alunos apresentaram um distanciamento significativo da arte como conceito. Assim, considerei importante possibilitar meios para o desenvolvimento estético dos alunos, utilizando as vanguardas artísticas como conteúdo e utilizando a Abordagem Triangular como procedimento.

O projeto foi realizado com o auxílio da professora de Arte. A partir de seu consentimento foram iniciadas aulas teórico-práticas contextualizando desde as vanguardas do início do século XX até a arte conceitual.

Os alunos foram instigados a produzir e a refletir sobre cada movimento artístico por meio da contextualização histórica, um dos elementos da

\footnotetext{
"Coordenadora do subprojeto: Profa. Dra. Maria Helena Wagner Rossi. Supervisora: Profạ. Rosebel Rech.
} 
Abordagem Triangular. A Arte Conceitual foi apresentada por meio de aulas teóricas e sequências didáticas.

Assim, o objetivo geral do projeto foi a ampliação do desenvolvimento estético dos alunos.

\section{Das vanguardas à arte conceitual}

Visando a facilitar a compreensão da arte como conceito e considerando os conhecimentos prévios dos alunos, decidi apresentar as vanguardas do século XX - que foram indispensáveis para o rompimento com paradigmas tradicionais da arte. Também foi apresentada a Arte Conceitual. As vanguardas apresentadas foram: Expressionismo, Cubismo, Dadaísmo, Surrealismo e uma artista contemporânea brasileira - Lygia Clark.

O primeiro movimento a ser apresentado foi o Expressionismo, surgido na Alemanha no início do século XX. Para Gombrich (p. 564), "o que perturba e deixa perplexo o público em relação à arte expressionista talvez seja menos o fato de a natureza ser distorcida do que o resultado implicar um distanciamento da beleza".

Ao abordar esse conteúdo ficou evidente que as ideias estéticas dos alunos, prioritariamente, eram de Nível I, na classificação de Rossi (2003), pois os alunos descreveram de modo concreto as imagens. Algumas falas foram: Ele está muito triste, As pessoas parecem doentes.

Ao julgarem as imagens, surgiram juízos negativos, ao lerem imagens expressionistas com temas tristes ou cores escuras. A respeito do julgamento estético no nível I Rossi diz:

Assim, quem define a qualidade da obra/imagem são os atributos do mundo, os quais são transferidos para ela. Para esse tipo de julgamento são usados os critérios: cor, tema, realismo, maestria do artista e utilidade da obra. No nível I, não há distinção entre julgamento moral e estético, com fusão dos termos bom/belo e ruim/feio. (2003).

Após as leituras das imagens, foi realizado um trabalho de produção. Aqui estão alguns trabalhos dos alunos. 


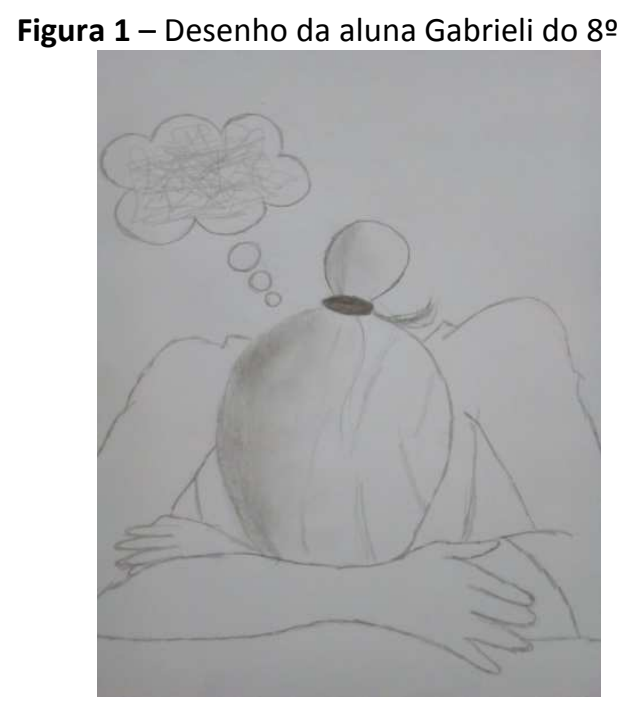

Fonte: Acervo da autora.

A seguir foi apresentado o Cubismo. Para abordar o Cubismo, foi feita uma contextualização sobre Picasso e proposta aos alunos a realização de um desenho, a partir de observação de objetos. O objetivo era representar o objeto em um desenho, mostrando suas diversas faces, segundo os princípios do Cubismo. Os alunos não se interessaram por esse conteúdo, declarando: $O$ desenho ficou feio, Nossa! Ficou horrível, não parece uma boneca. O intuito era que os alunos percebessem o desenho de modo a se diferenciar do tradicional, que eles classificam como o bom desenho bonito. No entanto, esse objetivo não foi alcançado, pois eles ainda valorizam o Realismo, nas representações artísticas, o que está de acordo com o nível I do pensamento estético.

O Dadaísmo foi o terceiro movimento a ser apresentado para a turma. Foram apresentadas características específicas e artistas que fizeram parte do movimento. Neste primeiro momento, a turma mostrou-se espantada com a linguagem dadaísta, pelo fato de não utilizar os suportes convencionais da arte. Alguns suportes da obra dadaísta são: objetos, fotografias, colagem, entre outros.

Após discussões sobre o Dadaísmo, os alunos foram instigados a criar um trabalho plástico segundo os princípios dadaístas, em recorte e colagem. Os alunos escolheram temas como: machismo, feminismo, política, corrupção, guerra na Síria e viagens pelo Brasil. A escolha dos temas, a produção do trabalho e a discussão em sala me surpreenderam positivamente. 
O quarto movimento apresentado foi o Surrealismo, termo "cunhado em 1924 a fim de expressar o anseio dos jovens artistas de criarem algo mais real do que a própria realidade, quer dizer, algo de maior significado do que a mera cópia daquilo que vemos". (GOMBrich, p. 409). O autor diz também que os surrealistas ficaram altamente impressionados com os escritos de Sigmund Freud, os quais demonstraram que, quando os nossos pensamentos em estado de vigília são entorpecidos, a criança e o selvagem que existem em nós passam a dominar.

Para esse movimento foi levado para a aula a animação* de Dalí em parceria com Walt Disney. Após a visualização da animação, os alunos se mostraram ainda mais confusos do que na aula anterior, quando abordamos o Dadaísmo. Foram trazidos também em discussão os signos na Semiótica, de forma mais subjetiva, a partir de outra animação, na qual não havia falas. Questionei os alunos sobre o entendimento referente ao vídeo assistido. Os alunos não souberam responder sobre do que se tratava, apenas elementos concretos como: Havia um monstro, Tinha um garoto que parecia triste, Era meio escuro, o que caracteriza um pensamento estético de Nível I. Acreditar que a arte é uma cópia do mundo é característico do pensamento estético de Nível I. (RossI, 2003).

Quanto ao Surrealismo, foi pedido aos alunos que realizassem uma pesquisa, com base em livros, sobre artistas surrealistas. Os artistas escolhidos foram: Salvador Dalí, Frida Kahlo, Juan Miró, René Magritte e Giorgio De Chirico.

Os alunos formaram grupos de cinco integrantes. A tarefa foi elaborar um resumo sobre vida e obra do artista escolhido e a seleção de três obras que mais Ihes interessavam. Ao indagar os alunos sobre suas opiniões sobre o trabalho, foi surpreendente o fato de nunca terem feito pesquisa sobre artistas. Todos mostraram-se contentes com o resultado de seus trabalhos. Uma curiosidade foi que o Surrealismo foi apontado pelos alunos na avaliação como o movimento preferido dentre todos, o que ficou claro na produção plástica sobre o Surrealismo, na qual desenharam seus sonhos.

O quinto assunto a ser tratado foi Lygia Clark, uma artista contemporânea brasileira, que utiliza características abstracionistas em seu trabalho. A obra utilizada como referência foi "Os Bichos", composta por placas de metal articuladas, que permitia ao público alterar sua forma. Foi proposto aos alunos 
que, com uma folha, criassem com recortes "seus bichos", com o mesmo princípio da obra.

Os alunos sentiram-se entusiasmados ao realizarem a produção artística, mas, durante a aula, surgiram opiniões de senso-comum, nas indagações feitas como: O que lembra vocês a palavra "Abstracionismo"? As respostas foram: Professora, não são aqueles quadros de gente rica? Não são aqueles rabiscos?. Com a realização deste trabalho, os alunos puderam conhecer o de uma artista brasileira e trabalhar com outros formatos de arte, ampliando seus conhecimentos sobre suportes artísticos.

Por último foi apresentada a Pop Art:

A Pop Art começou, na realidade em Londres, nos meados da década de 1950, mas desde o início as suas imagens foram extensamente baseadas nos meios de comunicação social norte-americanos, que vinham inundando a Inglaterra desde o fim da Segunda Guerra Mundial. (JANSON, 2001, p. 983).

Os alunos se entusiasmaram com o estudo da Pop Art, pelo fato de utilizar muitas cores nas obras. Também foi proposta uma produção artística aos alunos, que consistia em trabalhar sobre imagens de revistas, aproximando-se dos princípios da Pop Art, no que se refere à aproximação com a mídia impressa. Aqui estão alguns exemplos:

Figura 2 - Trabalho da aluna Bianca

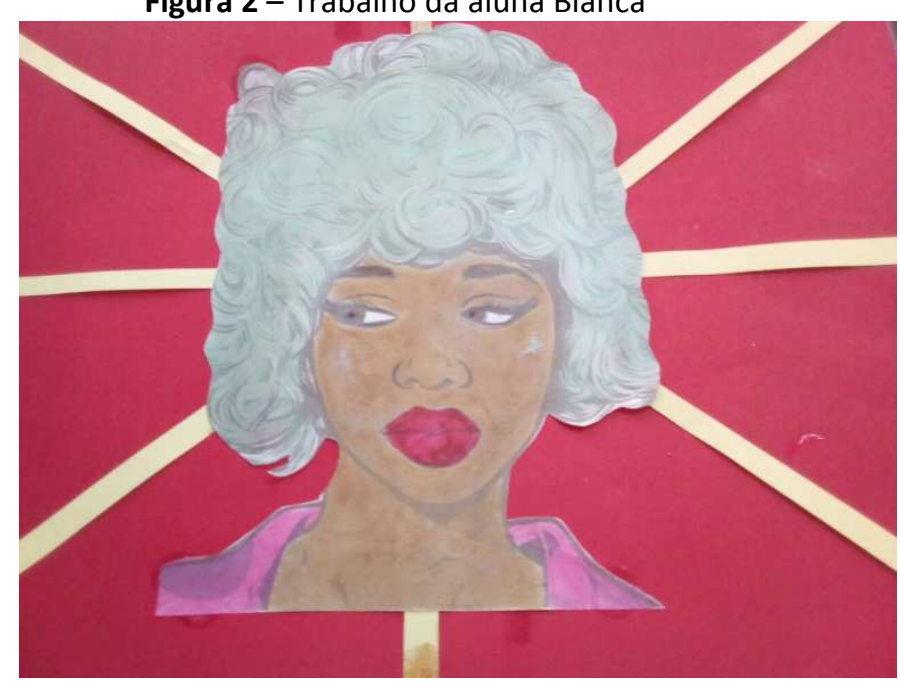

Fonte: Acervo da autora. 


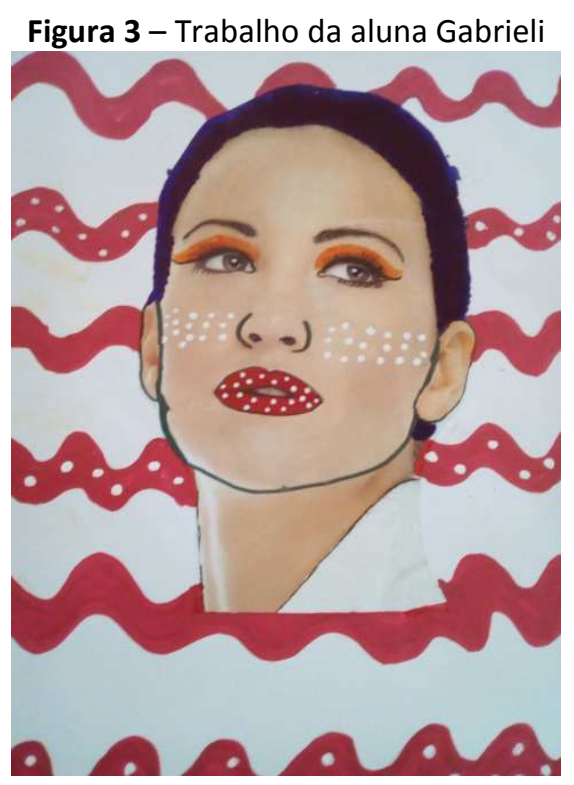

Fonte: Acervo da autora.

As vanguardas, o Abstracionismo e a Pop Art foram conteúdos trabalhados para ampliar a compreensão estética dos alunos. A partir desses conteúdos, os alunos puderam questionar sobre o que é arte, superando aquelas ideias mais ingênuas, reveladas no levantamento inicial, construindo assim um pensamento mais sofisticado a respeito da Arte. Algumas respostas interessantes surgidas na avaliação da disciplina foram: É a primeira vez que eu tenho aula de artes assim, então ainda estou me acostumando em ter que estudar artes, já que antes eu só fazia desenho na aula. São bem interessantes, bem diferente do que eu já estudei. Estou começando a entender um pouco.

Essas respostas mostram o estranhamento dos alunos com o fato de receberem aulas teóricas de arte e demonstram que houve uma aprendizagem significativa e, ainda, o desenvolvimento de seu pensamento estético.

\section{Arte conceitual na escola}

Arte Conceitual é um tema ainda pouco apresentado em sala de aula. Pude perceber isso quando iniciei as aulas que abordaram o conceito de arte, e os alunos mostraram-se distantes desse assunto.

As aulas, em sua maioria, foram diálogos em grande grupo, em que os alunos puderam construir conhecimentos com a troca de ideias. 
A Arte Conceitual foi apresentada durante as realizações das sequências didáticas e aulas teóricas. Foi proposta aos alunos a leitura de textos sobre Arte Conceitual, para que pudessem entender o significado de conceito de arte, para além da materialidade do fazer artístico.

As aulas práticas foram desenvolvidas por meio da construção do relicário da turma e do livro de artista, em que os alunos, além de executarem um trabalho prático, tiveram que formular um conceito para seus trabalhos.

Também foi proposto aos alunos que, a partir de recortes de revista, fizessem uma propaganda sem utilizar escrita. A atividade da propaganda serviu para ajudar na interpretação de imagens.

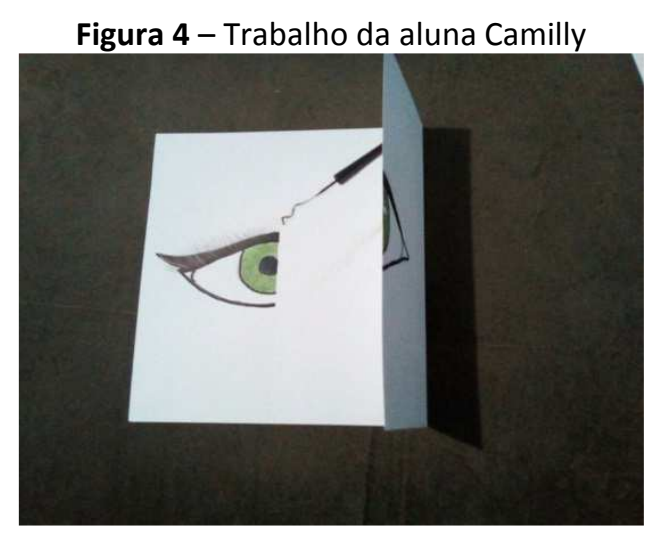

Fonte: Acervo da autora.

A construção do Livro de Artista foi o trabalho final da turma. Foi solicitado a cada aluno a escolha de uma palavra que os definisse. A partir dessa palavra, eles construíram um livro artístico autobiográfico. A apresentação dos trabalhos foi uma conversa em grande grupo, em que cada aluno poderia mostrar e falar sobre seu trabalho. Os alunos construíram trabalhos com qualidade e sentiramse entusiasmados com a realização da atividade. 
Figura 5 - Trabalho da aluna Gabriela

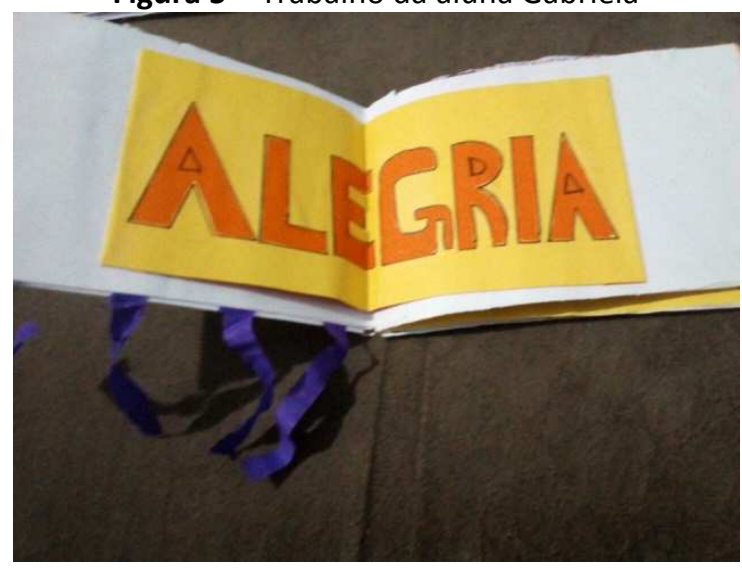

Fonte: Acervo da autora.

Figura 6 - Trabalho da aluna Bianca

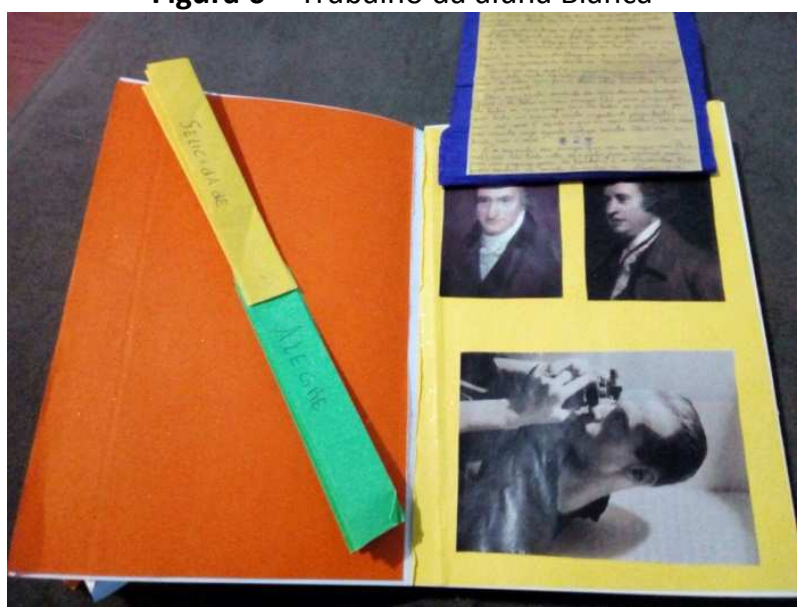

Fonte: Acervo da autora.

\section{Considerações finais}

Esse projeto teve como objetivo ampliar o pensamento estético dos alunos e seus conhecimentos em artes, bem como desenvolver habilidades técnicas.

A utilização das vanguardas serviu como meio de ampliar o desenvolvimento estético e o senso crítico dos alunos, com as leituras das imagens das obras. As sequências didáticas serviram para ampliar os conhecimentos dos alunos, referentes a suportes na arte e conhecerem a Arte Conceitual.

A construção de conhecimentos pelos alunos pode ser percebida em seus argumentos durante discussões realizadas em aula, como, por exemplo, em um 
comentário do aluno Gianluca: Profe, nós podemos olhar para uma obra e ter nossa própria interpretação. As discussões em aula serviram como propulsor para o desenvolvimento estético e, notavelmente, surgiram resultados.

\section{Referências}

BARBOSA, Ana Mae. Tópicos utópicos. Belo Horizonte: C/Arte, 1998.

BARBOSA, Ana Mae. Arte-educação: leitura no subsolo. 3. ed. São Paulo: Cortez, 2001.

GOMBRICH, Ernst. A história da arte. Rio de Janeiro: LTC, 1950.

JANSON, Horst Waldemar. História geral da arte. São Paulo: M. Fontes, 2001.

ROSSI, Maria Helena Wagner. Imagens que falam: leitura da arte na escola. Porto Alegre: Mediação, 2003. 


\title{
COMPOSIÇÃO VISUAL COMO MEIO PARA UM FAZER ARTÍSTICO CONSCIENTE NA ESCOLA
}

\author{
Anelise de Oliveira Müller \\ anedeoliveiraa@gmail.com \\ Ketlim Favero Machado \\ kfmachado@ucs.br \\ Subprojeto Artes Plásticas e Visuais* \\ Escola Municipal de Ensino Fundamental Caldas Júnior
}

Resumo: O artigo aborda a experiência realizada no Pibid no subprojeto de Artes Visuais da Universidade de Caxias do Sul (RS). O projeto, desenvolvido em uma escola municipal, com uma turma do $6^{\circ}$ ano, teve o intuito de privilegiar um fazer artístico consciente, qualificando as possibilidades de expressão de ideias, por meio das produções artísticas dos estudantes. Para isso, pensamos em uma prática na qual os alunos pudessem produzir e ler imagens da arte de modo mais consciente e reflexivo. Como meio, utilizamos o conteúdo "composição visual". Propomos, inicialmente, a leitura formal de imagens para, então, desenvolver leituras que ampliassem a compreensão estética dos estudantes. Valorizando a experiência cotidiana dos alunos e considerando os relatos de discriminação e bullying sofridos na escola, sugerimos o tema "identidade e preconceito". A intenção era que eles percebessem como suas experiências têm significado e são fontes para dar sentido ao mundo, em especial, por meio da arte. Aliando "composição visual" e "identidade e preconceito", o projeto se concretizou por meio de leituras de imagens, contextualização e produção artística, seguindo os pressupostos da Abordagem Triangular para o ensino da arte. Percebemos que é possível trabalhar aspectos formais da arte de modo que os estudantes concebam a arte como uma linguagem que lhes permite explicitar e comunicar ideias e, ainda, ampliar suas habilidades para ler imagens, seja da arte ou do cotidiano.

Palavras-chave: Arte no Ensino Fundamental. Intencionalidade na produção artística. Composição visual. Preconceito. Identidade.

\section{Introdução}

Este artigo aborda experiência realizada em 2017, no Programa Institucional de Bolsa de Iniciação à Docência (Pibid), no subprojeto Artes Visuais, da Universidade de Caxias do Sul, na Escola Municipal de Ensino Fundamental Caldas Júnior, em Caxias do Sul (RS).

A escola está localizada no Bairro Petrópolis, região nobre da cidade. É uma instituição de pequeno porte, com dez salas de aula, onde atuam 48 professores,

* Coordenadora do subprojeto: Profa. Dra. Maria Helena Wagner Rossi. Supervisora: Profa. Rosebel Rech. 
sendo dois do componente curricular Arte. Os estudantes provêm de diferentes bairros da cidade, sendo poucos os que residem nas imediações da escola.

Para desenvolvermos o projeto, inicialmente fizemos uma observação diagnóstica, visando a conhecer aspectos cognitivos e socioculturais dos estudantes, características dos seus processos de aprendizagem e suas concepções sobre arte. Assim, acompanhamos durante algumas semanas a turma 62 do $6^{\circ}$ ano, com 26 alunos entre 11 e 14 anos.

Observamos que, nas apresentações de trabalhos solicitados pela professora de Arte, ou quando se comunicam entre si na realização de atividades, as justificativas sobre escolhas eram sempre intuitivas; a disposição das imagens na folha de papel era aleatória; utilizavam imagens de referência estereotipadas; as cores eram escolhidas por preferências pessoais; as texturas e linhas eram definidas sem a preocupação sobre o que poderiam comunicar... Além disso, identificamos que suas concepções sobre arte abarcavam apenas as linguagens do desenho e da pintura, especificamente quadros em residências e museus.

Dessa forma, apesar de estudarem a composição visual, não sabiam como utilizá-la como meio de comunicação de ideias. Martins, Picosque e Guerra afirmam que "só aprendemos aquilo que, na nossa experiência, se torna significativo para nós. Nessa perspectiva, ensinar [...] é possibilitar que o outro construa sentidos". (1998, p. 128-129). Vasconcellos (2004) corrobora essa ideia, dizendo que para uma educação significativa é preciso que a atividade tenha relevância para o educando. Para esse autor, o aluno precisa sentir necessidade de aprender, assim, a ação educativa deve ter um sentido "de provocar, desafiar, estimular, ajudar o sujeito a estabelecer uma relação pertinente com o objeto, que corresponda, em algum nível, à satisfação de uma necessidade sua". (VASCONCELLOS, 2004, p. 63).

Ainda durante as observações, houve relatos de situações que revelam preconceitos entre os próprios colegas, como piadas de mau-gosto e apelidos cruéis, relacionados às suas características e seus modos de ser. Em vista disso, buscando aliar o ensino da arte à experiência cotidiana dos alunos, escolhemos o tema "identidade e preconceito", no desenvolvimento deste trabalho. Barbosa, mencionando Homi Bhabha, afirma que a identidade assegura a representação 
do sujeito, diferenciado do outro, ou seja, a identidade é encontrada nas diferenças:

A função das artes na formação da imagem da identidade lhe confere um papel característico dentre os complexos aspectos da cultura. Identificação é sempre a produção de "uma imagem de identidade e transformação do sujeito ao assumir ou rejeitar aquela imagem reconhecida pelo outro". (BARBOSA, 1998, p. 15-16).

Nesse sentido, o intuito é transformar os conflitos em conhecimento sobre o outro. Segundo Guzmán, desse modo, "o conhecimento deixa de ser uma relação entre sujeitos e objeto para converter-se em uma relação entre sujeitos, entre pessoas". (apud CAO, 2005, p. 189). O aluno deve entender que suas experiências pessoais têm significado e são fontes para dar sentido ao mundo. Assim, percebem que suas histórias ajudam a construir o conhecimento, completa Cao (2005).

Pensando em uma prática significativa, na qual os alunos pudessem produzir e ler a arte de modo consciente, considerando-a como linguagem que os possibilita pensar, elaborar, questionar e expressar problemáticas e ideias que Ihes inquietam, a proposta aliou a composição visual ao tema "identidade e preconceito".

\section{Composição visual nas aulas de Arte}

A composição visual é conteúdo previsto nos Planos de Trabalho da Secretaria Municipal de Educação do Município de Caxias do Sul (RS). Wong (2010) afirma que é fundamental desenvolver uma abordagem intelectual em relação à linguagem visual na escola, visando a compreender como os elementos visuais podem transmitir mensagens. O aluno poderá, dessa forma, definir quais elementos visuais utilizará, de acordo com a sua intenção.

Porém, a tendência formalista de leitura de imagem é comum no ambiente escolar. Segundo Sardelich (2006, p. 454), o livro de Donis Dondis, A primer of visual literacy, de 1973, fundamentou essa prática nas escolas:

[...] apoiando-se no sistema proposto por Dondis para uma "alfabetização visual", alguns professores começaram a aplicar um esquema de leitura de imagens fundamentado na sintaxe visual, que mostra a disposição dos elementos básicos, como ponto, linha, forma, cor, luz, no sentido da composição. (SARDELICH, 2006, p. 454). 
Hernández (2000) explica que dar prioridade aos elementos formais acentua a importância às qualidades externas e materiais das imagens, deixando de lado aspectos simbólicos, o que, para o autor, limitaria as possibilidades de compreensão das artes visuais. Além disso, Rossi ressalta a inadequação dessa prática que, não considerando a natureza do pensamento estético dos estudantes, não oportuniza ao aluno a reflexão sobre a arte:

O enfoque formalista de leitura estética, que, historicamente, vem sendo priorizado no ensino universitário de arte no Brasil, contaminou a Educação Básica. Frequentemente, a leitura estética tem se reduzido a um roteiro preestabelecido de perguntas que não respeitam a construção dos alunos nesse domínio, nem tampouco a natureza e a especificidade da imagem que está sendo analisada. (Rossı, 2009, p. 133).

Os elementos visuais transmitem informações sobre a estrutura da composição; já a leitura estética prioriza a atribuição de significados e a reflexão sobre arte e estética (ROSSI, 2009). Sobre isso, Arnheim (2005, p. 12) diz que, "parar ao nível da superfície, contudo, deixaria todo o empreendimento truncado e sem significado. Não há motivo para que as formas visuais se desassociem daquilo que nos dizem". Sendo assim, a análise formal não deve ser negligenciada, desde que seu enfoque seja propício à interpretação da obra, como explica Rossi:

A análise formal e a contextualização histórica começam a ser oportuna quando o leitor já admite a intencionalidade do artista na produção da obra, considerando a arte como comunicação, que manifesta, transmite e gera significados; quando a ele importa se a obra tem uma mensagem, uma ideia, que o faça refletir sobre questões importantes da vida. (Rossı, 2008, p. 448449).

Não precisamos, de fato, eliminar a leitura formal, mas desenvolvê-la de modo a favorecer a atribuição de sentidos. Desse modo, o aluno poderá interpretar uma imagem, analisando tanto a sua estrutura formal quanto o seu significado, diferentemente das abordagens modernistas, que priorizavam apenas os aspectos formais na leitura de imagens. 


\section{Identidade, diferenças e o ensino da arte}

Nossa identidade é sempre desenvolvida pela presença do outro, pela aceitação ou rejeição de sua visão sobre nós; o tempo todo recebemos influências de diversas pessoas e ambientes, que nos tornam quem somos:

Numa abordagem antropológica, a identidade é uma construção que se faz com atributos culturais, isto é, ela se caracteriza pelo conjunto de elementos culturais adquiridos pelo indivíduo, através da herança cultural. A identidade confere a diferença aos grupos humanos. (TEDESCHI, 2008, p. 129).

As diferenças, que parecem se acentuar no ambiente escolar, se transformam em uma base para a discriminação e o bullying. Tedeschi (2008) diz que as identidades, seja de gênero, raça, étnica, etc., não se findam e estão em constante construção, sendo afetadas pelos mecanismos de inclusão e exclusão, atribuindo diferentes valores aos grupos.

Como professores devemos estar atentos a esses mecanismos, propiciando reflexões que estimulem o reconhecimento das subjetividades. Uma educação voltada para o respeito pressupõe não homogeneizar os alunos, mas dar voz e valorizar os diversos indivíduos nas suas particularidades:

Por isso, trabalhar as diferenças é um desafio para o professor, por ele ser o mediador do conhecimento, ou melhor, um facilitador do processo ensino e aprendizagem. A escola em que ele foi formado e na qual trabalha é reprodutora do conhecimento culturalmente elitizado, que dita as regras e determina o que deve ser transmitido aos alunos. Mas, se o professor for detentor de um saber crítico, poderá questionar esses valores e saberá extrair desse conhecimento o que ele tem de valor universal. (TEDESCHI, 2008, p. 131).

Muitas vezes o preconceito advém de um desconhecimento e distanciamento sobre o outro. O ensino da Arte, em especial por ser uma linguagem com códigos específicos, favorece o diálogo entre as subjetividades. Barbosa (1998) destaca o papel da arte, em especial a visual, que, por meio das imagens, torna perceptível quem somos e como nos sentimos. A arte na educação favorece a expressão pessoal e cultural, além de possibilitar o desenvolvimento dos alunos, ampliando sua capacidade crítica para analisar, refletir e modificar a realidade. 


\section{Desenvolvimento do projeto}

O projeto foi realizado de março a dezembro de 2017 e teve o objetivo de proporcionar ao aluno condições de produzir e ler arte de modo consciente, qualificando os estudantes a expressarem ideias em suas produções artísticas.

O conteúdo "composição visual" já estava sendo trabalhado pela turma, antes da concepção do projeto; porém, os alunos não conseguiam dar sentido às suas produções e utilizavam os elementos da composição ao acaso. Diante disso, continuamos explorando e revisando o assunto, para que os estudantes pudessem elaborar trabalhos com maior intencionalidade e consciência.

Com base nas observações, valorizamos algo que o ensino escolar por vezes negligencia - a alfabetização visual -, elemento importante para que o aluno se expresse e leia a imagem criada pelo outro, tanto na escola como nos meios de comunicação de massa. Além disso, na assembleia de classe, ${ }^{1}$ alguns alunos manifestaram incômodo com discriminações que sofriam, através de palavras e apelidos referentes à sua personalidade ou características físicas. Desse modo, o projeto visou, também, a promover uma reflexão sobre questões de diferença. A proposta, assim, relaciona a "composição visual" ao tema "identidade e preconceito".

Inicialmente, com o intuito de construir um conhecimento abrangente sobre composição visual, foram apresentadas imagens de obras de arte, arquitetura e publicidade aos estudantes, propondo, uma leitura formal de imagem. As imagens levaram em conta, também, o tema do projeto. Barbosa elucida que a expressão "leitura de obra de arte" utilizada na Abordagem Triangular para o ensino da Arte, foi inspirado no movimento de ensino de literatura americana Reader Response, o qual "não despreza os elementos formais, mas não os prioriza", levando em conta aspectos emocionais e pessoais na leitura. (BARBOSA, 1995, p. 62).

Como condição para proporcionar uma aprendizagem significativa por meio de leitura de imagens, se faz necessária a identificação do nível de compreensão estética dos alunos. Em vista disso, foram priorizadas as análises

\footnotetext{
${ }^{1}$ Assembleia de classe é uma reunião entre alunos, mediada pela professora conselheira, quando são avaliados os pontos positivos e negativos de convivência e aprendizagem.
} 
da interpretação e do julgamento das imagens feitos pelos estudantes. De acordo com Parsons:

Na modernidade, a ênfase era na percepção [...], mas hoje precisamos perguntar, não como as crianças veem as coisas, mas qual o significado que atribuem a elas. Quais são as capacidades interpretativas que elas têm e como elas compreendem arte? (Apud RossI, 2009, p. 20).

Levando em conta os dois períodos semanais das aulas de Arte, em um deles era realizada a leitura e a contextualização das imagens, juntamente com a conceituação de um dos elementos da composição visual nelas presentes. Já na aula seguinte, os alunos produziam seus trabalhos, utilizando o elemento estudado na aula anterior. Durante a leitura das imagens, os alunos apresentaram interpretações ingênuas em relação a elas, ou seja, não transcendiam os elementos concretamente representados. No entanto, isso se modificou ao longo do processo, quando passaram a interpretar ideias e mensagens, no que lhes era apresentado.

Quanto às produções, os alunos foram orientados a pensar no que gostariam de comunicar, antes de escolher a cor ou a linha, por exemplo, que iriam utilizar. A maioria dos trabalhos foi apresentada para a turma com a justificativa das escolhas. Conforme trabalhavam com atribuição de significados às suas próprias produções e faziam as leituras de imagens, demonstravam ideias mais complexas e maduras nas suas leituras estéticas, ou seja, buscavam mensagens, valorizando a expressividade da imagem. Essa mudança é coerente com o que diz Rossi sobre o desenvolvimento de ideias mais abrangentes na leitura estética:

As construções no domínio da leitura estética dependem de inúmeras variáveis, que atuam na interação do sujeito com seu meio. Provavelmente não haverá o desenvolvimento das ideias mais sofisticadas e autônomas em meios onde a discussão estética não é privilegiada. (Rossl, 2009, p. 130).

Para finalizar o projeto, os estudantes realizaram entrevistas para descobrir se as pessoas (voluntários) já haviam sofrido algum preconceito. Além disso, pesquisaram sobre artistas que abordaram essa temática em suas obras. Com 
base nisso, produziram colagens, desenhos, pinturas, esculturas e assemblages, ${ }^{2}$ empregando conceitos de composição visual e o tema "identidade e preconceito". A reunião dos trabalhos resultou na confecção de um fanzine, que foi distribuído na escola e na comunidade.

O projeto foi pensado a partir da Abordagem Triangular, elaborada por Ana Mae Barbosa, que prevê a inter-relação da leitura de obras de arte e imagens, a contextualização e a produção artística. Destacamos o papel da contextualização na construção de significados em nosso projeto. Segundo Barbosa:

\begin{abstract}
A contextualização é em si mesma forma de conhecimento relativizada. Pesquisas sobre cognição situada mostram que o conhecimento e o entendimento são mais facilmente efetivados se emoldurados pelo sujeito. É esta moldura que designamos contextualização, a qual pode ser subjetivamente e/ou socialmente construída. (BARBOSA, 1998, p. 38).
\end{abstract}

Esse pensamento é o que nos motivou a relacionar os conteúdos artísticos com experiências e vivências dos alunos.

\title{
Considerações finais
}

Neste projeto percebemos que é possível trabalhar com o conteúdo "composição visual" de modo a ultrapassar as barreiras do formalismo estético. O ensino e a prática exclusiva da leitura formalista não são suficientes para a construção do pensamento estético dos alunos.

Ao trabalhar a leitura crítica de imagens, pudemos problematizar as representações sociais e culturais, tanto na arte quanto nos meios de comunicação. No entanto, percebemos que apenas o contato com as imagens não é suficiente; sem a mediação estética, os estudantes pouco vão se interessar pelo que estão vendo.

Na prática, ao questionar os alunos sobre as imagens, de modo que thes permitissem construir sentidos, notamos que as interpretações e os julgamentos evoluíram para um pensamento estético mais sofisticado. Nas leituras em grupo, a exposição de uma ideia estética mais madura e complexa incentivava o

\footnotetext{
${ }^{2}$ Assemblage é o termo para definir colagens ou composições artísticas feitas com objetos ou materiais tridimensionais.
} 
restante da turma à reflexão, o que, de certo modo, contribuiu para o desenvolvimento estético de outros estudantes.

Utilizar como tema algo que está presente na vida dos alunos permitiu que eles pudessem representar suas próprias experiências e situações vividas por outras pessoas. No final do projeto, já se preocupavam com a atribuição de sentidos, inclusive, questionando os colegas sobre os significados de suas produções e as escolhas feitas nas suas produções artísticas. Isso nos permite concluir que é possível proporcionar uma aprendizagem significativa utilizando uma abordagem que valoriza a atribuição de sentidos a um conteúdo de natureza formal, no caso, os elementos da composição visual.

O objetivo do projeto foi alcançado, no sentido de que os estudantes produziram e fizeram leituras da arte, de modo mais consciente e reflexivo, compreendendo-a como uma linguagem que lhes permitiu explicitar e comunicar ideias e a interpretar de modo mais maduro as imagens da arte e do seu cotidiano.

\section{Referências}

ARNHEIM, Rudolf. Arte e percepção visual: uma psicologia da visão criadora. São Paulo: Pioneira Thomson Learning, 2004.

AZEVEDO, Fernando Antônio Gonçalves de. A arte possibilita ao ser humano repensar suas certezas e reinventar seu cotidiano. In: BARBOSA, Ana Mae; COUTINHO, Rejane Galvão (Org.). Arte/educação como mediação cultural e social. São Paulo: Unesp, 2009.

BARBOSA, Ana Mae. Arte-educação pós-colonialista no Brasil: aprendizagem triangular. Comunicação e Educação, São Paulo, n. 2, p. 59-64, jan./abr. 1995. Disponível em: <https://www.revistas.usp.br/comueduc/article/viewFile/36136/38856>. Acesso em: 3 nov. 2017.

BARBOSA, Ana Mae. Tópicos utópicos. Belo Horizonte: C/Arte, 1998.

BARBOSA, Ana Mae. A imagem no ensino da arte. São Paulo: Perspectiva, 2002.

CAO, Marián López. Lugar do outro na Educação Artística - olhar como eixo articulador da experiência: uma proposta didática. In: BARBOSA, Ana Mae (Org.). Arte/educação contemporânea: consonâncias internacionais. São Paulo: Cortez, 2005.

HERNÁNDEZ, Fernando. Cultura visual, mudança educativa e projeto de trabalho. Porto Alegre: Artmed, 2000. 
MARTINS, Mirian Celeste; PICOSQUE, Gisa; GUERRA, Maria Terezinha Telles. Didática do ensino da arte: a língua do mundo: poetizar, fruir e conhecer arte. São Paulo: FDT, 1998.

ROSSI, Maria Helena Wagner. A leitura estético-visual no ensinar e aprender artes. In: ENDIPE. Trajetórias e Processos de ensinar e aprender: práticas e didáticas, 13., 2008, Porto Alegre. Anais... Porto Alegre: EdiPUCRS, 2008a, p. 445-458. v. 2.

ROSSI, Maria Helena Wagner. Imagens que falam: leitura da arte na escola. 4. ed. Porto alegre: Mediação, 2009.

SARDELICH, Maria Emilia. Leitura de imagens, cultura visual e prática educativa. Cad. Pesqui., Ago 2006, v. 36, n. 128, p. 451-472. ISSN 0100-1574. Disponível em:

<http://www.scielo.br/pdf/\%0D/cp/v36n128/v36n128a09.pdf>. Acesso em: 15 nov. 2017.

TEDESCHI, Losandro Antonio. Identidades, diferenças e pedagogias culturais na escola. In: DOTTI, Corina Michelon (Org.). Diversidade e inclusão: reconfiguração da prática pedagógica. Caxias do Sul: Educs, 2008.

VASCONCELLOS, Celso dos Santos. Construção do conhecimento em sala de aula. 15. ed. São Paulo: Libertad, 2004.

WONG, Wucius. Princípios de forma e desenho. São Paulo: M. Fontes, 2010. 


\title{
CONTRIBUIÇÕES E APRENDIZAGEM DOS SUJEITOS ENVOLVIDOS NO SUBPROJETO DE EDUCAÇÃO FÍSICA
}

\author{
Camila Carraro Poletto \\ cpoletto1@ucs.br \\ Lisiane Ambrosio Varella \\ lisyvarella@hotmail.com \\ Mestre Eliete Maria Scopel \\ emscopel@ucs.br \\ Subprojeto Educação Física
}

EEEM Professor José Fernandes de Oliveira

Resumo: Esta pesquisa tem por objetivo identificar as contribuições do "Programa Institucional de Bolsa de Iniciação à Docência" (Pibid), na construção de aprendizagem dos sujeitos envolvidos no subprojeto: "Redescobrindo a Educação Física nos Anos Iniciais do Ensino Fundamental". De acordo com a Portaria 096/2013, em seu art. 2o, o Pibid é um programa da Coordenação de Aperfeiçoamento de Pessoal de Nível Superior (Capes), que tem por finalidade fomentar a iniciação à docência e contribuir para o aperfeiçoamento da formação de docentes em nível superior e para a melhoria da qualidade da Educação Básica pública brasileira. Para a coleta de informações, utilizou a pesquisa descritivo-qualitativa e o instrumento questionário com dez perguntas abertas e fechadas, da qual participaram dez docentes dos Anos Iniciais do Ensino Fundamental da escola-parceira, cinco bolsistas que atuam no referido subprojeto e dezoito exbolsistas. Em virtude das indagações levantadas no início deste estudo, pode-se destacar que o Pibid tem sido fator relevante para a articulação entre teoria e prática necessária na formação inicial de docente, contribuindo, assim, para que os acadêmicos se insiram na cultura escolar, por meio de apropriação e reflexão sobre instrumentos, saberes e peculiaridades do trabalho docente e, dessa forma, elevando a qualidade das ações acadêmicas, dando-lhes mais segurança na prática dos estágios curriculares e na atuação no campo profissional.

Palavras-chave: Pibid. Educação Física. Iniciação à docência.

\section{Introdução}

O Programa Institucional de Bolsa de Iniciação a Docência (Pibid), de acordo com a Portaria 096/2013, ${ }^{1}$ é um programa da Coordenação de Aperfeiçoamento de Pessoal de Nível Superior (Capes), que tem por finalidade fomentar a iniciação à docência, contribuindo para o aperfeiçoamento da formação de docentes em nível superior e para a melhoria da qualidade da

\footnotetext{
${ }^{1}$ BRASIL. Portaria 096/2013. Regulamenta o Programa Institucional de Bolsa de Iniciação à Docência (Capes, 2013). Disponível em: <https://www.capes.gov.br/images/stories/download/legislacao/Portaria_096_18jul13>. Acesso em: 7 mar. 2017.
} 
Educação Básica pública brasileira, tendo como base legal a Lei 9.394/1996, ${ }^{2}$ que trata das Diretrizes e Bases da Educação Nacional; a Lei 12.796/2013, ${ }^{3}$ que estabelece as Diretrizes e Bases da Educação Nacional, para dispor sobre a formação dos profissionais da educação e dar outras providências; e o Decreto $7.219 / 2010,{ }^{4}$ que versa sobre o Pibid e dá outras providências.

$\mathrm{Na}$ Universidade de Caxias do Sul (UCS), o Pibid iniciou suas atividades no ano de 2013. Dessa forma, a UCS, com o intuito de realizar uma aproximação com as escolas de Educação Básica das redes pública, estadual e municipal, nos Municípios de Caxias do Sul, Bento Gonçalves e Vacaria, apresentou seu projeto institucional.

No Campus Universitário de Vacaria, foi direcionado o subprojeto "Redescobrindo a Educação Física nos Anos Iniciais do Ensino Fundamental", que tem a finalidade de possibilitar a inserção de acadêmicos do curso de Licenciatura em Educação Física da UCS - Campus Universitário de Vacaria, na Escola Estadual de Ensino Médio Professor José Fernandes de Oliveira, com o objetivo de conhecer sua realidade e redimensionar a situação atual da Educação Física, além de promover a interação dos universitários com os educadores da escola-parceira, possibilitando a construção da sua identidade docente.

Considerando que o Pibid é um programa voltado ao saber docente, este artigo apresenta os resultados de pesquisa, que integrou o Trabalho de Conclusão de Curso, que teve por objetivo identificar a contribuição do Pibid na construção de aprendizagem dos sujeitos envolvidos no subprojeto "Redescobrindo a Educação Física nos Anos Iniciais do Ensino Fundamental".

\footnotetext{
${ }^{2}$ BRASIL. Lei 9.394/1996. Lei de Diretrizes e Bases da Educação Nacional. Disponível em: <http://www.planalto.gov.br/>. Acesso em: 7 maio 2017.

${ }^{3}$ BRASIL. Lei 12.796/2013. Altera a Lei 9.394, de 20 de dezembro de 1996, que estabelece as diretrizes e bases da educação nacional, para dispor sobre a formação dos profissionais da educação e dar outras providências. Disponível em: <http://www.planalto.gov.br/ccivil_03/Ato2011-2014/2013/Lei/L12796.htm>. Acesso em: 7 maio 2017.

${ }^{4}$ BRASIL. Decreto 7.219/2010. Dispõe sobre o Programa Institucional de Bolsa de Iniciação à Docência - Pibid e dá outras providências. Disponível em: <http://www.planalto.gov.br/ccivil_03/_ato2007-2010/2010/decreto/d7219.htm>. Acesso em: 20 mar. 2017.
} 


\section{Metodologia}

Para a realização desta investigação, foi utilizada a pesquisa de caráter descritivo-qualitativa. De acordo Mattos e Neira, ${ }^{5}$ "o método descritivoqualitativo tem como características: observar, registrar, analisar, descrever e correlacionar fatos ou fenômenos sem manipulá-los, procurando descobrir com precisão a frequência em que um fenômeno ocorre e sua relação com outros fatores". Como instrumento de coleta de dados, utilizou-se um questionário com dez perguntas abertas e fechadas. Os procedimentos para a coleta de dados foram realizados em cinco momentos, descritos a seguir: 1) a triagem de docentes, bolsistas e ex-bolsistas que participam/participaram do subprojeto: "Redescobrindo a Educação Física nos Anos Iniciais do Ensino Fundamental"; 2) contato com os entrevistados, para averiguar sua aceitação em participar da pesquisa; 3) entrega e aceite do Termo de Consentimento Livre e Esclarecido; 4) entrega dos questionários a dez docentes dos Anos Iniciais do Ensino Fundamental, a cinco bolsistas que atuam no referido subprojeto e a dezoito exbolsistas que atuaram no subprojeto; e 5) recolhimento dos questionários após quinze dias, prazo dado aos participantes para a entrega da pesquisa.

\section{Análise e discussão dos resultados}

Os resultados da análise feita por este estudo foram construídos no período de março a abril de 2016, a partir da aplicação de um questionário a 23 licenciados do curso de Educação Física da UCS, que atuaram como bolsistas no Pibid/UCS, sendo que, destes, 3 não devolveram o questionário. Logo, a análise dos resultados contou com um universo de 20 participantes. O mesmo questionário foi aplicado, também, a 10 professoras dos Anos Iniciais do Ensino Fundamental da escola-parceira.

Quanto ao perfil dos bolsistas respondentes, tem-se o seguinte: 12 são do sexo feminino e 8, do sexo masculino, que atuaram como bolsistas no citado programa, em diferentes períodos: dois atuaram por três meses; um, por quatro meses; dois, por 11 meses; sete, por 1 ano; dois, por 1 ano e 3 meses; e dois deles por 2 anos. Desse grupo, quatro bolsistas ainda participam do projeto. Os

\footnotetext{
${ }^{5}$ MATTOS, M. G.; NEIRA, M. G. Educação Física na adolescência: construindo o conhecimento na escola. São Paulo: Phorte, 2000. p. 15.
} 
bolsistas, à época, cursavam entre o quarto e o sétimo semestres, quando ingressaram no Pibid.

De acordo com os resultados, constatou-se que houve uma rotatividade de bolsistas atuando no subprojeto, e os que permaneceram por menos de um ano foi em decorrência da conclusão do curso, indisponibilidade de tempo e/ou por terem ingressado no mercado de trabalho. No entanto, os bolsistas que participaram por um ano ou mais justificaram o interesse em continuar no programa, como sendo uma oportunidade de atuar no futuro campo profissional.

Em relação aos 10 docentes que participaram deste estudo, são todos do sexo feminino, sendo que: sete já atuam no Magistério de 5 a 10 anos; duas atuam por um período de 11 a 15 anos; e uma delas atua há 20 anos. As respectivas respondentes concluíram sua graduação no período de 2008 a 2015, em distintas áreas do conhecimento: seis docentes possuem graduação em Pedagogia; duas, em nível médio modalidade Magistério, concluído nos anos de 2009 e 2010; uma possui Licenciatura em Educação Física e Pedagogia; e uma é graduada em Licenciatura Plena em Educação Artística. Ao analisar as informações referentes à formação continuada das docentes, constatou-se que sete possuem especialização em diferentes áreas do conhecimento, sendo elas: Matemática, Inspeção Escolar, Supervisão Escolar e Orientação Escolar, Psicopedagogia, Gestão Escolar e Educação Infantil.

Segundo Neira, ${ }^{6}$ na sociedade atual, o professor desempenha um papel fundamental na mediação dos processos constitutivos da cidadania dos alunos. Os autores consideram que, para ocorrer uma superação do fracasso e das desigualdades escolares, é necessário, prioritariamente, repensar a formação desses profissionais.

O avanço do conhecimento, nas últimas décadas, e o seu interrelacionamento com o desempenho profissional trouxeram à tona a necessidade de atualização e aperfeiçoamento dos que atuam na educação. Nesse viés, portanto, destaca-se a formação continuada como possibilidade de alavancar o crescimento pessoal-profissional do educador, principalmente, por não se articular claramente com a tradição e a história da formação inicial do educador. Durante séculos, a formação tradicional foi considerada suficiente para preparar o indivíduo para a vida profissional.

\footnotetext{
${ }^{6}$ NEIRA, M.G. Educação Física: desenvolvendo competências. 2. ed. São Paulo: Phorte, 2006.
} 
A formação continuada, na visão de Nóvoa, ${ }^{7}$ atende ao profissional nas diferentes fases de desenvolvimento pessoal-profissional: na fase inicial, na fase da maturidade e na fase da consolidação de sua carreira. Em todas elas, o fio condutor do trabalho de formação continuada é a prática profissional em permanente processo de transformação. Dessa forma, compete-Ihes aperfeiçoar os conhecimentos que os professores já têm, visando a uma ação sobre a própria ação de educar, nos contextos onde atuam. É no confronto e na reflexão, a partir das práticas e dos saberes pedagógicos, que os professores criam novas práticas.

Os acadêmicos foram questionados sobre quais motivos os levaram a participar do Pibid. Em resposta, 19 entrevistados citaram diferentes motivos, entre eles, enfatizaram: a aproximação com o campo de atuação, o que thes possibilitou conhecer as dificuldades da prática pedagógica; a vivência no contexto social de uma escola; a descoberta de novas metodologias, colocandoas em prática e unindo a teoria estudada durante a graduação com a prática no futuro campo profissional; e a troca de experiências. Além desses, também foram destacados outros motivos como: "convite", "curiosidade" e "remuneração". Um respondente destacou que foi motivado a ser bolsista da Capes, porque essa experiência deixa o currículo profissional mais qualificado, e outro referiu que a participação no programa auxilia na quitação do Fundo de Financiamento Estudantil (Fies).

Observa-se que os motivos que levaram os licenciados a participar do Pibid relacionam-se com o objetivo de interagir no ambiente escolar, fazendo dialogar a teoria com a prática, para uma maior reflexão acerca do aprimoramento dos saberes docentes.

Os bolsistas, ao serem questionados sobre as contribuições do subprojeto para os educandos, na escola-parceira, foram unânimes em afirmar a importância da presença de um profissional de Educação Física em sala de aula. Outras contribuições constatadas foram: aprimoramento do desenvolvimento motor, cognitivo e afetivo dos alunos; melhoria na relação professor-aluno e na de aluno-aluno; vivência de diferentes manifestações da cultura corporal do movimento; novas experiências de modalidades esportivas e diversificação de brincadeiras recreativas. A partir dos depoimentos, evidenciou-se a superação do método tradicional de ensino, o que possibilitou aos bolsistas a chance de testarem metodologias e estratégias pedagógicas inovadoras.

\footnotetext{
${ }^{7}$ NÓVOA, A. Os professores e sua formação. Lisboa: Dom Quixote, 1995.
} 
Em relação à opinião das professoras participantes, as mesmas afirmaram que o subprojeto contribui positivamente no desenvolvimento integral dos alunos, pois aprimora habilidades necessárias para realizar tarefas em seu dia a dia, bem como aumenta o interesse e a participação deles na realização das atividades propostas em aulas de Educação Física. Os mesmos destacaram, também, que houve uma melhora na sua prática pedagógica, principalmente, quando da realização das atividades em conjunto com os bolsistas, o que possibilitou a troca de experiências e de conhecimento, proporcionando aulas com aprendizagens significativas, a partir de atividades criativas e inovadoras.

Os docentes salientaram que é nos anos iniciais que os educandos precisam ser estimulados a desenvolver os aspectos cognitivos, afetivos e motores. Portanto, a aula de Educação Física deve ser bem-planejada, visto que têm o objetivo de auxiliar na formação e no desenvolvimento global da criança.

Vale destacar a importância da formação continuada para o bom planejamento das aulas, por meio de novas metodologias e estratégias de ensino inovador. Aulas criativas, atividades diversificadas e significativas, que contemplem as diferentes manifestações da cultura corporal do movimento, são propostas pelos Parâmetros Curriculares Nacionais (PCNs) da Educação Física.

Nesse sentido, de acordo com os PCNs o componente curricular de Educação Física é tão importante quanto as outras disciplinas que compõem a grade curricular escolar, pois a mesma tem por finalidade "introduzir e integrar o aluno na cultura corporal de movimento, formando o cidadão que vai produzi-la, reproduzi-la e transformá-la, capacitando-o, em benefício do exercício crítico da cidadania e da melhoria da qualidade de vida". ${ }^{8}$

A participação no Pibid também contribuiu, positivamente, na formação docente dos licenciandos, principalmente dos já graduados e que já vêm atuado em sala de aula. Outro aspecto elencado pelos bolsistas é a aquisição de competências e habilidades necessárias para a atuação docente. Referiram que a experiência melhora o posicionamento do professor diante da turma, facilita o planejamento e o desenvolvimento das aulas, pois desenvolve atividades que condizem com a idade dos alunos e, ainda, auxilia na construção da identidade docente. Destacaram, também, que diminuiu a distância entre a teoria e a

\footnotetext{
${ }^{8}$ BRASIL. Secretaria de Educação Fundamental. Parâmetros Curriculares Nacionais: Educação Física. Brasília, DF: MEC/SEF, p. 28, 1996.
} 
prática, pois o bolsista é inserido no seu futuro campo de trabalho, sentindo-se mais seguro e determinado.

Ao se desenvolver um projeto, é sabido que, no decorrer do mesmo, poderão ocorrer pontos positivos e pontos negativos. Com o intuito de verificar o impacto do subprojeto no cotidiano da sala de aula, solicitou-se que as participantes elencassem as ações positivas e as negativas. Através disso, constatou-se que nove respondentes citaram ações, destas, seis mencionaram ações negativas, como, por exemplo, "falta de comprometimento dos bolsistas com a turma" e "bolsistas que chegavam atrasados para o início das atividades".

De acordo com o regulamento do Pibid, expresso no art. 43, inciso II, explicita os deveres dos bolsistas de iniciação à docência, os quais devem "dedicar-se no período de vigência da bolsa, no mínimo 8 horas semanais, às atividades do Pibid, sem prejuízo do cumprimento de seus compromissos regulares como discentes". (BRASIL, 2010). Em contrapartida, três respondentes mencionaram ações positivas, citando, por exemplo: "atividades inovadoras", "conhecimento do assunto abordado", "criatividade", "organizados", "competentes", "explicações claras" e "responsáveis."

Logo percebe-se que os objetivos do Pibid foram alcançados, visto que os licenciados articularam a teoria com a prática. Também desenvolveram ações pedagógicas interdisciplinares, durante o processo de ensino e aprendizagem; estimularam a inovação, a ética profissional, a criatividade e habilidades docentes para uma práxis transformadora.

Embora tenham sido constatadas algumas fragilidades no desenvolvimento do subprojeto, as docentes apresentaram sugestões para sanar as lacunas, tais como: "dar continuidade ao Pibid na escola-parceira", "trazer atividades diversificadas", "estar comprometidos com a turma", "ensinar os educandos a serem competitivos". Nesse contexto, considera-se importante a sugestão dada pelas educadoras, para que os bolsistas realizem, constantemente, a autoavaliação de suas práticas, o que lhes permite reelaborar as ações e, com isso, qualificar o subprojeto.

\section{Considerações finais}

Em virtude das indagações levantadas por este estudo, pode-se destacar que o Pibid é um programa relevante para a articulação entre teoria e prática, necessária na formação inicial de docentes, contribuindo, desse modo, para que 
os bolsistas se insiram na cultura escolar, por meio da apropriação dos e da reflexão sobre instrumentos e saberes relativos ao trabalho docente. A participação no Pibid eleva a qualidade das ações acadêmicas, traz mais segurança na prática dos estágios curriculares e na atuação no campo profissional.

Diante dos argumentos apresentados pelos respondentes, salienta-se que o subprojeto apresentou pontos negativos, porém os aspectos positivos predominaram. Destaca-se que o Pibid é um programa qualificado, que visa a aperfeiçoar a educação pública brasileira e, também, proporcionar ao licenciando a experiência de se inserir no seu futuro campo de trabalho.

O Pibid-UCS, por meio do subprojeto citado, aproximou a UCS - Campus Universitário de Vacaria, da escola pública. Essa inserção propiciou melhorias na qualidade do ensino da Educação Física nos Anos Iniciais do Ensino Fundamental da escola-parceira.

Nesse sentido, ressalta-se que o papel do componente curricular de Educação Física tem suma importância; porém, as aulas precisam ser planejadas com objetivos, procedimentos e estratégias metodológicas diversificadas, no sentido de auxiliar na formação e no desenvolvimento global dos educandos.

Ressalta-se que as sugestões elencadas pelos docentes da escola-parceira contribuem para que o grupo de bolsistas reflita e ressignifique suas ações, quanto à responsabilidade e assiduidade, que devem marcar as atividades que são realizadas na escola.

Assim, com base nos resultados obtidos neste estudo, conclui-se que o professor de Educação Física desempenha um papel de extrema importância na sala de aula. O relatório da Delores, ${ }^{9}$ lembra que o educador prepara seu educando para desenvolver as habilidades de aprender a ser, aprender a conviver, aprender a conhecer e aprender a fazer, sendo esses os quatro pilares da educação. Com base nesses princípios, percebe-se que é possível garantir melhor desenvolvimento global dos estudantes ao longo da vida.

As pesquisadoras concluem que o presente estudo não está, aqui, encerrado, pois poderão surgir, futuramente, outras pesquisas referentes à temática investigada, trazendo outras informações relevantes.

\footnotetext{
${ }^{9}$ DELORS, J. (Coord.). Educação: um tesouro a descobrir. São Paulo: Cortez, 1998.
} 


\section{Referências}

BRASIL. Lei 9.394/1996a. Lei de Diretrizes e Bases da Educação Nacional. Disponível em: <http://www.planalto.gov.br/>. Acesso em: 7 maio 2017.

BRASIL. Secretaria de Educação Fundamental. Parâmetros Curriculares Nacionais: Educação Física. Brasília, DF: MEC/SEF, p. 28, 1996.

BRASIL. Decreto 7.219/2010. Dispõe sobre o Programa Institucional de Bolsa de Iniciação à Docência - Pibid e dá outras providências. Disponível em: <http://www.planalto.gov.br/ccivil_03/_ato2007-2010/2010/decreto/d7219.htm>. Acesso em: 20 mar. 2017.

BRASIL. Portaria 096/2013. Regulamenta o Programa Institucional de Bolsa de Iniciação à Docência (Capes, 2013). Disponível em: <https://www.capes.gov.br/images/stories/download/legislacao/Portaria_096_18jul13> . Acesso em: 7 mar. 2017.

BRASIL. Lei 12.796/2013. Altera a Lei 9.394, de 20 de dezembro de 1996, que estabelece as diretrizes e bases da educação nacional, para dispor sobre a formação dos profissionais da educação e dar outras providências. Disponível em: <http://www.planalto.gov.br/ccivil_03/Ato2011-2014/2013/Lei/L12796.htm>. Acesso em: 7 maio 2017.

DELORS, J. (Coord.). Educação: um tesouro a descobrir. São Paulo: Cortez, 1998.

MATTOS, M.G.; NEIRA, M.G. Educação Física na adolescência: construindo o conhecimento na escola. São Paulo: Phorte, 2000. p. 15.

NEIRA, M.G. Educação Física: desenvolvendo competências. 2. ed. São Paulo: Phorte, 2006.

NÓVOA, A. Os professores e sua formação. Lisboa: Dom Quixote, 1995. 


\title{
5 \\ TEMAS DO UNIVERSO CULTURAL DOS ESTUDANTES COMO CONTEÚDO DE ARTE
}

\author{
Alex Joacir Pessôa de Oliveira Júnior \\ ajpojunior@gmail.com \\ Subprojeto Artes Plásticas e Visuais* \\ Escola Municipal de Ensino Fundamental Caldas Júnior
}

\begin{abstract}
Resumo: Este artigo aborda a experiência em torno de um projeto pedagógico realizado no âmbito do PIBID/Artes Visuais. Ele comenta as origens e o desenvolvimento da educação em artes no Brasil e sua histórica desvalorização por parte do Estado e da sociedade. Discute sobre possíveis conteúdos a serem trabalhados na escola, a partir de temas geradores. Relata uma experiência realizada com o 70 ano da EMEF Caldas Júnior em Caxias do Sul (RS), em torno do tema "animação".

Palavras-chave: Ensino de artes visuais. Temas geradores. Animação.
\end{abstract}

\section{Introdução}

Este artigo foi produzido a partir de um projeto pedagógico desenvolvido no Programa Institucional de Bolsas de Iniciação à Docência - Subprojeto Artes Plásticas e Visuais, com uma turma de 70 ano da EMEF Caldas Júnior, em Caxias do Sul, RS. O tema escolhido para trabalhar no projeto foi a "animação", pois trata-se de um assunto presente na cultura dos estudantes. Durante a execução do projeto, os estudantes estudaram a história da animação, seus diferentes tipos e suas formas de produção. Além disso, também produziram sua própria animação.

A seleção desse tema buscou tornar as aulas de $\operatorname{Arte}^{1}$ mais atrativas para os alunos, pois observamos certa desvalorização desse componente curricular por parte deles em geral. Assim, um tema relacionado ao cotidiano dos estudantes foi levado à sala de aula. A ideia de unir o universo cultural dos alunos com um conteúdo escolar partiu do conceito de temas geradores desenvolvidos por Paulo Freire. (CorAzZA, 2003).

A concepção de que os conteúdos de Arte se resumem ao desenho prejudica a aceitação e a construção de novos conhecimentos. Isso é perceptível

\footnotetext{
* Coordenadora do subprojeto: Profa. Dra. Maria Helena Wagner Rossi. Supervisora: Profa. Rosebel Rech.

${ }^{1}$ A palavra Arte, com a inicial maiúscula, designa o componente curricular na Educação Básica.
} 
na sala de aula, na forma do desinteresse dos estudantes pelo componente curricular Arte. A desvalorização relacionada ao ensino de artes no Brasil existe desde os tempos imperiais, conforme será abordado a seguir, para contextualizar o projeto desenvolvido na escola.

\section{A presença da arte na educação formal brasileira}

Conforme Barbosa (2002), o ensino de artes visuais foi trazido ao Brasil no século XVIII por meio das Missões Jesuíticas. Porém, não o foi como um ensino formal com ênfase no aguçamento intelectual dos aprendizes, mas uma instrução de procedimentos artesanais baseados no estilo Barroco-Rococó, presente na Europa à época.

A chegada da família imperial portuguesa no Brasil, em 1808, resultou em algumas modificações na estrutura governamental na então Colônia, como a criação da Escola Médico-Cirúrgica, a Academia Militar e a Academia Real de Ciências, Artes e Ofícios. (PRIORE; VenÂNCIO, 2001).

Joachim Lebreton, diretor da Seção de Belas-Artes da França, foi encarregado de unir e liderar um grupo de artistas e artífices para organizar o ensino das Belas-Artes no Brasil. Em 1816 esse grupo, conhecido como Missão Artística Francesa, trouxe o estilo Neoclássico para um país em que o estilo Barroco-Rococó predominava. Assim, de acordo com Barbosa (2002), houve um conflito estético: os artistas brasileiros com suas ingênuas produções foram inferiorizados devido à chegada dos europeus, que passaram a organizar as decorações públicas para as festas oficiais. Isso gerou um preconceito em relação às artes visuais de ordem estética, pois o povo que produzia arte no estilo Barroco rejeitou a arte neoclássica.

Barbosa ainda explica que a questão política também é responsável pelo surgimento da desvalorização relacionada à arte. Os artistas franceses que vieram para o Brasil eram, no geral, bonapartistas. Em contrapartida, o Brasil mantinha uma rejeição a Napoleão, devido à invasão à Portugal. Sendo assim, a população mostrou-se contra os artistas franceses e contra a arte que eles produziam.

Houve também um preconceito oriundo dos nobres com a arte da população, porém no contexto da arte industrial. Segundo Ferreira (1876, apud 
BARBOSA, 2002), a arte industrial no Brasil era produzida pelos escravos. Como os homens livres consideravam-se superiores, não ousavam produzir esse tipo de arte, temendo nivelarem-se aos africanos.

Os ideais que geraram a abolição da escravatura, em 1888, e a proclamação da República, em 1889, também influenciaram a educação. Baseando-se no projeto de reforma de ensino de Rui Barbosa, a arte foi integrada à educação. (BARBOSA, 2002). Contudo, esse ensino foi limitado ao desenho industrial e geométrico. Essa medida foi tomada no início do século $X X$, mas pode-se dizer que a ideia de que a Arte se limita ao desenho ainda existe. Essa reflexão surgiu quando os alunos do 70 ano foram indagados sobre quais conteúdos gostariam de abordar nas aulas de Arte. Suas respostas limitaram-se a mencionar o desenho. Isso gerou certo estranhamento, tendo em vista que os estudantes estavam livres para escolher qualquer conteúdo. Portanto, é importante pensar em novas abordagens para o ensino de Arte, incorporando as contribuições dos teóricos contemporâneos, que propõem a ampliação de abordagens, tais como Ana Mae Barbosa (1998), com a abordagem triangular e Fernando Hernández e Montserrat Ventura (1998) com a organização do currículo por projetos.

Ao longo do século $\mathrm{XX}$, o ensino de arte passou por algumas mudanças, mas somente nos anos 1970, devido à Lei 5.692/71, o ensino de Arte foi introduzido como obrigatório no currículo escolar, com a nomenclatura de Educação Artística. Contudo, de acordo com Ferraz e Fusari (2010), a Educação Artística foi influenciada pela pedagogia tecnicista e tratada de modo indefinido, pois referia-se a uma área bastante ampla. Além disso, a Lei agregava o ensino de música e de artes cênicas, além das artes visuais, gerando polivalência, postura duramente criticada pelos teóricos da arte-educação.

Em 1986, às vésperas da implantação de uma nova Constituição, o ensino de arte correu o risco de ser retirado da educação. Segundo Barbosa (1991, p. 1), durante uma reunião de secretários da Educação, a maioria concordou com a eliminação da Arte nas escolas. Diante desse acontecido, a autora ponderou:

A roupa que vestem (os secretários) é produto de desenho, o tecido de suas roupas é produto das artes na indústria têxtil, a cadeira em que sentam alguém desenhou, em geral algum estrangeiro, mesmo que ela tenha sido produzida no Brasil, porque temos pouca gente que foi educada para ser 
competente em desenho. E a culpa é dos fazedores de currículo. (BARBOsA, 1991, p. 2).

Contudo, essa exclusão não ocorreu devido à luta dos arte-educadores brasileiros apoiados pela Federação de Arte-Educadores do Brasil (Faeb), mantendo a Educação Artística nos currículos.

No início do século XXI, houve a inclusão do ensino de dança, música e teatro ao componente curricular Arte. Em 2017, com o propósito explícito de diminuir a desigualdade educacional em âmbito nacional, foi lançada a Base Nacional Comum Curricular (BNCC). Esse documento, supostamente organizado com o auxílio de educadores e da sociedade, define "os direitos de aprendizagens essenciais para os estudantes do Brasil". (BRASIL, 2017). No âmbito da Arte, a BNCC define o conjunto de aprendizagens essenciais a que todos os alunos têm direito para as quatro linguagens, estabelecendo objetivos para o ensino do componente curricular.

No entanto, a reforma do Ensino Médio, cuja lei foi promulgada no início de 2017, novamente desvaloriza a Arte, bem como outros componentes curriculares, que tiveram sua obrigatoriedade revogada. À vista disso, educadores de todo o País discutiram e formularam cartas de repúdio.

Após analisar o ensino das Artes Visuais na educação formal brasileira, é possível notar que ele foi desvalorizado em alguns períodos. Ao longo da sua história, esse componente passou por algumas ameaças de exclusão nas escolas e, frequentemente, sua carga horária é reduzida, variando de um a dois períodos semanais. Além disso, as quatro linguagens devem ser oferecidas nesse componente curricular, o que reduz drasticamente a carga horária das Artes Visuais.

Essa desvalorização parte tanto do Estado como da sociedade, e a Arte é vista como supérflua pelos alunos. Assim, o projeto desenvolvido no âmbito do Pibid/Artes Visuais buscou contribuir para a valorização desse componente curricular, na medida em que objetivou despertar o interesse dos alunos pela arte. Para alcançar esse objetivo, desenvolveu-se um trabalho em torno de novos conteúdos, visando à aproximação entre a cultura dos alunos e a educação formal. 


\section{O método Freire e os temas presentes no cotidiano dos estudantes}

Objetivando despertar o interesse dos estudantes em relação à Arte, surgiu a seguinte questão: Qual tema deveria ser trabalhado, para que esse objetivo fosse alcançado? Para responder a essa interrogação, a estratégia de ensino baseou-se nas ideias de Paulo Freire, adaptando sua abordagem ao campo das artes e ao contexto do projeto. (CORAZZA, 2003).

O método de Paulo Freire, abordado no livro de Sandra Corazza "Tema Gerador", tem como característica a aproximação entre os conteúdos escolares e o universo dos educandos. Assim, os estudantes são alfabetizados com palavras que designam elementos presentes no seu cotidiano, como, por exemplo, as palavras tijolo e fábrica, para instruir operários. Com esse método, Paulo Freire alfabetizou 300 adultos em 40 horas-aula, mostrando que aproximar a educação do universo dos alunos facilita a construção do conhecimento. (CORAZZA, 2003).

A aplicação do método é dividida em algumas etapas. Contudo, neste projeto o número de etapas foi reduzido. Segundo Corazza (2003), a primeira fase é a investigação do universo vocabular dos estudantes, que são as palavras que caracterizam sua cultura. Nas pesquisas posteriores de Freire, a investigação foi modificada, buscando compreender os temas presentes no universo dos estudantes.

Da pesquisa temática é possível descobrir assuntos que permeiam a mente dos estudantes e, assim, auxiliá-los a refletirem sobre eles. De acordo com Kramer et al. (1989, apud CORAZZA, 2003), os temas descobertos na pesquisa são responsáveis por proporcionar a articulação de um trabalho pedagógico, visto que, ao utilizar assuntos retirados do universo dos estudantes, o docente respeitará os interesses que são manifestados por eles. Por possuírem essa capacidade de gerar uma atividade pedagógica, esses temas são chamados de "temas geradores". A vantagem de utilizar esse método está em estabelecer um ambiente de trabalho conjunto e de cooperação, pois as vontades dos alunos são atendidas.

Além de Paulo Freire, outros teóricos ressaltam a importância de unir a cultura dos alunos com os conteúdos escolares, tal como Rosa lavelberg (2003, p. 62), quando afirma que o professor "poderá trazer, para a sala de aula, tanto o contexto da cultura dos jovens estudantes como os conteúdos universais. Não se 
trata de caminhar do mais simples para o mais complexo, e sim de relacionar o contexto de vida e a experiência dos alunos com os conteúdos escolares".

Visando à construção de um projeto pedagógico em conjunto com os alunos, a pesquisa temática foi realizada em sala de aula. Em seguida foi decidido qual seria o tema do projeto, que deveria estar relacionado com o contexto dos estudantes e com as respostas da pesquisa temática. Dessa forma o tema deste projeto foi a animação. Trata-se de assunto presente na vida dos jovens, seja por meio de desenhos animados, filmes e até mesmo jogos. Sendo assim, as aulas foram planejadas, para que o ensino do desenho fosse agregado à animação. Dessa forma, o projeto Pibid/Artes Visuais possibilitou o estudo de um conteúdo inusitado às aulas da turma e, assim, possibilitando novos conhecimentos.

\section{Animação no ensino de artes visuais}

A animação é um assunto rico e importante no cenário mundial. Possui duas categorias no Oscar: Melhor Curta-Metragem Animado e Melhor Animação. Também é foco de diversos festivais e premiações restritas à sua categoria no mundo. Mesmo assim, é pouco trabalhada na educação.

Os princípios da animação já podiam ser encontrados na pré-história com as pinturas rupestres, como, por exemplo, na representação de um javali com oito patas feita há 30 mil anos nas cavernas de Altamira, na Espanha. Tendo em vista a repetição dos membros do animal, essa pintura é considerada como uma animação. (LUCENA JúNIOR, 2002).

A animação no sentido contemporâneo teve origem ao longo do século XIX. Segundo Lucena Júnior (2002, p. 33-35), as pessoas "questionavam a respeito do fenômeno de perceber os raios das rodas das carruagens girando ao contrário, ou mesmo ficando parados, quando o veículo se movia rapidamente". Estudando o assunto, Peter Mark Roget publicou o artigo "The persistence of vision with regard to moving objects", em 1824, no qual explica que o olho humano retém uma imagem por uma fração de segundo, enquanto percebe outra. Sendo assim, as imagens se sobrepõem, o que gera o efeito de movimento. A partir deste estudo, surgiram diversos aparatos óptico-mecânicos, que exploravam as possibilidades de gerar a ilusão de movimento. Dentre eles o Taumatroscópio e o Zootroscópio. 
Em 1878, Eadweard Muybridge criou um método capaz de fotografar o movimento de uma cavalgada em sequência. Os resultados obtidos com esse estudo permitiram o advento do cinematógrafo, que foi criado pelos irmãos Lumière em 1895, a partir do aperfeiçoamento de uma invenção de Thomas Edison. Esse aparelho, utilizado para produzir os primeiros filmes, servia tanto para filmar quanto para projetar. (LUCENA JÚNIOR, 2002).

A partir dessas invenções, o uso da fotografia e da filmagem foi incorporado à produção da animação, como, por exemplo, em "Humorous Phases of Funny Faces", de 1906, criada por James Blackton - uma animação produzida por desenhos fotografados em um quadro negro. Outras inovações no início do século XX serviram para desenvolver a produção da animação, o que culminou com o primeiro longa-metragem da categoria, o filme "A Branca de Neve e os sete anões", de 1937, lançado pelos Estúdios Disney. (LUCENA JúNIOR, 2002).

Apesar das dificuldades enfrentadas pela indústria da animação brasileira, ela vem crescendo e recebendo algumas premiações. É o caso de "Uma história de amor e fúria", de Luiz Bolognesi, que venceu o prêmio Cristal em 2013 e "O menino e o mundo", de Alê Abreu, que recebeu o prêmio Cristal de Melhor Filme do Júri, o Prêmio do Público em 2014 e foi indicado à melhor animação do Oscar de 2016. Contudo, o que mais cresce são as animações produzidas para a televisão, feitas em conjunto com canais como Cartoon Network e Discovery Kids. (Sebrae, 2014).

Mesmo com diversas possibilidades de aplicação na educação, a animação é pouco trabalhada na escola. Isso dificulta a formação de possíveis profissionais da área e resulta na existência de poucos estúdios e animações nacionais. 0 objetivo de levar a animação à escola era atrair o interesse dos estudantes em relação à arte e também oferecer a possibilidade de conhecer um novo tema.

\section{Relato de experiência}

O projeto foi realizado ao longo de 33 encontros de dois períodos escolares com a turma 72 do sétimo ano do Ensino Fundamental. Como esperado, os alunos ficaram empolgados com a chegada de um novo educador, que atuaria em conjunto com a professora titular. 
A primeira aula foi destinada à pesquisa temática, a partir de perguntas como: O que vocês desejam aprender? Quais assuntos vocês gostariam que fossem trabalhados em aula? Os estudantes mostraram interesse pelo "desenho da figura humana, desenho de objetos e luz e sombra". Entretanto, a Arte abrange muito mais assuntos do que o desenho, pois no seu ensino é possível trabalhar com diversos materiais e linguagens.

Posteriormente à pesquisa temática, chega-se à seguinte questão: Como os alunos poderiam entender que a arte engloba outros assuntos além do desenho? Desse modo, decidiu-se desenvolver um projeto pedagógico sobre um tema não comentado pelos estudantes, mas que faz parte de seu universo cultural. Assim, foi sugerida a animação, pois trata-se de um assunto presente na cultura dos estudantes e pouco trabalhado nas escolas.

No livro Arte da animação, de Alberto Lucena Júnior, encontra-se a história da animação, seus principais contribuidores e seus diferentes tipos. Enquanto dedicava-me à leitura da obra, conduzi as aulas acerca dos fundamentos do desenho, com o desenho de esboço e perspectiva - elementos importantes como meio de expressão dos alunos.

A parcela do projeto destinada à animação iniciou com a contextualização do tema. Em aula expositiva dialogada, a história da animação e seus estilos foram trabalhados. Para isso foram utilizados eslaides mostrando pinturas rupestres em cavernas na Espanha, o movimento artístico-futurista e alguns aparatos que auxiliaram o desenvolvimento histórico da animação.

Na primeira atividade, os alunos analisaram o movimento de um objeto e depois o representaram por meio do desenho, utilizando os princípios do Futurismo. Essa atividade foi bem-recebida, porém os alunos não se mostraram muito motivados, pois a sensação de movimento foi trabalhada de forma primitiva.

A atividade seguinte consistiu na produção de um folioscópio. Esse aparato é caracterizado por uma folha dobrada ao meio, como um livro. Dois desenhos são feitos nesse papel, de forma que um fique sobre o outro. Ao enrolar e desenrolar na folha superior, é possível perceber a ilusão de movimento. Com a possibilidade de perceber movimento em seus desenhos, os alunos ficaram fascinados. Muitas ideias criativas surgiram ao longo da atividade, e alguns produziram mais folioscópios do que fora solicitado. Esse fato demonstrou que a 
atividade foi bem-aceita pelos estudantes, o que tornou possível ampliar as propostas.

A construção de um taumatroscópio foi a atividade posterior - objeto caracterizado por um pequeno disco sustentado por uma haste. Em cada uma das faces do disco foi feita uma ilustração. Quando o disco foi girado pelos alunos, as duas imagens se fundiram em uma única. Esse aparato não gera a sensação de movimento, mas os alunos puderam perceber os desenhos - criados separadamente - se completando. Mais uma vez as ideias foram inusitadas, abrangendo desde alimentos até rostos. Alguns alunos mostraram-se tão interessados no assunto, que produziram mais taumatroscópios do que o solicitado.

A elaboração de um flipbook foi a próxima atividade. Para tal foi solicitada a produção de dez desenhos. Assim, a partir de repetição e velocidade, a animação aconteceria. Devido ao grande número de desenhos que deveria ser realizado, essa atividade não atraiu muito os alunos; entretanto, houve bons resultados.

O movimento de aproximação e distanciamento também foi atentado neste projeto. Para isso, o livro Zoom, de Istvan Banya, foi apresentado aos alunos. Posteriormente, eles desenharam quatro quadros em uma folha $A 3$, de forma que, vistos em sequência, o efeito de zoom fosse percebido. Essa atividade atraiu mais o interesse dos alunos e muitas ideias criativas surgiram ao longo do trabalho.

A produção de um zootroscópio foi a tarefa seguinte - um aparato semelhante a um cilindro com desenhos no interior, que, quando girado, permite observar a animação pelas pequenas fissuras. Como tratava-se de um objeto tridimensional, os alunos ficaram curiosos diante de sua produção. Os resultados da atividade foram muito satisfatórios, e o movimento foi bem perceptível.

O encerramento do projeto teve como atividade a confecção de uma animação pelos alunos. Essa animação foi realizada na forma de paper motion um stop motion feito com desenhos. Os estudantes desenharam em folhas A3 cenários e personagens separadamente. Além do desenho, uma narrativa foi criada, complementando o trabalho de animação.

Para que a animação pudesse ser realizada, os desenhos foram fotografados e as fotos foram reunidas em um vídeo que pode ser visualizado no 
YouTube. ${ }^{2}$ Os trabalhos foram apresentados para a turma. Os alunos ficaram muito felizes em assistirem suas próprias produções, de forma que alguns produziram outras animações fora do projeto.

\section{Considerações finais}

O projeto pedagógico discutido neste artigo objetivou tornar a Arte atrativa aos estudantes. Para que esse objetivo fosse atingido, temas relacionados à cultura dos alunos foram levados à sala de aula. Neste caso, o tema escolhido foi a animação, por estar presente no cotidiano dos adolescentes.

Apesar de ser um tema com grande importância atualmente, a produção da animação ainda não era conhecida pelos alunos, que mostravam-se fascinados a cada descoberta. Levar um assunto como animação à sala de aula despertou o interesse dos estudantes para com esse tema. A formação de novos animadores, que poderão exercer essa atividade profissionalmente, passa por esse processo de familiarização na escola. Entretanto, é importante reconhecer que a educação não deve ser direcionada para o mercado de trabalho, mas para a construção do conhecimento dos estudantes. Dessa maneira, o Pibid/Artes Visuais proporcionou uma nova experiência na vida escolar dos alunos e o conhecimento de novos temas.

\section{Referências}

BARBOSA, Ana Mae Tavares Bastos. A imagem no ensino da arte. São Paulo: Perspectiva, 1991.

BARBOSA, Ana Mae Tavares Bastos. Arte-educação no Brasil. 5. ed. São Paulo: Perspectiva, 2002.

BARBOSA, Ana Mae Tavares Bastos. Tópicos utópicos. Belo Horizonte: C/ Arte, 1998.

BRASIL, Ministério da Educação. Base Nacional Comum Curricular. Disponível em: <https://www.youtube.com/watch?v=g2_9XIE18NA>. Acesso em: 21 set. 2017.

\footnotetext{
${ }^{2}$ Disponível em: <https://youtu.be/vpFcMSntf5k>.
} 
CORAZZA, Sandra Mara. Tema gerador: concepção e práticas. 3. ed. ljuí, RS: Ed. da Unijuí, 2003.

FERRAZ, Maria Heloísa C. de T.; FUSARI, Maria F. de Rezende e. Arte na educação escolar. 4. ed. São Paulo: Cortez, 2010.

FREIRE, Paulo. Educação e mudança. 19. ed. São Paulo: Paz e Terra, 1993.

HERNÁNDEZ, Fernando; VENTURA, Montserrat. A organização do currículo por projetos de trabalho: o conhecimento é um caleidoscópio. 5. ed. Porto Alegre: Artmed, 1998.

IAVELBERG, Rosa. Para gostar de aprender arte: sala de aula e formação de professores. Porto Alegre: Artmed, 2003.

LUCENA JÚNIOR, Alberto. Arte da animação: técnica e estética através da história. 3. ed. São Paulo: Senac, 2011.

PRIORE, Mary del; VENÂNCIO, Renato Pinto. O livro de ouro da história do Brasil. Rio de Janeiro: Ediouro, 2001.

SEBRAE. O crescente mercado da animação no Brasil. 2014. Disponível em: <http://www.sebraemercados.com.br/wpcontent/uploads/2015/10/2014_08_14_BO_Julho_EC_Animacao_pdf.pdf $>$. Acesso em: 24 out. 2017. 


\title{
Ciências Biológicas
}

\section{6}

\section{A INICIAÇÃO À DOCÊNCIA COM PROJETOS DE HORTA ESCOLAR PARA O ENSINO DE CIÊNCIAS}

\author{
Tatiane Eitelven ${ }^{*}$ \\ tatiane.eitelven@hotmail.com \\ Luana Boeira* \\ Iboeira29@gmail.com \\ Lisiane de Souza $^{* *}$ \\ desouza.lisiane@gmail.com \\ Dra. Gladis Frank da Cunha** \\ gfcunha2@ucs.br \\ Subprojeto Pibid Biologia-Carvi \\ Escola Municipal de Turno Integral São Roque
}

\begin{abstract}
Resumo: Desde os anos iniciais, os estudantes podem ser motivados à pesquisa e a se encantarem com a descoberta. Este encanto inicial torna-se determinante para um ensino consistente e mais próximo da realidade dos estudantes. A construção do conhecimento em Ciências acontece de modo gradual introduzindo os estudantes ao universo da descoberta, da observação, das relações e do aprendizado. Percebe-se que eles, "encantados" pelos fenômenos naturais, são curiosos e interessados; permanecem atentos e concentrados nas atividades propostas pelo professor. Nesse campo da descoberta, a "horta escolar" desponta como uma grande ferramenta de trabalho. O projeto "Construindo Conhecimentos em Ciências com a Horta Escolar" foi realizado na Escola Municipal de Turno Integral São Roque Professora Nilza Côvolo Kratz, com alunos do primeiro ao sétimo ano do ensino fundamental no turno da tarde. 0 desenvolvimento do projeto foi possível devido à parceria da escola com o Programa Institucional de Iniciação a Docência, Pibid/Biologia/Carvi-UCS. Esse projeto teve como objetivos desenvolver habilidades e competências a partir das diversas atividades relacionadas à horta escolar; promover relações entre os conteúdos teóricos de diversas disciplinas com o meio natural; incentivar a alimentação saudável com o cultivo de hortaliças. Diante dessa proposta estruturaram-se três subprojetos: a reconstrução da horta escolar, o terrário e o mundo na nossa horta. O projeto foi desenvolvido de forma significativa, perdurando todo o ano letivo de 2016, sempre com novas atividades sendo incluídas, uma vez que um dos pontos relevantes da proposta era sua continuidade. E o mais importante é que as aprendizagens não eram isoladas, observou-se um aumento no interesse dos alunos pelo tema, além de conhecimentos em educação ambiental, alimentação saudável, alfabetização científica e resgate da história através do herbário. A horta escolar representou um complemento teórico essencial não somente para a área das ciências como também para outras, tornando-se uma possibilidade de colocar em prática a interdisciplinaridade.
\end{abstract}

\footnotetext{
* Bolsistas do PIBID/BIOLOGIA/CARVI - UCS e Graduandas de Licenciatura em Ciências Biológicas. ${ }^{* *}$ Supervisora PIBID/EMTI São Roque.

*** Docente do Mestrado Profissional em Ensino de Ciências e Matemática e do Curso de Ciências Biológicas - CARVI. Coordenadora do Subprojeto Biologia.
} 
Palavras-chave: Horta escolar. Ensino de ciências. Pibid.

\section{Introdução}

Ao pensarmos a formação de professores, é relevante questionarmos: Para que serve ensinar ciências? Em resposta a esta questão, um dos objetivos traçados em projetos de iniciação à docência em Ciências Biológicas, foi a alfabetização científica, ou seja, buscou-se levar os estudantes a realizarem as próprias descobertas sobre o mundo natural, partindo da premissa de que, no ensino de Ciências, os professores precisam criar situações pedagógicas que viabilizem vivências construtivas e o envolvimento pessoal de cada educando, na descoberta dos conceitos científicos. ${ }^{1}$

Desde os anos iniciais, os estudantes podem ser motivados à pesquisa e a se encantarem com a descoberta. Este encanto inicial torna-se determinante para um ensino consistente e mais próximo da realidade dos estudantes. A construção do conhecimento em Ciências acontece de modo gradual, introduzindo os estudantes ao universo da descoberta, da observação, das relações e do aprendizado. Percebe-se que eles "encantados" pelos fenômenos naturais, são curiosos e interessados, e permanecem atentos e concentrados nas atividades propostas pelo professor.

Nesse campo da descoberta, a Horta Escolar desponta como uma grande ferramenta de trabalho, pois quando inserida no ambiente escolar, ela pode ser um laboratório vivo, que possibilita o incremento de diversas atividades pedagógicas, unindo teoria e prática de forma contextualizada; ${ }^{2}$ que possibilita muitos experimentos e práticas em ciências, assim como em outros componentes curriculares, fomentando a interdisciplinaridade. Assim, na Matemática pode-se utilizar as atividades da horta para calcular as medidas e formas geométricas dos canteiros, a geografia pode explorar os locais de origem das plantas e as melhores localizações para plantio, as artes podem estimular a criatividade na construção de uma horta diferenciada. Outras sugestões poderiam indicar que todas as disciplinas cabem no amplo contexto da "horta", pois com ela é possível pesquisar, observar o desenvolvimento de mudas e

\footnotetext{
${ }^{1}$ DORNELES, L. T.; CUNHA, G. F. Biologia vegetal: manual de práticas escolares. Caxias do Sul: Educs, 2005.

${ }^{2}$ CYPRIANO, R. J. et al. Horta escolar: um laboratório vivo. Educação Ambiental em Ação (Artigos), n. 42, 2013.
} 
sementes, o tempo para amadurecer frutos, as mudanças fisiológicas nas hortaliças que desenvolvem suas sementes; investigar os fatores ambientais necessários ao desenvolvimento de cada espécie de hortaliça, tempero, chá e leguminosa; realizar pequenos experimentos com adubação e tratamentos naturais de combate às pragas e observar os seres vivos, suas cadeias alimentares e suas relações com o meio neste pequeno ecossistema. Em síntese, a horta escolar é uma estratégia capaz de promover estudos, pesquisas, debates e atividades sobre as questões ambiental, alimentar e nutricional. Além de estimular o trabalho pedagógico participativo e prazeroso, gerando aprendizagens múltiplas. $^{3}$

Com esse intuito, elaborou-se o projeto "Construindo Conhecimentos em Ciências com a Horta Escolar", que foi realizado na Escola Municipal de Turno Integral São Roque Professora Nilza Côvolo Kratz, com alunos do 1으 ao 7o ano do Ensino Fundamental, no turno da tarde. O desenvolvimento do projeto foi possível devido à parceria da escola com o Programa Institucional de Iniciação à Docência, Pibid/Biologia/Carvi-UCS. A escolha desse tema justificou-se a partir da necessidade de a escola parceira oferecer mais ênfase à Horta Escolar, uma vez que essa era uma das suas disciplinas obrigatórias para os anos iniciais e buscava atingir dois objetivos: a aprendizagem e a alimentação escolar. Por meio das ações dos pibidianos, buscou-se desenvolver habilidades e competências; estabelecer relações entre os conteúdos teóricos de diversas disciplinas com o meio natural e incentivar a alimentação saudável. Diante desses objetivos, estruturaram-se três subprojetos: 1) reconstrução da horta escolar; 2) terrário; 3) o mundo na nossa horta.

\section{Procedimentos metodológicos}

\subsection{Subprojeto 1: Reconstrução da Horta Escolar}

Ao iniciar este subprojeto, a escola já contava com um espaço composto por três canteiros para o plantio, porém esses não estavam bem-organizados, dificultando o trabalho com as crianças menores, bem como não aproveitavam a totalidade do espaço disponível. De acordo com essa realidade, projetou-se a

\footnotetext{
${ }^{3}$ BARBOSA, N. V. S. A horta escolar dinamizando o currículo da escola. 3. ed. Ministério da Educação, Brasília: Cristal, 2009. Caderno 1.
} 
reconstrução da horta, como uma atividade prática, que possibilitasse a participação de todos os alunos e utilizassem técnicas de produção de alimentos ecológicos.

Inicialmente, buscou-se identificar os locais que viabilizassem a construção de canteiros e, após, verificou-se o melhor design para a elaboração dos mesmos, a fim de possibilitar atividades com todas as turmas.

As turmas eram escolhidas para desenvolver as atividades conforme o grau de dificuldade do trabalho. Assim, as tarefas de preparação da terra e de canteiros foram realizadas por alunos do 6으 e 70 anos, enquanto o plantio e a semeadura destinaram-se aos alunos dos anos iniciais. Já a colheita e manutenção abrangeram todas as turmas.

A partir da determinação do espaço a ser utilizado foram realizadas com os alunos a medição e demarcação dos novos canteiros a serem construídos. Através da medição calculou-se a quantidade necessária de blocos de concreto, que seriam doados, para sua demarcação. Em seguida, iniciou-se a limpeza do local. Após a chegada dos blocos, delimitaram-se canteiros de forma retangular, com corredores largos entre eles, para facilitar o trabalho e a movimentação das crianças. Os canteiros tiveram que ser estruturados mais estreitos, para que os alunos menores pudessem alcançar o seu centro, bem como os corredores precisaram ser mais largos, para facilitar o trabalho em dois canteiros, concomitantemente. Utilizou-se a medida de $60 \mathrm{~cm}$ de espaço entre os canteiros seguindo a orientação para facilitar as atividades com os alunos e os trabalhos de manutenção da horta. ${ }^{4}$ Assim que ficaram prontos (Figura 1), as primeiras sementes semeadas foram de rabanetes e ervilhas. Em seguida, plantaram-se mudas de alface e repolho, disponíveis no mercado.

\footnotetext{
${ }^{4}$ FERNANDES, M. C. A. Orientações para implantação e implementação da horta escolar. 3. ed. Ministério da Educação, Brasília: Cristal, 2009. Caderno 2.
} 
Figura 1 - Horta, após processo de reconstrução e já com o plantio de mudas e semeaduras

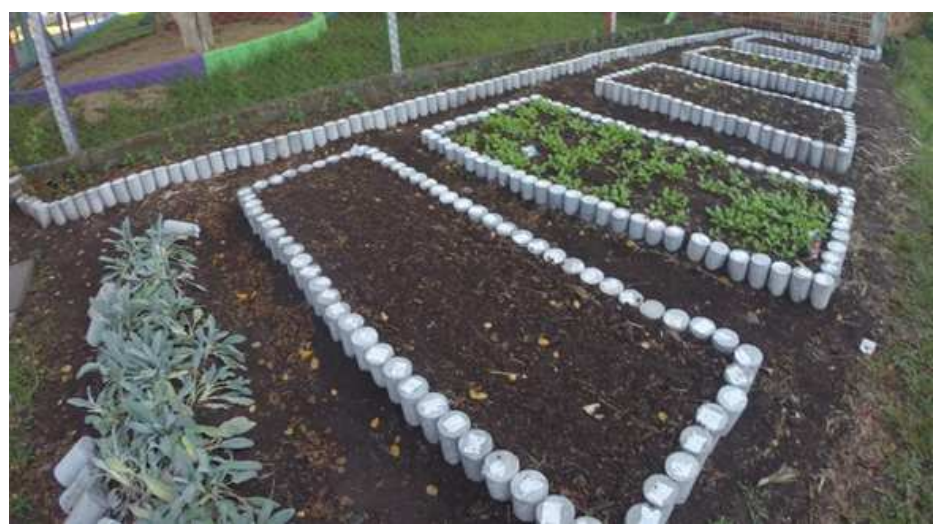

Foto: Arquivo das bolsistas.

Plantaram-se mudas e sementes de diversas origens: parte delas foi comprada em agropecuárias. Entretanto, muitas foram obtidas na própria escola, através de vegetais deixados para semente, neste caso, elaborou-se, com os alunos das séries inicias, uma sementeira utilizando-se potes reaproveitados de iogurte, para o cultivo de mudas, a fim de posteriormente serem plantadas na horta. Assim, durante todo o ano, em cada cultura plantada deixavam-se alguns exemplares sem colher os frutos, para extrair as sementes, produzidas livres de agrotóxicos.

Após a reconstrução dos canteiros, a horta passou a contar com atividades constantes, por isso novas culturas iam sempre sendo incluídas no momento da colheita das que já se encontravam prontas para o consumo. Novos canteiros também foram sendo construídos, conforme a possibilidade de aproveitar um novo espaço disponível. Já as atividades de manutenção ocorreram semanalmente, de acordo com a necessidade, incluindo a retirada de ervas daninhas, afofamento da terra e rega das mudas.

\subsection{Subprojeto 2: Terrário}

A montagem de um terrário é uma prática muito comum no ensino de ciências, por ser eficaz para a identificação de fatores ambientais. O objetivo de incluir esta atividade no projeto da horta escolar foi ressaltar a importância de um ecossistema equilibrado. Essa experiência foi aplicada ao 60 ano, dividindo-se 
a turma em cinco grupos de cinco integrantes e seguindo a metodologia proposta por Faria ${ }^{5}$ [5] com pequenas adaptações à realidade da escola.

Foram aproveitados vidros já disponíveis no laboratório da escola, e as categorias de plantas escolhidas para criar o microambiente foram coletadas no ambiente escolar, incluindo chás, hortaliças, Pteridófitas, suculentas e temperos. Cada grupo ficou responsável pela montagem e posterior estudo de um terrário, completando, semanalmente, uma ficha de observação, que, posteriormente, foi utilizada para a compilação de um relatório. Buscou-se montar terrários diferentes, variando-se as plantas, para ter maior diversidade de resultados e, com isso, tornar a observação mais interessante. O acompanhamento do miniecossistema foi semanal na disciplina de ciências (Figura 2). Os materiais utilizados foram lupas de mão e a ficha de observação disponibilizada pelas bolsistas, para habituar os estudantes a seguirem um roteiro e observar detalhes.

Figura 2 - Grupo de alunos observando seu terrário, para posterior preenchimento da ficha de observação

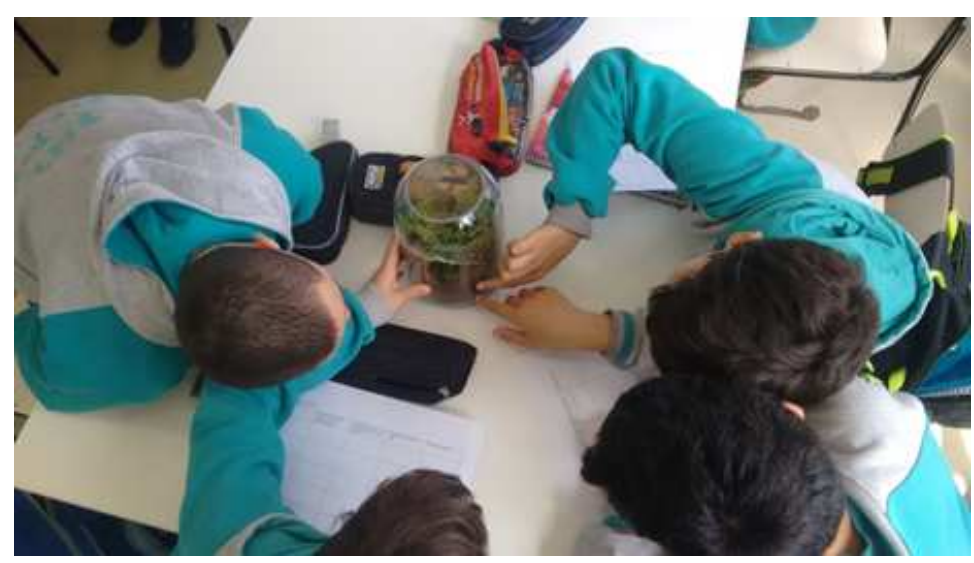

Fonte: Arquivo das bolsistas.

Durante todo o processo, as bolsistas instigavam a curiosidade dos alunos por meio de perguntas sobre o que estava acontecendo e por que estava acontecendo. Após as anotações, os grupos eram instruídos a trocarem seus

\footnotetext{
${ }^{5}$ FARIA, R. Terrário: um ecossistema em miniatura. Ponto Ciência.
} 
terrários, para que pudessem identificar diferenças com os terrários dos outros grupos.

Após seis semanas de observações e anotações, foi dada uma aula sobre a importância de registrar os resultados e montar relatórios para a pesquisa e socialização das informações. Assim, cada aluno elaborou seu relatório com as seguintes partes: capa, introdução, materiais e métodos, resultados, discussões e conclusão, sendo destinado um período de aula para elaboração de cada parte, com orientação das bolsistas e da professora titular. Em especial, os resultados e discussões foram elaborados conjuntamente pela turma, na qual todos puderam incluir suas contribuições individuais.

\subsection{Subprojeto 3: O mundo na nossa horta}

Diante da curiosidade dos alunos sobre a origem de alguns vegetais, percebeu-se a oportunidade de inserir conceitos da biogeografia no cotidiano escolar. O projeto incluiu a confecção de um herbário e o levantamento de informações sobre a região de origem de cada exemplar catalogado.

A turma que desenvolveu esta atividade foi 0 7으 ano, devido à compatibilidade com o conteúdo curricular de ciências naquele período. Os alunos foram divididos em cinco grupos de quatro integrantes. A distribuição das plantas a serem herborizadas foi aleatória, com a utilização das espécies florescidas da horta escolar. Cada grupo ficou responsável por duas plantas. A metodologia utilizada foi baseada em Peixoto, ${ }^{6}$ porém com diversas adaptações ao ambiente escolar e tempo para execução das tarefas. As adaptações mais relevantes foram a secagem das exsicatas - por micro-ondas; o número de amostras - apenas uma; ficha de identificação dos exemplares - com os itens julgados mais relevantes para a faixa etária dos alunos.

O levantamento de informações sobre a região de origem das espécies vegetais foi através da internet, no laboratório de informática da escola, com supervisão das bolsistas do Pibid e da professora titular. Para finalizar o projeto e unificar os conhecimentos, a última tarefa foi a elaboração de um cartaz/mural (Figura 3) com o mapa mundial onde as exsicatas do herbário foram coladas, indicando com setas as suas regiões nativas. $O$ resultado que pode ser visto na

\footnotetext{
${ }^{6}$ PEIXOTO, A. L; MAIA, L. C. (Org.). Manual de procedimentos para herbários. Recife: Ed. da
} UFPE, 2013. 
Figura 3 indica que a maioria das espécies cultivadas em nossas hortas são exóticas e provenientes de diferentes partes do mundo. Além da elaboração do mapa, o último momento do subprojeto foi marcado pela socialização de ideias e discussão dos resultados.

Figura 3 - Mapa construído pelos alunos do 7o ano, identificando o local de origem das plantas trabalhadas no herbário

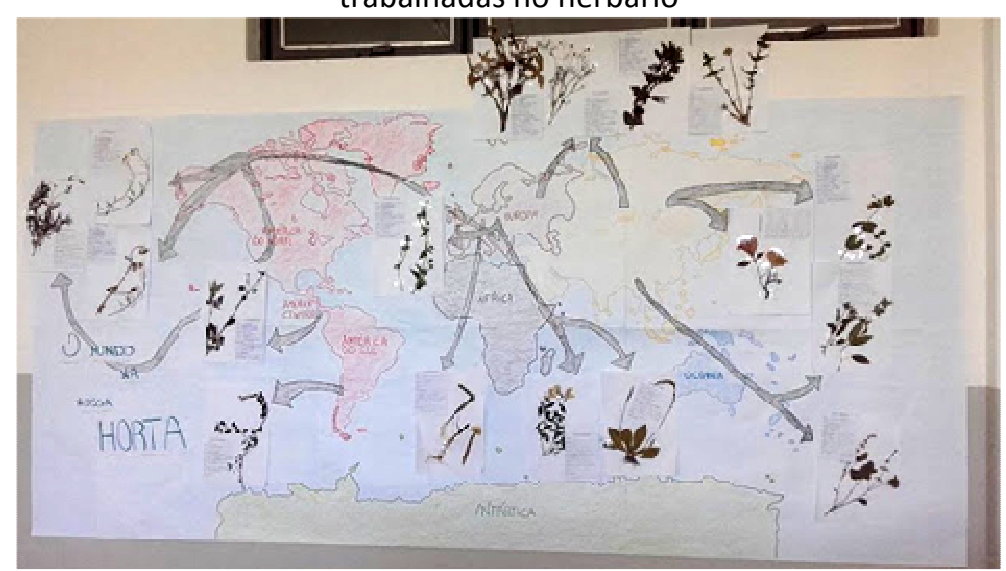

Fonte: Arquivo das bolsistas.

\section{Resultados e discussões}

Os projetos de ensino com a horta escolar perduraram todo o ano de 2016, sempre com novas atividades sendo incluídas, uma vez que um dos pontos relevantes da proposta era sua continuidade, pois não bastava a reconstrução da horta. Era preciso entender o seu funcionamento, principalmente o ciclo de cada vegetal plantado e a diferença no tempo de desenvolvimento das diferentes espécies. Por isso, durante toda a semana, de acordo com as necessidades, os alunos eram envolvidos em atividades de manutenção, plantio ou preparo da terra para novas culturas. Percebeu-se que as tarefas da horta não podem ser realizadas com grupos grandes, pois dificulta a organização dos trabalhos. Devido a essa situação, foi preciso criar uma dinâmica diferenciada, em que parte da turma permanecia na sala, fazendo uma atividade teórica e parte ia para a horta, sempre revezando para que todos pudessem participar e receber a atenção dedicada de quem orientava as atividades. Demo ${ }^{7}$ faz uma crítica ao papel do professor, ao afirmar que é fundamental redefini-lo como quem cuida da

\footnotetext{
${ }^{7}$ DEMO, P. Professor do futuro e reconstrução do conhecimento. Petrópolis: Vozes, 2004.
} 
aprendizagem dos alunos. O termo cuidar também é definido por Boff ${ }^{8}$ como: "mais que um ato; é uma atitude. Portanto, abrange mais que um momento de atenção, de zelo e de desvelo" (p. 33). Esta definição é ampliada pelo mesmo autor em: "[...] a verdadeira essência do ser humano", (p. 46). Por isso, falar em cuidar na educação transcende a simples ação de transmitir conhecimento, reproduzir informações e aplicar técnicas que favoreçam a memorização. É ter a preocupação responsável com o presente e o futuro dos estudantes, com a forma de aprendizagem e com a busca incansável por recursos e modelos que promovam a aprendizagem.

O envolvimento dos alunos com todas as etapas, até chegar ao consumo do alimento, foi essencial para a compreensão do tempo de desenvolvimento dos vegetais e os cuidados necessários para que eles cresçam vigorosos. Essa questão também contribuiu para o incentivo à alimentação saudável, uma vez que $o$ fato de as crianças plantarem o alimento, que seria posteriormente consumido por elas, acabou estimulando-as a consumirem na merenda escolar o que elas mesmas haviam plantado, pois se destinou todo o alimento produzido na horta para o preparo da merenda.

O fato de a escola ser de turno integral e os alunos fazerem todas as refeições nela gera uma grande demanda por alimentos, e os produtos da horta sempre foram bem-vindos na cozinha da escola. O trabalho didático desenvolvido, por sua vez, contribuiu para a mudança de hábitos alimentares já que, antes de sua implementação, havia a dificuldade de incluir verduras e legumes na alimentação escolar dessas crianças.

Além de reconstruir a horta no espaço delimitado inicialmente, com o decorrer das atividades foi-se verificando a possibilidade de fazer mais canteiros em outros locais do pátio, em áreas sem ocupação e adequadas para o plantio. Essa atividade foi interessante para trabalhar a noção de aproveitamento do espaço, visto que muitos tinham a ideia de que, para plantar legumes e verduras, era preciso um terreno com grande área disponível.

Outro aspecto muito positivo é que, durante o desenvolvimento das atividades, os alunos estabeleceram relações com a horta que tinham na sua casa ou de algum familiar e motivaram-se a também participar das atividades de

\footnotetext{
${ }^{8}$ BOFF, L. Saber cuidar: ética do humano: compaixão pela terra. 16. ed. Petrópolis: Vozes, 1999.
} p. 33. 
horta em casa. Então, todas as técnicas aprendidas nas aulas eram possibilidades para aplicar no seu dia a dia. Para outras crianças, especialmente as residentes em apartamentos, as atividades na horta foram momentos únicos, pois relatavam não ter esse tipo de contato com a natureza, especialmente com a terra.

Além disso, alguns conheciam os legumes e as verduras somente quando estavam na mesa ou no mercado; para tais alunos a horta foi um momento essencial de aprendizagem, já que não faziam ideia do processo e do tempo que era necessário para produzir uma beterraba, por exemplo. Sempre que possível, foram utilizadas sementes produzidas pelos centros ecológico-regionais, porém não se conseguiu sementes ecológicas de hortaliças; por isso, o aprendizado de coleta e armazenamento das sementes de hortaliças cultivadas na horta foi importante para os alunos. Cabe ressaltar que as aprendizagens não eram isoladas, pois, além das plantas, estudou-se o solo, ao analisar qual era adequado para o plantio, bem como a importância da água para todos os seres vivos e o ciclo de um vegetal.

O contato direto com o meio natural possibilitou também a educação ambiental, pois fez despertar o interesse para a necessidade do cuidado com a natureza. Acrescente-se a esse ponto a produção das hortaliças com métodos da agricultura ecológica, mostrando para as crianças que é possível cultivar sem fazer uso de agroquímicos.

Foi possível observar, ao longo de todo o ano, que os alunos ficavam entusiasmados sempre que selecionados para irem à horta, e aos poucos foram criando mais gosto pelas atividades externas e pelo contato direto com o meio natural. Pelo fato de os alunos permanecerem na escola o dia todo, chegando ao turno da tarde já cansados do espaço da sala de aula, as tarefas externas eram estimulantes, revigorando as energias antes de retornarem às atividades de sala de aula. E apesar das atividades serem realizadas com certa rotina, elas não se tornaram maçantes, pelo fato de serem cultivadas espécies vegetais com ciclos de desenvolvimento diferentes, a cada semana a horta apresentava novidades.

A elaboração do subprojeto terrário como um todo foi importantíssima para implantar a alfabetização científica nos alunos. Ficou evidenciado, principalmente, na produção dos resultados e das discussões do relatório o quanto foi relevante ter mantido as observações semanais por um período 
considerável. Todos os alunos souberam destacar alguma transformação possível de observar em um miniecossistema, sugerindo, como destacam alguns autores, que o ambiente ativo, dinâmico e construtivo pode influenciar positivamente a percepção de educadores e educandos. ${ }^{9}$

O subprojeto "o mundo na nossa horta" trouxe reflexões importantes, ao evidenciar que a maioria das plantas utilizadas na horta era de origem europeia ou asiática, trazendo reflexões sobre o movimento imigratório e seu papel na cultura regional. Para Vasconcellos ${ }^{10}$ a mobilização para o conhecimento em sala de aula, além das características do sujeito, está relacionada ao tema e à forma como é trabalhado, reforçando a convicção de que a ação dos professores é decisiva, para que os fatos cotidianos sejam ressignificados pela aprendizagem.

\section{Considerações finais}

A reconstrução da horta atingiu os objetivos propostos e disponibilizou um ambiente experimental para o ensino de ciências. Ela também poderá ser reinventada e recriada, pois se trata de um espaço aberto a mudanças, para torná-la sempre mais próxima da realidade dos alunos e para aprimorar seu potencial.

A horta revelou-se um espaço lúdico de aprendizagem, pois percebeu-se que o entusiasmo e o gosto dos alunos pelas atividades foram aumentando progressivamente, bem como o interesse em experimentar e consumir as hortaliças produzidas. Além disso, integrar a horta com atividades paralelas mostrou-se enriquecedor, de maneira que se pode extrair e conectar conhecimentos mais complexos, mesmo diante de turmas do Ensino Fundamental.

A horta, direta ou indiretamente, faz parte do cotidiano dos alunos e os aproxima ainda mais da realidade. Dessa forma, os resultados obtidos sugerem que ela é uma importante ferramenta educacional, caso seja utilizada com criatividade e dinamismo. É relevante ressaltar que esse tipo de atividade pode

\footnotetext{
${ }^{9}$ FARIAS, P. A. M.; MARTIN, A. L.A. R.; CRISTO, C. S. Aprendizagem ativa na educação em saúde: Percurso histórico e aplicações. Revista Brasileira de Educação Médica, Rio de Janeiro, p. 143$158,2015$.

10 VASCONCELLOS, C. S. Construção do conhecimento em sala de aula. 13. ed. São Paulo: Libertad, 2002.
} 
representar um complemento teórico essencial não somente para a área das ciências como também para outras, tornando-se uma possibilidade de colocar em prática a interdisciplinaridade.

\section{Referências}

DORNELES, L. T.; CUNHA, G. F. Biologia vegetal: manual de práticas escolares. Caxias do Sul: Educs, 2005.

CYPRIANO, R. J. et al. Horta escolar: um laboratório vivo. Educação Ambiental em Ação (Artigos), n. 42, 2013.

BARBOSA, N. V. S. A horta escolar dinamizando o currículo da escola. 3. ed. Ministério da Educação, Brasília: Cristal, 2009. Caderno 1.

FERNANDES, M. C. A. Orientações para implantação e implementação da horta escolar. 3. ed. Ministério da Educação, Brasília: Cristal, 2009. Caderno 2.

FARIA, R. Terrário: um ecossistema em miniatura. Ponto Ciência.

PEIXOTO, A. L; MAIA, L. C. (Org.). Manual de procedimentos para herbários. Recife: Ed. da UFPE, 2013.

DEMO, P. Professor do futuro e reconstrução do conhecimento. Petrópolis: Vozes, 2004.

BOFF, L. Saber cuidar: ética do humano: compaixão pela terra. 16. ed. Petrópolis: Vozes, 1999.

FARIAS, P. A. M.; MARTIN, A. L.A. R.; CRISTO, C. S. Aprendizagem ativa na educação em saúde: Percurso histórico e aplicações. Revista Brasileira de Educação Médica, Rio de Janeiro, p. 143-158, 2015.

VASCONCELLOS, C. S. Construção do conhecimento em sala de aula. 13. ed. São Paulo: Libertad, 2002. 
ESTRATÉGIA PRÁTICA PARA ENSINO DE PALEONTOLOGIA

\author{
Willian Lando Czeikoski* \\ willianlandoc@yahoo.com.br \\ Aline de Godoy* \\ alinedegodoy3@gmail.com \\ Kétini Mafalda Sacon Baccin* \\ ketinibaccin@hotmail.com \\ Subprojeto Pibid Biologia-Carvi \\ Escola Estadual de Ensino Médio Mestre Santa Bárbara
}

Resumo: Este artigo discute a importância do ensino da Paleontologia, como parte integrante do Ensino de Ciências e Biologia, como preveem os parâmetros curriculares nacionais (PCN). São apresentados argumentos sobre a relevância dos conhecimentos paleontológicos desde o Ensino Fundamental e é descrita e discutida uma oficina de simulação de produção de fósseis. Os resultados obtidos sugerem que esta é uma ótima prática para trabalhar conceitos básicos sobre o aparecimento e desenvolvimento da vida no planeta Terra, uma vez que apresenta um aspecto lúdico, que favoreceu a aprendizagem com alegria, facilitando a comunicação entre os educandos e os educadores. Em relação à formação docente, esta experiência foi enriquecedora por possibilitar a abordagem de conteúdos complexos de forma didática e atrativa para os alunos, abrindo o leque de possibilidades de estratégias docentes, que viabilizam a aprendizagem ativa e a alfabetização científica.

Palavras-chave: Ensino de Paleontologia. Oficina de fósseis. Aprendizagem ativa.

\title{
Introdução
}

A Paleontologia é uma ciência de caráter interdisciplinar, situada na interface entre as Ciências Biológicas e as Geociências. Suas pesquisas inspiram inúmeras questões sobre a natureza e fornecem subsídios para o envolvimento científico, através da integração de diversos campos do conhecimento. (SOARES, 2015).

Em síntese, a Paleontologia é uma ciência que estuda os animais e vegetais que viveram no passado, através da análise de fósseis. Suas pesquisas buscam, por meio do estudo de fósseis, informações tais como: idade do fóssil, condições

\footnotetext{
* Universidade de Caxias do Sul, graduandos em Ciências Biológicas - Licenciatura, bolsistas Pibid/Capes. Coordenadora do subprojeto Profa. Dra. Gladis Franck da Cunha - Supervisora Profa. Luciana Bonato Lovato.
} 
de vida e morte do ser fossilizado, características e influências ambientais encontradas no passado do planeta Terra. $O$ registro fóssil e o registro arqueológico servem como as principais fontes de evidências para a reconstrução da Pré-História humana, que, em conjunto com técnicas atuais de investigação e datação de fósseis, bem como com experimentos engenhosos, está tornando possível a obtenção de evidências materiais confiáveis para a compreensão da história do homem. (LEWIN, 1999).

Como destaca Soares (2015), em função de seu caráter intrinsicamente interdisciplinar, a Paleontologia, se bem-explorada pedagogicamente, apresenta grande potencial para se constituir em um instrumento facilitador do processo de investigação científica e de transformação de uma visão fragmentada para uma visão integrada da Ciência. De acordo com os PCNs (BRASIL, 1998), os conteúdos abordados em Paleontologia fazem parte do plano curricular de Ciências, nos níveis de Ensino Infantil, Fundamental e Médio. No entanto, esses conteúdos, na maioria das salas de aula, não são bem-explorados, em geral por falta de material didático e métodos de ensino:

\begin{abstract}
Apesar de todo esse potencial pedagógico, sabemos que no nosso país o ensino da paleontologia é subexplorado nos currículos do Ensino Fundamental e Médio, apesar de seus conteúdos integrarem os Parâmetros Curriculares Nacionais (PCN). Isso decorre de uma série de fatores que, provavelmente, têm início na formação paleontológica, em geral, pouco aprofundada dos professores de Ciências, Biologia e Geografia. Mesmo aqueles professores que buscam instrumentalização e atualização se deparam com escasso material sobre o assunto, visto que os livros didáticos de educação básica destinam pouco espaço para questões de cunho paleontológico. (SOARES, 2015, p. 4).
\end{abstract}

Nesse contexto, mesmo quando é abordada em aula, a Paleontologia fica restringida a assuntos como os grandes répteis, dinossauros, em especial pelos livros didáticos (MeLLo et al., 2005; DIAS DA SILVA, S., 1998) e carece de estratégias que abranjam a complexidade deste conteúdo. Quando bem-explorados, os conteúdos de ciências atingem um dos seus principais objetivos, que consiste no desenvolvimento de habilidades e competências que preparem os educandos para as mudanças, enfrentado as novas situações e os desafios que as grandes e complexas transformações vêm operando no mundo contemporâneo, afetando drasticamente o ser humano, o ambiente e as relações entre eles. (CUNHA, 2012). 
Ou seja, parte-se do pressuposto de que, se bem-trabalhada, a Paleontologia contribui para o entendimento do passado e a compreensão de que ocorreram e podem ocorrer profundas transformações na Terra, contribuindo para o aprendizado da ecologia e evolução dos seres vivos. Além disso, os fósseis são imprescindíveis, por exemplo, para a prospecção e exploração de recursos geológicos tão importantes, como o carvão e o petróleo, ou seja, a abordagem mais aprofundada da paleontologia contribui, também, para o desenvolvimento de competências específicas das Ciências Naturais, como a avaliação da disponibilidade e os processos para a obtenção e utilização de recursos materiais e energéticos relacionados à sustentabilidade ambiental. (CUNHA, 2012).

\section{Objetivo}

O presente artigo visa a descrever e refletir sobre uma estratégia de ensino de Paleontologia, que utiliza atividades que exploram os conhecimentos de forma didática e atrativa para os alunos, através de uma oficina de réplica de fósseis.

\section{Referencial teórico}

Através do Programa Pibid, valoriza-se a formação de docentes, dando-lhes oportunidades de experiências metodológicas e práticas com os educandos da rede pública de educação básica, buscando romper a ênfase dada à compartimentalização do conhecimento em disciplinas, por meio de uma ação docente, que promova o desenvolvimento de habilidades e competências, usando os conteúdos como instrumento, mas não como o objetivo central da prática pedagógica. (CUNHA, 2012).

Neste contexto, o professor é considerado um elemento-chave na organização das situações de aprendizagem, pois compete-lhe dar condições para que o aluno aprenda a aprender, pois fará as perguntas que não fazem parte do cotidiano extraescolar, no sentido, por exemplo, de que o ensino de ciências é essencial por tratar de temas que não costumam fazer parte das conversações sociais. Assim, mais do que informar, o professor deverá desafiar 
os alunos a buscarem respostas em diferentes fontes de pesquisa, contribuindo para o desenvolvimento da inteligência como um todo. (CUNHA, 2012)

A partir destes pressupostos, a Paleontologia, pelo seu caráter interdisciplinar e prático, é um instrumento excelente para a construção do conhecimento, desde que, como destacam Mello et al. (2005), ela não fique somente nos livros didáticos, laboratórios ou em exposições, seja instituições ou museus, mas seja utilizada para o ensino de ciências e biologia, como preconizam os PCN. (SOARES, 2015). A deficiência do ensino de Paleontologia nas escolas de educação básica deve ser sanada pelo conhecimento dos atuais profissionais, tornando as informações da vida pretérita local, mais acessíveis à população. Ao mesmo tempo, estimula-se os alunos, tornando-os agentes multiplicadores dessa área de estudo.

Em especial, a compreensão sobre os fósseis leva à compreensão de que a Paleontologia é uma ciência que resulta da atividade humana, e os conhecimentos científicos estão a serviço da humanidade. Nesse sentido, o paleontólogo é o cientista que estuda a vida pré-histórica, a partir das evidências fornecidas pelos fósseis e pelas rochas, mas nesta profissão existem especializações, tais como: os Paleozoólogos, que são os especializados em fósseis animais; os Paleobotânicos, que estudam as plantas fósseis, e os Micropaleontólogos, que estudam fósseis microscópicos, ou seja, microorganismos fósseis de parede orgânica (por exemplo: pólens) ou mineralizada (por exemplo: foraminíferos). (SIMÕES et al., 2015). Nesta perspectiva, elaborouse uma oficina de réplica de fósseis, na qual os educandos participassem fazendo suas próprias cópias e entendessem os elaborados processos para a formação de um fóssil.

\section{Metodologia}

A oficina dos fósseis foi desenvolvida na Escola Estadual de Ensino Médio Mestre Santa Bárbara, localizada no Município de Bento Gonçalves - RS, com três turmas de 7ạ ano, contabilizando 75 alunos, com idade entre 12 e 13 anos. $^{1}$

\footnotetext{
${ }^{1}$ Todos os alunos participantes têm autorização assinada pelos pais permitindo o uso de suas imagens nas divulgações das atividades desenvolvidas pela EEEM Mestre Santa Bárbara de Bento Gonçalves - RS.
} 
Esta oficina foi dividida em dois momentos: parte teórica e parte prática, englobando duas semanas de aula, com quatro períodos em cada turma. No primeiro contato com os estudantes, houve a introdução dos conteúdos sobre Paleontologia, abrangendo pontos importantes da história do planeta Terra, a evolução dos organismos e curiosidades diversas. Após o término da explicação, pediu-se aos estudantes que realizassem grupos para uma atividade didática de confecção da uma linha geológica, contendo cinco metros de comprimento (Figura1).

Figura 1 - Atividade dinâmica da linha geológica sendo realizada

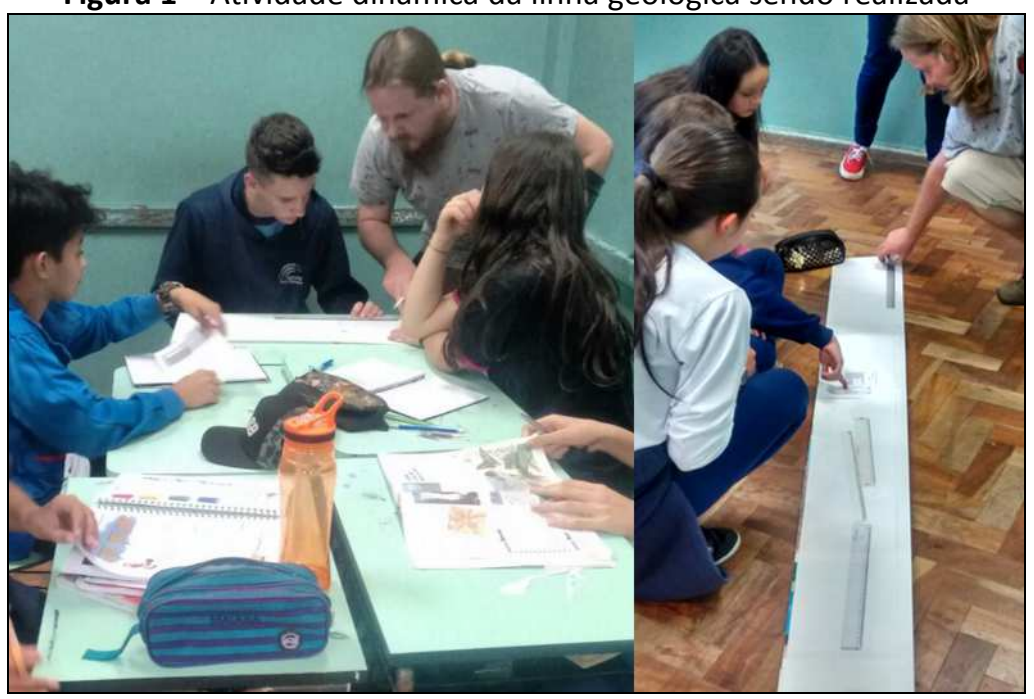

Fonte: Arquivo das bolsistas.

Na segunda semana foi realizada a prática de simulação da "produção de fósseis" com gesso, que ocorreu a céu aberto, na área de recreação da escola, uma vez que envolvia a coleta de materiais a serem fossilizados. Solicitou-se aos alunos que trouxessem recipientes, como, por exemplo, caixas de fósforo e copos de iogurte, nos quais o gesso líquido seria alocado para a "impressão do fóssil".

Posteriormente, a tarefa dos estudantes era encontrar no pátio da escola alguma folha, para realizar o vestígio de suas nervuras. Além disso, foram disponibilizadas, pelos bolsistas, conchas para outros exemplares (Figura 2). Também foi demonstrado aos alunos como as réplicas dos fósseis são feitas com gesso no molde de silicone. 
Figura 2 - Impressões de folhas e conchas no gesso

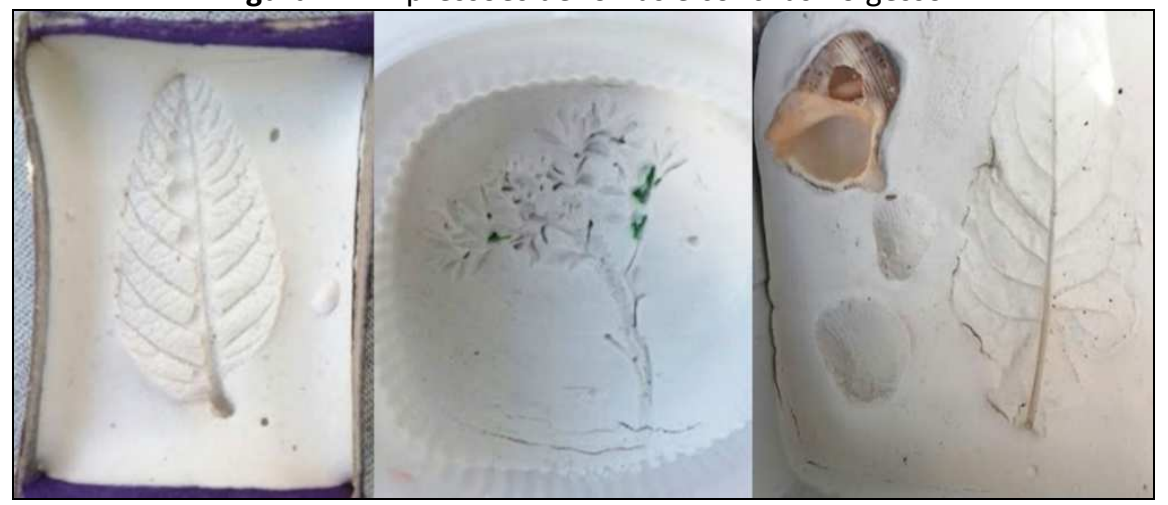

Fonte: Arquivo das bolsistas.

Durante a realização desta prática, é importante retomar a informação teórica de que o evento de fossilização é um fenômeno natural, que envolve diversos processos biológicos, físicos e químicos, que, literalmente, promovem a passagem dos restos orgânicos da Biosfera para a Litosfera e podem consistir em restos ou vestígios (traços) de animais, vegetais e de outros micro-organismos (algas, fungos e bactérias). (SIMÕES et al., 2015). Além disso, convém destacar que este experimento simula a formação de um dos tipos de fósseis, que são os "moldes". Para o surgimento de um molde, durante a litificação, as camadas de sedimentos que contêm os restos dos organismos (ex.: conchas) podem preservar a forma desses restos, mesmo depois que os mesmos tenham sido totalmente destruídos. Assim, uma concha pode ser totalmente dissolvida, porém poderá deixar o seu molde na rocha sedimentar. Se a concha estiver preenchida internamente por sedimentos, o molde resultante será denominado de Molde Interno. (VEgA et al., 2015).

No final da atividade, realizou-se um Quiz, sobre os conteúdos vistos, a partir do qual os alunos, que respondessem corretamente o maior número de questões, seriam contemplados com um modelo de fóssil, produzido pelos bolsistas no laboratório de Geologia e Paleontologia do Carvi-UCS (Figura 3), que possui em seu acervo fósseis verdadeiros, que podem ser utilizados para a produção de réplicas e constituírem material didático para estudo da Paleontologia. Entre os brindes, havia impressões de Trilobita, Serpente-do-mar, vértebra de Mesossauro, dentre outros. 
Figura 3 - Modelos de fósseis no gesso dados de brinde como reconhecimento ao mérito dos estudantes

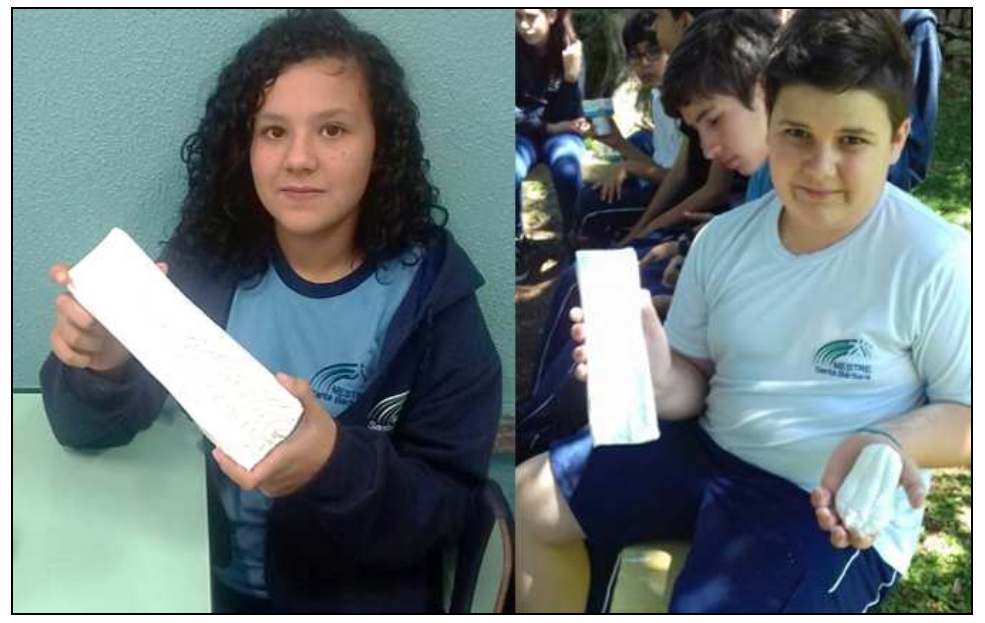

Fonte: Arquivo das bolsistas.

\section{Resultados e discussão}

O processo de fossilização não ocorre de uma hora para outra e pode durar milhares de anos. Portanto, ainda não podemos fabricar um "fóssil em laboratório" (VEGA et al., 2015), mas a simulação do processo de fossilização é uma atividade lúdica, que pode utilizar materiais de baixo custo e não tóxicos disponíveis no mercado, como o gesso, possibilitando a compreensão de um evento complexo, que ocorre naturalmente.

Como explica Heirich et al. (2015), a Paleontologia faz parte do currículo das disciplinas de Ciências e Biologia, e há uma falta de recursos, para que sejam trabalhados estes conceitos, o que foi percebido no projeto aqui apresentado.

Os alunos não tinham um conhecimento aprofundado do tema nem tinham elementos conceituais, para compreender a noção do tempo decorrido desde o surgimento da Terra. Dessa forma, as atividades práticas foram importantes e pertinentes para produzir conhecimentos que possibilitassem o estabelecimento de relações com as informações científicas presentes nos livros didáticos. Assim, quando foi construída uma linha do tempo em escala de 1:10 milhões, os alunos puderam ter uma noção visual do curto espaço de tempo em que o ser humano está inserido na vida da Terra, em comparação com outros organismos, como as bactérias. Conseguiram, também, compreender a noção de Eras, e como estas são definidas. Tais conhecimentos são importantes para a 
compreensão do conceito de sucessão biológica e das transformações da biodiversidade ao longo do tempo, desde o surgimento dos primeiros seres vivos em nosso Planeta.

Foi notório o fascínio dos alunos ao executarem os experimentos em gesso, que simulavam a formação dos fósseis de impressão ou moldes. Todos, sem exceção, executaram as atividades e compreenderam os conceitos sobre fósseis, além de terem demonstrado que gostaram das práticas sugeridas, como, por exemplo, um aluno disse a um bolsista: "Que legal, não sabia que a vida tinha surgido a tanto tempo atrás".

Além disso, as atividades foram importantes para que os alunos pudessem ter noção de evolução, e como nós, seres humanos, temos ancestrais comuns com outros seres vivos da Terra, incluindo as plantas.

\section{Considerações finais}

Atividades de cunho científico, que envolvem conceitos complicados para se entender, são importantes, porém precisam ser trabalhadas de forma prática também, e não somente por meio da exposição oral ou leitura dos conteúdos em livros, revistas ou internet. Desta forma, as atividades foram relevantes para a construção de subsídios conceituais iniciais, por meio da compreensão do que sejam os fósseis e a importância do seu estudo, uma vez que tais subsídios permitirão aos alunos compreenderem elaborações teóricas complexas, como a origem e evolução da vida.

Além disso, é preciso destacar o caráter lúdico desta atividade, como um instrumento importante da alfabetização científica, uma vez que contribui para a alegria em estar na escola e aprender sobre o mundo e de interagir com o outro. O querer estar na escola é um requisito essencial para a construção do conhecimento, pois, como destaca Cunha (2007), a transformação dos educandos em sujeitos que constroem saberes, requer um ambiente pedagógico que possibilite a atividade, desenvolva a análise crítica, o debate coletivo, a elaboração de hipóteses de trabalho e a curiosidade, pois todos estes elementos são essenciais para o desenvolvimento do pensamento científico. 


\section{Referências}

BRASIL. Secretaria de Educação Fundamental. Parâmetros Curriculares Nacionais. Brasília: MEC/SEF. Livro 1, 1998.

CUNHA, G. F. Percepção de mundo e educação do olhar. Blog Teliga.net (TAG: Tese em Educação) 2007. Disponível em: <http://www.teliga.net/2007/10/percepo-de-mundo-eeducao-do-olhar.html\#more>. Acesso em: 28 jan. 2018.

CUNHA, G. F. Referenciais curriculares de ciências. Prefeitura Municipal de Farroupilha; Secretaria Municipal de Educação, Cultura e Desporto. CORAG: Porto Alegre, 2012. p. 167-205.

DIAS DA SILVA, Sérgio. A paleontologia nos livros didáticos de 10 grau: um estudo qualitativo. Acta Geologica Leopoldinensia, São Leopoldo, v. 21, n. 46-47, p. 237-242, 1998.

HEIRICH, Carla Maria et al. O aprendizado da paleontologia no Ensino Básico da cidade de Tibagi PR. Paleo RS/SC, 2015. Disponível em:

<https://www.researchgate.net/profile/Elvio_Bosetti/publication/284720206_O_apren dizado_da_Paleontologia_no_Ensino_Basico_da_cidade_de_Tibagi_PR/links/56571de90 8ae4988a7b52776/O-aprendizado-da-Paleontologia-no-Ensino-Basico-da-cidade-deTibagi-PR.pdf>. Acesso em: 10 jan. 2018.

LEWIN, R. Evolução humana. São Paulo: Ateneu, 1999.

MELLO, Fernanda Torello de; MELLO, Luiz Henrique Cruz de; TORELLO, Maria Beatriz de Freitas. A paleontologia na educação infantil: alfabetizando e construindo o conhecimento. Ciência \& Educação, v. 11, n. 3, p. 395-410, 2005.

SIMÕES, M. G.; RODRIGUES, S. C.; SOARES, M. B. Introdução ao estudo da paleontologia. In: SOARES, M. B. (Org.). A paleontologia na sala de aula. (e-book). Ribeirão Preto: Sociedade Brasileira de Paleontologia, 2015. Disponível em: $<$ https://drive.google.com/file/d/OB2mK57ObVQY3Y2x1c051NEhuanM/view>. Acesso em: 28 jan. 2018.

SOARES, M. B. (Org.) A paleontologia na sala de aula. (e-book). Ribeirão Preto: Sociedade Brasileira de Paleontologia, 2015. Disponível em: $<$ https://drive.google.com/file/d/OB2mK57ObVQY3Y2x1c051NEhuanM/view>. Acesso em: 28 jan. 2018.

VEGA, C. S.; DIAS, E. V.; RODRIGUES, S. C. Fósseis e processos de fossilização. In: SOARES, M. B. (Org.). A paleontologia na sala de aula. (e-book). Ribeirão Preto: Sociedade Brasileira de Paleontologia, 2015. 


\title{
O PIBID-BIOLOGIA NA REVITALIZAÇÃO DOS LABORATÓRIOS NAS ESCOLAS PARCEIRAS
}

\author{
Luciana Bonato Lovato ${ }^{1}$ \\ lublovato@yahoo.com.br \\ Ana Paula de Souza ${ }^{2}$ \\ pallisana03@gmail.com \\ Bruna Trevisol Dupont ${ }^{2}$ \\ btrevisol@ucs.br \\ Raquel de Villa ${ }^{2}$ \\ Raquel.devilla@gmail.com \\ Dra. Gladis Franck da Cunha ${ }^{3}$ \\ gfcunha2@ucs.br
}

Subprojeto Pibid Biologia - Carvi-UCS

Escola Estadual de Ensino Médio Mestre Santa Bárbara

Resumo: O Laboratório de Ciências é um espaço educativo fundamental para o desenvolvimento de atividades práticas e, para isso, ele precisa ter uma adequada organização do seu espaço e dos equipamentos, além de roteiros de práticas que auxiliem o professor a preparar suas aulas, bem como uma articulação entre professores de ciências e bolsistas para a oferta de atividades práticas ao maior número de turmas. Nesse sentido, uma das principais atividades do subprojeto do Pibid Ciências Biológicas do Campus Universitário da Região dos Vinhedos, da Universidade de Caxias do Sul, desde 2014, tem sido os projetos de revitalização dos Laboratórios de Ciências nas escolas parceiras. Como resultados das ações dos bolsistas, muitos professores puderam oferecer aulas práticas que contribuíram para o estabelecimento de relações entre os conceitos teóricos e os eventos práticos que permeiam o cotidiano. Os relatos dos bolsistas apontam que estas ações do Pibid qualificam a iniciação à docência, desenvolvendo habilidades para a elaboração de planos de ensino e de aulas, que privilegiem a aprendizagem ativa das ciências naturais.

Palavras-chave: Revitalização de laboratório. Aulas práticas. Ensino de ciências e biologia.

\section{Introdução}

As vivências escolares, quando significativas, ocasionam mudanças comportamentais internas nos estudantes, direcionando suas ações às novas situações de aprendizagem baseadas na curiosidade e na descoberta. As atividades experimentais objetivam promover interações sociais, que tornem as explicações mais acessíveis e eficientes. (GASPAR, 2009). Segundo Penin e

\footnotetext{
${ }^{1}$ Supervisora Pibid/EEEM Mestre Santa Bárbara.

${ }^{2}$ Bolsista de Iniciação à Docência Pibid-Biologia-Carvi.

${ }^{3}$ Coordenadora do subprojeto Pibid-Biologia-Carvi.
} 
Vasconcellos (1994; 1995 apud DEMO, 2011), a aula que apenas repassa conhecimento não sai do ponto de partida e, na prática, atrapalha o aluno, porque o deixa como objeto de ensino e instrução. Vira treinamento. Nesta perspectiva, a junção de teoria e prática torna as aulas atrativas e desafiadoras, favorecendo o processo de ensino e aprendizagem, transformando o aluno em sujeito da ação de aprender. Em se tratando de Ensino de Ciências, as atividades práticas são essenciais nesse processo, pois, de acordo com Capeletto (1992), as aulas práticas são estratégias para que o discente comprove o que aprendeu na teoria, desenvolvendo habilidades investigativas e construindo, assim, seu conhecimento.

O processo investigativo em Ciências se faz por meio de experimentos, de práticas educativas, mas tais ações não se baseiam apenas em chegar e fazer, mas na formulação de uma situação-problema para que os estudantes adquiram um sentido racional, para que possam questionar, discutir, formular hipóteses e analisar ou descrever dados. Esta conduta está baseada nas orientações da Unesco, quanto ao dever do professor de estimular o desenvolvimento de competências "através do uso das quatro premissas como eixos estruturais da educação na sociedade contemporânea: aprender a conhecer, aprender a fazer, aprender a viver e aprender a ser". (UNESCO, 2000, s/p). No mesmo sentido, os Parâmetros Curriculares Nacionais (PCN) para o ensino de Ciências e de Biologia (BRASIL, 2000) afirmam a necessidade de proporcionar aos estudantes a capacidade de pesquisar, buscar informações, analisá-las e selecioná-las, colocando em prática conceitos desenvolvidos na escola, em vez de realizar simples exercícios de memorização.

Com base nesses pressupostos, as atividades do subprojeto Pibid Ciências Biológicas, do Campus Universitário da Região dos Vinhedos da Universidade de Caxias do Sul, teve como principal objetivo tornar o espaço do laboratório escolar adequado e atrativo para aulas práticas, além de elaborar protocolos de práticas para seu acervo, possibilitando que outros professores pudessem realizá-las. Nesse sentido, este artigo visou a contextualizar, refletir e descrever os projetos mais significativos relacionados às práticas de laboratório para o ensino de ciências ou biologia realizadas. 


\section{Metodologia}

Esta pesquisa foi de natureza aplicada e apresenta abordagem qualitativa, pois busca descrever e refletir sobre o projeto desenvolvido e seu papel na formação docente. Do ponto de vista de seus objetivos, é explicativa, e quanto aos procedimentos técnicos é pesquisa participante, pois, segundo Thiollent (1985, p. 14), trata-se de "um tipo de pesquisa com base empírica que é concebida e realizada em estreita associação com uma ação ou com a resolução de um problema coletivo e no qual os pesquisadores e participantes representativos da situação ou do problema estão envolvidos de modo cooperativo ou participativo". Do ponto de vista experimental, é um projeto de revitalização de Laboratórios de Ciências. O início das atividades foi de observação e coleta de dados; para tal foram analisadas quatro escolas, sendo duas da rede estadual de ensino e duas da rede municipal, porém a prática de revitalização ocorre, de fato, no Laboratório de Ciências da Escola Estadual de Ensino Médio Mestre Santa Bárbara, que foi parceira do Pibid em 2017.

A primeira etapa para a implementação do projeto constituiu-se na avaliação do espaço físico e no levantamento dos materiais e equipamentos disponíveis nos laboratórios de ciências das escolas parceiras. Nessa, pôde-se verificar que as escolas estaduais tinham um amplo laboratório para a realização das aulas práticas de Ciências e Biologia; porém, nas escolas municipais, em uma havia um espaço restrito para tais atividades e, na outra, não havia local para práticas de laboratório.

Em uma das escolas, que não era o foco de atuação do projeto, foram encontrados microscópios novos, que estavam ainda encaixotados. A ação nesse local foi a montagem dos mesmos, adequando-os ao uso. Nas escolas municipais, onde o espaço era restrito ou ausente, foi priorizada a elaboração de protocolos de práticas para serem realizadas em sala de aula, bem como a revitalização de espaços destinados à horta escolar e/ou também implementação de um aquário e suas práticas relacionadas à educação ambiental, partindo-se de Von Linsingen (2010), para quem o ideal é articular as diferentes abordagens, de acordo com a situação de ensino.

O projeto de revitalização teve início em janeiro de 2017, e durou até março do mesmo ano. A primeira ação realizada foi a limpeza e organização do local, além da etiquetação de bancadas, troca e acréscimo de fixador (álcool 70\%) aos exemplares biológicos, para manter sua preservação e fixação, 
tornando-os adequados para posterior utilização, conforme demonstrado na Figura 1. Também se realizou limpeza de microscópios e verificação de validade de reagentes. Enfim, uma série de atividades que permitiu reorganizar o local para que subsequentemente pudessem ser realizadas atividades práticas. As atividades de inventário dos reagentes químicos, bem como a maneira correta de armazená-los foi realizada com o assessoramento de uma das técnicas responsáveis pelos laboratórios do Campus Universitário da Região dos Vinhedos, da Universidade de Caxias do Sul (Carvi/UCS), a fim de identificarmos a presença de reagentes com prazo de validade vencido ou perigosos. Os reagentes impróprios para uso foram recolhidos pela Secretaria do Meio Ambiente de Bento Gonçalves, que realizou o descarte adequado.

Figura 1 - (A) exemplares que necessitavam da troca do fixador; (B) exemplares após a troca do álcool $70 \%$

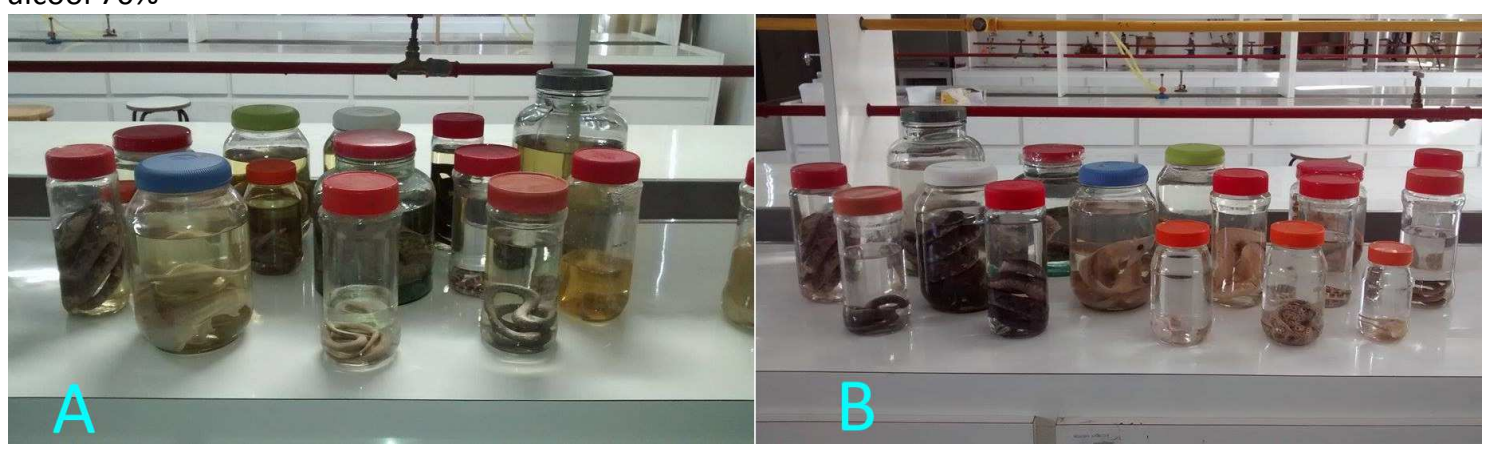

Fonte: Arquivo das bolsistas.

Encerrada a primeira etapa, chegou o momento de dar a devida funcionalidade ao laboratório; para tal, foram planejadas aulas práticas de Ciências ou Biologia, que tiveram o auxílio das professoras supervisoras do Pibid, que tiveram a incumbência de organizar os horários e a definição de temas com os demais professores das disciplinas de Ciências ou Biologia, para, posteriormente, as bolsistas aplicarem as atividades práticas. As atividades elaboradas, levando em conta a realidade de cada turma, que variava desde o 60 ano do Ensino Fundamental até o 3 o ano do Ensino Médio, tiveram por objetivo avaliar os conhecimentos prévios dos alunos e retomar conceitos trabalhados em aula, além de promover a interação entre os estudantes e as bolsistas, relacionando os conteúdos com o cotidiano. 
Tais atividades foram elaboradas, baseando-se nos resultados das reflexões sobre as práticas docentes obtidas com as experiências anteriores, incluindo as dos bolsistas realizadas com o projeto LABCI. (FrANTZ et al., 2015).

Cada prática envolveu o preparo dos materiais necessários e, após, a limpeza de vidrarias, montagem de equipamentos e separação de materiais (reagentes, exemplares biológicos, entre outros), para a realização das atividades.

Para cada ano do Ensino Fundamental foram abordados temas específicos: 60 ano: mudanças de estados físicos da água, sensação térmica, capacidade de dissolução, misturas, densidade e ciclo hidrológico, através da construção de terrário; 70 ano: citologia, processos energéticos, fósseis e visualização, identificação e representação de artrópodes, através do uso de origamis; 8o ano: citologia e alimentação saudável; 9 ano: mudanças de estados físicos da água, sensação térmica, atrito, ácido e base, reações químicas, vasos condutores vegetais. No Ensino Médio foram realizadas práticas sobre Biologia, Química e Física: bioquímica celular, transportes celulares (difusão e osmose), sistema cardiovascular e respiratório, ácido e base (1ํano EM); produção de álcool-gel, sabonete líquido e aromatizante, reações químicas (2ㅇ ano EM); placas bacterianas, atrito (3ㅇa ano $\mathrm{EM}$ ).

Para análise de resultados foram utilizadas descrições das práticas em publicações do Blog do Pibid - Biologia Bento Gonçalves, ${ }^{4}$ que já possui mais de 30 mil visualizações de página, bem como relatos escritos das vivências dos bolsistas envolvidos no projeto. Em relação às publicações do blog serão utilizados os dados sobre o número de alunos e quais turmas foram atendidas.

Já em relação aos relatos dos bolsistas, ${ }^{5}$ será realizada uma análise do conteúdo (AC) na qual "o texto é um meio de expressão do sujeito, onde o analista busca categorizar as unidades de texto (palavras ou frases) que se repetem, inferindo uma expressão que as representem". Em resumo, a AC espera compreender o pensamento do sujeito através do conteúdo expresso no texto, numa concepção transparente de linguagem. (CAREgnATO; MUTTI, 2006).

\footnotetext{
${ }^{4}$ As publicações do blog podem ser acessadas.

${ }^{5}$ Estes relatos podem ser lidos na íntegra, nas publicações do blog dentro da categoria relatos dos bolsistas.
} 


\section{Resultados e discussão}

As experiências vivenciadas durante a participação na reativação das práticas laboratoriais de Ciências e Biologia estão comentadas no decorrer deste artigo, destacando a importância da atuação no Pibid, para a formação à docência.

O inventário dos reagentes químicos resultou em importantes ações de saúde pública e ambiental, uma vez que havia alguns reagentes perigosos armazenados em recipientes e locais inadequados. Verificou-se que havia ácidos e bases fortes que não poderiam ser utilizados sem instalações e instrumentação adequadas, podendo causar acidentes graves. Em especial, havia um grande frasco de mercúrio metálico, guardado em um pote no interior de uma estufa. Neste caso, se por acidente alguém tivesse ligado a estufa e este material vaporizasse, poderia ocasionar a morte de professores e alunos. Muitos destes reagentes devem ter sido adquiridos antes da legislação vigente, pois os mesmos não são mais vendidos para pessoas físicas, apenas para laboratórios com responsável técnico autorizado. O mesmo vale para descarte, que deve ser supervisionado por responsáveis técnicos autorizados. A Figura 2 mostra uma parte do material selecionado para descarte e seu encaminhamento para o mesmo. Esta ação foi indispensável para possibilitar o ingresso seguro dos estudantes nas dependências do Laboratório de Ciências da escola, sem o perigo de acidentes pessoais ou ambientais. No laboratório foram mantidos apenas reagentes não perigosos.

Figura 2 - (A) reagentes vencidos ou perigosos separados para descarte; (B) 4 contêineres com reagentes acondicionados em veículo da vigilância sanitária para o adequado descarte

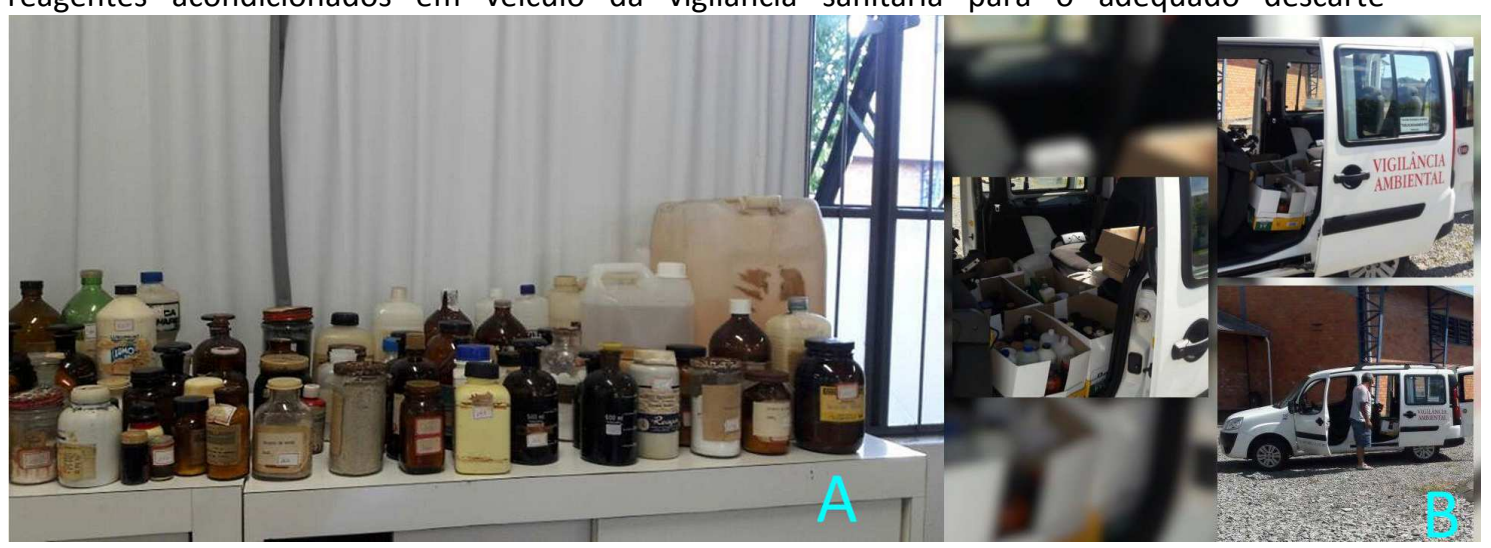

Fonte: Arquivo das bolsistas. 
Para os bolsistas, esta experiência foi bastante relevante, pois, como destaca Andrade,
a responsabilidade pelo planejamento da segurança em um laboratório cabe, exclusivamente, ao pessoal encarregado dos trabalhos docentes e experimentais. [...] É dever dos professores responsáveis pelas atividades de laboratório instruir o pessoal técnico e verificar periodicamente (a cada seis meses, por exemplo) todos os aspectos relacionados à segurança, incluindo instalações e equipamentos, assim como redigir relatórios com as observações realizadas. (2008, p. 12).

Assim, foram mantidos no laboratório e elaborados experimentos utilizando-se apenas reagentes não perigosos, ${ }^{6}$ que dispensam a necessidade de equipamentos de segurança individual (EPI), uma vez que práticas com equipamentos e reagentes especiais são oferecidas, gratuitamente, às escolas pelo projeto $\mathrm{LABCl}$ do Carvi-UCS. A troca do fixador no acervo de animais preservados também foi uma ação importante para possibilitar a realização de práticas de observação de organismos animais, os quais, quando mantidos em adequadas condições de manutenção, podem ser utilizados por anos e servem para desenvolver habilidades de observação e descrição de detalhes anatômicos, as quais não são contempladas pela simples observação de imagens em livros didáticos. Atualmente, há uma extensa legislação sobre a captura de animais silvestres para uso didático, de forma que a correta manutenção deste tipo de acervo é, também, importante para a formação de professores, pois, como destacam Silva et al. (2011, p. 2), "uma maneira de trabalhar o conteúdo programático de zoologia é realizar aulas práticas de laboratório, uma vez que desenvolvendo essa atividade a aula torna-se mais atrativa e de extrema importância para a formação do professor de biologia e ciências".

As práticas possíveis de serem realizadas na escola atenderam 450 alunos dos três anos do Ensino Médio (EM), mais 340 alunos do 6으 ao 9o ano do Ensino Fundamental (EF). Na figura 3 podem ser observados alguns momentos destas práticas. $^{7}$

\footnotetext{
${ }^{6}$ Estes regentes foram todos acondicionados adequadamente e etiquetados.

${ }^{7}$ Todos os alunos da Escola Estadual de Ensino Médio Mestre Santa Bárbara têm um documento assinado pelos pais autorizando o uso de imagem.
} 
Figura 3 - Alunos participando de aulas práticas no laboratório de ciências da escola: A) experimento da lâmpada de java; B) experimento sobre temperatura e sensação térmica; C) experimento sobre xilema; D) prática de anatomia do coração; E) preparação do aquário para futura inserção de peixes

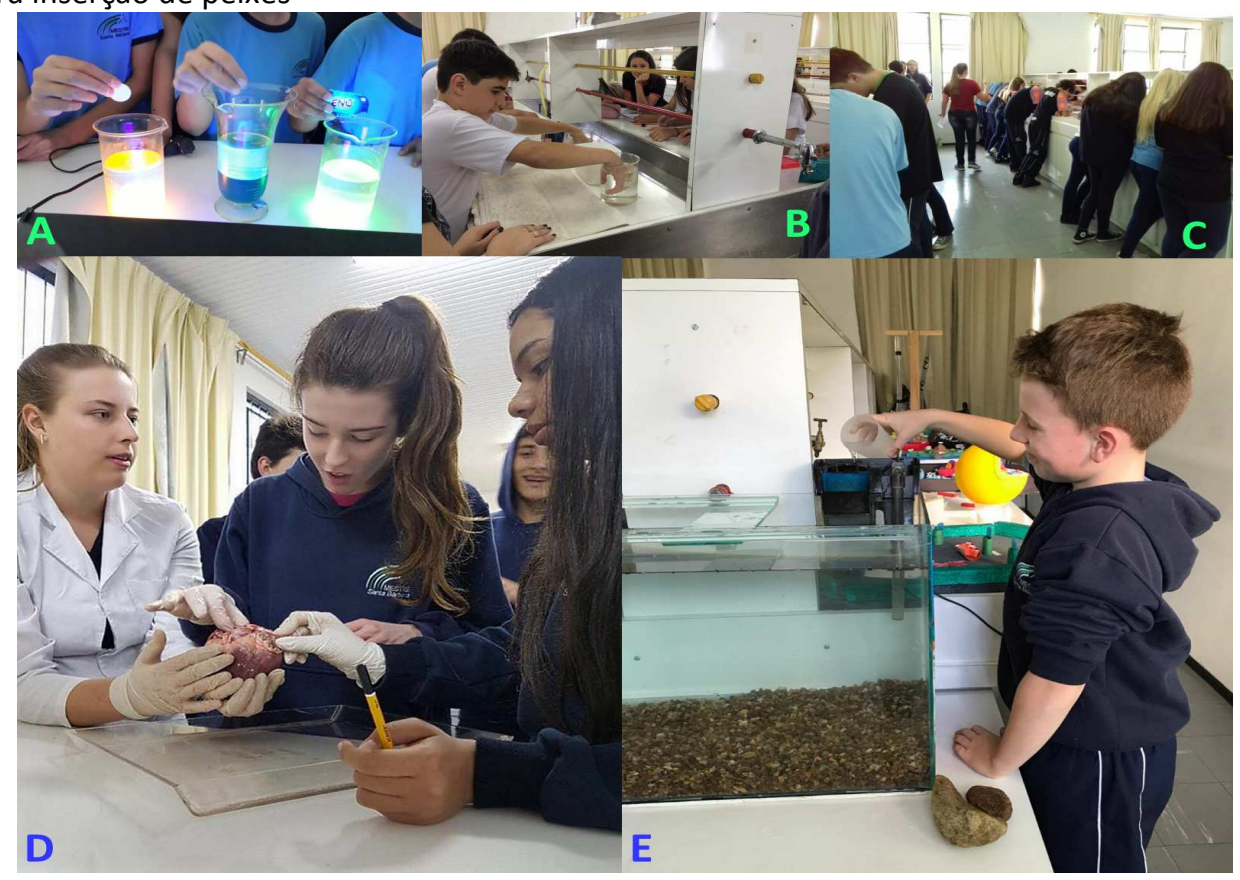

Fonte: Arquivo das bolsistas.

Ao todo, 790 alunos da escola tiveram a oportunidade de realizar uma ou mais aulas práticas no laboratório de ciências da escola que possui, ao todo, mais de mil alunos. Ou seja, mais de $50 \%$ dos alunos tiveram aulas práticas, indicando a importância que este projeto de revitalização teve para a dinâmica da escola. Cabe destacar que o repertório de práticas teve maior aproximação com os conteúdos do 60 ano (EF) e com os conteúdos do 10 ano do EM, de forma que estas turmas realizaram mais práticas. Além disso, como os bolsistas tiveram oportunidade de atender algumas turmas de 10 EM noturno, ao total houve a participação de 270 alunos desta série. Estes dados confirmam a importância de a supervisora do Pibid estabelecer conexões entre os bolsistas com os demais professores da escola, pois, neste contexto, um número bem maior de alunos pode se beneficiar da sua atuação como monitores. Em contrapartida, estes bolsistas desenvolvem habilidades e competências para a realização deste tipo de aula.

Contudo, é preciso ressaltar que, sem a atuação do Pibid na escola, mesmo com o fornecimento de protocolos de aulas práticas, este ritmo talvez não 
consiga ser mantido, e o laboratório volte a ser subutilizado, pois, infelizmente, na maioria das escolas brasileiras, é comum encontrar laboratórios abandonados, talvez pelo desuso ocasionado pela falta de realização de práticas nas disciplinas pelos professores titulares. (LABURú et al., 2007). Entre as prováveis causas deste abandono, pode-se sugerir a falta de carga horária destinada aos professores para a preparação das aulas práticas, as quais demandam bastante tempo e estudo. Além disso, nas ações do Pibid a grande maioria das atividades práticas foi sempre realizada com a participação de dois ou mais bolsistas, que davam atendimento mais próximo aos estudantes, a fim de manter a ordem e os cuidados necessários para o correto uso de equipamentos ou reagentes. (Figura $3-D$ ).

Todos os relatos dos bolsistas destacaram a importância que a elaboração e aplicação de atividades práticas de laboratório têm para a formação dos docentes que atuarão com o Ensino de Ciências ou Biologia, uma vez que este tipo de atividade possibilita o estabelecimento de relações entre os conteúdos teóricos e o mundo natural e dá aos alunos o papel de protagonistas no processo de ensino e aprendizagem. Nesse sentido, Moraes (2004) destaca que ensinar implica a criação de circunstâncias ou de situações que possibilitem vivenciar experiências, para que a aprendizagem se desenvolva, por meio de ações que permitam a troca de experiências e a construção da autonomia dos discentes.

Outro aspecto importante ressaltado pelos bolsistas foi que as atividades desenvolvidas proporcionaram maior integração entre os bolsistas e o conhecimento de diferentes realidades, por meio do contato e da interação com diferentes turmas, possibilitando adequação de conteúdos e atividades, de acordo com as necessidades encontradas.

As aulas laboratoriais, conforme relato dos bolsistas, são ambientes propícios para a troca de experiências, socialização e interação, que irão desenvolver diversas atividades e ações, que proporcionarão o desenvolvimento de diversas habilidades, gerando a construção de conhecimentos Barcelos (2006) coloca que o processo de socialização, inerente à aprendizagem, tem muito mais chances de acontecer no amor, de forma que, ao assumir a condição de ser racional, o professor não deve nem pode anular, obscurecer ou secundarizar a condição de ser emocional. 
Como um todo, o fato de ter participado de um projeto como o Pibid foi percebido como um grande exercício prático para sua formação docente, na perspectiva de que, para compreender a teoria, é preciso experiênciá-la (FrEIRE, 1997), pois as atividades práticas favorecem os questionamentos e, segundo Freire e Faundez (1985, p. 48), "a origem do conhecimento está no ato de perguntar", ou seja, a pergunta desperta a curiosidade e a crítica e, consequentemente, acaba aprimorando a maneira de pensar, imaginar e criar, como resultado do exercício de diferentes habilidades e competências. Ainda segundo o educador, todo o conhecimento começa pela pergunta e pela curiosidade, que muito frequentemente se expressa na forma de uma pergunta. "É na pergunta que está o interesse, ou a fome pelo conhecimento necessário para nutrir o pensamento na busca de significados".

Neste contexto a atuação da supervisora da escola é essencial ao proporcionar às bolsistas a vivência em sala de aula, para conhecer e reconhecer a realidade das escolas públicas, os diferentes perfis e tempos de aprendizagens dos estudantes, bem como as estratégias para suprir eventuais dificuldades. Essa interação serve de base para a formação da identidade docente, pois favorece a formação profissional e pessoal, ao colocar os acadêmicos em contato direto com a dúvidas e necessidades dos alunos.

\section{Considerações finais}

A possibilidade de construir e reconstruir conhecimentos, através da prática laboratorial, teve grande importância para todos os envolvidos. Aos estudantes participantes, além da observação direta de evidências e do manuseio de materiais de laboratório, foi oportunizado visualizar a teoria na prática, de forma a discutir e entender como esses processos se relacionam com as situações cotidianas, além de testar hipóteses, planejar e executar experimentos, desenvolvendo com isso habilidades de investigação científica. Para as bolsistas foi um momento ímpar, de grande aprendizagem e construção do seu perfil docente, possibilitando entender as diferenças presentes em sala de aula e as melhores alternativas para trabalhar com essa diversidade, de forma a atingir os objetivos planejados. 


\section{Agradecimentos}

Agradecemos o apoio da equipe diretiva da escola parceira, o apoio, às bolsistas Luana Boeira e Tatiane Eitelven, que atuaram ativamente em todo o processo de revitalização e aos demais bolsistas Igor P. Pozzebon, Willian Lando, Aline de Godoy, Kétini Baccin, Tayná Trentin e Thaísa Dal Pizzol, que também ministraram aulas práticas.

\section{Referências}

ANDRADE, M. Z. Segurança em laboratórios químicos e tecnológicos. Caxias do Sul: Educs, 2008.

BARCELLOS, V. Por uma ecologia da aprendizagem: o amor como princípio epistemológico em Humberto Maturana. Porto Alegre, RS, 2006.

BRASIL. Parâmetros curriculares nacionais: Ensino Médio. Brasília: MEC, 2000.

CAPELETTO, A. Biologia e educação ambiental: roteiros de trabalho. São Paulo: Ática, 1992.

DEMO, P. Educar pela pesquisa. 7. ed. Campinas: Autores Associados, 2011.

FRANTZ, A. M. F.; CZEIKOSKI, W. L.; CUNHA, G. F. Projetos LABCI e PIBID aproximam universidade e escola, formando professores. In: ENCONTRO REGIONAL SUL DE ENSINO DE BIOLOGIA, 7., 2015, Criciúma. Anais... Erebio, 2015, p. 275-284.

FREIRE, P. Pedagogia da autonomia. Rio de Janeiro: Paz e Terra, 1997.

FREIRE, P.; FAUNDEZ, A. Por uma pedagogia da pergunta. Rio de Janeiro: Paz e Terra, 1985.

GASPAR, A. Experiências de ciências para o Ensino Fundamental. São Paulo: Ática, 2009.

LABURÚ, C. E.; BARROS, M. A.; KANBACH, B. G. A relação com o saber profissional do professor de física e o fracasso da implementação de atividades experimentais no Ensino Médio. Investigações em Ensino de Ciências, Porto Alegre, v.12, n. 3, p. 305-320, 2007.

MORAES, M.C. Pensamento eco-sistêmico: educação, aprendizagem e cidadania no século XXI. Petrópolis: Vozes, 2004.

SILVA, M. I. et al. Estudando a morfologia externa dos insetos nas aulas práticas de laboratório de Zoologia II. V Encontro de Ensino Pesquisa e Extensão da Faculdade SENAC, outubro de 2011. 
THIOLLENT, M. Metodologia da pesquisa-ação. São Paulo: Cortez, 1985.

UNESCO. A reforma curricular e a organização do ensino médio. 2000.

VON LINSINGEN, L. Ciências biológicas e os PCNs. Centro Universitário Leonardo da Vinci - Indaial, Grupo UNIASSELVI, 2010. UNESCO. A reforma curricular e a organização do ensino médio. 2000.

VON LINSINGEN, L. Ciências biológicas e os PCNs. Centro Universitário Leonardo da Vinci - Indaial, Grupo Uniasselvi, 2010. 


\title{
Interdisciplinar (História e Sociologia), Filosofia e História
}

\author{
9
}

NECESSIDADES HUMANAS COMO FUNDAMENTO PARA A EDUCAÇÃO

\author{
Fernanda Dinarowski \\ fdinarowski@ucs.br \\ Subprojeto História \\ EEEM Melvin Jones
}

Resumo: Este artigo é resultado das leituras e reflexões realizadas através do Pibid (subprojeto História), na Universidade de Caxias do Sul. Em linhas gerais, discutimos alguns elementos constitutivos da relação entre educação, classes sociais e políticas públicas sociais, partindo dos conceitos desenvolvidos pela autora Potyara Pereira, Graduada em Serviço Social (1965) e em Direito (1974), Mestra (1973-1976) e Doutora (1982-1987) em Sociologia pela Universidade de Brasília e Pós-Doutora em Política Social pela Universidade de Manchester (1991-1992). O tema das políticas públicas sociais está no centro da relação/conflito entre o Estado e a sociedade. A escola atua diretamente como um aparelho de controle, como pensa Althusser, e o sucateamento da educação pública é um interesse da classe dominante. Procuramos neste sentido contribuir com o debate acerca da temática em tela.

Palavras-chave: Educação. Classes sociais. Alienação. Ideologia. Proteção social. Necessidades básicas.

\section{Políticas sociais a serviço do capitalismo}

As políticas sociais são fruto de um determinado período histórico. Elas surgem a partir de 1914 e generalizam-se como consequência ou "reparo" da Segunda Guerra Mundial até fins de 1960. Portanto ela emerge em uma fase do desenvolvimento capitalista, conhecida como o Imperialismo Clássico. Com a crise de 1929 e por consequência a inflexão da burguesia quanto à confiança no mercado, surgem alternativas para a crise, através de maior intervenção do Estado na economia e nas políticas públicas (New Deal). Nesses casos, a política social também configura uma estratégia anticíclica frente às crises do capital, para regular o processo de reprodução das forças de trabalho. Os sistemas de seguros da previdência, que têm como objetivo garantir renda aos trabalhadores, também funcionam como um meio de não causar um impacto direto e instantâneo na economia, em períodos de recesso, que poderiam ser agravados pela baixa direta do consumo, dentro do quadro econômico.

\footnotetext{
* Coordenadora do subprojeto: Profa. Me. Eliane Machado Corrêa Cardoso; supervisora: Profa. Fabrícia Clave.
} 
Para Eduardo Mourão Vasconcelos, o enfoque da política social, sob a perspectiva politicista, tende a defini-la "como forma de regulação do conflito capital-trabalho e demais conflitos sociais [...], ótica da busca de legitimação e consenso, como resposta à pressão dos movimentos sociais, principalmente dos trabalhadores e/ou como forma de controle político. (1988:6)". (BEHRING, 1998, p. 21).

Com a estagnação econômica, no fim da década de 1960, a burguesia passa a exercer ostensiva pressão para uma supercapitalização, através da mercantilização de mais e mais setores da vida social. O desenvolvimento da microeletrônica, na década de 1980 e o novo modelo de produção toyotista, somado ao advento da globalização foi o meio alcançado para a ampliação da mais-valia no contexto neoliberal (BEHRING, 2008). Para o capital, a regulação do Estado só faz sentido se colabora com a manutenção dos lucros; com a estabilização do mercado a burguesia pressiona o Estado para o congelamento dos investimentos com as políticas públicas sociais.

\section{Necessidades humanas como fundamento para a educação}

Com base na definição feita por Pereira (2000), as necessidades básicas são aquelas que, em todos os tempos, lugares e culturas, são comuns aos seres humanos e fundamentais para o desenvolvimento de uma vida digna. O não acesso ao básico implica sérios prejuízos à vida material dos indivíduos e a atuação dos mesmos como sujeitos informados e críticos, os impactos são negativos e colocam em risco a capacidade física e social de viver. Quando não nos alimentamos adequadamente, não absorvemos diversos nutrientes necessários para o funcionamento adequado do nosso corpo e por efeito adoecemos ou prejudicamos nossa qualidade de vinda. Também temos consciência dos problemas que a falta de saneamento causa à população. Para os autores, existem dois conjuntos de necessidades básicas: as que dizem respeito à saúde e as que se referem à autonomia. A saúde é uma necessidade básica, uma vez que sem saúde ficamos impedidos de viver e, para que tenhamos saúde, precisamos ter garantidas algumas condições mínimas, como alimentação adequada, moradia satisfatoriamente segura, a fim de proteger contra chuvas, tempestades ou frio e calor intensos, como também contra a violência social e urbana. A autonomia é a capacidade que cada indivíduo deve ter de se 
autodeterminar, segundo uma legislação estabelecida; é a aptidão e competência das quais necessitamos para poder gerir a vida, através de nossos próprios meios, vontades e princípios. Essas aptidões e competências podem ser adquiridas por meio de uma educação funcional, com qualidade e para a vida; do acesso aos direitos e de participação social. "A habilidade cognitiva para participar socialmente inclui a compreensão das pessoas acerca das regras de sua cultura e a sua capacidade de raciocinar sobre essas regras e interpretá-las. Isso requer tanto habilidades culturalmente específicas quanto universais". (PEREIRA 2000, p. 71).

A compreensão acerca das necessidades humanas básicas nos ajuda a tentar compreender o sentido da proteção social e dos direitos sociais. No Brasil, essa proteção está garantida pela Constituição brasileira de 1988, que foi escrita com a participação democrática, para garantir os direitos da população, como podemos observar no art. 60:

São direitos sociais a educação, a saúde, a alimentação, o trabalho, a moradia, o transporte, o lazer, a segurança, a previdência social, a proteção à maternidade e à infância, a assistência aos desamparados, na forma desta Constituição.

A educação é o instrumento-chave para a descoberta dos saberes essenciais e fundamentais para a autonomia. Através da educação, as pessoas deveriam aprender como cuidar de si e da própria saúde, como alimentar-se adequadamente, escolhendo os alimentos adequados para suprir os nutrientes necessários para a saúde do corpo. Quando o professor planeja suas aulas, ele deve estabelecer quais são os objetivos e as habilidades que ele deseja desenvolver nos estudantes. De acordo com a Lei de Diretrizes e Bases, a educação tem por princípio e finalidade o pleno desenvolvimento do educando, seu preparo para o exercício da cidadania e sua qualificação para o trabalho, isso porque na sociedade capitalista é através da venda do trabalho que garantimos as condições financeiras para gerir a vida. Apesar disso, a proteção social brasileira não inclui no texto a educação e prevê apenas saúde, previdência e assistência social. A educação não é entendida como fundamental para a proteção social, por consequência do processo histórico-brasileiro de desenvolvimento das políticas públicas sociais, que no Brasil só teve início nos 
anos 1930, como um reflexo para atender à pressão dos movimentos sociais que começavam a surgir com a formação da classe operária. Entretanto, os movimentos sociais foram contidos por governos ditatoriais estabelecidos através de golpes, do Estado Novo (1937-1945) e da Ditadura Militar (19641985). A Constituição brasileira, promulgada somente no final da década de 1980, ocorre quando o capitalismo mundial encontra-se em uma nova fase, o neoliberalismo econômico. Mal estabeleciam-se os direitos dos cidadãos e já dava-se início ao processo de "Contrarreforma", descrito por Behring (2008). A contrarreforma é a resposta da burguesia frente à estagnação da economia. Situação que tem início com o fim da década de 1960 e a formação dos fenômenos que causaram a crise dos anos 1970.

$\mathrm{Na}$ Europa Ocidental, a proteção social constituiu-se, após a Segunda Guerra Mundial, quando o mundo tomou conhecimento das atrocidades da guerra, tornou-se publicamente necessário garantir o bem-estar social assegurando direitos. As organizações políticas passaram a colocar o Estado como agente regulamentador do bem-estar social, ampliando seu papel em relação às políticas públicas. Com a baixa dos lucros nos anos 1970, a burguesia reagiu alterando os modos e meios de produção, numa tentativa de ampliar a mais-valia, pressionando o Estado, para investir mais na economia e menos no social. O forte crescimento tecnológico da década de 1980, através da microeletrônica, criou a possibilidade de automatizar a produção em pequena escala, aumentando a alienação do trabalhador em relação ao trabalho por ele desenvolvido. Esse processo mantêm-se em curso com as novas tecnologias e as novas formas de flexibilização de trabalho, através da descentralização baseada na terceirização e subcontratação em redes de pequenas e médias empresas. As pequenas empresas, às vezes praticamente artesanais, sobrevivem de acordo com a demanda das empresas maiores. A contrarreforma é a resposta do Estado cedendo ao poder econômico, precarizando as políticas de proteção e segurança dos trabalhadores, flexibilizando as relações contratuais entre patrões e empregados, em favor do empresariado e suprimindo seu papel nessas relações, principalmente no que diz respeito à proteção social. Atualmente está em curso no Brasil a contrarreforma da Previdência e, no ano passado, ocorreu o congelamento das verbas destinadas ao financiamento de políticas sociais, como saúde e educação. A contrarreforma é um processo que faz parte do 
neoliberalismo econômico e tem como características principais: a crítica ao Estado de Bem-Estar Social e as práticas sociais-democratas, bem como a redução da intervenção do Estado na economia, cabendo a este apenas o papel de fiscalizador, não promotor. (BRUM, 1998, p. 27).

Os problemas enfrentados pela educação são históricos. O Brasil como país periférico e dependente em relação ao capitalismo mundial, modelo adotado historicamente, pouco conseguiu alterar no modelo tradicional voltado para o trabalho e não para a autonomia em relação à vida e à saúde. A superestrutura não nos permite alterar esse modelo. A formação dos professores, os problemas de gestão, a falta de estrutura interna ou o não comprometimento dos alunos são fatores que estão diretamente ligados à forma como a política de educação é feita no Brasil. Situação que se agrava com a "concorrência" das redes privadas, que permite às Classes Médias e Altas garantirem educação com maior qualidade para seus filhos.

Como podemos perceber, as políticas sociais não dialogam, falamos em educação sem garantir saúde e assistência, em um momento em que a fome volta a crescer, assim como os problemas relacionados às condições sociais de moradia. O Estado brasileiro não é capaz de garantir as necessidades básicas da população, tornando inviável o alcance de uma sociedade mais justa e igualitária e quando passa a entregar as políticas públicas nas mãos do capital financeiro, através das privatizações, as possibilidades ficam ainda menores, porque ao capital não importa o desenvolvimento humano, o que interessa são os lucros, que só podem ser ampliados, através da exploração e reprodução da classe trabalhadora.

\section{Educação no Brasil no século XX}

A educação no Brasil sempre foi um privilégio de quem possuísse as condições financeiras para acessá-la e até mesmo com os processos de independência e substituição de mão de obra escrava pela mão de obra assalariada, durante o século XIX, continuou sendo um privilégio de poucos. Com a industrialização a partir da década de 1930 e a necessidade de alguns saberes técnicos e básicos para as condições de trabalho dentro das fábricas, a educação pública não teve como objetivo empreender um currículo visando à autonomia, 
mas a satisfação do capital e a formação de operários. O fato de a educação privada sempre existir no Brasil e a falta de coragem para bani-la, após a Constituição e de privilegiá-la com uma política social fundamental e de responsabilidade única do Estado, tornando-a igual e justa para todos, nos faz pagar alto preço nos dias atuais, tamanha é a dificuldade dos professores diante de um acúmulo na estagnação da educação e sua desvalorização como política pública.

Com a queda da monarquia em 1889, e a Constituição de 1891 é instaurado o governo representativo, federal e presidencial. No campo político, prevaleceu a influência dos coronéis, dos fazendeiros de café e criadores de gado. Após a Primeira Guerra Mundial, começa a lenta mudança do modelo agroexportador, o surgimento de uma elite burguesa industrial e um operariado urbano. A década de 1920 foi extremamente fértil em relação aos movimentos sociais: greves, tenentismo, coluna Prestes, Semana de Arte Moderna, Partido Comunistas, etc. Como resultado a todos esses movimentos ocorre a Revolução de 30, quando Getúlio Vargas aproveita a situação e torna-se chefe do governo provisório. Com o golpe de 1937 e a ditadura do Estado Novo, a opinião pública passa a ser manipulada pela propaganda do governo e pela censura (DIP), enquanto a oposição é sufocada com prisões, tortura e exílio. No final de 1920, o analfabetismo atingia $80 \%$ da população brasileira e tornava-se necessário mudar os rumos da educação. A indústria se desenvolvia e exigia a capacitação dos trabalhadores para o plano de desenvolvimento nacionalista da Era Vargas. Em 1932, é realizado o Manifesto dos Pioneiros da Educação, uma proposta de renovação das escolas e da educação brasileira, escrito por vinte e três homens e três mulheres, educadores e intelectuais de renome, entre eles: Fernando de Azevedo, Lourenço Filho e Anísio Teixeira. Propunham uma grande reforma para organizar a educação: "É impossível desenvolver as forças econômicas ou de produção sem o preparo intensivo das forças culturais e o desenvolvimento das aptidões à invenção e à iniciativa que são os fatores fundamentais do acréscimo de riqueza de uma sociedade". (Manifesto dos pioneiros da educação, 1932).

O manifesto gerou uma grande disputa entre os pioneiros e os educadores católicos pelo poder de definir o rumo da educação brasileira. A Igreja nesse período travava sua luta contra a ameaça comunista, defendendo os governos ditatoriais e apoiando o governo fascista de Mussolini, através da assinatura do 
Pacto Lateranense. A Igreja entendia as ditaduras como positivas, uma vez que os governos liberais ou socialistas desconsideravam a influência da Igreja e defendiam um estado laico, situação muito bem-explicada pela historiadora caxiense Loraine Slomp Giron, em seu livro: As sombras do littorio: o fascismo no Rio Grande do Sul.

Com a adesão da Igreja ao Fascismo, o regime conseguiu prevenir qualquer reação contrária ao poder, bem como passou a dispor da extraordinária máquina da Igreja espalhada pelo mundo, sejam escolas, jornais e revistas, bem como as próprias paróquias, tribuna de audiência obediente e certa das posições da Igreja. (GIRON, 2017, p. 122).

O ministro da Educação e Saúde Pública, Francisco Campos, embora influenciado pelo manifesto, era católico e antiliberal, colaborou para o retorno do Ensino Religioso ao currículo escolar. Além da escola pública, as igrejas dominavam o Ensino Privado, permitido pela Constituição de 1934. A partir de 1945, o Brasil viveu um breve momento de democratização; a nova Constituição passou a responsabilidade da educação para as mãos da União. Em 1948, o ministro Clemente Mariani lançou o projeto para a Lei de Diretrizes e Bases da Educação Nacional, que foi extremamente disputado pela frente escolanovista e a Igreja católica. O longo debate fez com que a lei só fosse aprovada treze anos mais tarde, permitindo a pluralidade dos currículos e estabelecendo que o Estado passasse a destinar os recursos às entidades privadas. Entre os anos de 1950 a 1960, prevaleceu o populismo no Brasil, com o retorno de Getúlio Vargas entre os anos de 1951-1954. Também houve movimentos em favor da educação popular, destacando-se Paulo Freire. O famoso intelectual e educador brasileiro ficou conhecido por alfabetizar 300 trabalhadores rurais em 45 dias na cidade de Angicos, $171 \mathrm{~km}$ de Natal. O período também foi marcado por manifestações culturais, como o Cinema-Novo e a Bossa-Nova.

Em 1964, todas as tentativas foram esmorecidas com o Golpe Militar (1964-1985). Propostas de uma Educação mais democrática foram abandonadas com o início do regime, em 1964. Paulo Freire foi exilado no Chile e a EscolaNova deixou de ser considerada para as políticas públicas. Dermeval Saviani, no livro História das ideias pedagógicas no Brasil, fala sobre o simpósio do Instituto de Pesquisas e Estudos Sociais, em que a meta do evento era a elaboração de um 
plano de Educação com a escola primária voltada para uma atividade prática e o segundo grau técnico que preparasse o estudante para o mercado de trabalho. $\mathrm{Na}$ educação de adultos, as ideias de Freire deram lugar a um modelo assistencialista, por meio do Movimento Brasileiro de Alfabetização (Mobral). De acordo com Maria Lúcia Arruda Aranha, em 1970, 33\% das pessoas com mais de 15 anos eram analfabetas; dois anos depois, a taxa caiu para $28,51 \%$. No entanto, ela ressalta que, por causa do método usada muitos alunos maldesenhavam o nome. A ditadura militar também significou uma repressão política e ideológica no Brasil. Para mudar a ideologia de um país é necessário instrumentos, e a escola é uma grande agência de doutrinação. A censura limitou o acesso à informação. E o regime tornava-se forte com disciplinas de moral e cívica, mistura conservadora reacionária e religiosa, que buscava doutrinar os jovens. A disciplina de Língua Portuguesa, tornou-se Comunicação e Expressão com caráter meramente instrumental. Apesar do recurso do salário educação criado em 1964 e revisto em 1975, pelo qual as empresas pagavam imposto relativo aos filhos de funcionários em idade escolar, os investimentos na área decresceram ao longo do regime. No Estado de São Paulo, por exemplo, de 8,7 salários-mínimos, os professores passaram a receber 5,7 salários, em 1979, segundo o livro Educação, Estado e democracia (Luiz Antônio Cunha, 495 p., Ed. Cortez).

\section{Educação na pós-modernidade}

A escola hoje está muito longe de ser um local onde os jovens desejam estar. Ele não consegue mais ver a finalidade da escola enquanto local onde os conteúdos são transmitidos sem complexidade e sentido para a vida. A função de transmitir os conhecimentos acumulados não cabe mais ao professor, todas as respostas para as perguntas estão disponíveis na internet e, mais do que nunca, o papel da educação é desenvolver as habilidades relacionadas à autonomia. Não é à toa que a evasão escolar tem aumentado muito nos últimos anos, e Caxias do Sul encontra-se acima da média nacional da evasão escolar, que é ainda maior no Ensino Médio. O Ensino Médio é de fundamental importância, é uma fase de maior amadurecimento cognitivo, em que o jovem passa pela fase da adolescência, em que os dilemas e as frustrações em relação ao mundo e a vida 
aumentam. "A tragédia dos adolescentes é que começam a viver um mundo que nega os valores que thes foram ensinados". (MATURANA, 2002, p. 35).

Quando educamos as crianças falamos sobre o amor, ensinamos sobre o amor, o amor entre os pais, entre os irmãos. Essa é uma emoção prazerosa que permite que a criança se sinta segura e confiante, quando falamos em amor e demonstramos amar uma criança não estamos negando sua personalidade, sua criatividade e sua existência. (MATURANA, 2002). Mas quando a tiramos do convívio familiar para que ela tenha seu primeiro contato social, através do convívio escolar, imediatamente passamos a estimular a competição e a negação; estimulamos a vontade de querer ser melhor, de negar o outro em prol de uma afirmação individual e não coletiva; avaliamos individualmente e não coletivamente, ensinamos o individualismo. Nisso não há amor, e o que se constitui é a formação de um espaço relacional conflituoso. Negamos o amor dos ensinamentos iniciais e do seio familiar. Maturana nos explica que a competição não é biológica, ela é humana e cultural. A emoção é prévia e fundamenta a escolha racional, é pela emoção que nossos ancestrais evolutivos desenvolveram o contato e o espaço relacional, permitindo, a partir desse espaço, o desenvolvimento da linguagem e da escrita. (MATURANA, 2002).

A escola como conhecemos está distante da comunidade e não está associada com as outras necessidades vividas por ela. O professor é impedido de tratar sobre aspectos políticos importantes, que deveriam ser de direito ao estudante, como vemos atualmente através de projetos como o Escola sem Partido. O sucateamento da educação pública é uma realidade e a situação piora a cada instante com o congelamento do orçamento; professores que enfrentam dificuldades financeiras recebendo salários parcelados. Para Freire (2011), a formação da classe trabalhadora, na perspectiva progressista pós-moderna e democrática, tem o direito de saber como funciona sua sociedade, de conhecer seus direitos, seus deveres, de conhecer a história da classe operária. Conhecer o papel dos movimentos populares, a história de seu País, as classes sociais, a geografia, a linguagem e a ideologia. A questão econômica torna o papel da educação contraditório, porque o sistema tem em si certas características e certas exigências que, do ponto de vista ético, são extremamente problemáticas, visto que o sistema capitalista vive essencialmente da competitividade. 


\section{Qual o papel da política social?}

A política social integra uma estratégia global anticrise do capital, após 1929. Mas ela não é apenas uma estratégia econômica, ela também é uma resposta política frente aos diversos movimentos sociais que emergem pelo mundo, durante a década de 1920, frente aos inúmeros movimentos de greve por parte das classes operárias, a criação de partidos comunistas principalmente após a consolidação da Revolução Soviética de 1917. A situação da guerra e do fascismo também significou uma derrota para o movimento operário, com o triunfo do capitalismo, somado pelo destino da experiência socialista-soviética, que fragilizou o movimento operário. O conceito de bem-estar social e a ampliação do Estado, nas políticas sociais, foi a resposta dada à classe trabalhadora, maior prejudicada pela situação da guerra. É nos territórios afetados diretamente pelo confronto, que o Estado de bem-estar social vai efetivamente se concretizar. Aqui no Brasil chega somente em 1988, através do art. 194 da Constituição Federal:

Art. 194. A seguridade social compreende um conjunto integrado de ações de iniciativa dos Poderes Públicos e da sociedade, destinadas a assegurar os direitos relativos à saúde, à previdência e à assistência social.

Sem educação não há autonomia na vida e na participação político-social. Um indivíduo que não é autônomo intelectualmente, se não possui proteção social, porque não é capaz de resistir em relação à investida burguesa contra os direitos sociais, que acabam sendo interpretados pela lógica hegemônica do mérito, da competitividade e não do direito. A educação está excluída da proteção social brasileira, porque não interessa ao capital desvincular a classe trabalhadora da dependência com o mercado, com o consumo e com as relações de trabalho estipuladas pelo capitalismo. A educação e o conhecimento são fundamentais na tomada da consciência de classe; somente pela educação aumentaríamos nossa participação na história e na política, enquanto classe trabalhadora e alcançaríamos a autonomia necessária para cuidarmos de nossa vida como indivíduos.

A Declaração de Alma-Ata é um documento formulado por ocasião da Conferência Internacional sobre cuidados primários de saúde, realizada em Alma-Ata, na extinta URSS em 1978, dirigindo-se a todos os povos do mundo. Composta de 10 itens que enfatizam a atenção primária à saúde, salientando a 
necessidade especial de atenção nos países em desenvolvimento. $O$ documento tem sido considerado como a primeira declaração internacional, que despertou a importância da atenção primária em saúde e é defendida pela OMS como a chave para a promoção de saúde de caráter universal. Encontramos em seus 10 itens vários aspectos diretamente relacionados à educação como estratégia importante para a autoconfiança, automedicação, educação para problemas prevalecentes de saúde e para os métodos de prevenção.

\section{Referências}

ARANHA, Maria Lúcia de Arruda. História da educação. 2. ed. rev. e atual. São Paulo: Moderna, 1996.

BEHRING, Elaine Rossetti. Política social no capitalismo tardio. São Paulo: Cortez, 1998.

BRUM, Argemiro Jacob. $O$ desenvolvimento econômico brasileiro. 14. ed. Petrópolis, RJ: Vozes, 1995.

FREIRE, Paulo. Pedagogia da autonomia: saberes necessários à prática educativa. 55. ed. São Paulo: Paz e Terra, 2017.

GIRON, Loraine Slomp. As sombras do littório: o fascismo no Rio Grande do Sul. 2. ed. Caxias do Sul: Educs, 2017.

MATURANA, Humberto. Emoções e linguagem na educação e na política. Belo Horizonte: UFMG, 2002.

NOAL, F. Evasão escolar no Ensino Médio de Caxias aumenta quatro vezes em 20 anos. Pioneiro, 2017. Disponível em: <www.pioneiro.clicrbs.com.br/rs/geral/noticia/2017/02/evasao-escolar-no-ensinomedio-de-caxias-aumenta-quatro-vezes-em-20-anos-9717195.html>. Acesso em: 10 fev. 2017.

PEREIRA, Potyara A. P. Necessidades humanas: subsídios à crítica dos mínimos sociais. 2. ed. São Paulo: Cortez, 2002.

PEREIRA, Potyara A. P. Política social: temas e questões. 3. ed. São Paulo: Cortez, 2011. RODRIGUES, Marly. O Brasil na década de 1920: os anos que mudaram tudo. São Paulo: Ática, 1997. 


\title{
O CONCEITO COMO METODOLOGIA NAS PRÁTICAS DO PIBID/UCS-FILOSOFIA
}

\author{
Patric de Oliveira Peres \\ poperes@ucs.br \\ Subprojeto: Filosofia \\ Escola Estadual de Ensino Médio São Caetano
}

\begin{abstract}
Resumo: O presente trabalho discorre sobre a compreensão a respeito do que seja um conceito para Deleuze e Guattari e este como sendo um aporte a uma metodologia que vise ao filosofar. Para isto, faz-se a análise do capítulo "O conceito" na obra O que é filosofia?, dos mesmos autores. A fim de se explorar mais diretamente o alcance de tal concepção para o ensino da filosofia, avança-se por alguns estudos de Sílvio Gallo e Renata Aspis, que se voltam aos aspectos metodológicos. Em seguida, são apresentadas as bases teóricas propostas pelos documentos que regulam o ensino e como as metodologias fundamentadas nos conceitos se enquadram nelas. Por fim é apresentada a metodologia que balizava as atividades do Pibid/UCS-Filosofia para a estruturação das oficinas realizadas na Escola São Caetano, ao longo dos quatro primeiros anos do projeto. E encerra explanando sobre as mudanças que ocorriam na estrutura dos planejamentos, de acordo com os objetivos finais das atividades.
\end{abstract}

Palavras-chave: Conceito. Deleuze e Guattari. Metodologia. Filosofar.

\section{Introdução}

O presente trabalho parte de uma pesquisa bibliográfica em metodologias de ensino de filosofia e de suas bases teóricas, pois procura explorar os elementos que fundam as metodologias para a filosofia de cunho pós-crítica e relatar como eles permitem uma metodologia mais ativa do ensino de filosofia. Para isto, o texto discorre sobre a compreensão a respeito do que seja um conceito em Deleuze e Guattari. Assim, faz-se a análise do capítulo "O conceito" na obra $O$ que é filosofia?, dos mesmos autores. Após, como essa teoria serve de aporte a uma metodologia que visa ao filosofar e não apenas um saber histórico de filosofia. Busca-se, em alguns estudos metodológicos que se voltam a aspectos teóricos fundamentados na teoria do conceito francesa, o alcance do conceito nas suas propostas didáticas.

\footnotetext{
${ }^{*}$ Graduado no curso de Licenciatura em Filosofia na Universidade de Caxias do Sul (UCS). E-mail: poperes@ucs.br Coordenador: Prof. Dr. Luís Fernando Biasoli. E-mail: luisbiasoli@hotmail.com Supervisora: Profa. Me. Tenisa Zanoto Boeira.E-mail: tenisa.boeira@gmail.com
} 
As metodologias são investigadas em nível bibliográfico e suas aplicações, feitas no início do Programa Institucional de Bolsa de Iniciação à Docência, no subprojeto de Filosofia, na Universidade de Caxias do Sul (Pibid/UCS), são relatadas no que tange às suas estruturas e algumas de suas consequências em sala de aula. Cabe ressaltar a validade das propostas metodológicas, apontando os documentos que regulam os parâmetros político-educacionais nas escolas.

A análise é válida para aqueles que buscam uma metodologia ativa em sala de aula, na qual o papel do aluno não seja o de apenas armazenar informações, mas, sim, o de criar e recriar a partir do conceito como ferramenta. Buscam-se aproximações e divergências entre a teoria do conceito proposto pelos filósofos franceses e o das metodologias propostas por Aspis (2004) e por Gallo (2006), possibilitando maior percepção de mais aspectos que envolvem esta base metodológica e sua possibilidade de variações para determinadas práticas pedagógicas.

O texto segue expondo as considerações do grupo do Pibid/UCS-Filosofia sobre as etapas da proposta de Gallo (2006) e, posteriormente, como elas foram modificadas, dependendo dos objetivos das diversas propostas ao longo dos quatro anos do projeto de Pibid. (2014 até 2018).

\section{O conceito}

A compreensão de conceito que é trabalhado, aqui, tem como base teórica Deleuze e Guattari (1997). Por ser a teoria do conceito, a base das metodologias ativas a serem apresentadas, posteriormente, neste capítulo é abordado o conceito, na proposta dos franceses Deleuze e Guattari (1997). Para os filósofos, o conceito surge como uma necessidade e não como uma simples vontade de criação. Para Deleuze a filosofia é

[...] uma disciplina tão criativa, tão inventiva quanto qualquer outra disciplina, e ela consiste em criar ou inventar conceitos. E os conceitos não existem prontos e acabados numa espécie de céu em que aguardariam que uma filosofia os apanhasse. Os conceitos, é preciso fabricá-los. É claro que os conceitos não se fabricam assim, num piscar de olhos. (1987, p. 3).

O conceito é a criação exclusiva da filosofia. "Mas, mesmo na filosofia, não se cria conceitos, a não ser em função dos problemas que consideram mal vistos 
ou mal colocados (pedagogia do conceito)". (Deleuze; Guattarl, 1997, p. 28). Assim percebemos que o "novo" conceito precisa sempre estar vinculado a uma "nova" demanda.

Todo o conceito precisa de outros conceitos, para se sustentar. Há, também, a característica de devir em cada conceito, e esta característica possibilita-lhe ser usado para dar suporte a mais de um problema.

Deleuze e Guattari (1997) apontam, na obra O que é filosofia? elementos para a construção conceitual. Não definindo esses elementos como etapas, mas como partes constituintes, sendo estes: personagem, campo de imanência e conceito. Em primeiro lugar, os conceitos não saem do nada, pois eles sempre são construções de outros conceitos. Eles possuem um lugar e quem os pense, um personagem. Em segundo lugar, a consistência do conceito depende do fazer de seus componentes inseparáveis nele; assim eles são distintos, heterogêneos e não separáveis. Ou seja, eles precisam estar dispostos a mais conceitos, como uma rede abstrata onde se cruzam os conceitos, o campo de imanência. "Em terceiro lugar, cada conceito será, pois, considerado como o ponto de coincidência, de condensação ou de acumulação de seus próprios componentes". (Deleuze; GuATTARI, 1997, p. 32). Sendo assim, é o conceito em si.

Este terceiro ponto pode ser a característica que viabiliza o plano de imanência, local abstrato onde os filósofos fazem interação entre os conceitos construídos.

O conceito diz o acontecimento, não a essência ou a coisa. É um Acontecimento puro, uma hecceidade, uma entidade: [...]. O conceito define-se pela inseparabilidade de um número finito de componentes heterogêneos percorridos por um ponto em sobrevôo absoluto, à velocidade infinita. Os conceitos são "superfícies ou volumes absolutos", formas que não têm outro objeto senão a inseparabilidade de variações distintas. 0 "sobrevôo" é o estado do conceito ou sua infinitude própria, embora sejam os infinitos maiores ou menores segundo a cifra dos componentes, dos limites e das pontes. $\mathrm{O}$ conceito é bem ato de pensamento neste sentido, o pensamento operando em velocidade infinita (embora maior ou menor). (Deleuze; Guattari, 1997, p. 33).

Ao trabalharmos esta perspectiva de conceito, saímos de uma metodologia que não se confina à história da filosofia. Sua capacidade de unicidade, por ser um acontecimento, permite passarmos a "produzir filosofia a partir da história 
da filosofia, mas não ficando confinado a ela, apenas reproduzindo o pensamento, mas criando novos conceitos. A história da filosofia é a base da qual se parte, não mais o ponto de chegada". (GALLO, 2007, p. 14-15).

Gallo comenta a metodologia dos filósofos franceses:

Para eles, a criação de conceitos é, necessariamente, uma intervenção no mundo, ela é a própria criação de um mundo. Assim, criar conceitos é uma forma de transformar o mundo; os conceitos são as ferramentas que permitem ao filósofo criar um mundo à sua maneira. Por outro lado, os conceitos podem ainda ser armas para a ação de outros, filósofos ou não, que dispõem deles para fazer a crítica de mundo, para instaurar outros mundos. (GALLO, 2007, p. 22).

Temos, então, uma ferramenta que dá suporte a uma perspectiva da realidade e permite modificar a realidade de seu criador. Ao ser aplicada esta proposta metodológica que vise um ensino de filosofia ativa na educação, pode ser pretendida não por formar filósofos puros, mas alunos com senso crítico e capazes de interpretar e estruturar aquilo que pensam.

Assim, o conceito não deve ser procurado, pois não está aí para ser encontrado. O conceito não é uma "entidade metafísica", ou um "operador lógico", ou uma "representação mental". O conceito é um dispositivo, uma ferramenta, algo que é inventado, criado, produzido, a partir das condições dadas e que opera no âmbito mesmo destas condições. O conceito é um dispositivo que faz pensar, que permite, de novo, pensar. O que significa dizer que o conceito não indica, não aponta uma suposta verdade, o que paralisaria o pensamento; ao contrário, o conceito é justamente aquilo que nos põe a pensar. Se o conceito é produto, ele é também produtor: produtor de novos pensamentos, produtor de novos conceitos; e, sobretudo, produtor de acontecimentos, na medida em que é o conceito que recorta o acontecimento, que o torna possível. (GALLO, 2007, p. 28).

Desta capacidade de fazer pensar, a construção conceitual possibilita ao estudante compreender-se como ser que se pensa. Suas construções podem, em uma primeira instância, dar-se como uma abordagem que representa como ele encara a realidade. A partir do momento em que ele percebe que o outro pensa (e vê) outra perspectiva, às vezes, mais ou menos interessante que a sua e que os dois partem de diferentes fundamentações, abre-se aí uma gama de diversos assuntos dentro da filosofia, que podem ser trabalhados na sala de aula, seja em aula ou em oficina. 


\section{Análise das metodologias que usam o conceito como aporte}

Neste capítulo, são apresentadas a base curricular do Estado do Rio Grande do Sul, duas propostas metodológicas, a saber, Gallo (2006) e Aspis (2004) e a relação entre ambas. Aí, a análise da base curricular é cabível, devido a questões de ordens burocrática e políticas. Nas propostas metodológicas, a ideia do conceito é tida como aporte para um ensino de filosofia de modo ativo. Tem-se deste modo a relação entre o que é proposto como base teórica pelo Estado, para que seja referência em sala de aula e o que essas metodologias pós-críticas, embasadas nos franceses, podem vir a auxiliar na tarefa docente do professor de filosofia.

Vale ressaltar que há metodologias que visam à construção de conceitos. Podem ser citadas, aqui, ideias construídas por Gallo (2006) e Aspis (2004). As reflexões destes filósofos brasileiros, seus desdobramentos metodológicos e suas implicações curriculares, de forte inspiração em Deleuze e Guattari (1997), mostram-se muito condizentes com as propostas pedagógicas pós-modernas. Estruturas com este formato de prática pedagógica são analisadas como pósmodernas, pois flexibilizam a metodologia tradicional e moderna, estabelecemse como críticas das metodologias e abrem maior espaço para a autonomia dos alunos.

Como as práticas metodológicas nas salas de aula precisam estar de acordo com as propostas políticas impostas pelos órgãos governamentais que regulam a educação, é necessária uma leitura dos documentos que regulam as propostas político-pedagógicas das instituições de ensino brasileiras. Pode-se notar uma forte recomendação de estruturas pedagógicas freireanas (modernas ou também chamadas de críticas) pelo governo do Rio Grande do Sul, no ano de 2011. Isto é possível ser analisado no documento Proposta pedagógica para o ensino médio politécnico e educação profissional integrada ao ensino médio 2011-2014.

Nestas propostas curriculares, há ideias como de autonomia, diferenças, democracia do saber e politização do aluno. Entretanto, o discurso pós-moderno (também chamado de pós-crítico) difere, pois os retoma, amplia e modifica o 
meio, para chegar ao objetivo que é a educação e o ensino. Faz críticas aos paradigmas e, assim, indaga o objetivo das práticas.

Já no documento de 2016 intitulado Reestruturação curricular ensino fundamental e médio - 2016, lançado pela Secretaria de Estado da Educação do Rio Grande do Sul (Sedu-RS), os pilares são:

\section{$[\ldots]$ aprender a conhecer, aprender a fazer, aprender a conviver e aprender a ser. Ou seja, o processo de ensino e de aprendizagem voltado apenas para a absorção de conhecimento e que tem sido objeto de preocupação constante de quem ensina e aprende, deverá dar lugar ao ensinar a pensar, saber comunicar-se e pesquisar, ter raciocínio lógico, fazer sínteses e elaborações teóricas, ser independente e autônomo. (SEDU-RS, 2016, p. 8).}

Sua proposta está mais alinhada a uma estrutura pós-moderna, pois o foco não é apontar o meio e o fim no conteúdo, "[...] trabalha sem o compromisso de perpetuar certezas, mas com um compromisso ético-político". (MATOS, 2009, p. 130). Além disso, não apresenta uma didática fixa, permitindo uma criação de propostas educacionais para dar conta do ensino.

Nas abordagens metodológicas e curriculares de Aspis (2004) e Gallo (2006), existe uma estrutura que pode ser simplificada por uma sensibilização, problematização, investigação e construção conceitual. Dentre as metodologias aqui tratadas, pode-se notar que não divergem muito.

A sensibilização é um momento que ocupa espaço no planejamento, em primeiro lugar, para as reflexões metodológicas de Gallo (2006). É o momento em que o aluno, através de uma música, de um vídeo, ou tela toma um aspecto da obra (a ser trabalhado pelo professor) como um ponto de partida. O uso da arte nesta etapa é apenas introdutório para o tema.

No segundo momento - a problematização -, é referido o tema que se torna o problema a ser trabalhado, mas também é onde a obra que sensibilizou o aluno funciona como pano de fundo para o restante do processo, que visa ao filosofar. O filosofar, aqui referido, é a criação de conceito. A sensibilização é o momento em que o aluno compreende o tema e começa a sentir o problema, a fazer do problema proposto o "seu problema".

Após isto no terceiro momento, a investigação é sobre o quê? O aluno se volta para a tradição da filosofia, para buscar conceitos que tratem daquele 
problema. Assim, o aluno realiza uma pesquisa de como o problema havia sido tratado e respondido por alguns filósofos, durante os mais de 2500 anos de filosofia.

No quarto e último momento, conceituação, há a recriação e/ou criação de conceitos que visam a tentar equacionar o problema já estabelecido.

Nessa reflexão sobre uma metodologia, Gallo (2006) prima pela qualidade da experiência, do processo de filosofar, não do produto final (o conceito). Na segunda metodologia, a de Aspis (2004), há uma problematização, em que a sensibilização está subordinada ao problema que é posto pelos alunos (o problema vem de uma leitura de mundo). Nessa metodologia, é necessário um professor/filósofo que monte conceitos, faça pesquisas e pense filosoficamente. Da problematização, o caminho é muito semelhante à metodologia proposta por Gallo (2006); há uma pesquisa na tradição e após uma construção conceitual que equacione o problema. Há uma prioridade na construção conceitual, assim como na proposta de Gallo (2006), que prioriza uma estrutura racional, em que se visa a chegar a um produto, o conceito.

\section{Análise do uso da metodologia}

Nas práticas do Pibid/UCS-Filosofia, as metodologias de ensino ativo de filosofia, principalmente a de Gallo (2006), serviram de base para grande parte das atividades, em geral oficinas aplicadas aos alunos de Ensino Médio da Escola São Caetano. A escola foi a parceira, onde as atividades do programa aconteciam.

As propostas apresentadas nas atividades do Pibid/UCS-Filosofia tinham raiz pós-modernas e se adequavam às propostas da Escola São Caetano, que tinha,como sua base curricular, o documento apresentado pelo Sedu (2016) acima mencionado.

As oficinas foram desenvolvidas levando em conta os quatro momentos propostos na metodologia de Gallo (2006), a saber: sensibilização, problematização, investigação e construção conceitual.

A sensibilização, nas atividades, era o primeiro momento. Nela era apresentado aos alunos algum vídeo, texto e ou música que abordava o problema ou tema a ser trabalhado. Havia sempre uma preocupação com o 
material selecionado, se ele dava conta do objetivo, se a linguagem era acessível, se a duração era apropriada, se o local dispunha dos meios para apresentar (datashow, rádio, espaço), etc. Cabia nesse momento uma busca de aproximar o problema filosófico à realidade do aluno, transpor o problema para a realidade do aluno.

Na problematização, o problema era apresentado de fato. Nessa etapa, onde os alunos começavam a colaborar na atividade de forma mais decisiva. Eles colocavam suas respectivas bagagens no que fora visto na sensibilização e apresentavam suas percepções. Dessas percepções, era incumbido ao bolsista explorar, problematizar cada avanço, contrapor uma perspectiva à outra. 0 objetivo nesta etapa era apresentar o problema como ele de fato era, complexo e instigante.

$\mathrm{Na}$ investigação havia uma retomada na história da filosofia e o bolsista apresentava uma ou mais teorias que buscavam responder ao problema. A medida que as atividades iam sendo desenvolvidas, o grupo observava que ao menos duas teorias sobre o mesmo ponto tornavam os debates mais interessantes aos alunos, pois, uma vez apresentada uma teoria, tendiam a se apoiar teoricamente no que fora apresentado, não se permitindo formular um novo conceito, apenas apropriar-se dele.

A construção conceitual era o momento final da atividade. Nela, a participação dos alunos variava conforme se desenvolviam as etapas anteriores. Era o segundo momento em que o protagonismo era atrelado aos alunos. Nessa etapa, não se buscava uma fixação do que fora investigado nas teorias filosóficas. A ideia era de uma ampliação da percepção da problemática e de uma construção própria de conceitos, que pudessem tratar do que fora apresentado e debatido.

Levando em conta o objetivo da atividade, os momentos precisavam ser redimensionados, para melhor atender à demanda. Dividindo-as em quatro permite melhor análise de cada momento que precisava ser ampliado.

Quando se tratava de uma perspectiva de mundo, a sensibilização era o cerne da atividade. Pode-se dizer que, desta categoria, surgiram e se estruturaram as oficinas que vinculavam a literatura com a filosofia. Como nessas atividades a confecção das oficinas explorava o que há de filosófico na literatura, era papel dos bolsistas encontrarem em alguma obra literária o que 
mais os sensibilizasse, para percorrerem o caminho do processo de filosofar e construírem as oficinas. O primeiro momento era o central da atividade e tornava necessária a retomada durante os outros momentos, para uma apresentação mais proveitosa do objeto principal da atividade.

Um problema filosófico, quando ganhava destaque, deixava toda a oficina em torno do problema. A sensibilização apresentava o problema, mas a investigação geralmente tinha como objeto o aluno e poucas vezes os filósofos. Não se buscava uma resposta que agradasse a todos, mas sim debates. E esses conduziam as atividades cujo o foco era o problema filosófico. Assim, as oficinas que tratavam de bioética, aqui, ganhavam melhor desenvolvimento.

Se a proposta enfatizava uma investigação, então a sensibilização precisava ser condizente com a proposta a ser explorada. Por exemplo, em oficinas em que o foco era trabalhar uma determinada ideia de um filósofo, o primeiro momento precisava estar contextualizado ao filósofo para, desta forma, permitir uma retomada que não abrisse outra investigação. Essas, por vezes, tinham a intenção de ser mais aulas do que oficinas. Suas propostas visavam a um conteúdo, que, quando em um formato mais próximo de oficina, permitia uma exposição participativa e menos cansativa aos alunos.

As oficinas cujo foco era a apropriação de conceitos podem ser consideradas, em geral, as que foram apresentadas nas etapas regionais das olimpíadas de filosofia. Nelas os momentos têm uma estrutura que conduz os alunos a um problema diferente. "Como apresentar tudo o que vimos de uma forma artística e em pouco tempo?" Essas oficinas davam ao aluno a missão de comunicar ao grande grupo quais as suas percepções sobre o que fora discutido. Nessas falas, víamos o quanto era novo aos alunos e o quanto era trazido de suas perspectivas de mundo. Muitas falas nos surpreendiam positivamente, pois nem sempre tudo o que era apresentado ao grande grupo fora debatido em sala.

\section{Conclusões}

Da pesquisa feita sobre os elementos fundantes das metodologias de ensino de filosofia ativa podemos perceber a centralidade no conceito e sua importância para a prática docente, nestas perspectivas. Partindo do conceito como objetivo final, temos uma metodologia na qual a filosofia não é 
conteudista mas autônoma, para se recriar a partir das percepções de mundo dos alunos.

Gallo e Aspis estruturam os elementos constituintes da teoria francesa do conceito e formulam metodologias muito semelhantes. Ambas as metodologias permitem um ensino de filosofia mais ativo e ambas são condizentes com o que é proposto pelos órgãos políticos que regulam o ensino. Pois, enquanto uma proposta cria o problema e o instaura nos alunos (GALLO, 2006), a outra (AsPIS, 2004) faz do problema dos alunos o seu ponto de partida. Dessa divergência, há apenas a manutenção da etapa de sensibilização do aluno. Entre a teoria do conceito proposto pelos filósofos franceses e as propostas metodológicas explanadas se mantém para ambos uma ênfase do conceito como uma ferramenta não alienante.

Nas atividades realizadas pelo Pibid/UCS-Filosofia fora pertinente o uso da metodologia de Gallo. Entretanto, fora percebido ao longo das atividades que, para melhor alcançar os objetivos propostos, para cada oficina, era necessária certa variação das etapas.

\section{Referências}

ASPIS, Renata Pereira Lima. O professor de filosofia: o ensino de filosofia no ensino médio como experiência filosófica. Cadernos cedes, Campinas, v. 24, n. 64, p. 305-320, 2004.

DELEUZE, Gilles. $O$ ato de criação. 1987. In: Folha de São Paulo, 27/6/1999. Disponível em: <http://www.filoczar.com.br/filosoficos/Deleuze/Gilles Deleuze - $O$ ato de Criação.pdf>. Acesso em: 16 maio 2016.

DELEUZE, Gilles; GUATTARI, Félix. O que é a filosofia? Rio de Janeiro: Ed. 34, 1997.

FILOSOFIA NO ENSINO MÉDIO. V.2. Elementos didáticos para a experiência filosófica. Atta Mídia e Educação, São Paulo, 2007. Paulus, 1 DVD, 45min. col., português. DVD.

GALLO, Sílvio. A filosofia e seu ensino: conceito e transversalidade. Revista Ethica, Rio de Janeiro, v. 13, n. 1, p. 17-35, 2006.

GALLO, Sílvio. Deleuze e a educação. 2007. Disponível em: <http://www.ufjf.br/grupar/files/2014/09/deleuze_e_a_educacao_parte_um.pdf>. Acesso em: 10 jan. 2018. 
MATOS, Sônia Regina da Luz. Didática e suas forças vertiginosas. Conjectura, Caxias do Sul, v. 1, n. 14, p. 93-134, jan. 2009.

RIO GRANDE DO SUL. Seduc. Secretaria de Estado do Rio Grande do Sul. Departamento Pedagógico - DP. Proposta para o Ensino Médio Politécnico e Educação Profissional Integrada ao Ensino Médio- 2011-2014. Seduc-RS: Porto Alegre, 2011.

RIO GRANDE DO SUL. Seduc. Secretaria de Estado do Rio Grande do Sul. Departamento Pedagógico - DP. Reestruturação curricular para o Ensino Fundamental. Seduc-RS: Porto Alegre, 2016. 


\title{
PERFIL SOCIOANTROPOLÓGICO DOS ESTUDANTES DA ESCOLA PROFESSOR APOLINÁRIO ALVES DOS SANTOS
}

\author{
Bruno Rodrigues da Silva Damin - brunodaminrs@gmail.com \\ Deivid da Silva Ferrerira - deividsferreira95@gmail.com \\ Drieli Munique de Matos Tibola - dm1995matos@gmail.com \\ Gabriela Gonzalez Matias - gabigmtessaro@gmail.com \\ Letícia Turella Tonolli - Ittonolli09@gmail.com \\ Luciana Cassol da Silva - lucianacassol2015@gmail.com \\ Nátali Di Domenico Santos - domenico.natali@gmail.com \\ Rafael Pinheiro - rssouza20170@gmail.com \\ Suelen Cristina Boeck - scboeck84@gmail.com
}

Subprojeto Interdisciplinar (História e Sociologia) EEEM Professor Apolinário Alves dos Santos*

Resumo: O presente estudo tem por objetivo apresentar o perfil do estudante de Ensino Médio da Escola Professor Apolinário Alves dos Santos. A coleta dos dados foi realizada a partir de um formulário online contendo questões objetivas sobre aspectos econômicos, sociais, trabalho, vida escolar, saúde e lazer. Teve como principal objetivo identificar o contexto social em que o aluno está inserido, para que, assim, os educadores e todo o núcleo escolar possam trabalhar de forma mais próxima à realidade escolar. Os dados coletados foram analisados e ancorados em referenciais específicos relacionados aos temas, como o relatório do IBGE (2010), e Pierre Levy para o tema cibercultura na escola. A metodologia utilizada foi a coleta de dados, montagem e análise de gráficos com o auxílio de referências bibliográficas. Para a coleta de dados, os alunos foram levados para o laboratório de informática da escola, para responderem às perguntas contidas no formulário online. A dificuldade encontrada pelos estudantes foi conexão instável da internet disponível na escola. O grupo analisou as respostas transformadas em gráficos, e, a partir daí, foi realizado um estudo, com questões selecionadas pelos bolsistas, visando a atingir o objetivo citado acima. Como resultados do projeto foi possível identificar características do delineamento socioeconômico, as quais não são perceptíveis no cotidiano da sala de aula.

Palavras-chave: Perfil. Socioantropológico. Estudantes. Escola.

\section{Introdução}

Compreender o perfil do aluno ajuda o docente a identificar algumas peculiaridades dos jovens, as quais não identificamos no cotidiano da sala de aula; planejar uma aula conhecendo o perfil do estudante leva o docente a ir além do conteúdo. Verificando essas necessidades, os bolsistas do Pibid Subprojeto Interdisciplinar História e Sociologia, buscou alternativas para ampliar as perspectivas no diz que respeito ao planejamento didático.

\footnotetext{
* Coordenadora: Profa. Dra. Eliana Rela. Supervisora: Profa. Suélen Cristina Boeck.
} 
Para acompanhar o avanço tecnológico, os bolsistas elaboraram um formulário digital contendo questões de cunho socioeconômico, aplicado durante 2015, sendo que os estudantes foram levados ao laboratório de informática para responderem ao referido questionário. Após a coleta de dados, foi possível traçar os diversos perfis do aluno do Ensino Médio da Escola Professor Apolinário Alves dos Santos.

\section{Referencial teórico}

\section{Análise socioeconômica do grupo familiar}

Segundo os dados coletados a respeito da escolaridade e do trabalho dos alunos e dos pais, foi observado que a maioria dos pais tem o Ensino Médio completo (29,9\%); porém, quase a mesma porcentagem $(26,4 \%)$ não completou o Ensino Fundamental. Percebe-se que tanto os pais que terminaram quanto aqueles que tiveram que abandonar valorizam os estudos do(s) filho(s), mantendo-o(os) na escola. Apesar de ser pequena (1,5\%), e ainda assustar, é a quantidade de analfabetos; em contrapartida, 2,3\% possuem algum tipo de pós-graduação e $5 \%$ graduação.

Foi perguntado aos adolescentes em que a renda familiar é empregada. Muitos ainda não trabalham e não têm como saber exatamente seu destino. A análise dos dados indica que $59,4 \%$ são gastos nas contas da casa e $33 \%$ em alimentação; o restante é dividido em saúde, lazer, tecnologia e vestuário. Acredita-se que esse dado é muito impreciso, pois, na maioria das vezes, o adolescente escuta os responsáveis conversando sobre o assunto e a "casa" em si engloba o lar, a família de modo geral e todas as suas necessidades; não creio que haja um real interesse ou conhecimento.

Falando a respeito do lazer, uma das perguntas nos traz que quase a metade, $45,6 \%$, das famílias tira férias em algum lugar diferente ou sai frequentemente. Isso caracteriza a região serrana, por estar longe do litoral; a maioria da população goza seu tempo livre na praia. Também há muitas famílias que possuem familiares no interior, com chácaras e em outras cidades, esvaziando Caxias do Sul na época de veraneio. 


\title{
A cultura digital no ambiente escolar
}

Em pesquisa realizada com alunos do Ensino Médio da Escola Estadual de Ensino Médio Professor Apolinário Alves dos Santos, observou-se que 90\% dos alunos utilizam a internet como seu principal meio de comunicação. Outros $10 \%$ leem jornal, utilizam a televisão e o rádio para manterem-se informados.

Ao analisar estes dados, fica a seguinte pergunta: A escola e seus docentes estão preparados para tal avanço tecnológico?

A tecnologia e seu conteúdo devem fazer parte do dia a dia escolar; a escola deve acompanhar os avanços da tecnologia, e os professores devem receber formação adequada para sua utilização. Porém observamos outro problema que deve ser levado em consideração, o déficit de equipamentos e de meios para que tudo funcione, ou seja, uma internet com qualidade.

Segundo o documento Cultura Digital, da Série Cadernos Pedagógicos,

\begin{abstract}
assistir à televisão, usar o telefone celular, movimentar a conta bancária, verificar multas de trânsito, comprar produtos, trocar e-mail com pessoas que estão no outro lado do planeta, bem como pesquisar na enciclopédia Wikipédia (enciclopédia colaborativa, livre, multilíngue e online) e estudar a distância são hoje atividades cotidianas no mundo inteiro e também no Brasil. Na mesma proporção, toda uma cultura produzida migra para o digital e exige, de maneira complexa, ativa participação. Nossas identidades e vida dependem deste movimento, que é também social e cultural, justamente porque constrói uma rede de significados, compartilhados e legitimados neste contexto, sustentados e repetidos, que hoje fazem dos dispositivos tecnológicos seu instrumento principal de propagação. (LÉVY, 1999, p. 14).
\end{abstract}

A vida das pessoas, em especial dos adolescentes, está ligada à cultura digital. Os meios de comunicação interligam pessoas em todo o mundo. A internet deve, além desta "teia social", ser reconhecida como uma ferramenta na construção da aprendizagem. Hoje em dia, além do auxílio de livro didático, mapas e de outras ferramentas pedagógicas, muitas escolas já utilizam ferramentas digitais como aporte teórico para a construção da aprendizagem, para diversas áreas do conhecimento.

Por meio da pesquisa socioantropológica realizada na Escola Estadual de Ensino Médio Professor Apolinário Alves dos Santos, verificou-se que os alunos possuem uma forte ligação com o uso de mídias digitais, porém essas mídias 
digitais são pouco utilizadas por professores, pois estes não possuem formação adequada para seu uso.

Verificou-se que a escola possui um amplo e completo laboratório de informática, e em torno de 30 netbooks para uso pedagógico em sala de aula. Entretanto, a escola não possui acesso com qualidade à internet, dificultando a utilização desses meios de comunicação digital.

Outro problema verificado é o preconceito e medo que alguns professores têm ao utilizar meios digitais em sua prática docente, muitas vezes marginalizando a prática do uso.

\begin{abstract}
A escola necessita reorganizar o seu trabalho, seu planejamento, sua coordenação coletiva, reconstruir a relação entre o sujeito e o conhecimento, para subverter a lógica que separa pessoas e saberes, prazeres e descobertas, respeito e diferenças. Reconhecer que democracia, solidariedade e liberdade devem orientar o trabalho pedagógico. Há ainda que se considerarem as novas formas de ensinar e aprender que, a exemplo da transcendência espacial, requerem a conexão com as novas realidades do tempo presente, como o diálogo com as novas tecnologias. Lévy (1999) nos alerta que qualquer projeção a ser feita sobre o futuro da educação e das sociedades deve considerar as novas relações com o saber, dada a velocidade com que os saberes são renovados e os meios que estão a esse serviço. (BUSTAMENTE, 1999, p. 14).
\end{abstract}

Como perspectivas futuras para a utilização de meios digitais, professores devem ter uma formação continuada em mídias digitais e em sua utilização como ferramenta pedagógica em sala de aula. Devemos desmitificar o (pré)conceito de que o aluno não aprende por meio de mídias digitais, e que a cultura digital deve fazer parte do cotidiano escolar.

\title{
A rotina dos secundaristas
}

Segundo os dados levantados pelo questionário, no núcleo que diz respeito à rotina dos estudantes, percebeu-se que 34,9\% deles também trabalham; porém, bem próximo a esse percentual, há registro de que $31 \%$ destes não o fazem para ajudar a família (apenas 5,8\%), mas sim por vontade de serem independentes. Isso está ligado ao resultado da questão que pedia para definir essa geração. Então 36,8\% definiram-se como consumistas, indicando que a cultura capitalista influencia seu modo de perceber 
prioridades. O que reforça a constatação de que os alunos da escola pertencem à classe média, já que os outros $65,1 \%$ não trabalham.

Porém, um contraponto digno de nota são as horas semanais dedicadas ao estudo. Segundo os dados, $44,1 \%$ dedica apenas 1 hora de sua semana aos estudos, seguidos de $29,9 \%$ que não dedicam seu tempo para o estudo. 0 percentual que estuda de duas a três horas é $22,6 \%$, entre quatro e cinco horas é $3,4 \%$ e informou que estuda mais de cinco horas $1,9 \%$. Estariam os jovens se focando mais no apelo materialista da nossa sociedade? Existe, afinal, uma contradição nestes números, que fazem parecer com que as profissões escolhidas não necessariamente precisam do conhecimento empírico que a escola fornece. Seria esse um indício de que a estrutura do sistema educacional atual não comporta mais a realidade social dos estudantes? Ou que, talvez, o Ensino Médio seja banalizado dada a facilidade com que um aluno é passado de série e que as matérias disponíveis são conhecimentos relevados muito mais por aspirações e afinidades, do que por sua importância como educação formadora? A partir de quando perdemos nossos alunos para o mercado de trabalho?

Outro indício da desestruturação na percepção dos jovens, em relação a prioridades e relevâncias são os 10,7\%, que responderam na definição de geração com responsável. Como uma geração sustenta sua vontade de autonomia, se ela não acredita ser responsável? É desanimador perceber a discrepância entre a vontade de trabalhar e a de estudar.

Outro fator preocupante diz respeito às horas de sono: $44,1 \%$ dormem de 4 a 7 horas por dia, menos do que o recomendado para essa fase de desenvolvimento. Somados aos $20,7 \%$ que dormem mais de oito horas, os $64,8 \%$ dos dados condizem com os $65,1 \%$ que não trabalham. São apenas $33 \%$ que dormem as oito horas; um número que se equipara aos $34,9 \%$ que trabalham. A questão que fica aqui seria: Quanto dessa porcentagem que trabalha e dorme bem tem tempo para estudo e lazer? E por que uma quantidade tão expressiva, quanto aos $72 \%$ que não dedicam significativamente seu tempo aos estudos, pode estar tão próximo dos $65,1 \%$ que não trabalham? A que nível de desinteresse os alunos chegaram em relação à educação e ao conhecimento? Muito embora a internet seja uma ferramenta idealisticamente educativa, apenas $2,2 \%$ a utilizam para pesquisa. $69 \%$ é pra redes sociais, ou 
seja, a escola para o jovem é muito mais um meio de socialização do que de educação. Essa hipótese pode ser sustentada pelos $8 \%$ que responderam como interesse a educação.

Perante essas informações, percebemos que as construções sociais da contemporaneidade afastam cada vez mais os jovens do aprendizado, colocando-os rumo a uma vida adulta precoce. As exigências e expectativas criadas para os adolescentes, juntamente com a idealização do desejo de satisfação ser constantemente atendido, molda esses jovens em mecanismos de produção e demanda. O sono e a educação ficam em segundo plano, mas nunca desejos mais íntimos deixarão de serem atendidos.

\section{Papel do gênero no ambiente familiar}

$\mathrm{Na}$ pergunta sobre quem era o responsável pelo aluno, $67,4 \%$ responderam a mãe. Sendo que $58 \%$ dizem morar com pai e mãe, em contraste com $26,8 \%$ que declaram morar com apenas a mãe ou mãe e irmãos. Sendo assim, percebe-se que a figura materna se faz presente em $85 \%$ das moradias e são responsáveis em $67,4 \%$ delas. Ou seja, em $21,9 \%$ dos lares, muito embora haja uma estrutura familiar tradicional, a responsabilidade pelos filhos recai sobre a mãe. A hipótese que podemos estabelecer com estes dados seria de que, muito embora vivamos numa sociedade patriarcal, ser pai significa ser o provedor da família. Na pergunta sobre a profissão que o responsável exerce, houve um rompimento com o perfil dito feminino como responsável, pois $38,3 \%$ dos estudantes responderam indústria. Aqui levantam-se duas possibilidades, ou por Caxias do Sul ser um polo industrial, o gênero não faz diferença para exercer a profissão ou a percepção de responsabilidade recai sobre a economia. Um dado mais substancial são os $21,8 \%$ que se consideram autônomos, o que releva menos a questão de gênero.

Ante isso, fica a pergunta: Qual é o verdadeiro significado de ser responsável pela família, na percepção dos jovens? E o que faz com que os homens se distanciem tanto do ambiente escolar, afinal apenas $26,1 \%$ são ditos como responsáveis num todo, mas apenas $4,2 \%$ moram apenas com o pai. 


\section{Estrutura do grupo familiar}

O conceito de família tem mudado ao longo da História, o que demonstra que essa ideia não é imutável e natural para o ser humano. Assim, a família se modifica de acordo com as necessidades de cada agrupamento social no seu tempo e espaço. Atualmente, com o maior debate acerca das questões de gênero e uma superação por parte da juventude de alguns dos valores conservadores e tradicionais, que regiam as sociedades ocidentais, baseados também no forte senso de religiosidade, a ideia de família tem se tornado mais ampla em várias configurações; apesar de ainda vistas com reservas por determinados setores da sociedade, estão cada vez mais sendo aceitas plenamente como famílias. Sobre essas mudanças e a reação a elas por alguns grupos conservadores, as autoras Cláudia Moraes e Silva Pereira e Edina Schimanski afirmam:

\footnotetext{
Embora a diversidade na formação familiar esteja clara na contemporaneidade, as normas e regras estipuladas não deixaram de existir. Ao não conseguir encontrar o equilíbrio entre as normas "ideais" e a flexibilidade e mudança, persiste a construção do modelo hegemônico e tradicional de família, bem como a reivindicação social de tal modelo. A instituição familiar está imersa em um processo de normatização que cria um universo simbólico em torno de um discurso hegemônico do que é considerada uma família ideal. (PEREIRA; SCHIMANSKI, 2013, p. 165).
}

Segundo a questão sobre as pessoas com quem os estudantes moram, a maior parte dos alunos $(58,2 \%)$ vive com o pai e a mãe, o que demonstra que as famílias atendidas pelo turno da manhã da escola Apolinário seguem esse modelo dito tradicional de família, com pai, mãe e um ou dois filhos, já que outra questão demonstra que o número médio de membros em cada família é de 3 a 4 pessoas.

Em relação à moradia $77,7 \%$ das famílias dos alunos possui casa própria. É um número semelhante ao demonstrado em outra questão, que mostra que 75,6\% dos estudantes mora em Caxias do Sul há mais de 5 anos. Isso nos faz pensar que as famílias levam certo tempo para adquirir sua moradia própria, após chegar na cidade. Os dados são compatíveis com os do IBGE (dados de 2013), segundo os quais $74,5 \%$ dos domicílios brasileiros pertencem à família que nela habita. Esses dados nos fazem crer que os programas sociais do governo federal, como o Minha Casa, Minha Vida, proporcionaram resultados 
satisfatórios, associados ao crescimento da economia brasileira nos últimos anos, o que aumentou o número de empregos, apesar da crise vivida atualmente.

Analisando os dados do IBGE, no Censo de 2010, sobre a população da cidade, temos que, dos estão 435.564 habitantes, 37.437 pessoas com 5 anos ou mais não viviam em Caxias do Sul no mês de julho de 2005. Os dados do nosso questionário, aplicado em 2015, indicam que 24,4\% dos estudantes do turno da manhã, da Escola Apolinário vivem em Caxias do Sul há menos de cinco anos. Isso indica um expressivo aumento na migração para a cidade de Caxias do Sul, provavelmente motivado pelas questões econômicas, como a busca por um emprego e moradia, já que Caxias do Sul é conhecida por ter um alto número de indústrias e de empregos, na área de comércio e serviços. Além disso, vale ressaltar a recente imigração para a nossa cidade, principalmente de pessoas oriundas do Haiti e do Senegal. Porém, a escola ainda não atende pessoas destes grupos de imigrantes.

O fato de $96,2 \%$ das famílias terem acesso a saneamento básico, segundo nosso questionário, mostra que não somente o sonho da casa própria foi conquistado por boa parte das famílias, mas que elas conseguem viver com dignidade e boas condições de vida. O estudo também mostra que 85,1\% das famílias atendidas pela Escola Apolinário, no turno da manhã, realizam a separação do lixo reciclável, o que demonstra tanto que a coleta do lixo realizada pela empresa, pertencente ao Poder Público é eficiente, e que as famílias têm a noção de que essa separação e esse cuidado terão uma finalidade positiva para o meio ambiente da cidade, beneficiando, assim, seus cidadãos.

O estudo também demonstrou que $63,2 \%$ dos alunos do turno da manhã, da Escola Apolinário, declaram usar o carro da família como o principal meio de transporte. Transporte público (ônibus) é usado por 33\%; 1,5\% utilizam motocicleta, e os restantes $2,3 \%$, outros meios de transporte. Provavelmente os estudantes consideraram, para responder essa questão, o meio de transporte utilizado pela família em seus passeios ou viagens, sendo pouco provável que esse expressivo número utilize carro para ir até a escola. Quem está presente em algum horário de chegada ou saída na escola, percebe que a maioria utiliza ônibus, vans particulares ou vai até a escola e volta para casa a pé. 
A questão também demonstra que o carro ainda é muito bem visto pela maioria das famílias, que buscam possuir um para utilizá-lo sempre que possível. Isso pode ser causado tanto por uma visão materialista, ainda muito presente em nossa sociedade, como pelo fato de o serviço de transporte público ser ineficiente na maioria dos bairros.

\section{Conclusão}

O eixo central foi identificar o perfil do estudante, analisando os respectivos resultados com base na coleta de dados, submetida através de um formulário eletrônico. Consequentemente, trata-se de um trabalho coletivo entre professores, alunos e pibidianos, para desenvolver uma análise socioantropológica do grupo escolar.

As conclusões obtidas por meio da coleta de dados assim resultaram: $67,4 \%$ dos sujeitos tinham a mãe como responsável e $85 \%$ têm a figura materna presente no cotidiano familiar, destacando a figura feminina como responsável pela vida e formação dos estudantes.

No final do nosso trabalho, percebemos que a escola abrange muito mais do que o ensino e a educação. $O$ aluno não é um objeto pronto, com ele existe uma série de complexidades que abrangem o social, econômico e comportamental.

Observamos a importância de educadores conhecerem a realidade e complexidade do aluno, suas limitações, sua vida e seu cotidiano, sendo fundamental o estudo social com a comunidade escolar. Contudo, todo esse conhecimento deve ser aplicado dentro da escola, para que a convivência possibilite conhecer o indivíduo que há, por trás de todo aluno, cada aprendizagem é enriquecedora, tornando-o mais eficaz e produtivo.

Por isso, nosso trabalho cumpriu sua função, a de conhecer a realidade escolar e, assim, possibilitar que entendamos as particularidades da escola, dando vazão para que o trabalho docente como um todo, desde a construção do Plano Político-Pedagógico à elaboração de planos de aula e em todas as atividades envolvendo a comunidade escolar, seja a mais adequada ao contexto que a cerca. 


\section{Referências}

BRASIL. Projeto Escola na Cultura Digital. Subsecretaria de Modernização e Tecnologia da Secretaria de Educação do Distrito Federal (SUMTEC). Disponível em:

<http://www.participa.br/escola-na-cultura-digital>. Acesso em: 11 jul. 2016.

LEVY, Pierre. Cibercultura. São Paulo: Ed. 34, 1999.

LIMA, Márcio Roberto de. Cultura digital e escola: pesquisa e formação de professores. Revista e-Curriculum, São Paulo, v. 13, n. 1 p. 183-189, jan./mar. 2015. Disponível em: <http://revistas.pucsp.br/index.php/curriculum/article/viewFile/13324/16389>. Acesso em: 11 jul. 2016.

PEREIRA, Cláudia Moraes e Silva; SCHIMANSKI, Edina. Família, Gênero e Novas Configurações Familiares: um olhar sobre a mulher e a condição de pobreza. Revista Magistro, Duque de Caxias, v. 8, n. 2, p. 163-178, 2013. 
PIBID/INTERDISCIPLINAR - UCS: UM OLHAR A PARTIR DA MEDIAÇÃO DOCENTE

\author{
Márcio Rodrigues* \\ mrodrig4@ucs.br \\ Subprojeto Interdisciplinar (História e Sociologia) \\ EMEF Governador Leonel Brizola
}

\begin{abstract}
Resumo: $O$ presente artigo apresenta as reflexões deste professor na condição de supervisor de acadêmicos de licenciaturas em História e Sociologia, no programa Pibid-UCS, no período de agosto de 2016 a dezembro de 2017, na Escola Municipal de Ensino Fundamental Governador Leonel Brizola, em Caxias do Sul, RS, na qual atuo como professor de História e Geografia. O fio condutor das reflexões se dá a partir de um paralelo comparativo que faço entre as experiências vividas pelos estudantes no programa, em comparação à minha própria trajetória, quando estudante de graduação. Assim busco demonstrar a importância do programa, como promotor de experiências no cotidiano de uma escola de tempo integral a estudantes, futuros professores, desde o início da respectiva graduação; e evidenciar que estes estudantes, no final, estarão mais familiarizados com o ambiente escolar - e, por conseguinte, mais preparados - do que este professor estava quando iniciou sua carreira. Sobretudo, em razão das experiências proporcionadas pelo programa, que permitiu, assim, problematizar e refletir a prática docente de um ponto de vista muito privilegiado: ao lado de um professor em sua atuação ao referido período com todas as suas falhas e acertos.
\end{abstract}

Palavras-chave: Pibid. Prática docente. Experiência. Reflexão. Escola tempo integral.

\title{
Pibid/Interdisciplinar - UCS: um olhar a partir da mediação docente
}

O presente texto é uma reflexão que se dá a partir da minha experiência como supervisor de acadêmicos de História e Sociologia, dentro do programa Pibid-UCS. Essa experiência iniciou em agosto de 2016 e foi até dezembro de 2017, na Escola Municipal de Ensino Fundamental Governador Leonel Brizola, em Caxias do Sul, RS. Escola em que atuo como professor de História e Geografia desde 2016.

Inicialmente, apresentarei, de forma breve, a escola e a comunidade que ela atende. A seguir, há uma reflexão, na qual traço um paralelo entre a minha experiência enquanto acadêmico, no final da minha graduação, em oposição à experiência vivida pelos acadêmicos no programa Pibid/Interdisciplinar - UCS, buscando evidenciar a importância deste programa, como promotor de

\footnotetext{
* Mestrando em História pela Universidade de Caxias do Sul (UCS). Coordenadora do subprojeto: Profa. Dra Eliana Rela. Supervisor: Prof. Mário Rodrigues.
} 
problematizações da realidade escolar a acadêmicos, futuros professores. Por fim, encaminho o texto às reflexões finais.

\section{Da escola, da comunidade e dos educandos}

A escola Governador Leonel Brizola foi criada em 2014. Seu nome evoca o do eminente político gaúcho, que tinha na Educação uma de suas principais bandeiras. Assim, na gestão municipal compreendida entre 2013 a 2016, o PDT, partido que ocupava a prefeitura da cidade - e fundado por Brizola -, criou a escola que traz seu nome. Por razões que não serão discutidas aqui, porém, a escola ainda não foi construída. Desde o seu início, "em caráter temporário", a escola está localizada nos dois primeiros andares do Bloco J do campus-sede da Universidade de Caxias do Sul (UCS).

Por outro lado, distante $4 \mathrm{~km}$ do campus-sede da UCS, localiza-se a Comunidade Campos da Serra, o maior conjunto de moradias populares de Caxias do Sul, construído na esteira do programa federal Minha Casa Minha Vida. A fim de suprir a considerável distância entre a comunidade e a UCS, a prefeitura fornece, desde o início das atividades da Governador Leonel Brizola, transporte escolar gratuito para todos os educandos de ida e volta entre o Loteamento e a Escola.

Além de ser uma escola jovem e não estar inserida na comunidade a que atende, ela apresenta ainda outra peculiaridade: trata-se de uma escola de Tempo Integral. A proposta de escola de Tempo Integral compreende

\footnotetext{
a Educação como uma articulação entre sujeitos, tempos e espaços, com as mais diversas características, necessidades e aprendizagens ao longo da vida. Considera os sujeitos em sua condição multidimensional (física, cognitiva, intelectual, afetiva, social e ética), inserido num contexto de relações. Espaços, tempos, dinâmicas e sujeitos são os protagonistas de seu aprendizado. [...] Portanto, a escola de tempo integral busca cumprir com sua função social e harmoniosa de todos os envolvidos, por meio de uma opção filosófica e ética, socioantropológica, epistemológica e pedagógica dos cidadãos da comunidade escolar baseada na gestão democrática que garanta o acesso, o sucesso e a conclusão do ensino fundamental com qualidade para todos os seus estudantes. (Projeto Polítıco-PedagóGico, 2014, p. 7).
} 
Desta maneira, os educandos chegam à Governador Leonel Brizola às 8 horas e ali permanecem até às 17 horas. Contam com salas temáticas, e quem se desloca pelo espaço físico da escola, de uma sala para outra, são os próprios educandos. Embora seja uma escola pequena, com apenas oito salas de aula, a escola proporciona de forma regular oficinas ofertadas pelos professores sobre várias temáticas, que vão além dos conteúdos escolares.

A Governador Leonel Brizola surgiu para atender às crianças que residem no Loteamento Campos da Serra. Apesar de alguns anos já percorridos, tanto a escola quanto a comunidade ainda estão no início de uma caminhada. Por serem "jovens", escola e comunidade têm grandes desafios pela frente. No primeiro caso, a própria questão de estar em um local que não é o da comunidade e a sua indefinição de quando virá a ser construída nesta comunidade é uma incógnita que depende de recursos financeiros e de vontade política. No segundo caso, tem se destacado com recorrência, no principal periódico da cidade, questões relativas à violência e a drogadição, por exemplo. Sublinho que, embora seja uma escola com muitas peculiaridades, que a diferenciam em relação às demais em muitos aspectos, ela se aproxima de uma escola pública de periferia, o que de fato, aliás, ela é. E, apesar da administração pública não suprir com celeridade as necessidades que uma escola pública no molde integral requer, a equipe diretiva, a coordenação, os professores e funcionários têm atendido às crianças da melhor maneira possível. Para além das adversidades, as conquistas atingidas nesta breve caminhada reforçam meu orgulho de compor o quadro de professores da Leonel Brizola.

\section{Do Pibid/Interdisciplinar - UCS}

Olhando agora para toda a caminhada que foi realizada, busco uma síntese do que vivi dentro do programa Pibid/Interdisciplinar - UCS, como supervisor de acadêmicos de História e Sociologia da Universidade de Caxias do Sul; acadêmicos que acompanharam e participaram das minhas aulas entre agosto de 2016 até dezembro de 2017.

Dito isso e, afinal, passando as minhas reflexões comparativas, recordo-me do meu último semestre no curso de História, no segundo semestre de 2006. Estava prestes a iniciar meu estágio supervisionado, a poucos passos da porta da 
sala de aula de um 3ㅇa ano do noturno. Meu coração parecia querer sair pela boca; sede como nunca havia sentido até aquele momento e uma insegurança crescente - apesar de ter o conteúdo na ponta da língua. Recordo que havia protelado os estágios supervisionados para o último semestre, pois tinha priorizado todas as disciplinas teóricas e pedagógicas. Na minha lógica, estaria, portanto, apto e seguro para realizar os estágios. Ledo engano.

Em comparação com os cinco acadêmicos ${ }^{1}$ que me acompanharam nesta trajetória do Pibid/Interdisciplinar - UCS, acredito que eles estarão mais seguros do que eu estava na conclusão da minha graduação. A todos eles foi oportunizada a possibilidade de estarem diante das turmas, nas quais leciono, como professor. Aliás, apresentei-os como professores, meus colegas - e nunca como estagiários.

Um dos pressupostos do papel de supervisor de um grupo de bolsistas Pibid é auxiliar no desenvolvimento de competências didáticas e pedagógicas, para promover a autoconfiança destes futuros docentes. No contexto da prática de supervisão, tem-se apontado uma série de questões para serem pensadas ao longo da trajetória de formação docente. A literatura tem focado na importância curricular e de conhecimentos de conteúdos, que o professor tem que dominar, mas muito pouco se trata da dimensão interacional desse sujeito e dos sentimentos por ele experimentados em seu processo de formação.

Conforme Rela (2010), os aspectos humanos e relacionais, envolvidos no processo de formação de professores, revelam a complexidade do fazer pedagógico. Daí resulta a importância de o professor em formação e o supervisor, como facilitador do desenvolvimento pessoal e profissional daquele, refletirem acerca dos receios que envolvem a própria formação inicial.

Nos encontros de formação, para os supervisores deste subprojeto, tomouse como ponto de partida os conceitos de supervisão e supervisor no pensamento de Alarcão et al. (1996), por apresentar cenários de supervisão e formação conferidos por dimensão pedagógica ao termo. No pensamento da pesquisadora, supervisão é um processo em que um professor, em princípio, mais experiente e mais informado, orienta outro professor ou candidato a professor no seu desenvolvimento humano e profissional. No cenário

\footnotetext{
${ }^{1} \mathrm{Na}$ verdade, ao todo foram oito. Ao longo da caminhada, três estudantes tiveram que deixar o programa e foram, por isso, substituídos por outros três estudantes.
} 
apresentado, o supervisor é percebido como alguém que auxilia, acompanha, cria condições de sucesso, orienta o desenvolvimento de aptidões e capacidades.

Além das aulas, aos estudantes foi possibilitado propor e organizar as oficinas no componente de História e Geografia sob minha supervisão e que ocorrem regularmente na escola. Nesta senda, foram várias oficinas. A saber, por exemplo, sobre o viajante genovês Marco Polo; outra sobre a História do Rap e Hip Hop que contou com a presença do MC Nego Boy; oficina de Fanzines; outra acerca do livro Meu avô tem oito anos, da escritora carioca Sônia Travassos. Houve ainda oficinas de confecção de máscaras africanas, no contexto da Semana da Consciência Negra que, igualmente, foi organizada e executada pelos pibidianos, em parceira com os demais professores da escola. Incluídas aqui as palestras de abertura e encerramento desta semana de atividades, que convidou a pensar a negritude no Brasil contemporâneo, no âmbito da escola.

Além disso, dentro dessa trajetória com os acadêmicos do Pibid Interdisciplinar/UCS foram realizadas, como estratégia, diversas saídas a campo, com o objetivo de estudo do meio. Conforme Anastasiou e Alves (2015), essa estratégia é um estudo direto do contexto social e natural no qual o estudante se insere, visando a uma determinada problemática de forma interdisciplinar. Proporciona a construção do conhecimento de forma direta, por meio da experiência vivida.

A primeira delas foi a participação no programa vereador por um dia, na Câmara de Vereadores de Caxias do Sul. ${ }^{2}$ O educando que representou a nossa escola foi preparado em uma sessão simulada organizada pelos próprios pibidianos, e que foi realizada no auditório da escola. Não apenas os alunos, mas os acadêmicos e eu aprendemos muito acerca do trabalho desempenhado pelo Legislativo. Houve também saídas a campo ao: Museu da Força Expedicionária Brasileira (FEB), Memorial Valter Gomes Pinto e Escola de Formação Profissional Marcopolo (EFPM); Instituto Hércules Galló e Vila Operária, em Galópolis, além do encontro com a autora carioca Sônia Travassos na Casa da Cultura.

\footnotetext{
${ }^{2}$ Neste projeto, um educando, representando sua escola, tem a oportunidade de participar de uma sessão solene na Câmara de Vereadores de Caxias do Sul. Nela, ele "legisla" propondo projetos, leis e realizando discussões, tais como as que ocorrem com os vereadores.
} 
Ações, como as da condução das aulas, das oficinas ou das saídas a campo ou da organização da Semana da Consciência Negra, ${ }^{3}$ proporcionaram aos acadêmicos do Pibid, oportunidades para viver "na prática" os desdobramentos do que foi previamente planejado nas reuniões periódicas, que sempre ocorreram às segundas-feiras de manhã, na sala 207 na escola Governador Leonel Brizola, durante a vigência do programa. As ações eram planejadas e executadas, e as experiências eram discutidas no encontro seguinte. Eram externadas as expectativas e o que de fato aconteceu: acertos e erros. O que poderia ter sido diferente e, talvez, melhor. E assim por diante. Em suma, a prática docente foi refletida. Este foi um exercício que se constituiu em uma fonte rica, para pensar e repensar a formação docente destes futuros professores. E é nesse ponto que o programa Pibid torna-se um instrumento muito válido para a qualificação de futuros docentes na Educação do Brasil.

Pimenta e Lima (2004) ressaltam que a base dos processos de reflexão, na formação de professores, é constituída a partir dos saberes construídos na prática, que articulados à fundamentação teórica promovem a tão desejada tessitura da práxis. Nesse sentido, estabeleço inevitável comparação com a minha formação, excetuando os estágios supervisionados que realizei, não houve outro contato com a realidade escolar. Meu contato se deteve, sobretudo, à sala de aula. Diversamente, os acadêmicos do programa Pibid me acompanharam nessa trajetória, houve uma grande variedade de experiências que Ihes foram oportunizadas. Em alguns casos, muito antes dos estágios supervisionados que prenunciam os momentos finais da licenciatura.

Ressalta-se ainda que, como supervisor, aprendi muito com os conhecimentos que me foram oportunizados na rica convivência com os pibidianos. Da mesma forma, precisei estar disposto a ouvir opiniões, abrir-me ao novo, a sugestões, ideias, etc. No início, inclusive, sentia-me desconfortável lecionando para as minhas turmas, com um acadêmico me assistindo com os educandos. Às vezes, a situação se invertia e, quando percebia no rosto de um pibidiano certo desconforto no seu semblante, deliberadamente saía da sala, a

\footnotetext{
${ }^{3}$ Algumas das oficinas e todas as saídas a campo, das quais o Pibid/Interdisciplinar - UCS participou, estão registradas em Álbuns na página do Facebook da escola Governador Leonel Brizola.
} 
fim de dar esse espaço ao pibidiano. Era um momento seu. Uma experiência sua. Mais uma vez a ideia de empoderar os acadêmicos.

Em suma, a proposta do programa Pibid foi uma iniciativa louvável, que partiu do governo federal. Foi um acerto no sentido de qualificar o quadro de professores ao mergulhar estudantes de licenciaturas no mundo escolar muitas vezes, já no início da graduação. Por meio deste programa, a distância entre a academia e a escola diminui consideravelmente. O que, acredito, é fundamental para refletir os problemas que atravessam a Educação, que não são poucos e, segundo penso, são crescentes no século XXI. A diminuição da distância entre a academia e a realidade escolar é vital para o enfrentamento dos desafios pelos quais passa, sobretudo, a escola pública brasileira.

Sublinho as palavras de Seffner (2010), em um trecho que explica o que busquei proporcionar aos acadêmicos sob minha supervisão.

\begin{abstract}
Os saberes da docência são em geral saberes de caráter prático. Constituem aquilo que um professor aprende ao longo dos anos de exercício docente, saberes muito diversos, em geral pouco sistematizados e pouco refletidos, pouco discutidos, pouco valorizados, mas essenciais para a gerência e condução das aulas e para a "sobrevivência" do professor no ambiente escolar. São [...] as ações para manter a atenção dos alunos, os estratagemas para gerenciar conflitos e violências na sala de aula, [...] as sutilezas das regras disciplinares e do regimento e sua aplicação em benefício da boa condução das aulas, os meios e os modos de conversar com os pais ou responsáveis, os procedimentos de exposição dos conteúdos, o conhecimento de fontes para exercícios e testes [...] a percepção do valor que tem o conhecimento para alunos e pais e os meios de usar melhor essa informação para atingir os objetivos das aulas [...] e um conjunto diverso e amplo de modos, meios e estratégias e conhecimentos de natureza pedagógica, prática e vivencial. (SEFFNER, 2010, p. 215).
\end{abstract}

Essa ponderação é importante, pois assinala que minha preocupação sempre foi demonstrar aos acadêmicos como é uma escola de fato. De acordo com Seffner (2010), preocupei-me com questões práticas, tanto em sala de aula quanto fora dela. Quero dizer com isso que, tão importante quanto o conhecimento em profundidade do campo do conhecimento que eles - os pibidianos - propuseram-se estudar, ao longo de alguns anos, em um curso de graduação são, ainda, importantes os relacionamentos interpessoais e profissionais que são realizados dentro do mundo escolar. Entre outras coisas, 
cultivar um bom relacionamento com os educandos e ser ponderado com todos ao seu redor. Afinal, por vezes, o imponderável acontece. E o professor deverá lidar com isso de forma adequada. Cada caso é um caso que deve ser analisado de modo concreto.

Hoje, pelas redes sociais, são recorrentes vídeos que evidenciam ações de educadores, que ficam aquém da postura que se espera de um profissional. Assim, mais de uma vez, busquei problematizar a postura que cada um dos acadêmicos desempenhará como futuro educador. Um professor tem um impacto muito grande na vida de seus educandos. Conforme Freire (1997), é preciso respeito e cuidado para utilizar essa influência de forma a ajudar seus educandos e não tornar as coisas ainda piores.

Quanto à disciplina de História e sua metodologia de ensino em sala de aula, os acadêmicos que partilharam minhas aulas notaram que vários conteúdos iniciaram em uma linha do tempo. É através dela que faço relações com outros tempos e espaços. No século XVII, na Inglaterra, por exemplo, está ocorrendo o enfrentamento ao absolutismo monárquico. Mas o que ocorre simultaneamente na Europa continental? E na América do Norte? São relações interessantes que podem ser feitas e que, mais tarde, municiar-me-ão para abordar a Independência dos EUA, o lluminismo e a Revolução Francesa. É na linha do tempo que posso demonstrar as rupturas e permanências nos vários tipos de duração dos processos históricos. Neste exemplo, posso problematizar a impossibilidade da ocorrência da Revolução Industrial, caso não houvesse ocorrido a ascensão burguesa, que irá ao cabo da Revolução Gloriosa submeter o poder monárquico e, assim, por freio, as arbitrariedades reais, abrindo espaço para um cenário político estável nas ilhas britânicas.

Ressalto, porém, que ensinar História é muitas vezes - senão o tempo todo - ensinar conceitos. Estes, não raro, são complexos aos olhos de uma criança ou adolescente. E, nem sempre, são objeto de interesse de um estudante. Contudo, todos os assuntos são importantes. Deve o professor conhecer em profundidade sua matéria e saber explicar aos seus educandos a razão pelas quais eles devem aprender sobre determinado tema. Algumas vezes, porém, percebe-se que um educando pode manifestar-se pouco interessado no que esta sendo falado, já que há problemas anteriores à escola e que refletem-se nele. Mas há um acordo tácito em razão do papel social que cada um de nós cumpre na sala de aula. 0 
meu papel de professor me orienta a defender com altruísmo o conteúdo que estou ensinando, ainda que eu saiba, por conhecer um pouquinho da realidade do meu educando - ou pensar que conheço -, que aquele conteúdo não diga nada para ele naquele momento e, pior, talvez nunca dirá. A este educando, por seu termo, cabe aceitar o que digo com base na autoridade que represento naquela posição de professor. Aos pibidianos busquei demonstrar a importância de conhecerem seus educandos; de ser um professor humano, tolerante, solidário e, talvez, não tão pretensioso, a ponto de achar que a sua disciplina deva ser apreendida por todos os que o cercam. É salutar aceitar isso. Enquanto alguns gostam muito da sua matéria, outros educandos gostam mais de outras e, portanto, se saem melhor nelas.

\section{Conclusão}

Tive o privilégio de poder participar como supervisor de estagiários de História e Sociologia da UCS, em aulas da escola em que leciono. Aprendi muito com todos os acadêmicos. Trouxeram muitas informações novas de coisas que desconhecia. O programa Prezi foi um exemplo. Antes do Pibid, jamais soube o que era um fanzine. Não conhecia o Hip Hop e sua postura combativa e engajada. O verbo "empoderar" foi incorporado ao meu vocabulário. As visitas realizadas ao Museu da FEB e ao Instituto Hércules Galó foram guiadas pelas monitoras que, ao mesmo tempo, faziam parte do grupo do Pibid que supervisionei. Aprendi muito nesses espaços de memória com elas. Foram acadêmicos muito qualificados com os quais tive a grata oportunidade de conviver. Com eles lembrei que, quando concluí minha graduação, queria mudar o mundo. Hoje, estou um pouquinho mais maduro, talvez um pouco mais cético, mas buscando manter acesa a chama da esperança de que, como professor, e que alimento dentro de mim, posso fazer a diferença para meus alunos. Às vezes um sorriso, um elogio, um abraço ajudam tanto quanto compreender a Revolução Francesa e os impactos dela nas Constituições do mundo contemporâneo.

A Educação é um campo muito fluído, mutável e que se transforma ao sabor das mudanças culturais e tecnológicas, principalmente. Penso que, tão importante quanto saber História, Geografia, Sociologia, Filosofia ou Literatura, 
por exemplo, é a postura do educador frente às turmas, aos pares, aos pais e que, cada vez mais, será requerido destes futuros profissionais maior desenvoltura para lidar com as situações que lhes são postas. Diante desse quadro, a realidade é muito mais rica e complexa do que se almeja analisar, ler e compreender. $E$, por vezes, a humildade em reconhecer que não sabemos tudo e que jamais saberemos me faz ter a certeza de que é preciso estar aberto ao novo e reaprender sempre. E isso não é simples. Em suma, é necessário ser - como já dizia o "Maluco Beleza" Raul Seixas, lá nos idos de 1973 - uma metamorfose ambulante.

\section{Referências}

ANASTASIOU, Léa das Graças Camargo; ALVES, Leonir Pessate (Org.). Processos de ensinagem na universidade: pressupostos para as estratégias de trabalho em aula. Joinville: Ed. da Univile, 2015.

FREIRE, Paulo. Pedagogia da autonomia. 6. ed. Rio de Janeiro: Paz e Terra, 1997.

PIMENTA, Selma Garrido; LIMA, Maria Socorro Lucena. Estágio e docência. São Paulo: Cortez, 2004.

PROPOSTA PEDAGÓGICA de Educação Integral em Escola de Tempo Integral para a Etapa da Educação Básica no Ensino Fundamental e da Modalidade da Educação Especial da Escola Municipal de Ensino Fundamental Governador Leonel Brizola. Caxias do Sul, RS, 2014.

RELA, Eliana. Avaliação no estágio supervisionado: intersubjetividades na formação de professores em cursos na modalidade EAD/Eliana Rela. Orientadora: Profa. Dra. Marie Jane Soares Carvalho. Porto Alegre: UFRGS, 2010.

SEFFNER, Fernando. Saberes da docência, saberes da disciplina e muitos imprevistos: atravessamentos no território do ensino de História. In: BARROSO, Véra Lucia Maciel et al. (Org.). Ensino de história: desafios contemporâneos. Porto Alegre: EST; Exclamação; Anpuh/RS, 2010. p. 213-229. 
13

SAÍDAS A CAMPO COMO ESTRATÉGIA PARA O ENSINO INTERDISCIPLINAR

\author{
Geovana Erlo* \\ gerlo2@ucs.br \\ Subprojeto Interdisciplinar (História e Sociologia) \\ Escola Municipal de Ensino Fundamental Governador Leonel Brizola
}

Resumo: O objetivo deste artigo é destacar o expressivo desenvolvimento comportamental e atitudinal dos alunos dos 8ㅇs anos da Escola Municipal de Ensino Fundamental Governador Leonel Brizola, de tempo integral, a partir de experiências com saídas a campo, proporcionadas pela atuação do subprojeto interdisciplinar do Programa Institucional de Bolsas de Iniciação à Docência (Pibid), da Universidade de Caxias do Sul. Baseado nos aportes teóricos de Cavaliere (2002), Guimarães (2016), Leal (2010), Paro (1988), entre outros, o artigo aponta, por meio da metodologia narrativa e de reflexão, as atividades desenvolvidas pelos bolsistas na escola em questão, que proporcionaram resultados significativos referentes à apreensão cultural dos estudantes, suas aprendizagens em espaços além da sala de aula, além da melhoria nas relações com a comunidade escolar.

Palavras-chave: Ensino interdisciplinar. Pibid. Escola de tempo integral. Saída a campo.

\title{
Introdução
}

A preparação do corpo discente, docente e da comunidade em geral, para gerir as demandas sociais, políticas e econômicas, se dá para muito além das paredes da escola. A convivência em sociedade já propicia a formação do indivíduo como cidadão.

A escola é como um microssistema da sociedade, ela não apenas reflete as transformações atuais como também tem que lidar com as diferentes demandas do mundo globalizado. Uma de suas tarefas mais importantes, embora difícil de ser implementada, é preparar tanto alunos como professores e pais para viverem e superarem as dificuldades em um mundo de mudanças rápidas e de conflitos interpessoais, contribuindo para o processo de desenvolvimento do indivíduo. (DESSEN et al., 2007, p. 25).

A educação integral ocorre na sociedade, pois a criança não depende apenas do educador. (PARO, 1988, p. 27). Todavia, a vivência em comunidade

* Estudante do curso de Licenciatura em História; coordenadora do subprojeto interdisciplinar: Profa. Dra. Eliana Rela. Professor supervisor na Escola Governador Leonel Brizola: Márcio Rodrigues. 
perpetua conceitos deturpados de uma visão elitista de "cidadania", que baseiase, na contemporaneidade, como integração no mercado de trabalho e contribuição assídua e ativa para a economia do País. Esta realidade não alcança a todos. Assim, a função preparatória da escola deve ocorrer também nessa vivência, transmitindo a valorização do indivíduo como um todo.

A crítica à escola tradicional se desenvolveu tanto dentro de movimentos sociais populares como no liberalismo, mas foi através do lema "Educação integral para o homem integral" que chegou ao Brasil. (GALlo, 2002, p. 14). A ampliação da jornada escolar foi pensada no contexto da realidade educacional brasileira, por Anísio Teixeira e pelos pioneiros da Educação Nova em 1932, quando 26 educadores redigiram o documento "A reconstrução educacional no Brasil: ao povo e ao governo". Os educadores afirmavam que a escola tradicional deixava o indivíduo numa autonomia isolada e estéril; de tal forma, a Escola Nova objetivava ser pública, laica, obrigatória, gratuita, em tempo integral e que tivesse como preocupação a formação integral das pessoas para viverem na democracia, fortalecendo o integralismo no País. Segundo o redator do documento, é "[...] assentado o princípio do direito biológico de cada indivíduo à sua educação integral, e cabe evidentemente ao Estado a organização dos meios de o tornar efetivo". (AzEVEdo, 1932, p. 23).

Segundo o Documento Projeto Escola Pública Integrada,

no planejamento da matriz curricular para ampliação do tempo pedagógico é importante manter equilíbrio entre atividades de caráter mais lúdico e aquelas com características mais acadêmicas. O currículo em tempo integral deve prever espaços para realização das atividades relacionadas ao lazer, ao desenvolvimento artístico e cultural, ao esporte, ao acesso a novas tecnologias e a práticas de participação social e cidadã, como componentes essenciais à formação humana. (2003, p. 6).

Apesar das mudanças de conceito, de tempo, de espaço, de gestão e de aprendizagem que a escola de tempo integral sofreu ao longo da História, sempre se manteve a ideia de que a ampliação do tempo qualifica o processo de aprendizagem e diminui as desigualdades. A luta pela democratização da educação passa a ser priorizada pelo governo brasileiro em 2007, pela Portaria Interministerial n. 17 e, posteriormente, pelo Decreto Presidencial 7.083/2010, que instaurou o Programa Mais Educação. A partir deste, a Rede Municipal de 
Ensino (RME) torna-se prioridade para a implantação das Escolas de Tempo Integral.

A Escola Municipal de Ensino Fundamental Governador Leonel Brizola, objeto de estudo deste trabalho, é uma das quatro escolas de Ensino Fundamental, do Município de Caxias do Sul, Rio Grande do Sul, onde o conceito de Escola de Tempo Integral é aplicado - embora suas características fujam aos aspectos básicos do projeto-piloto do município, que pressupõe que a escola deve estar dentro dos limites da comunidade que a utiliza, e dispor de ambientes adequados para a permanência dos alunos por mais de sete horas por dia, como quadra poliesportiva, sala adequada para refeições, laboratório de informática e química, sala de artes, dentre outros.

O espaço cedido à escola é parte de um bloco localizado na Universidade de Caxias do Sul, bem distante do Loteamento Campos da Serra - local de origem dos alunos -, sem qualquer ambiente pensado para a permanência de alunos nas idades referentes ao Ensino Fundamental e, além disso, ainda é utilizado à noite por estudantes da Universidade, o que impossibilita a utilização específica dos espaços pelos alunos. Para Guimarães (2016, p. 20), “[...] diante disso, há uma indagação sobre o quanto esses alunos se sentem pertencentes de fato a essa escola, do quanto eles sentem, de fato, esse espaço físico como seu", e isso dificulta, ainda, a inserção da comunidade do Loteamento, no cotidiano escolar presença fundamental na construção da Escola Integral.

O subprojeto interdisciplinar do Programa Institucional de Bolsas de Iniciação à Docência (Pibid), da Universidade de Caxias do Sul, passou atuar na Escola Governador Leonel Brizola, sob coordenação da Profa Dra. Eliana Rela ${ }^{1} \mathrm{e}$ supervisão do professor de História e Geografia, Márcio Rodrigues, a partir de agosto de 2016, tendo em vista a necessidade de acompanhamento lúdico e interdisciplinar da escola como um todo. No início de 2017, o Grupo Interdisciplinar passou a contar com cinco bolsistas: Andressa Bernardi de Jesus, Lucas Sobroza, Natalia Ferreira, Steffany Cardoso e a pesquisadora.

\footnotetext{
${ }^{1}$ Doutora em Informática na Educação, pela Universidade Federal do Rio Grande do Sul (UFRGS) e graduada em História. Docente permanente no Programa de Pós-Graduação em História da Universidade de Caxias do Sul.
} 


\section{Referencial teórico}

Cavaliere (2002) traz abordagens críticas quanto à eficácia da Escola de Tempo Integral, afirmando que a ideia traz inovações positivas para a rede de ensino pública, mas que ela raramente é empregada de forma adequada perante a realidade educacional brasileira. As escolas, desde uma perspectiva macro, até as particularidades de cada realidade socio-econômica, enfrentam dificuldades na aplicação da metodologia de ensino integral, que vão desde a ausência de uma estrutura adequada para a implementação, até a pouca capacitação para os profissionais que atuariam como mediadores do conhecimento nessa perspectiva inovadora. Isso interfere na vida dos estudantes; por isso, tem extrema necessidade a discussão sobre esta metodologia, dentro de todos os segmentos da comunidade escolar.

Complementando a abordagem anterior, Guimarães (2016) questiona a permanência dos alunos nas escolas de tempo integral e a estreita relação que há na proximidade da Escola com a comunidade de origem dos alunos que a frequentam. A escola de tempo integral precisa estruturar-se nos padrões da realidade de sua demanda de estudantes; caso contrário, apenas acrescenta horas no ano letivo dos estudantes, não fazendo diferença na forma como ela vai exercer seu papel social na comunidade em que se insere - ou deveria estar inserida. No caso abordado pela autora, a escola sequer encontra-se nos limites da comunidade de origem dos alunos, o que dificulta ainda mais a apreensão do papel mediador dentro da realidade social.

Paro (1988) mobiliza a discussão sobre metodologias inovadoras, que podem auxiliar na superação da já descrita dificuldade de adequação da escola de tempo integral, na rede pública de ensino. Esta discussão é pautada na implementação de saídas a campo para todas as áreas do conhecimento, possibilitando a integração da teoria vista em sala de aula e a prática, para além do quadro negro. As saídas devem, contudo, adequar-se à realidade do aluno, sempre visando a maior apreensão possível do conteúdo previsto pelo professor mediador e o papel social que ele desempenha.

Seguindo a linha proposta por Paro, Leal (2010) reflete sobre o papel das saídas a campo, como metodologia inovadora na prática docente dentro da Geografia e da História. Dentro da área das humanidades, as saídas possibilitam 
maior integração do conteúdo com a realidade, uma vez que o seu objeto de estudo trata-se do ser humano e de suas relações com o ambiente em que vive, através do tempo. Além do conteúdo visto em sala de aula, a vivência no campo de estudo possibilita ao aluno uma nova visão sobre sua realidade e seu papel na transformação da sociedade como um todo.

\section{Período de realização}

O período de realização das atividades descritas iniciou em 31 de agosto de 2016, com a primeira saída a campo mediada pelo Subprojeto Interdisciplinar, e termina na última saída a campo, ocorrida no dia 5 de outubro de 2017. 0 período de atividades compreende não somente as saídas a campo, mas o trabalho semanal realizado pelos bolsistas com os alunos dos $8^{\text {os }}$ anos A e B.

\section{Metodologia}

A busca por métodos de ensino eficazes e adequados é discutida nos Parâmetros Curriculares Nacionais, os quais estimulam a busca de atividades diferenciadas e inovadoras que possam explorar o ambiente de aprendizagem, por meio de uma abordagem multidisciplinar. (BRASIL, 1998, p. 79). Desde o início da atuação do subprojeto interdisciplinar do Pibid-UCS, na Governador Leonel Brizola, através do acompanhamento intrínseco nas aulas do professor de História e Geografia do turno da tarde, especificamente mediadas para os $8^{\text {os }}$ anos $A$ e $B$, uma série de inovações metodológicas no andamento do período letivo foram proporcionadas, desde aulas com ferramentas digitais, oficinas e saídas a campo - dessas, as saídas a campo foram as que mais evidenciaram uma efetiva mudança comportamental dentro e fora da sala de aula.

A saída a campo, quando tida como atividade complementar para o conteúdo visto dentro de sala de aula, favorece a interdisciplinaridade, ao proporcionar ao aluno um ambiente pragmático de ensino e aprendizagem. Ela "permite aos estudantes o conhecimento do modo de vida e da cultura dos diferentes espaços que fazem parte da comunidade, sendo uma atividade importante para uma metodologia de ensino que favoreça o desenvolvimento integral do indivíduo". (RonCATo, 2015, p. 3). 
Nas disciplinas de História e Geografia, as saídas a campo desempenham papel ainda mais decisivo para a apreensão da teoria, pois os alunos põem em prática, no ambiente de estudo, o resultado da reflexão sobre o papel do homem na transformação do ambiente e das relações humanas, ao longo do tempo. (LEAL, 2010, p. 14).

A primeira saída a campo se deu no dia 31 de agosto de 2016, por meio da ida ao Lepar-UCS (Laboratório de Pesquisas Arqueológicas da Universidade de Caxias do Sul), que situa-se próximo ao bloco cedido à escola. Os alunos foram a pé. A oficina ocorreu nos parâmetros teórico-práticos, isto é, com uma breve apresentação do trabalho do arqueólogo - desde suas funções até os objetos utilizados em uma escavação - por uma mediadora que acompanhou os alunos para o segundo momento da visitação; a prática, por sua vez, se deu através de uma escavação simulada, em que os alunos receberam os materiais necessários para escavarem em uma pequena área com objetos escondidos, e, após isto, catalogar os que tivessem encontrado. O comportamento dos alunos, ao identificarem as peculiaridades que caracterizam a natureza e utilização de um artefato evidenciou empenho ao pôr em prática o que foi instruído na fala inicial da mediadora. Na volta, todavia, também a pé, alguns alunos se dispersaram e chegaram atrasados na escola.

Embora o resultado não tenha sido satisfatório em uma primeira saída a campo, o grupo de bolsistas não deixou de apostar na melhoria da postura dos alunos, e continuou a possibilitar saídas a campo, após a reflexão sobre o que poderia ser feito para proporcionar uma experiência positiva.

Segundo o relato, ${ }^{2}$ no blog do Subprojeto Interdisciplinar Pibid-UCS (20162017), na segunda saída a campo, ocorrida no dia 17 de maio de 2017, as turmas do 8 o ano foram levadas ao Museu da Força Expedicionária Brasileira. A estrutura da visita foi alterada para introduzir conceitos trabalhados pelo período de guerras.

[...] foram usadas 15 imagens, sendo 3 panfletos e 12 fotografias de diversos contextos: juventude hitlerista, fascistas em Caxias do Sul, meninas da metalúrgica Gazola, o monumento às que foram mortas na explosão, um menino sendo condecorado pelo Ministro da Propaganda Joseph Goebbels,

\footnotetext{
${ }^{2}$ Feito pela bolsista Natália Ferreira, do subprojeto interdisciplinar da Escola Governador Leonel Brizola, que também mediou a visita ao Museu da Força Expedicionária Brasileira.
} 
um panfleto alemão incentivando brasileiros à deserção, um panfleto brasileiro incentivando alemães à rendição incondicional da tropa, outro panfleto brasileiro argumentando quanto à participação da FEB na Guerra, um grupo de civis italianos partigiani muito bem armados, uma mulher partigiani com uma arma, pilhas de corpos do extermínio dos campos diante de americanos, e uma "sombra nuclear". Além destas imagens, foram utilizadas fotos do acervo da exposição "Nossos Pracinhas na Segunda Guerra Mundial", como buracos da artilharia, uma peça de canhão, os alemães rendidos, o acampamento provisório, o sargento Max Wolff Filho, um soldado ferido sendo medicado, a FAB, dentre outras. (Blog Pibid-UCS, 2016).

As imagens servem para exemplificar alguns fatos e também despertar problematizações e curiosidades, além de chocar os alunos. As imagens utilizadas durante a visita surtiram efeito ao despertar observações interessantes aos alunos, diferentemente do que teria acontecido, se elas fossem apresentadas em sala de aula, sem a ambientação para isso. O ensino se torna mais abrangente quando utiliza representações visuais, pois elas permitem a aprendizagem de tudo o que os textos escritos não conseguem revelar. (EISNER, 2008, p. 10).

$\mathrm{Na}$ terceira visita, os alunos demonstraram maturidade, prestaram atenção no que foi dito, contribuíram para o bom andamento da visita, interessaram-se, fizeram perguntas e participaram ao visitarem o Memorial da Marcopolo (empresa transnacional brasileira fabricante de carrocerias de ônibus, com sede em Caxias do Sul) e a Escola de Fábrica (parte da empresa voltada para o aperfeiçoamento profissional de aprendizes).

Segundo o relato, ${ }^{3}$

[...] a monitora contou a história de um dos fundadores, senhor Valter Gomes Pinto, que dá nome ao Memorial, a história da empresa, seguida de um vídeo de alguns funcionários e alguns depoimentos escritos. Depois destes momentos, foi a hora de entrar no ônibus Nicola, modelo antigo produzido pela empresa, que gerou animação e curiosidade nos alunos. 0 professor que os acompanhou para a visita na Escola da Fábrica relatou sua experiência de Marcopolo e levou-os ao passeio pela escola. Os alunos se mostraram particularmente interessados neste momento, tiraram fotos e fizeram comentários. Ao final da visita, receberam um jornal comemorativo e um Paper Toy do ônibus Nicola. Houve muitos comentários posteriores demonstrando interesse em participar da escola da empresa. (Blog PibidUCS, 2017).

3 Feito pela bolsista Andressa Bernardi de Jesus, do subprojeto interdisciplinar da Escola Governador Leonel Brizola, que estava presente na saída a campo descrita. 
Na visita ao Instituto Hércules Galló (complexo de edificações históricas que remetem à industrialização da região de Caxias do Sul) e à vila operária, em Galópolis, quarta saída a campo dos alunos, ocorrida no dia 29 de agosto de 2017, os alunos aproveitaram a visitação, mantiveram-se atentos durante as explicações sobre a imigração italiana, a vinda do empreendedor Hércules Galló e a indústria caxiense na sua primeira fase de adaptação, questionando acerca do conteúdo apresentado e os espaços que integram o instituto e a vila. Ateramse, principalmente, nos espaços peculiares da segunda residência pertencente a Galló, como o porão e o sótão, além das peças do acervo pessoal da família que lá morou até a segunda metade do século $X X$, expostos nas diversas salas que compõem a residência. Já na vila operária, que circunda o espaço que hoje compreende a praça do bairro, dispersaram-se, mas retornaram ao transporte que os levaria de volta à escola no horário estipulado. Tiraram várias fotos, tanto para mostrar aos colegas, professores e familiares como para utilizá-las no posterior trabalho com diários de campo. O retorno à escola e os dias que se seguiram foram marcados por discursos vindos dos próprios alunos para professores e a coordenação pedagógica sobre como foi a visitação e o que lá foi aprendido, todos ilustrados com diversas fotos.

Na última saída a campo, ocorrida no dia 5 de outubro de 2017, os alunos visitaram a Feira do Livro de Caxias do Sul, evento anual que reúne leitores e autores em um mesmo espaço. Os alunos leram, previamente, o livro Meu avô tem oito anos de Sônia Travassos, autora carioca que os recebeu para uma sessão de debates sobre o livro e sua temática. Segundo o relato, ${ }^{4}$

\begin{abstract}
apesar do atraso em virtude do transporte, os estudantes chegaram animados, demonstraram interesse na fala da autora e entusiasmo principalmente no momento em que se viram nas fotos e vídeos que foram passados no telão do teatro. Ficaram tímidos para fazer as perguntas que haviam elaborado em aula, mas a atividade bem como a saída a campo foram enriquecedoras; ao final da conversa com a autora, a escola se dispersou pela Feira do Livro sem organização prévia, mas mesmo assim reuniram-se no local combinado e voltaram à escola com segurança. (Blog Pibid-UCS, 2017).
\end{abstract}

\footnotetext{
${ }^{4}$ Feito pela bolsista Natália Ferreira, do subprojeto interdisciplinar da Escola Governador Leonel Brizola, que estava presente na saída a campo na Feira do Livro.
} 


\section{Conclusão}

Uma Escola de Tempo Integral deve transformar o padrão tradicional da realidade educacional brasileira, criando uma perspectiva de emancipação para seus alunos que, em sua maioria, encontram-se nas periferias, justamente onde a Rede Municipal de Ensino atua. Todavia, conforme estudo acerca da Escola Municipal de Ensino Fundamental Governador Leonel Brizola, nota-se que a única modificação efetiva, para transformá-la em um ambiente de Ensino Integral vem por parte da direção, dos professores e funcionários -, não dos órgãos que propuseram o projeto de Escolas de Tempo Integral.

A participação ativa do Subprojeto Interdisciplinar do Programa Institucional de Bolsas de Iniciação à Docência (Pibid), nas aulas de Geografia e História, mediadas às turmas do $8^{\circ}$, além das oficinas ministradas a todos os alunos da escola e, em especial, as saídas a campo, conforme um estudo dirigido organizado e aplicado pela pesquisadora, foram alternativas que surtiram efeito para a construção de um ambiente escolar adequado para o corpo discente e um ambiente de trabalho agradável para os membros docentes e funcionários.

Conforme levantamento feito pela pesquisadora, cerca de $86 \%$ dos professores e funcionários da Escola Governador Leonel Brizola, entrevistados, notaram melhora significativa após as atividades propostas pelo subprojeto interdisciplinar Pibid-UCS, assegurando que esta melhora ultrapassa a sala de aula, atingindo desde o relacionamento entre colegas, profissionais, até mudanças na comunidade onde vivem. O levantamento evidenciou ainda que cerca de $74 \%$ dos alunos entrevistados também notaram melhoras comportamentais nos colegas e em si mesmos, afirmando que as oficinas e saídas a campo desempenharam papel determinante para a construção de uma Escola de Tempo Integral mais íntegra, agradável e condizente com suas premissas.

Embora eu participe do subprojeto há menos de um ano, posso afirmar que minha futura atuação docente será efetiva devido às experiências tidas durante minha permanência no Pibid-UCS. A valorização da relação entre professor-aluno e demais profissionais da escola, a adaptação de metodologias inovadoras na realidade educacional, a abrangência de características específicas da comunidade e, em suma, a postura do professor, como determinante para a 
formação de indivíduos emancipados e íntegros, capazes de transformarem o meio em que vivem, são perspectivas adquiridas por meio da atuação docente na Escola Governador Leonel Brizola, que irão traçar o perfil profissional que pretendo seguir.

\section{Referências}

AZEVEDO, Fernando et al. Manifesto dos pioneiros da educação nova: a reconstrução educacional no Brasil: ao povo e ao governo. Rio de Janeiro: [...], 1932. Disponível em: <http://www.pedagogiaemfoco.pro.br/heb07a.htm>. Acesso em: 10 nov. 2017.

BRASIL. Secretaria de Estado da Educação. Documento Projeto Escola Pública Integrada - EPI. Brasília: SED, 2003.

BRASIL. Secretaria de Educação Fundamental. Parâmetros Curriculares Nacionais: terceiro e quarto ciclos do Ensino Fundamental - temas transversais. Brasília: MEC/SEF, 1998.

CAVALIERE, Ana Maria Villela. Escolas de tempo integral: uma ideia forte, uma experiência frágil. In: CAVALIERE, Ana Maria Villela; COELHO, Lígia Martha Coimbra da Costa (Org.). Educação brasileira e(m) tempo integral. Petrópolis, RJ: Vozes, 2002.

CAXIAS DO SUL. Plano municipal de educação. Lei Municipal 7.448, de 22 de maio de 2012. Disponível em: <http://www.caxias.rs.gov.br/smed/portaldaeducação>. Acesso em: 10 nov. 2017.

CAXIAS DO SUL. Parecer CME 030, de 12 de agosto de 2014. Disponível em: <https://www.caxias.rs.gov.br/_uploads/conselho_educacao/639/030-Politica-EdIntegral-em-Tempolntegral-limpo>. Acesso em: 10 nov. 2017.

CONSELHO NACIONAL DE EDUCAÇÃO. Câmara de Educação Básica. Diretrizes Curriculares Nacionais para o Ensino Fundamental - Resolução 07/2010: Disponível em: <http://www.mec.gov.br/>. Acesso em: 11 nov. 2017.

DESSEN, Maria Auxiliadora et al. A família e a escola como contextos de desenvolvimento humano. Paidéia, v. 17, n. 36, 21-32, 2007. Disponível em: <http://www.scielo.br/pdf/paideia/v17n36/v17n36a03>. Acesso em: 11 nov. 2017.

EISNER, Elliot W. O que pode a educação aprender das artes sobre a prática da educação? Currículo sem Fronteiras, v. 8, n. 2, p. 5-17, jul./dez. 2008. Disponível em: $<$ http://www.curriculosemfronteiras.org/vol8iss2articles/eisner.pdf >. Acesso em: 12 nov. 2017. 
GALLO, Silvio. A educação integral numa perspectiva anarquista. In: COELHO, Lígia Martha Coimbra da Costa; CAVALIERE, Ana Maria Villela (Org.). Educação brasileira e(m) tempo integral. Petrópolis, RJ: Vozes, 2002. p. 13-42.

GUIMARÃES, Carmem Nunes. A escola como espaço coletivo: implicações na construção da identidade dos jovens como sujeitos sociais. 2016. Monografia (Especialização em Coordenação Pedagógica) - UFRGS, Porto Alegre, 2016.

LEAL, Daniela Filipa Ruas. As saídas de estudo na aprendizagem da Geografia e da História. 2010. Dissertação (Mestrado em Ensino de História e Geografia no 3 Ciclo do Ensino Básico e Ensino Secundário) - Universidade de Porto, Porto, 2010.

PARO, Vitor Henrique et al. Escola de tempo integral: desafio para o ensino público. São Paulo: Cortez. Autores Associados, 1988.

PIBID-UCS. Subprojeto Interdisciplinar Escola Leonel Brizola: relatos. Ago. 2016. Disponível em: <https://pibid-ucs-interdisciplinar.blogspot.com.br/p/leonel-brizola .html>. Acesso em: 12 nov. 2017.

RONCATO, Karine. As saídas a campo realizadas em aulas do ensino regular como uma possibilidade para o desenvolvimento de uma educação integral. 2015. Monografia (Especialização em Educação Integral) - UFRGS, Porto Alegre, 2015. 
14

TEMÁTICAS E DILEMAS ÉTICOS DO LÚDICO: O DESAFIO DO ENSINO DE ÉTICA NAS ESCOLAS A PARTIR DE UMA EXPERIÊNCIA DO PIBID/UCS DE FILOSOFIA

\author{
Dr. Luis Fernando Biasoli* \\ luisbiasoli@hotmail.com \\ Coordenador do subprojeto Filosofia
}

\title{
1 Dilemas da reflexão ética na escola
}

A ética é uma ciência com 2500 anos de história e, ainda, apresenta muitos desafios para ser ensinada sistematicamente, refletida criticamente e debatida seriamente no Ensino Médio. Geralmente, os alunos não veem a reflexão ética como uma ferramenta intelectual, que pode transformar a vida das pessoas em sociedade, possibilitando uma convivência justa e harmônica, criando um espaço de responsabilidade ${ }^{1}$ e solidariedade. É notório que nosso tempo vive uma acentuada crise ético-moral, com profundas implicações para todos, como também uma grave e profunda descrença nos princípios éticos assumidos e vivenciados pelos jovens.

Diante disso, a escola não pode ficar indiferente a essa preocupação crescente gerada pela crise ética, pois, de certa forma, ela também é afetada por esse caldo de cultura do relativismo ético-moral. Como uma instituição muito importante na formação das pessoas e, sobretudo, por trabalhar com jovens e adolescentes, a escola tem um enorme potencial, para apontar caminhos que ajudem na construção de uma sociedade pautada com mais valores éticos. Como já dissera Kant, "o homem não pode se tornar homem a não ser pela educação". (KANT, 1989, p. 73).

Os estudantes das escolas, ainda, não estão familiarizados com a leitura de textos clássicos e consagrados da tradição filosófica. O objetivo deste trabalho é analisar métodos alternativos de ensino da ética, que consigam aliar o rigor

\footnotetext{
* Professor de Filosofia na Universidade de Caxias do Sul.

${ }^{1}$ A responsabilidade é um tema muito estudado nas correntes éticas hodiernas. Para uma análise da importância da responsabilidade das ações de hoje, da atual civilização tecnológica e seu impacto para a preservação do meio ambiente, para que gerações seguintes tenham as condições de poderem desenvolver sua vida, ver a proposta de Hans Jonas, na obra, $\mathbf{O}$ princípio da responsabilidade: ensaio de uma ética para a civilização tecnológica.
} 
científico dos conceitos da tradição filosófica com a ludicidade e interatividade dos jovens do século XXI. Para isso, testou-se o desenvolvimento de um jogo que focasse na resolução de dilemas e desafios éticos, sua grande preocupação primordial. O Role Playing Game (RPG) é um jogo que simula a sociedade clássica grega onde os alunos devem ser motivados a conhecer, previamente, a situação política e os condicionantes histórico-sociais, a fim de poderem tirar o máximo proveito da atividade.

Para mostrar como o jogo Role Playing Game (RPG) pode ser uma ótima alternativa didático-pedagógica, para o despertar da reflexão ético-crítica dos alunos, primeiramente far-se-á uma análise conceitual do termo ética, remontando da Grécia antiga até nossos dias, passando pelos principais pensadores que deixaram marcas nessa ciência e, ainda, são objetos de grandes estudos. Depois, mostrar-se-á como foi pensado e estruturado o jogo de RPG, que tenta resgatar para os jovens estudantes a curiosidade e gosto pela reflexão sobre ética e, também, mostrar-se-á como ele foi aplicado em sala de aula. Como conclusão, analisar-se-ão avanços conseguidos por meio dessa forma de tratar e estudar os dilemas éticos.

É fundamental que as aulas de ética, ou quando temas éticos são tratados nas aulas de filosofia ou de ciências humanas, sejam ministradas com a adequada preparação e o suporte pedagógico e que sejam atraentes e cativantes para os alunos, despertando nos educandos o gosto pela leitura e gerando estímulos para novas reflexões. Outro aspecto a ser abordado é mostrar quanto a ética é fundamental na formação da cidadania, projetando-se uma reflexão sobre alguns dos caminhos que a Constituição denominada de cidadã de 1988 abriu e fundamentou para o ensino dos princípios, que devem nortear o relacionamento entre as pessoas e seu impacto na educação.

A superação do vazio de referenciais ético-morais, por meio da apresentação crítico-sistemática de modelos de vida ética, ao longo da tradição filosófica, fundamentadas na riqueza do pensamento da história da ética, parece ser um caminho que as escolas podem trilhar, a fim de preencher essa lacuna que deixa os estudantes frágeis e desestimulados, para poderem vencer os desafios do futuro. Este estudo e a reflexão serão conduzidos por meio de análises e reflexões de dilemas éticos. 
Os dilemas morais ajudam a tornar o estudo mais cativante, pois as respostas não são prontas e estão sempre provocando novas interrogações. Exemplificando: é possível justificar, eticamente, a morte de uma pessoa para salvar cinco? Um empresário à beira da falência de seu negócio, o que ocasionará a demissão de seus empregados, pode legitimamente não pagar os impostos, para tentar salvar a empresa? As provocações são fortes e há milênios interpelam o homem sobre qual a coisa correta a se fazer. Quando os alunos são postos nesse debate e percebem que é um problema que thes diz significativamente, eles interagem e participam de uma maneira muito inteligente e criativa.

O estudo das questões de ética tem uma importância muito grande para a formação cidadã dos jovens e adolescentes, e a fase escolar pode acrescentar grandes contribuições para o desenvolvimento e a formação de pessoas que consigam dar respostas condizentes com os desafios éticos de uma sociedade, cada vez mais pluralista e que busca a justiça social e a participação. Para atingir os objetivos de mostrar como o estudo, o ensino e a reflexão sobre dilemas éticos têm imensa relevância em nosso tempo, deve-se conceituar o que vem a ser ética. Segundo Abbagnano,

\footnotetext{
existem duas concepções fundamentais dessa ciência: 1a a que considera como ciência do fim para o qual a conduta dos homens deve ser orientada e dos meios para atingir tal fim, deduzindo tanto o fim quanto os meios da natureza do homem; 2a a que a considera como a ciência do móvel da conduta humana e procura determinar tal móvel com vistas a dirigir ou disciplinar essa conduta. (2003, p. 380).
}

Qual a conduta certa a se fazer ou quais são os meios que devem ou podem ser usados, para atingir o objetivo da ação humana estão no centro das preocupações. $O$ debate entre o certo e o errado no campo da filosofia prática aparece bem cedo para os alunos que se veem inseridos num mundo de muitas informações e possibilidades de agir. Assim, um estudo sistemático e organizado dos grandes temas da história da ética ajuda a fornecer subsídios, a fim de que 
os alunos compreendam que a ação humana deve estar fundamenta em princípios e valores ${ }^{2}$ perenes.

Em épocas de grande relativismo moral, como o nosso, há, também, a dificuldade de mostrar e convencer os alunos que os limites ou as normas éticas não são algo que vai contra a natureza humana ou que serve para tolher as potencialidades e criar impedimentos à realização pessoal, mas, justamente ao contrário, os valores e os princípios advindos de uma reflexão ética é que, verdadeiramente, tornam o ser humano mais pleno e realizado, ou seja, uma vida que vale, realmente, ser vivida. ${ }^{3}$

Pode-se dizer que a existência humana só é completa, quando vivida dentro de um espaço ético no qual todas as pessoas podem desenvolver suas habilidades e seus conhecimentos advindos de uma configuração social, na qual todos tenham oportunidades de aprendizagem e emprego.

O pensamento e a reflexão ética não são uma invenção dos modernos, mas um legado que remonta da Grécia antiga, quando o homem tomou consciência de que ele é a grande pergunta que deveria ser respondida, ou seja, ao mesmo tempo em que busca compreender as coisas do mundo natural deve, sobremaneira, se preocupar consigo mesmo e com o seu relacionamento com as outras pessoas. Diga-se, de passagem, que o debate ético encontrou condições para florescer, devido ao espírito democrático que a cidade grega estava vivendo, onde as pessoas podiam expressar suas opiniões livremente. Segundo Mondolfo,

o predomínio do problema antropológico surge em consequência do crescente desenvolvimento democrático das cidades gregas das guerras persas. Com a intervenção de novas e mais amplas classes no governo do Estado e com a crescente importância das assembleias e dos tribunais, as discussões jurídicas e morais tomam uma difusão e desenvolvimento que devem ter em conta os novos mestres da cultura, [...] dessa forma o aparecimento dos sofistas, mestre errantes, e o caráter humano e político dos problemas tratados preferentemente por eles, e também o fato de

\footnotetext{
2 Segundo Abbagnano, o valor em termos filosóficos começa, quando seu significado é generalizado, para indicar qualquer objeto de preferência ou de escolha, o que acontece pela primeira vez com os pensadores estoicos que colocaram o termo no domínio da ética e denominaram de valores os objetos de escolha moral. (2003, p. 989).

3 Segundo Aristóteles, "considera-se que toda arte, toda investigação e igualmente todo o empreendimento e projeto previamente deliberado colimam algum bem, pelo que se tem dito, com razão, ser o bem a finalidade de todas as coisas". (2009, p. 37).
} 
Sócrates e a maior parte dos seus discípulos permanecerem no mesmo terreno do humanismo. (1971, p. 135).

O nascimento da própria ética, enquanto disciplina, ocorreu junto com as discussões públicas sobre os temas mais candentes e que, grandemente, afligiam e angustiavam a sociedade que buscava soluções políticas e sociais, para uma melhor qualidade de vida para todos. Os temas tratados pela ética têm um grande apelo entre os jovens e adolescentes que estão numa fase de descobrir coisas novas na vida e a um passo de serem adultos com as responsabilidades e os desafios que lhes são inerentes. Diante da importância da ética, pode-se perguntar: Como o ensino de ética nas escolas está inserido e contextualizado dentro do panorama atual da educação brasileira?

\section{O ensino de ética na escola brasileira}

Cada vez mais cresce a consciência entre educadores e os definidores de políticas educacionais de que o ensino de ética é imprescindível e fundamental para a formação integral do aluno. A partir disso, pode-se afirmar que a ética vem ganhando espaço nas salas de aula, com avanços significativos nas últimas décadas. Contudo, desafios ainda precisam ser superados. A reflexão ética trabalha com argumentos e palavras e exige que o aluno estruture seu pensamento com argumentos lógicos e domínio da linguagem.

A palavra e o debate de ideias são vitais para o amadurecimento ético do ser humano, assim, desde cedo, deve-se propiciar aos jovens a possibilidade de um estudo dialógico da reflexão ético-moral. Diferentemente das ciências exatas, o processo pedagógico da ética acontece num espaço de construção permanente, onde todos os envolvidos têm experiências de vida a contribuir e uma variada riqueza de perspectivas a trazer para a discussão. Sem esse intercâmbio de ideias, com a partilha de visões de mundo, fica mais difícil chegar-se a um juízo ético justificado.

No Brasil, cresce, cada vez mais, a preocupação da sociedade civil e dos agentes públicos em potencializar a escola como meio de formação integral dos alunos, por meio da reflexão de problemas éticos em sala de aula, apesar de essa diretriz, ainda, não ser uma unanimidade, e, por vezes, encontrar objeções e desconfianças em certos setores ainda não bem convencidos da necessidade de formação de uma educação cidadã. 
Porém, o fato de, historicamente, verificar-se a presença da preocupação com a formação moral do aluno ainda não é argumento bastante forte. De fato, alguns poderão pensar que a escola, por várias razões, nunca será capaz de dar uma formação moral aceitável e, portanto, deve abster-se se dessa empreitada. Outros poderão responder que o objetivo da escola é o de ensinar conhecimentos acumulados pela humanidade e não preocuparse com uma formação mais ampla de seus alunos. (BRASIL, 1997b, p. 51).

Mas, há de se reconhecer que, apesar das reticências e oposições, a ética ganha espaço e aceitação por parte de pais, alunos e professores, dado o pano de fundo da crise de valores da sociedade, quando vislumbra-se, no estudo da ética, uma chave para a superação das dicotomias profundas de nossa sociedade. O Brasil, à luz das leis que regem a nação, tem condições de apresentar avanços no ensino e na reflexão sobre ética, que deve começar, sobremaneira, na sala de aula.

A superação das contradições e das divergências é um exercício muito positivo, pois permite que os jovens e adolescentes percebam que a ética não é uma ciência pronta ou acabada, semelhante a um código religioso ou um dogma, mas que a todo momento deve ser confrontada a dar as razões de sua escolha ou que justifiquem uma atitude tomada em detrimento da outra. A Carta Magna de 1988 expressou, como direitos do povo brasileiro, a liberdade e o pluralismo de pensamento e que deve, também, estar presente na sala de aula.

A Constituição da República Federativa do Brasil promulgada em 1988, pela primeira vez na história, inicia a explicitação dos fundamentos do Estado brasileiro elencando os direitos civis, políticos e sociais dos cidadãos. Também coloca claramente que os três poderes constituídos, o Poder Executivo, o Poder Legislativo e o Poder Judiciário, são meios - e não fins - que existem para garantir os direitos sociais e individuais. Os fundamentos do Estado Democrático de Direito são: a soberania, a cidadania, a dignidade da pessoa humana, os valores sociais do trabalho e da livre iniciativa, o pluralismo político (art. 10 da Constituição Federal). (BRASIL, 1997a, p. 19).

A pluralidade de opiniões precisa ser provocada por temas e dilemas que instiguem os alunos a saírem de suas concepções ético-morais, por vezes, fundamentas em prejuízos e preconceitos e moldadas pelo senso comum ou pela superficialidade da mídia e das redes sociais e, ao mesmo tempo, os despertem para o gosto da leitura e do debate, como meio de crescimento da consciência especulativa e crítica. 
O debate sobre ética necessita estar presente no cotidiano das pessoas e quando mais cedo se desperta nas pessoas o gosto pela aprendizagem sobre ética melhores serão os resultados na formação especulativa e com consequências práticas positivas para todo o tecido social.

Sabe-se que o debate sobre questões de ética e, consequentemente, sobre cidadania é, ainda, muito frágil na cultura brasileira. Não há o hábito de se olhar a realidade além do véu do senso comum em questões éticas, o que acaba gerando ações e práticas que vão fragilizando a convivência em sociedade no Brasil. Como sintoma disso, percebe-se o aumento alarmante da violência, as manifestações de racismo e a indiferença diante da gritante injustiça social. Para superar essas dificuldades, precisa-se formar cidadãos mais conscientes de seu potencial, para transformar essa realidade; pois é inconcebível que a escola não seja um espaço onde não se debate com responsabilidade e espírito reflexivo essas questões.

Sem uma dimensão dialética do conhecimento, ou seja, através de meios que estimulem o debate inteligente, respeitoso e saudável, será difícil criar as condições de uma sociedade que preze pela defesa da justiça e do respeito ao diferente. Como a educação e o ensinar em sala de aula têm muitos desafios, pergunta-se: Quais seriam as possíveis alternativas e os meios pedagógicos, para tornar uma aula de ética em espaço educativo que retenha a atenção dos alunos? O que é o RPG (Role Playing Game) e como ele pode ser utilizado em sala de aula para o debate de dilemas éticos?

\section{Debater ética na sala de aula através de jogos}

O RPG é um jogo muito utilizado pelos jovens, como meio de diversão e foi adaptado para o ensino de ética, que consiste no recorte e no estudo de uma cena de uma determinada época histórica marcante. A partir disso, cada aluno ou grupo de alunos assume um determinado papel de um personagem ilustrativo do contexto histórico e social do qual se está estudando e problematizando.

Os alunos são convidados a interpretar determinados personagens históricos, assumindo seus modos de pensamento e sua visão de mundo. Ou seja, pensar e agir como determinada figura daquele período histórico. Para isso, 
requer-se que eles leiam e estudem, previamente, os personagens que irão interpretar. Portanto, o RPG estimula que todos analisem e pesquisem sobre as características marcantes dos personagens. Quanto mais informações tiverem sobre a cultura, forma de vida, hábitos; melhores serão as possibilidades de darem respostas pertinentes e adequadas às situações, quando demandados.

O jogo em tela, passa-se na pólis grega em 399 a.C., onde cinco personagens estão partindo de Atenas ruma a Delfos, a cidade do oráculo, e no trajeto se deparam com diferentes dilemas éticos como: Dar ou não esmolas?, a mitologia tem validade para explicar o mundo e os questionamentos sobre o papel da mulher na sociedade, entre outras questões sociais e, éticas que vão emergindo no trajeto. Ou seja, esses dilemas éticos tratavam de questões atinentes ao mundo político helênico do IV e V séculos a. C.

Para o desenvolvimento do jogo, alguns alunos assumiram o papel do filósofo Sócrates, que tinha uma visão ética de que o mal era fruto da ignorância das pessoas; outros interpretavam Solênides, um nobre que, após a morte da mãe, viu sua família cair na miséria, devido à má administração das riquezas pelo pai. Esse, ao perder a mulher, caiu em "vícios excessivamente dionisíacos", como afirmava, aos quatro ventos, o próprio Solênides.

Neomides, por sua vez, é um jovem de 22 anos, nascido em Atenas, tinha a oportunidade de estudar nas melhores escolas da cidade e ter uma educação com qualidade superior. É dono de uma grande quantidade de terras em Atenas e em seus arredores e cultiva azeitonas. Portanto, é um homem livre, filho de atenienses e rico proprietário de terras, ou seja, um cidadão ateniense, podendo gozar de todos os direitos da incipiente democracia, e tem vez e voz nos grandes debates políticos na ágora (praça pública). Tem-se, ainda, Dione que é uma forte mulher espartana de 33 anos com grande habilidade na arte do arco e flecha, de porte atlético deixa seu filho de três anos sob os cuidados de sua irmã e com grande esperança parte em busca de respostas no Oráculo de Delfos, e, por fim, Díomedes, o escravo.

Os alunos assumem a figura de um personagem do jogo, por meio de um sorteio prévio. Depois dessa etapa inicial, definidos os papéis representativos de cada grupo de alunos, eram lançadas perguntas e cada grupo ou aluno deveria responder de acordo com o pensamento e o papel social e filosófico do personagem que lhe foi designado por sorteio. Os personagens estavam indo a 
Delfos, local de grande tradição e influência na sociedade grega, e eles deveriam passar por vários obstáculos e lugares, para chegar ao seu local de destino.

Em cada parada do trajeto, havia uma situação que propiciava um debate sobre um dilema ético, no qual os personagens eram confrontados, e os alunos, então, deveriam responder e refletir sobre esses questionamentos da temática ética, a partir da perspectiva de seu personagem. As respostas eram avaliadas pelo professor que dava uma nota pelo desempenho argumentativo. A nota obtida era um critério para se passar à etapa seguinte rumo a Delfos. No final, todos chegam a Delfos, uns com mais facilidades e melhor desempenho no percurso, mas todos desafiados a pensar e a refletir sobre os rumos da reflexão ética em nossa sociedade e os desafiados a se somarem na construção de uma sociedade melhor para todos.

\section{Notas conclusivas}

A reflexão sobre problemas de ética em sala de aula, por meio de uma atividade ou jogo como o RPG, como viu-se no trabalho, apresentou aspectos muito positivos que merecem ser destacados e tornados públicos, para que, cada vez mais, os educadores tenham acesso a matérias e subsídios diferenciados e inovadores, que thes forneçam meios de fazer com que o estudo e a reflexão sobre o problema do agir humano tenham a importância que merecem no seio da sociedade.

No universo da aprendizagem, sempre se está ganhando novos conceitos e refletindo, seriamente, sobre formas pedagógicas que possam somar, positivamente, para a formação de cidadãos. Dessa forma, uma aula de ética desenvolvida, através de atividades que aliassem a dimensão lúdica com a reflexão ética, mostrou-se um importante meio para a discussão e a formação ético-moral dos alunos. O Brasil, em consonância com seus princípios constitucionais de defesa dos direitos humanos e da dignidade da pessoa, deve levar essa realidade para a sala de aula, a fim de que os futuros cidadãos sejam melhor formados e preparados, para viverem numa sociedade democrática e justa.

O RPG, mais do que ser um simples jogo, mostrou-se capaz de despertar nos alunos a empatia pelo debate sobre dilemas éticos, pois os alunos, para 
conseguirem desenvolver a atividade, deveriam pressupor conhecimentos de outras áreas do saber, como História, Sociologia e Geografia. Assim, a aula ganha uma dimensão multidisciplinar, na qual há a possibilidade de um aprendizado variado de conteúdos, que contempla e conjuga várias dimensões do saber humano.

Tem-se consciência de que a ética em sala de aula, por si só, não tem o potencial de transformar ou regenerar a sociedade; contudo sua ausência do espaço escolar ou sendo desenvolvida e ministrada com meios pedagógicos precários, de forma que não cative os alunos, torna mais difícil a construção de uma sociedade na qual os valores éticos sejam primados e praticados por todos. Por isso, é indispensável que as aulas de ética não sejam apenas mais uma formalidade político-institucional, para cumprir requisitos de carga horária escolar ou saciar o ego de autoridades político-educacionais, mas, realmente, seja um tempo de debate maduro, sério e transformador na vida dos jovens alunos.

\section{Referências}

ABBAGNANO, Nicola. Dicionário de filosofia. São Paulo: M. Fontes, 2003.

ARISTÓTELES. Ética a Nicômacos. 3. ed. Bauru: Edipro, 2009.

BRASIL. Secretaria de Educação Fundamental. Parâmetros curriculares nacionais: apresentação dos temas transversais, ética / Secretaria de Educação Fundamental. Brasília: MEC/SEF, 1997. Disponível em:

<http://portal.mec.gov.br/seb/arquivos/pdf/livro081.pdf>. Acesso em: 10 dez. 2017.

BRASIL. Secretaria de Educação Fundamental. Parâmetros curriculares nacionais: apresentação dos temas transversais, ética / Secretaria de Educação Fundamental. Brasília: MEC/SEF, 1997. Disponível em:

<http://portal.mec.gov.br/seb/arquivos/pdf/livro082.pdf> Acesso em: 13 dez. 2017.

KANT, Immanuel. Réflexions sur l'éducation. Paris: Vrin, 1989.

MONDOLFO, Rodolfo. O pensamento antigo: história da filosofia greco-romana. 3. ed. São Paulo: Mestre Jou, 1971.

JONAS, Hans. O princípio da responsabilidade: ensaio de uma ética para a civilização tecnológica. Rio de Janeiro: PUC-Rio/Contraponto, 2006. 
15

UMA BREVE INTERPRETAÇÃO SOBRE A NÁUSEA, DE JEAN PAUL SARTRE

\author{
Danimar Bonai \\ dbonai@ucs.br \\ Suzy Menegat \\ smenegat999@gmail.com \\ Subprojeto Filosofia \\ Escola Estadual de Ensino Médio São Caetano*
}

Resumo: Nesse texto pretendemos apresentar algumas reflexões acerca da obra intitulada $A$ Náusea do filósofo Jean Paul Sartre. Nela, o autor parece elaborar uma argumentação em torno da temática da existência, como sendo esta uma eterna contingência. Tudo o que ocorre na vida poderia muito bem não se suceder ou ser de outra forma. Dar-se conta do caráter inusitado que é a vida pode ser uma grande sabedoria. Nesse sentido, vamos investigar se tais pressupostos têm plausibilidade no percurso da obra.

Palavras-chave: A náusea. Existência. Contingência. Sabedoria.

Jean Paul Sartre é um pensador europeu do século XX, que, influenciado por acontecimentos históricos de seu tempo, constrói uma doutrina existencialista que, segundo ele próprio, é uma doutrina de ação, otimista, que torna a vida humana possível, não podendo ser considerada, meramente, contemplativa, passiva e tampouco pessimista. Nesta forma de conceber o mundo, encontram-se os conceitos fundamentais que orientam seus escritos, como a liberdade, o humanismo, a subjetividade, a angústia, o desespero, dentre outros. Isso se verifica melhor na obra $A$ Náusea, através do personagem principal, Antonie Roquentin quando afirma:

\footnotetext{
Alguma coisa me aconteceu, já não posso mais duvidar. Isso veio como uma doença, não como uma certeza comum, não como uma evidência. Instalouse pouco a pouco, sorrateiramente senti-me um pouco estranho, um pouco incomodado, e foi tudo. (SARTRE, 2015, p. 13).
}

Por meio do romance, demonstram-se as ideias de Sartre a respeito da gratuidade das coisas e do homem reduzido à coisa em si, um certo nada no que tange às plenas possibilidades de ser algo e fuga de um determinismo a priori. Desse modo, o diário escrito por Roquentin traz à tona reflexões acerca do mundo em que vive e de sua própria existência. O personagem vive como uma

\footnotetext{
${ }^{*}$ Coordenador Prof. Dr. Luis Fernando Biasoli.
} 
coisa, tudo é gratuito, contingente. Ele não quer se prender a nada por muito tempo, embora nas suas ações se verifique o oposto, quando alimenta desejos passados por uma antiga amante casual.

Trata-se de uma obra filosófica, que nos indaga sobre a questão da existência ser algo em que o sujeito pode ou não agir de forma livre e criativa. Nesse sentido a arte, a história, nas palavras de Sartre $(2015$, p. 198) são “[...] como as que não podem acontecer, uma aventura". Juntamente com o engajamento político-apartidário, são os três pressupostos essenciais, para pensar numa vida que fuja de um determinismo natural e social tão somente.

O acaso aparece como tema central na obra, uma vez que é algo muito mais presente do que imaginamos e nos molda constantemente. Por sua vez, o destino é mais uma questão de interpretação. Existir não é uma necessidade. Assim, temos a náusea, entendida como um processo de dar-se conta do suposto absurdo que é existir. Como sugere o autor, o absurdo não seria uma ideia em sua cabeça, nem um sopro de voz, mas sim aquela serpente aos seus pés, mesmo que ele não a tenha buscado, mesmo que ele não precisasse dela. (SARTRE, 2015, p. 146). São momentos em que se sente uma falta de firmeza no viver, onde as coisas não possuem roteiro seguro com início, meio e fim.

A falsidade das relações pelo conceito de má-fé é outra questão recorrente no enredo. Nisso está presente a crítica à superficialidade ou a banalidade com que se vive, de modo a buscar o que se quer, comumente, de forma egoísta e falsa. Seria um agir sempre em função de um interesse subliminar. No momento em que está no café com o autodidata, o personagem principal Roquentin parece ser um espelho do próprio Sartre pelas suas posições tomadas, ou seja, no caso muito semelhante ao pensamento sartreano e a teoria existencialista. Nesse âmbito, é citado um casal que recém se conheceu e vive uma fantasia, mas sabendo já de antemão qual a finalidade da relação, a saber, terminará em sexo. Não obstante, este casal cria nuanças para vivificar a história, enganandose a si próprio.

Essas situações citadas são fatos da vida que demonstram a contingência da vida, sua banalidade e superficialidade. O que se vive de verdadeiro, poderíamos indagar. Nessa concepção, há um homem existente na sua contingência e gratuidade. Cabe lembrar uma ideia célebre da obra $O$ existencialismo é um humanismo, quando Sartre afirma que a existência precede 
a essência. (2012). Tudo o que há, poderia muito bem nunca ter surgido. Não se trata de um niilismo, mas sim de entender a existência como algo livre. O ser nessa apreensão é aberto à plena constituição de si.

Partindo da ideia de que a liberdade está presente, sobremaneira, na vida humana, cada qual é responsável pelo que fizer de si. Temos um forte peso nas deliberações individuais, visto que não se pode atribuir a outrem o peso de uma escolha pessoal equivocada. A filosofia humanista assume o ser humano como alguém só, livre, nu e que depende do que fizer de si, para que seu projeto de existir se constitua em alguma coisa.

A liberdade em meio à existência é a capacidade de fugir da trilogia passado-presente-futuro, e, dessa forma, de um determinismo ou de uma fatalidade que está à guisa da vida. É preciso ter coragem e consciência para tal. Isso aparece com ênfase, quando Roquentin esmaga a mosca numa conversa com o autodidata, de maneira a libertá-la dessa existência pré-determinada, visto que para o animal segue um curso biológico inexorável.

Isso leva Roquentin a desistir da escrita do livro sobre o marquês de Rollebon. Uma vez que ali teria uma história sem vida, já posta que só precisaria ser reconhecida ou interpretada em sua linearidade. Nenhuma aventura de fato. Como interpretar o sentido de aventura para o autor? Algo que não podemos prever, calcular, planejar? No decorrer da obra Roquentin narra um acontecimento, um menino se aproxima e murmura com ar extasiado: "Oh! O farol! Então senti meu coração inflado por um grande sentimento de aventura". (SARTRE, 2015, p. 66).

Ainda, podemos supor que seria como se um sentimento tomasse conta do personagem, a plena experiência surpreendente da contingência. Algo inesperado que transborda algum tipo de emoção que, por hora, parece suprir a carência, a falta, o nada que é existir, algo que insinua um valer-a-pena da existência. Sugere de forma interpretativa momentos de gratuidade. Posteriormente, ao referir-se à aventura descreve: "Finalmente me acontece uma aventura e, quando me interrogo, vejo que acontece que sou eu e que estou aqui; sou eu que fendo a noite, estou feliz como um herói de romance". (SARTRE, 2015, p. 67).

Apenas alguém vivendo a existência de outro, sendo outro, pela escrita de um livro que vivifica sua existência. Quando chegamos ao fim da obra, Sartre 
deixa entrever um otimismo sob uma constituição de vida diferente por meio da arte, pois ali não há roteiro, ela não se deixa antever, o que irá mudar em seus escritos filosóficos posteriormente. Seria a arte mais uma forma de atribuir algum sentido a existência? Roquentin ao longo de sua história explora a música: "Some of these days", de Ella Fitzgerald, como um meio de transportá-lo a algum lugar desconhecido, que por momentos o transforma em observador, interpretador dos acontecimentos e das pessoas que o rodeiam.

O fato de ser escritor e de poder criar histórias que jamais serão vividas, verdadeiras aventuras não o torna um artista? Seus escritos podem ser grandes obras de arte e, como o personagem sugere no final do romance, seus livros poderiam se tornar algo precioso, lendário. Em caráter interpretativo, seria sugerido que a arte poderia transformar meros acontecimentos em grandes aventuras.

Ainda, no romance, Roquentin pode ser entendido como alguém que está em projeto de escrever um livro e ainda não é. Apenas uma possibilidade de vir a ser algo, carregando o fardo da liberdade. Sobre ele se sentir nauseado constantemente está ligado à ideia de precisar se constituir como algo para dar sentido a existência, uma vez que nada têm sentido a priori. Os momentos da náusea emergem na apreensão contingente da vida.

Nesse contexto, Sartre elabora em sua teoria humanista um tipo de argumentação que delega ao sujeito plenas capacidades de constituição de si. Ser o que se é da melhor forma. Esse é um processo interno, que inclui, também, um contato com a sociedade de modo geral. Cada ser pode ser o que quiser, desde que respeite parâmetros mínimos de convivência. Desse modo, cabe ao sujeito deliberar bem de acordo com a sua vontade e as regras e mínimas de convivência. As coisas e os saberes sobre elas nunca estão, totalmente, prontos e evidentes; por hora é necessário descobrir as minúcias do conhecimento, das relações humanas. Viver é uma escola, uma obra de arte. A partir daí, vai se formando uma identidade interna.

Esse sujeito que vai se descobrindo e formando sua identidade deixará, pouco a pouco, de ser totalmente dependente das situações. De outro modo, ocorrerá a constituição de um agente ativo de sua própria história. Lembrando que Sartre coloca a liberdade sempre em face de uma situação, assim agir bem é levar em conta as possibilidades de ação. Jamais podemos nos sentir culpados 
por algo que não esteve ao nosso alcance, como é o caso de uma guerra mundial; no entanto, devemos adquirir um pouco de responsabilidade sobre aquilo, para que não venha a ocorrer.

A arte, a história e o engajamento político-apartidário parecem ser os caminhos mais profícuos, para construir uma base sólida sobre as diversas situações que envolvem o decurso contingente da vida. Não existe forma de negar a existência, de ser indiferente a ela, na obra Sartre $(2015$, p. 143) discorre: "A existência penetra em mim por todos os lados, pelos olhos, pelo nariz, pela boca..." Questionar o mundo faz parte desse processo. Defender ideias em que se encontrem fundamentos sólidos, vivenciar a obra de arte, constituir-se em aventura, talvez possa fazer mais sentido do que apenas contemplar o absurdo e contentar-se.

O existencialismo sartreano, muitas vezes, criticado por conduzir as pessoas à inação, traz nesse romance uma nova maneira de se dar conta sobre como é possível ver o mundo de forma diferente e de atribuir valor às deliberações. Algo que ocorreu, poderia muito bem não ter ocorrido ou mesmo ser de outro modo. Para tanto, é sob o conceito de liberdade que ressoa a noção de fazer e escolher por onde, e como fazer algo. Ali, as coisas tomam forma, o ser e o não-ser são percebidos. A História serve para que não nos esqueçamos do valor de cada coisa, da sua verdadeira formulação. Uma vida sem história carrega a perda de identidade, e no mesmo caminho se chega a uma distorção dos princípios. É preciso ter memória para ter história, como também para buscar saber a verdade.

\section{Referências}

SARTRE, Jean-Paul. $\mathbf{O}$ existencialismo é um humanismo. 2. ed. Petrópolis, RJ: Vozes, 2012.

A Náusea. Rio de Janeiro: Nova Fronteira, 2015.

Sartre por ele mesmo. Produção de Pierre-André Boutang e Guy Seligmann. Disponível em: <https://www.youtube.com/watch?v=wCS5V6nAWIk>. Acesso em: 7 jan. 2018. 


\title{
Letras Inglês e Pedagogia
}

\section{6}

\section{A REPRESENTAÇÃO FEMININA EM SALA DE AULA}

\author{
Igor Filipini Cearon \\ igor.cearon@gmail.com \\ Juliana Cordeiro Begnini \\ julianabegnini@gmail.com \\ Pibid-UCS Subprojeto Letras-Inglês
}

Escola Estadual de Ensino Médio Santa Catarina*

Resumo: O presente artigo visa, primeiramente, a propor uma reflexão acerca do conceito de construção de gênero e do fenômeno de apagamento sofrido por mulheres, no que tange ao desenvolvimento social, cultural, histórico, científico, econômico e político, trazendo à luz alguns estudos consagrados sobre o tema. Posteriormente, essa reflexão será usada como base para a fundamentação de um relato de experiência, descrevendo uma ação prática do grupo de bolsistas do Programa de Incentivo a Bolsas de Iniciação à Docência (Pibid) subprojeto de LetrasInglês da Universidade de Caxias do Sul (UCS), com turmas de 3ㅇ ano do Ensino Médio, da rede pública de ensino. A prática relatada visa à utilização do idioma para leitura, interpretação e produção textual, balizada sob o tema de visibilidade feminina e da representatividade das ações significativas em nível de crescimento social, promovido pelo Dia Internacional da Mulher. A prática tem, como fundamento, a divulgação de grandes feitos femininos e de personalidades de influência, nos mais diversos ramos do desenvolvimento social. Finalmente, serão expostas as considerações finais dos presentes bolsistas, acerca da prática e da sua influência sob o cenário de reflexão social e de uso da linguagem.

Palavras-chave: Representatividade feminina. Relato de experiência. Desenvolvimento social.

\section{Introdução}

A figura feminina, nos âmbitos de desenvolvimento da sociedade, sofre com o apagamento e com a pouca divulgação de seus feitos. Essa baixa representatividade enfraquece o movimento por equidade de gênero, principalmente nas áreas das ciências, da economia, da política e, também, no que tange a feitos históricos, culturais e de movimentos sociais de modo geral. Ocasiona, ainda, a desmotivação da mulher para a participação ativa em ações promotoras de desenvolvimento, uma vez que é notável a ausência de divulgação e de compartilhamento de conhecimento de produção feminina,

\footnotetext{
* Coordenadora Profa. Me. Maria Valéria Silva da Silva.
} 
dentro dos meios de divulgação, promoção e reconhecimento de crescimento de todos os âmbitos sociais.

Em busca de elucidar questões relativas à construção da identidade feminina e de promover o debate acerca da representatividade da mulher, dentro das áreas de desenvolvimento social com alunos de Ensino Médio da rede pública de ensino, o grupo de bolsistas do Programa de Incentivo a Bolsas de Iniciação à Docência (Pibid), do subprojeto de Letras-Inglês da Universidade de Caxias do Sul (UCS) - sob a coordenação da Profa. Mestra Maria Valésia Silva da Silva e a supervisão docente da Profa. Marcia Zambon Farias - promoveu uma atividade de uso da língua inglesa contextualizada pelo Dia Internacional da Mulher. A prática teve espaço na Escola Estadual de Ensino Médio Santa Catarina, e contou com a participação de seis turmas de 3ํano do Ensino Médio, cada uma composta por uma média de 35 alunos. A atividade promoveu a divulgação de grandes feitos femininos nas mais diversas áreas do desenvolvimento, bem como a utilização da língua inglesa contextualizada para a representatividade feminina, no Mês da Mulher.

\section{Fundamentação teórica}

O presente artigo visa a apresentar uma prática pedagógica balizada na representação feminina em sala de aula. Para tal, foi necessário compreender o conceito de gênero adotado e os sistemas de opressão que ocasionam o apagamento da figura feminina - no que tange ao desenvolvimento histórico e social - e que, assim, justificam a adoção da atividade em questão.

Primeiramente, é necessário diferenciar os conceitos de gênero e sexo. Tratando-se de gênero, Simone de Beauvoir (1967), importante liderança nas pautas feministas, defendia a feminilidade como algo socialmente construído, mais do que como um conjunto de fatores biológicos. Nesse sentido, afirmava:

\footnotetext{
Ninguém nasce mulher: torna-se mulher. Nenhum destino biológico, psíquico, econômico define a forma que a fêmea humana assume no seio da sociedade; é o conjunto da civilização que elabora esse produto intermediário entre o macho e o castrado, que qualificam de feminino.
}

A autora entendia gênero como uma construção dada por diversos fatores sociais, pelos quais constituía-se uma imagem ideal de mulher, de acordo com 
um conjunto de estereótipos ligados à figura feminina e ao papel que a mesma deveria desempenhar, dentro de um contexto sociocultural. Nesse sentido, segundo essa visão, "ser mulher" estaria ligado às ações desempenhadas dentro da cultura de determinado povo, não à constituição física e biológica do ser em si. Beauvoir defende ainda que, durante a infância e às fases de desenvolvimento psicossexual infantil, estabelecidas por Freud (2002), as crianças tendem a agir da mesma forma e ter as mesmas reações às situações a elas apresentadas, independentemente do gênero ou do sexo biológico nos quais se enquadram. Apenas depois, com o contato social, e durante a fase de construção de identidade, é que a criança passa a adotar comportamentos considerados masculinos ou femininos.

A abordagem beauvoiriana de gênero, com base no fator social, foi seguida, posteriormente, por muitos outros autores. Wardhaugh e Fuller, por exemplo, defendem:

\begin{abstract}
Por outro lado, gênero, embora baseado em categorias sexuais, é culturalmente construído. O que é considerado masculino ou feminino difere de uma sociedade para outra. Também é geralmente concebido como estando em um continuum de masculino e feminino, ou seja, você pode ser mais ou menos masculino ou feminino, enquanto as categorias de sexo são, geralmente, consideradas como grupos discretos, para que os indivíduos devam pertencer de forma firme e permanente a uma ou outra categoria. Dentro da teoria social contemporânea, as identidades de gênero, como outros aspectos da identidade, podem mudar ao longo do tempo e variam de acordo com a configuração, o tópico ou os interlocutores. $\left(2015\right.$, p. 313). ${ }^{1}$
\end{abstract}

De acordo com os autores, os conceitos de masculinidade e feminilidade diferem em sociedades distintas, apesar de baseadas em categorias sexuais fixas (macho e fêmea), biologicamente construídas. Isso demonstra que a diferença entre gênero e sexo parte do princípio de construção cultural versus fator biológico. Desta forma, para este texto, assim como para o projeto realizado, o termo gênero deve ser entendido como uma noção sociocultural, e qualquer

\footnotetext{
${ }^{1}$ On the other hand, gender, although based on sex categories, is culturally constructed. What is considered to be masculine or feminine differs from one society to another. It is also usually conceived of as being on a continuum of masculine and feminine, that is, you can be more or less masculine or feminine, while sex categories are generally thought of as being discrete groups so that individuals must firmly and permanently belong to either one or the other category. Within contemporary social theory, gender identities, like other aspects of identity, may change over time, and vary according to the setting, topic, or interlocutors. (2015, p. 313, tradução nossa).
} 
conceito a ele relacionado, inclusive aqueles relacionados à mulher e ao feminino, também considerará esse mesmo cenário de relação com as construções sociais de feminilidade e masculinidade, bem como dos papéis por ele desempenhados socialmente.

Quanto aos sistemas de opressão, é importante salientar a presença de um notável apagamento social quanto à figura feminina, principalmente no que tange aos campos das ciências e tecnologias. Soares exemplifica esse apagamento da seguinte forma:

[...] o escasso reconhecimento dentro da própria comunidade científica. Marie Curie é um clássico exemplo a ser citado. Foi necessário a recusa de Pierre Curie em receber o prêmio Nobel sozinho para que a comissão reconhecesse a contribuição de Marie na área de radioatividade. Mais tarde, a contribuição essencial de Rosalind Franklin para a elucidação da estrutura do DNA foi completamente ignorada pela comissão do prêmio Nobel. Outros exemplos podem ser facilmente encontrados em qualquer livro bibliográfico sobre mulheres cientistas. (2001, p. 282).

O mesmo pode ser percebido nas demais áreas de desenvolvimento: social, histórico e cultural. A pouca visibilidade e o reconhecimento das figuras femininas de destaque, em suas áreas, desincentivam novas participações de mulheres nos diferentes âmbitos de pesquisa e produção de conhecimento, restringindo, assim, o acesso e a inclusão feminina nas práticas relacionadas ao conhecimento científico e social.

Pode-se perceber, então, que maior divulgação da representatividade feminina, dentro dos âmbitos de desenvolvimento sociocultural, tem suma importância para a valorização e o incentivo à participação feminina em espaços relativos a esse desenvolvimento.

\section{Período de realização}

A unidade de ensino abaixo relatada teve duração de três semanas, utilizando-se dos dois períodos semanais de língua inglesa, conforme quadro descrito a seguir. 
Quadro 1

\begin{tabular}{|l|l|l|}
\hline \multicolumn{1}{|c|}{ FASE } & \multicolumn{1}{|c|}{ DESCRIÇÃo } & \multicolumn{1}{c|}{ DURAÇÃo } \\
\hline Primeira fase: Pesquisa & Leitura de biografias & Dois períodos de 50 minutos \\
\hline Segunda fase: Mapeamento & $\begin{array}{l}\text { Aplicação de quiz pela } \\
\text { ferramenta digital Kahoot }\end{array}$ & Um período de 50 minutos \\
\hline Terceira fase: Produção & $\begin{array}{l}\text { Produção de cartaz sobre as } \\
\text { biografias lidas }\end{array}$ & Três períodos de 50 minutos \\
\hline \multicolumn{2}{|r}{ Culminância: exposição de cartazes produzidos pelos alunos. } \\
\hline
\end{tabular}

A prática foi assim dividida, para que os alunos pudessem realizar uma compreensão aprofundada do tema, sem renegar o uso contextualizado da língua inglesa, de modo a aplicar o idioma em uma situação-alvo. Objetivou-se, ainda, oportunizar aos alunos a divulgação de suas produções e valorização do trabalho por eles desenvolvido, de modo a incentivar o uso do inglês para um fim específico: para a sua posterior exposição.

\section{Aplicação}

Considerando os estudos feitos, foi possível reconhecer a importância de abordar a representatividade feminina em sala de aula. A fim de abordar essa temática, dentro do cenário do Mês da Mulher (março de 2017), foi pensada uma atividade que abordasse os grandes nomes femininos relacionados a descobertas e produções artísticas, culturais, históricas, científicas, econômicas e políticas. A atividade foi desenvolvida com seis turmas de 3 o ano do Ensino Médio, da Escola Estadual de Ensino Médio Santa Catarina, cada turma composta por uma média de 35 alunos entre 16 e 18 anos. O projeto foi elaborado pelos autores do presente trabalho e realizado por todo o grupo de bolsistas do Pibid.

O objetivo da prática era utilizar a língua inglesa para leitura, compreensão e produção de textos, dentro do eixo temático do "Dia Internacional da Mulher", oportunizando aos alunos o contato com biografias em língua inglesa de personalidades femininas previamente selecionadas por seus feitos, dentro do desenvolvimento social e científico. A atividade foi dividida em três fases: pesquisa, mapeamento e produção. Na fase de pesquisa, com duração de uma 
semana (duas aulas), os alunos recebiam uma lista de nomes de mulheres de influência, tanto contemporâneas quanto em nível histórico. Posteriormente, divididos em grupos de seis componentes, deveriam ler as biografias daquelas que mais thes interessassem. Para isso, foram incentivados a procurar informações no site Biography e tomar notas do que achassem mais relevante.

A segunda fase, a de mapeamento, teve duração de uma aula, e consistiu de um quiz sobre as mulheres, que compunham a lista entregue aos alunos, utilizando a ferramenta digital Kahoot. Para tal, os alunos foram levados até o laboratório de informática da escola, que é constituído por 30 computadores, com acesso à internet. Os alunos utilizaram-se desses computadores para responder ao quiz e testar seus conhecimentos sobre cada uma das mulheres pesquisadas.

Finalmente, a fase de aplicação utilizou-se de três períodos de língua inglesa. Nessa etapa, cada grupo deveria escolher uma dessas personalidades e produzir, em língua inglesa, um cartaz com os principais fatos sobre a pessoa escolhida - enfocando, sempre, nos feitos relacionados ao desenvolvimento sociocultural, histórico, artístico, científico, econômico ou político. Esses cartazes foram dispostos alternadamente nos murais da escola durante um mês, para amplo acesso dos demais estudantes da escola, em espaços de circulação, com o objetivo de promover uma ampliação da prática para valorização da produção dos alunos e, também, para a divulgação da mulher como produtora do conhecimento e promotora do desenvolvimento. Como efeito, a prática também promoveu o incentivo à leitura em língua inglesa, uma vez que os demais alunos, ao pararem para prestigiar os trabalhos expostos por conta do apelo visual dos cartazes, sentiam interesse nas informações trazidas e buscavam-nas no texto.

A aplicação possibilitou aos alunos o contato de forma direta com material escrito autêntico em língua inglesa, a oportunidade de produção própria e divulgação dos resultados do processo. O acesso à informação oportunizou aos alunos uma nova visão da história mundial, considerando a mulher como indivíduo ativo no processo de desenvolvimento social, político, econômico e cultural. 


\section{Considerações finais}

A atividade realizada pelo grupo do Pibid teve uma importância simbólica na divulgação da participação feminina nos mais diversos âmbitos do desenvolvimento social, de modo a enriquecer a representatividade da mulher, dentro dos espaços de fala majoritariamente masculinos. Essa representatividade é importante para a motivação de outras mulheres a participarem ativamente do processo de crescimento da sociedade, já que a atuação feminina deixa de ser apenas abstrata e passiva para mostrar-se de fato significativa e ativa. Em nível social, a atividade proposta demonstrou ser relevante, uma vez que a temática não tem espaço dentro do currículo e, desse modo, é raramente abordada.

Já em nível de utilização da língua inglesa, a prática forneceu um uso contextualizado dentro do cenário de visibilidade feminina, promovido pelo Dia Internacional da Mulher, de modo que o idioma tornou-se significativo, uma vez que aplicado para um fim, e não apenas estruturalmente centrado. O contato com a leitura e a compreensão textual, bem como com a produção relacionada à estética do cartaz, envolveram não apenas os alunos da prática, mas também aos demais alunos da escola, já que a exposição do material produzido incentivou a leitura em língua inglesa, por meio do apelo visual.

A prática ofereceu aos alunos um novo uso da língua inglesa e uma nova visão social da mulher, em conjunto com as linhas de estudo feministas, em busca da visibilidade feminina e da equidade em nível de construção e divulgação de conhecimento, nas mais diversas áreas; desse modo, uniu a utilização da língua estrangeira à sociedade e, acima de tudo, ao acesso à informação, real objetivo da língua estrangeira na escola pública.

\section{Referências}

BEAUVOIR, Simone de. 0 segundo sexo: a experiência vivida. 2. ed. São Paulo: Difusão Européia do Livro, 1967. v. 2.

FREUD, Sigmund. Três ensaios sobre a teoria da sexualidade. Rio de Janeiro: Imago, 2002. 
SOARES, Thereza Amélia. Mulheres em ciência e tecnologia: ascensão limitada. Química Nova, [s.I.], v. 24, n. 2, p.281-285, abr. 2001. FapUNIFESP (SciELO).

WARDHAUGH, Ronald; FULLER, Janet M. An introduction to sociolinguistics. [S.I.]: John Wiley and Sons, Inc., 2015. 
17

\title{
EGOCENTRISMO: DIVERGÊNCIAS ENTRE O ESTUDO DO CONCEITO E A ATUAÇÃO DOCENTE DO PIBID NA EDUCAÇÃO INFANTIL
}

\author{
Bolsista Pibid: Karlani Machado \\ Coordenadora: Dra. Cristiane Backes Welter \\ Supervisora: Márcia Regina Giacomelli Schleder \\ Subprojeto Pedagogia \\ E-mails: Lanimachado99@gmail.com, necaschleder@gmail.com, \\ cbwelter@ucs.br \\ Escola Municipal de ensino Fundamental Zélia Rodrigues Furtado
}

\begin{abstract}
Resumo: Esse trabalho visa a relatar a compreensão do conceito de Egocentrismo, a partir dos estudos de Piaget e os resultados da investigação sobre o comportamento de crianças matriculadas em duas turmas de Educação Infantil, na cidade de Caxias do Sul, que preocupavam os professores por apresentarem atitudes identificadas pelos mesmos como egocêntricas. A pesquisa é financiada pelo Pibid - Programa Institucional de Bolsa de Iniciação à Docência 2017, do Subprojeto Pedagogia, área de Letramento e Educação Infantil, fomentado pela Coordenação de Aperfeiçoamento de Pessoal de Nível Superior (Capes), sendo esta pesquisa realizada pelas bolsistas do Pibid na Escola Municipal de Ensino Fundamental Zélia Rodrigues Furtado, localizada no Município de Caxias do Sul/RS. O objetivo é investigar as principais características do comportamento infantil relacionadas ao egocentrismo, através do estudo desse conceito em Piaget e da realização de práticas docentes de bolsistas do PIBID em duas turmas de Pré-Escola, com crianças na faixa etária de 5 anos a 5 anos e 11 meses. A pesquisa sobre o termo egocentrismo, a partir dos estudos de Piaget, permitiu compreender os equívocos do uso do termo no senso comum, como apropriado para atitudes individualistas de crianças que aprendem a conviver com outras crianças da mesma idade. De modo geral, as crianças das turmas nas quais se realizaram as práticas pibidianas ${ }^{1}$ demonstraram estar atentas à exploração de características exigidas pela cooperação propostas pelas atividades lúdicas. Esse resultado mostrou-se divergente das atitudes egocêntricas destacadas inicialmente pelos professores das turmas no início da investigação.
\end{abstract}

Palavras-chave: Egocentrismo. Pibid. Educação Infantil.

\section{Introdução}

Este trabalho relata uma pesquisa bibliográfica realizada através do Pibid Programa Institucional de Bolsa de Iniciação à Docência 2017, do Subprojeto Pedagogia, área de Letramento e Educação Infantil, fomentado pela Capes, sendo este trabalho realizado pelas bolsistas do Pibid na Escola Municipal de

\footnotetext{
${ }^{1}$ Práticas pibidianas é uma expressão utilizada desde o primeiro ano do Projeto Pibid em curso de Pedagogia da Universidade de Caxias do Sul, para diferenciar as atividades realizadas pelos bolsistas de iniciação à docência do Pibid dentro das escolas de outros bolsistas, monitores ou outros profissionais em estágio na docência.
} 
Ensino Fundamental Zélia Rodrigues Furtado, localizada no Município de Caxias do Sul/RS. O objetivo foi investigar as principais características do comportamento infantil relacionadas ao egocentrismo, através do estudo desse conceito em Piaget e da realização de práticas docentes de bolsistas do Pibid em duas turmas de Pré-Escola, com crianças na faixa etária de 5 anos 5 anos e 11 meses.

As bolsistas pibidianas de pedagogia observaram algumas aulas sem interferir nas atividades planejadas pela professora e supervisora do Pibid na Escola, para poderem atentar-se a comportamentos que julgassem relacionados com egocentrismo infantil. Percebe-se diversas atitudes individualistas em trabalhos com proposta coletiva; na sequência, buscou-se suporte nos estudos de Piaget sobre esses comportamentos infantis na teoria e, após, pensa-se em estratégias a serem realizadas com as turmas de Educação Infantil, a fim de auxiliarem na diminuição do egocentrismo nos indivíduos, por meio da ludicidade.

As bolsistas do Pibid, que atuaram com o Projeto na Escola parceira do curso de Pedagogia em Caxias do Sul, eram oito estudantes do curso de Pedagogia: Adriana da Rocha Pereira, Andréia Zimmer, Cláudia Ferreira, Jéssica Alderete da Silveira, Karlani Machado, Lidiane Benites Soares, Maria Eduarda Ribeiro da Silva e Vanessa Marques Pessoa. A proposta de iniciação à docência do Pibid permitiu às bolsistas atuarem na docência da Educação Infantil, com o professor supervisor do Pibid, na instituição parceira e a coordenadora do subprojeto que foi professora no curso de Pedagogia, na Universidade de Caxias do Sul.

A atuação conjunta e colaborativa das bolsistas de iniciação à docência do Pibid, com o estudo do conceito de Egocentrismo em Piaget, assim como com as novas experiências com as crianças da Educação Infantil, mudou-se a compreensão do que são atitudes egocêntricas e como elas se manifestam em crianças matriculadas em turmas de Educação Infantil, dando a devida importância para a teoria e a prática. 


\section{Metodologia}

O estudo do conceito de egocentrismo foi realizado com base no estudo de obras de Piaget, que pesquisou o desenvolvimento de crianças e identificou, em seus estudos, comportamentos e fases do desenvolvimento infantil. Os encontros de estudos das obras de Piaget ocorreram em horários semanais do grupo do Pibid subprojeto Pedagogia. Já as práticas pibidianas foram planejadas com antecedência pelas bolsistas pibidianas e realizadas na EMEF Zélia Rodrigues Furtado, no turno da manhã e da tarde, nas turmas de Educação Infantil, com o objetivo de investigar as principais características do comportamento infantil, identificado como egocentrismo. Esse projeto é um recorte do Projeto de Pesquisa que desenvolvemos desde 2014, e que tem como objetivo maior inserir o letramento de forma lúdica e agradável no universo infantil.

Nestas semanas, que se referem aos meses de agosto até novembro de 2017, foram realizadas atividades lúdicas e cooperativas relacionadas a observações e relatos das situações ocorridas em turmas de Educação Infantil, para comparar as ações e os comportamentos dessas crianças na faixa etária de 5 anos a 5 anos e 11 meses, com as principais características do egocentrismo identificadas por Piaget.

\section{Resultados e discussão}

O egocentrismo vem a ser algo como insistência preconcebida no seu próprio ponto de vista, quando comparado ao de outras pessoas. 0 egocentrismo infantil foi a motivação mais importante nos primeiros livros de Piaget, e suas primeiras colocações foram mal compreendidas. Até 1924, ele o associava com o comportamento social e verbal da criança.

Piaget descreveu o egocentrismo como fenômeno abrangente. Manifestase através da pouca distinção entre realidade e fantasia e, até metade dos anos 30, considerava o egocentrismo como característica geral do pensamento infantil.

Nas hipóteses de pesquisa, cogitaram-se as seguintes questões, as duas turmas de Educação Infantil observadas são compostas por algumas crianças que são filhos únicos, o que configura uma situação em que a criança não terá maior 
interação com outros de sua idade e por vezes acaba não conhecendo pessoas em seu estágio ou até mesmo cria-se uma limitação do ambiente que a cerca, a saber filho único. Sendo sozinha, o único momento de interação se dá na escola (quando incentivada). Porém, por vezes, é incentivada na escola enquanto, em casa, os pais realizam motivações contrárias. Mesmo sendo incentivada a interação na escola, as crianças que recebem atenção exacerbada da família fazem com que a criança se confunda, exigindo na escola toda a atenção do professor.

Nessa primeira questão, criou-se um equívoco entre o desenvolvimento de crianças pequenas, pensando no cenário de filhos únicos, e o compromisso das instituições públicas de Educação Infantil e os núcleos familiares, dando a entender que, sendo filho único, uma criança não teria tantas possibilidades de interação na escola e em outros ambientes sociais, por ter atenção somente para si em seu lar. Isso se mostrou um equívoco, pois todas as crianças, nas instituições de Educação Infantil, têm direito à educação e à socialização independentemente de serem filhos únicos.

O segundo ponto se dá em relação às crianças que demonstram falta de afeto, pois exigem maior atenção do professor e, por isso, precisam aprender a trabalhar de forma coletiva. Ou seja, se por um lado fosse destinada uma atenção acentuada, estariam fortificando a noção de a criança ser o centro; por outro lado, o oposto também é válido, quando depara-se com uma criança carente, ou que não tem suas necessidades básicas supridas (alimento, abrigo, saúde, etc.). No momento em que essa criança tende a se tornar autônoma por força própria e sem vínculos mais afetivos, gera-se um reflexo de sobrevivência, em que "o outro vale menos que eu".

Sendo assim, quando ainda não havia uma compreensão aprofundada do conceito de egocentrismo, utilizou-se o senso comum para construir as hipóteses da pesquisa. Ao retomar as duas questões apresentadas acima, identificou-se engano entre egoísmo e egocentrismo. Se egocentrismo, segundo Piaget (1975), é compreendido como um comportamento, o egoísmo tem um significado diverso, segundo o mesmo teórico.

O egoísmo pode ser entendido como o hábito ou a atitude de uma pessoa que coloca seus interesses, opiniões, desejos, necessidades em primeiro lugar, em detrimento (ou não) do ambiente e das demais pessoas com quem se 
relaciona. Nota-se que atribui-se o significado de egoísmo na primeira questão, discutida anteriormente, quando fora proposto que filhos únicos seriam mais egocêntricos do que as demais crianças da turma de Educação Infantil investigada. Apoiados na teoria de Piaget, observou-se novamente a realidade e foi possível constatar que crianças que não tinham irmãos possuíam tendência mais egoísta, pois não precisavam preocupar-se em dividir brinquedos com outras crianças em sua casa. Já na escola, as atividades de interação exigiam dividir, compartilhar e isso gerava conflito. Da mesma forma, verificou-se, também, que as crianças com falta de afeto ou carentes de necessidades básicas, apresentadas na segunda questão, demonstravam atitudes egoístas durante as atividades de interação e cooperação, pois buscavam suprir seus desejos de maior atenção, ou suas necessidades de afeto, colocando isso como mais importante do que outras crianças presentes na turma.

No entanto, o significado de egocentrismo é o conjunto de atitudes ou comportamentos indicando que um indivíduo se refere essencialmente a si mesmo. O egocentrismo consiste em uma exaltação excessiva da própria personalidade, fazendo com que o indivíduo se sinta como o centro da atenção. Uma pessoa egocêntrica não consegue demonstrar empatia, ou seja, não consegue colocar-se no lugar do outro, porque está constantemente ocupada com o seu "eu" e com os seus próprios interesses.

Sendo assim, somente uma das hipóteses se mostrou coerente com o pensamento que obteve privilégio no estudo: aquela em que se afirmou que a falta de interação da criança que não é estimulada provoca uma não experimentação do meio. A criança que não é estimulada com base nas percepções sociointeracionistas acaba não tendo oportunidades de descobrir o mundo e percebê-lo, de modo a não trabalhar seus pensamentos, no que se refere à equilibração e assimilação. Quanto mais experiências com o outro, mais experiências com o meio, ela vai percebendo um mundo além do seu, além de suas perspectivas. Ou seja, um mundo que não depende do seu para existir, o que para Piaget pode ser chamado de descentralização. O "Eu" faz parte de um mundo comum a todos e não todos do meu mundo.

Em vista disso, procurou-se realizar várias atividades coletivas, para que as crianças pudessem ampliar suas ações cooperativas em sala de aula; logo, as bolsistas buscaram ter mais atenção para que não fossem novamente 
confundidos os termos, a fim de obter boa qualidade na execução das atividades, ao serem colocadas em prática na sala de aula. Compreende-se que é muito fácil cometer esse erro, quando não estudado mais a fundo, o que de fato significa o egocentrismo, o qual, na presente pesquisa, trata-se de uma fase que ocorre no processo do desenvolvimento infantil, complexa e que pode ser mais perceptível em alguns indivíduos e em outros nem tanto.

Conforme Piaget (1999, p. 34), a linguagem egocêntrica é o grupo constituído pelas primeiras categorias precedentes:

Repetição: A criança se identifica como objeto imitado.

\begin{abstract}
Mas, esse jogo, que parece uma atitude essencialmente social, é ao mesmo tempo essencialmente egocêntrico: os gestos e as condutas imitadas não interessam à criança por si mesma, e não há um eu que se adapta a outro, há uma confusão na qual a criança não sabe que imita, e desempenha seu papel como se tivesse criado. (PIAGET, 1999, p. 11).
\end{abstract}

Monólogo: Ausência do objetivo de expressar-se socialmente, servindo para reforçar seu próprio pensamento ou ação. Havendo na concepção de Piaget (1999, p. 16) um simples desvio da função principal da linguagem, em que a criança dá ordens a si mesma e às coisas, ou fala consigo mesma.

Monólogo coletivo: Resume-se à relação de monologar para atrair a atenção e o interesse dos demais, em seu próprio pensamento. Todavia, como já se observou, a criança que dialoga desse modo não consegue se fazer entender, afinal, não se dirige diretamente a ninguém. Fala alto para si mesma, diante dos outros. (PIAGET, 1999, p. 17). Permanece em sua fala para si mesma, independentemente de ter sido notada ou não.

Desta forma, foram observadas essas três categorias agrupadas em atitudes das crianças, como, por exemplo, na observação do dia 29 de agosto de 2017: em uma atividade de pintura, houve a imitação das cores utilizadas nos desenho de colegas que chamavam mais atenção a cada um, fazendo uso da repetição. $O$ monólogo também esteve presente em quase todas as ações ao dizer baixinho: "Agora vou pintar de amarelo". E assim por diante. Já o monólogo coletivo evidenciava-se praticamente do mesmo modo, porém, em tom de voz mais alto, a fim de chamar a atenção de colegas, da professora, monitora e das 
bolsistas do Pibid presentes na sala, para a visualização de seu desenho, demonstrando também o sentimento de ansiedade à espera de um elogio.

Piaget $(1999$, p. 36) afirma que até certa idade as crianças agem e pensam de maneira mais egocêntrica que o adulto, pois, ao mesmo tempo em que expõem de maneira audível seus pensamentos, trocam menos suas pesquisas intelectuais entre si do que os adultos. "Parecem falar mais entre si sobre o que fazem quando estão juntas, mas grande parte do que dizem não é dirigido a ninguém. Nós, ao contrário, omitimos por mais tempo em nossa ação, mas nossa linguagem é quase sempre socializada".

Nessa perspectiva, o adulto é mais individualizado, pois possui a capacidade de trabalhar na sua intimidade, sem anunciar a todo instante o que está fazendo, e mais socializado, pois pensa socialmente mesmo quando está só, conseguindo imaginar pessoas reais, físicas. Estabelece um pensamento já possível para uma compreensão socializada. Já a criança não é individualizada, pois não é capaz de conversar no íntimo nenhum dos seus pensamentos, expõe tudo, e cada ação dos membros do grupo repercute imediatamente sobre quase todos os outros, por imitação.

Logo, para Piaget (1999, p. 39), compreende-se que também não é socializada, pois essa imitação não é acompanhada por uma troca de ideias, afinal quase todos possuem esse pensamento egocêntrico. Portanto, não falam para serem entendidos, a menos quando desejam algo e ao dar ordens.

Em suma, no pensamento egocêntrico, a criança pequena procura adaptarse à realidade, embora não se expresse como é a realidade:

O pensamento da criança é realista e o progresso consiste em desembaraçar-se desse realismo inicial. Com efeito, durante os estágios primitivos, a criança não tendo ainda a consciência de sua subjetividade, todo real é disposto em um plano único por confusão dos dados externos e internos. [...] Do ponto de vista da causalidade, todo o universo é passível de estar em comunicação com o eu e a ele obedecer. Os desejos e as ordens do eu são considerados absolutos, porque o ponto de vista próprio é considerado como o único possível. Há egocentrismo integral por falta da consciência do eu. (PIAGET, 1975, p. 37).

Pode-se compreender que, quando a criança não tem noção de sua subjetividade, ou seja, suas próprias opiniões, gostos, desejos, etc., tem a tendência de obter um egocentrismo integral, em todas as partes, 
demonstrando isso de forma mais "óbvia", pois é fortemente "influenciada". Afinal, confunde-se com coisas internas e externas.

Nos trabalhos do projeto de pesquisa, buscou-se realizar atividades coletivas em rotinas já estabelecidas na vida escolar das turmas, mas que mudaram o modo de agir das crianças, pois puderam visualizar um pouco mais do outro, além de si mesmos. Por exemplo, na trilha dos pezinhos: essa foi uma experiência feita em duplas, de modo que as duas crianças precisavam andar juntas para alcançar o final da trilha. Por vezes, uma criança desejava ser mais rápida que a outra, mas acabava percebendo que não era o melhor jeito, pois precisavam ir juntas do início ao fim lado a lado. Por vezes, caíam e precisavam levantar-se juntas, criando assim a necessidade de empatia. Isso é algo que parece simples aos olhos dos adultos, mas, para as crianças na Educação Infantil, é um grande desafio, pois necessitam esperar e compreender o tempo do outro.

As estratégias didáticas propostas pelas bolsistas do Pibid eram uma prática de atuação docente pouco habitual nas turmas de Educação Infantil investigadas. Por isso, os jogos de cooperação foram pontos cruciais para que se iniciasse uma mudança de comportamento, pois o objetivo desses jogos é despertar a consciência de cooperação e promover efetivamente a ajuda entre as pessoas, além de serem importantes para a diminuição de atitudes egocêntricas.

Em uma das práticas pibidianas propostas - a saber, a pintura de um desenho em equipe - registrou-se o seguinte diálogo:

Profe Vanessa se direciona ao aluno A:

Profe Vanessa: e tu não queria pintar de rosa aí?

[Aluno A balança a cabeça falando não]

Profe Vanessa: Não? Mas tu deixaria a colega pintar?

[Aluno A balança cabeça falando sim]

Profe Vanessa: E não era melhor ter um trabalho só teu?

[Aluno A balança a cabeça falando sim]

Identifica-se a dificuldade do aluno A em compreender a nova situação, ou seja, ele pintava o desenho em conjunto com os colegas e demonstrava gostar, apesar de continuar com a ideia de que fazer somente de seu jeito seria mais interessante. Desse modo, já foi possível observar uma mudança no seu ponto de vista, a de que trabalhar com o outro também pode ser interessante. 
Esses diálogos foram sendo modificados a cada nova experiência em conjunto, proporcionada para as crianças interagirem com seus colegas. $\mathrm{Na}$ atividade de encerramento do projeto, por exemplo, houve a contação da história "Brinquedos", do autor André Neves, na qual todos compreenderam a essência do brincar, pois interagiram na ludicidade da história contada pelos fantoches, demonstrando uma postura de relacionar com o outro seu ponto de vista.

Os brinquedos auxiliaram-nos a expressar sentimentos e pensamentos de que eles não gostariam de ir para o lixão também, conforme conta a história. $E$ que lhes agradaria ficar perto de quem gosta para serem bem-tratados. Sendo assim, colocaram-se no lugar dos bonecos, experimentando outras visões sobre seus próprios brinquedos. Além do que, ficaram empolgadíssimos com a fabricação de seus fantoches, preocupando-se com os colegas que não estavam para confeccioná-lo e se oferecendo para ajudar, quando notavam que algo estava errado na produção do colega.

Preocupavam-se para além daquilo que era individual, gostavam de compartilhar as ideias, e o mais interessante é que passaram a questionar: se o outro tinha entendido o exercício, se conseguira fazer o que foi pedido, ajudavam e também pediam ajuda quando não conseguiam, passaram a deixar de lado o pensamento de que precisavam conseguir realizar tudo sozinhos.

Portanto, foi-se construindo uma ponte entre a teoria e a prática; logo criaram-se várias sugestões para proporcionar ações de aprendizagem nas aulas. Mudanças foram perceptíveis nos comportamentos das crianças, diante das situações expostas, uma vez que se tornaram mais compreensíveis.

$\mathrm{Na}$ última semana, em que as bolsistas pibidianas estiveram com as turmas de Educação Infantil, foram relembradas com eles todas as atividades feitas; eles mesmos puderam perceber que compreendiam um pouco mais do sentimento do outro e buscavam entender os demais pontos de vista. Observou-se que resolviam seus conflitos de forma mais independente, pois o trabalho coletivo exigia uma conversa, uma colaboração de cada um para que as propostas feitas pela professora e bolsistas do Pibid funcionassem de forma que todos ficassem satisfeitos com o resultado final de suas pinturas, apresentação teatral, bonecos, contação de história, etc. 
Foi muito interessante perceber essas modificações mencionadas anteriormente. Afinal, através de experiências lúdicas, como as brincadeiras propostas, passaram a vivenciar experiências coletivas e distintas do que estavam habituados; desse modo, entenderam que cada indivíduo tem seu tempo, seu espaço e seu ponto de vista. Com isso, tiveram auxílio para aprender a conviver com essas diferenças no cotidiano escolar. O estudo da teoria de Piaget, especialmente sua compreensão sobre o egocentrismo, auxiliou para que as bolsistas ficassem mais atentas às características do comportamento egocêntrico e, especialmente, às possibilidades de ações a serem propostas, que permitissem maior interação entre as crianças.

\section{Conclusões}

O egocentrismo é um comportamento muito interessante para ser pesquisado, atuando no espaço escolar, enquanto bolsista de iniciação à docência. Aliando a teoria com a prática, percebeu-se o quão importante é dar atenção para as fases do desenvolvimento das crianças e contribuir para a criação de espaços e estratégias pedagógicas, que permitem maior interação entre as crianças na Educação Infantil.

No decorrer das descobertas, apreendeu-se também que o uso do termo, no senso comum em geral, se dá em relação ao equívoco entre os termos de egoísmo e egocentrismo. Mas, na verdade, são palavras com significados bem distintos. Por fim, absorveu-se que o egocentrismo se manifesta através da pouca distinção entre realidade e fantasia, sendo uma confusão inconsciente do ponto de vista próprio com o do outro.

Um dos principais pilares sobre os quais as pibidianas de pedagogia debruçaram-se foi a proposta de atividades em sala de aula, como os jogos de interação e de cooperação, que influenciaram de maneira positiva o comportamento das crianças, para que se iniciasse a transformação da ideia que o mundo é um centro ao seu redor, para a de que o mundo é meu, mas também de outro(s). Percebeu-se que as crianças da Educação Infantil, na faixa etária de 5 anos a 5 anos e 11 meses, com as quais as bolsistas puderam conviver e realizar investigações sobre o egocentrismo, amadureceram e passaram para outra fase do desenvolvimento infantil, compreendendo a necessidade do outro. 
O lúdico, nas atividades em equipe que tinham ênfase na interação e cooperação, tornou-se uma estratégia pedagógica importante na rotina e no cotidiano escolar da Educação Infantil investigada. Dessa forma, a atuação docente das bolsistas do Pibid permitiu que compreendessem a urgência da investigação na escola. É necessário ao docente, que atua com crianças dessa faixa etária, que procure o suporte teórico, para que possam preencher as lacunas de propostas de ensino aprendizagem de maneira eficaz e coerente com a realidade de crianças pequenas e com características de egocentrismo.

\section{Referências}

CAMPOS, Cristiane. Apostila Psicologia do Desenvolvimento: Ciclo Vital (Unidade um). Ano. Disponível em: <https://www.passeidireto.com/arquivo/6392649/1-apostila-dedesenvolvimento-humano-e-ciclo-vital-i>. Acesso em: 18 jan. 2018.

FONZAR, Jair. Piaget: do egocentrismo (história de um conceito). 1986. Disponível em: <http://www.scielo.br/scielo.php?script=sci_arttext\&pid=S0104-40601986000100006>. Acesso em: 18 jan. 2018.

PIAGET, Jean. A linguagem e o pensamento da criança. 7. ed. São Paulo: M. Fontes, 1999.

PIAGET, Jean. A representação do mundo na criança. Rio de Janeiro: Record, 1975. 


\section{B. RESUMOS EXPANDIDOS E RELATOS DE EXPERIÊNCIA}


AULAS DE MÚSICA PARA O ENSINO NORMAL - RELATO DE EXPERIÊNCIA

\author{
Miraci Jardim \\ miracij@gmail.com \\ Mateus Castilhos \\ mateus.castilhos.97@gmail.com \\ Leandro Lindemann \\ IImoralesluiza22@gmail.com \\ Liruan Cortelett \\ liruan@terra.com.br \\ Subprojeto Música Pibid-UCS*
}

Resumo: Este artigo tem como objetivo descrever e relatar as experiências vivenciadas pelos bolsistas do Programa de Iniciação à Docência, da Universidade de Caxias do sul (Pibid/UCS), do subprojeto Música, no período letivo de 2017 com os alunos do 10 ao 3o ano do curso Normal do Instituto Estadual de Educação Cristóvão de Mendoza, a fim de possibilitar discussão e reflexão sobre as formas do ensino e aprendizagem, dentro da educação básica na área da música.

Palavras-chave: Educação musical. Relato de experiência. Pibid música.

\title{
Introdução
}

O presente trabalho tem como objetivo descrever as aulas dos bolsistas do subprojeto Música do Pibid UCS, no curso Normal do Instituto Estadual de Educação Cristóvão de Mendoza, em 2017, a partir da mudança no grupo de bolsistas, da reflexão sobre o trabalho anterior, da estratégia adotada para retomar os trabalhos até as aulas propriamente ditas. Todas as atividades aqui relatadas estão descritas nos Diários de Campo do blog Pibid-UCS/Música.

Nosso plano de aulas consistiu em trabalhar com alunos do curso normal, na perspectiva de que iriam reproduzir, no seu trabalho de professoras do ensino básico, nas séries iniciais e na Educação Infantil, as atividades que passaríamos nas aulas. Nesse sentido, tínhamos a preocupação de que os conceitos trabalhados muito provavelmente seriam adaptados na prática futura, desde que houvesse compreensão suficiente, que proporcionasse a análise e a crítica

\footnotetext{
${ }^{*}$ Coordenador do subprojeto (2o semestre de 2017): Prof. Luiz Ortiz Oliveira Filho; coordenadora anterior: Profa. Dra. Cristina Mie Ito Cereser. Supervisora: Profa. Mariá Isser Vaz.
} 
necessárias para possíveis transformações, adaptações e simplificações que, porventura venham a ser feitas. Com o intuito de otimizar o tempo de trabalho que teríamos, identificamos que seria necessário conhecer a realidade da experiência musical das nossas alunas, para elaborarmos nossas aulas e conseguir torná-las objetivas e focadas no essencial, em termos de conceitos musicais, dando base ao conhecimento e suprindo de práticas educativas, que sejam adequadas para o universo infantojuvenil e, por fim, provocar e estimular a reflexão sobre o trabalho feito e sua aplicação no trabalho futuro.

Dos autores da área da educação musical cuja obra tivemos contato no curso de Licenciatura em Música da UCS e que embasou nossas atividades em sala de aula, surgirão no decorrer do relato nomes como Keith Swanwick e Émile J. Dalcroze, citados com a intenção de estabelecer relações entre as práticas adotadas e nosso pensamento sobre os tópicos abordados nas aulas. Além dos nomes citados, é importante fazer referência a Edgar Willems, Carl Orff e John Paynter, como compositores e teóricos que fazem parte do conjunto dos saberes e das práticas da educação musical.

\section{Plano inicial}

Como estratégia de reconhecimento das turmas e dos alunos com os quais iríamos trabalhar, elaboramos um questionário com apenas quatro perguntas, que investigassem sobre a experiência prévia de qualquer natureza (teórica ou prática, profissional ou amadora) com música, sobre a possível atuação, presente ou passada (ou se nunca atuaram) em sala de aula e sobre demandas quanto às aulas de música que íamos ministrar. Utilizamos um pouco do tempo de uma aula da professora-supervisora do Pibid, como um encontro de reconhecimento, quando fomos apresentados, e distribuímos o questionário que havia sido projetado, justamente, com um número suficientemente curto de questões, para não ocupar mais do que quinze minutos de aula.

Com base nas respostas dos questionários, identificamos que a maioria dos alunos não tem, ou tem muito pouca experiência com a prática musical ou com o ensino musical, o que nos deu certeza quanto à necessidade de supri-los de um conhecimento básico sobre os elementos constitutivos da música, do som, como matéria-prima, seus parâmetros e as diferentes maneiras de percebê-lo, produzi- 
lo e de organizá-lo. Em função do tempo de trabalho que teríamos, priorizamos modelos de aulas em que os conceitos teóricos estivessem inseridos nas atividades práticas, de modo que todo conceito fosse antecedido pela experiência e confirmado pela mesma, dentro do que aprendemos sobre "métodos ativos da educação musical". (FIGUEIREDo).

Quanto à realidade profissional dos alunos, constatamos que poucos já estão trabalhando em sala de aula ou inseridos de alguma forma no ambiente escolar. Consideramos que essa realidade tem estreita relação com as demandas e expectativas que foram colocadas nas respostas. Alunos que já fazem parte do ambiente escolar tendem a ter uma visão funcional da música, relacionando-a com atividades cotidianas do universo infantil (comer, dormir, relações afetivas familiares...) e até mesmo com a "necessidade" de "acalmar" as crianças e organizar o espaço de sala de aula.

Diferente desses, os alunos que ainda não estão atuando nesse universo se mostraram mais abertos quanto às possibilidades e aplicações das práticas musicais. De modo geral, todos associam a música ao desenvolvimento motor, à concentração e à sua utilização como apoio na memorização de conceitos, o que pode ser considerado como uma questão paralela na música, ou seja, o texto que ela carrega.

É importante que todo educador, que faz uso da música como recurso didático, tenha conhecimento e clareza sobre as características do som que a gera, dos elementos básicos da música e seus aspectos culturais, pois muitas das atividades podem ser criadas pelo educador, a partir do seu objetivo e do material humano e técnico disponível, sem a necessidade de repetir fórmulas prontas ou de se limitar a um repertório de canções conhecidas e veiculadas diariamente pela mídia. Tal articulação entre teoria e prática faz do professor um ser que cria, um "produtor de conhecimento". (AzEVEdo; Grossi; MonTANDON, 2008).

Por fim, definimos os tópicos necessários a serem abordados e que nossas aulas seriam distribuídas na seguinte ordem de assuntos: parâmetros do som intensidade e duração; parâmetros do som - timbre e altura; percussão corporal fabricação de instrumentos com material alternativo. 


\section{Aulas sobre os parâmetros do som - intensidade e duração}

Os parâmetros do som chamados intensidade e altura foram apresentados aos alunos por meio de audiovisual, com um trabalho chamado "Capitão musical", no qual mostrava de forma lúdica e com onomatopeias os quatro parâmetros (altura, intensidade, duração e timbre). Nosso plano de aula consistia em capturar a atenção dos alunos, através do vídeo, fixando os conceitos que iríamos trabalhar e, posteriormente, representá-los com movimentos corporais em um processo de escuta e expressão, visando à compreensão da música e integrando a mente e o corpo. Esse processo está ligado à pedagogia musical elaborada pelo educador e compositor suíço Émile Jaques-Dalcroze (1865-1950), para quem o corpo serve de "intermediário" entre a música e a mente, no processo de compreensão, e que a "consciência rítmica" é resultado da "experiência corporal". (MATEIRO, 2012).

Explicamos que a atividade consistiria em ouvir, perceber e representar os parâmetros com o movimento do corpo e, para isso, tínhamos escolhido a música Habanera da ópera "Carmem", de Georges Bizet, porque é nítido e fácil reconhecer o parâmetro intensidade - basta ouvir uma vez para identificar. Pedimos, então, para que escutassem e percebessem onde estavam as partes fortes e fracas e, após, representassem com a movimentação do corpo de maneira livre na sala e, quando identificassem o momento de grande intensidade na música, os alunos deveriam parar os movimentos e ficar em posição de estátua; quando acontecer novamente o ataque intenso da música, todos voltariam a se movimentar.

No primeiro momento, notamos que os alunos ficaram um pouco encabulados e se movimentavam muito pouco sendo preciso que nós participássemos da atividade, propondo movimentos e os estimulando, o que funcionou, pois soltaram-se; de maneira bastante satisfatória, perceberam os sons fortes e fracos.

A audição musical atenta deve ser prioridade nas atividades musicais. Segundo o pesquisador e educador Keith Swanwick, ouvir ativamente não significa apenas "colocar o órgão auditivo em funcionamento", mas desenvolver a audição nas suas "sutilezas e nos reflexos", já que o exercício da escuta "cria as 
condições necessárias para que a pessoa se torne receptiva ao ambiente sonoro e aprenda a pensar sobre o que ouve". (SWANWICK, apud RODRIGUES, 2015).

Em seguida, partimos para outro exercício, em que trabalhamos o parâmetro sonoro duração e, para tornar mais fácil o entendimento, pedimos a um dos alunos que fizesse o exercício com o professor, enquanto os outros observavam: a atividade deveria ser feita em dupla, com o objetivo de identificar os tempos e a duração dos sons, e consistia em usar as mãos batendo as palmas de suas mãos com as mãos da sua dupla, e fazer movimentos circulares com as mãos, conformes as regras estabelecidas.

De maneira geral, notamos que os alunos tiveram bastante interesse em fazer os exercícios e percebemos que o conteúdo foi bem-assimilado, e as atividades conseguiram atingir seus objetivos. Mais uma vez, compreende-se que, visualizando através do corpo e de suas expressões, os conteúdos musicais se tornam mais perceptíveis e aumenta a capacidade de entendimento por parte dos alunos.

Por fim, foi demonstrado no quadro como esses movimentos são representados pela escrita musical, utilizando os símbolos e as figuras de som que fazem parte do vocabulário comum da teoria musical.

\section{Aulas sobre parâmetros do som - timbre e altura}

Após debate em reunião, os bolsistas decidiram que a atividade que poderia exemplificar os parâmetros do som timbre e intensidade seria a brincadeira chamada "Seven", na qual os alunos executam sete ostinatos rítmicos (séries de movimentos repetidos), aumentando gradativamente o seu grau de complexidade. Essa atividade utiliza o corpo e a classe (mesa) de aula, como elementos sonoros, e foi proposta visando a que os estudantes do Ensino Normal pudessem executá-la, quando entrassem em sala de aula com seus futuros alunos, visto que não necessita de equipamentos e instrumentos musicais para ser realizada.

No início da atividade, pedimos para os alunos prestarem muita atenção, pois seriam ouvidos sete sons produzidos por um dos bolsistas, usando a mesa e o corpo como recurso sonoro. Após a escuta, os alunos deram um relato sobre esta experiência de escuta, colocando quais seriam os sons que foram 
produzidos e como eles entendiam que tais sons teriam sido executados. Durante o debate, notamos algumas dificuldades na assimilação do som, mas, no geral, as estudantes conseguiram diferenciar os timbres com facilidade.

Após uma breve explicação sobre o parâmetro timbre, explicamos passo a passo como seria a brincadeira Seven, mostrando como seriam feitas as sete sequências rítmicas (ostinatos) e sua devida movimentação.

Para auxiliar a execução da atividade, os bolsistas criaram uma partitura de forma analógica - uma representação gráfica dos sons que utiliza símbolos, que não os da teoria musical - e colocaram no quadro para melhor visualização dos movimentos e facilitar o processo de internalização da brincadeira rítmica, visto que a educação musical pode valer-se de disposição para uma representação gráfica, desde os primeiros momentos, que auxilia no processo de percepção musical, fazendo com que a matéria-prima tão abstrata da música (o som) se torne algo mais concreto. Para França (FrançA, 2010, p. 10), "registrar é uma forma de se materializar e organizar o complexo processo da percepção musical".

Inicialmente, os alunos não encontraram dificuldade para a execução dos ostinatos; entretanto, a manutenção do pulso (velocidade) foi um problema encontrado. Para que o andamento da brincadeira não acelerasse, foi necessário que a contagem feita pelos bolsistas continuasse em voz alta, pois, com a execução do movimento se dando de forma fluida, a turma alterava o andamento da brincadeira, fazendo com que, no seu término, estivessem todas em uma velocidade maior do que quando foi iniciado.

No término da aula, os bolsistas reforçaram a ideia de timbre utilizando outro parâmetro: a altura. Mostrando notas graves e agudas com a voz e com o corpo (percussão corporal), foi reforçada a ideia sobre tais parâmetros, finalizando assim as atividades.

$\mathrm{Na}$ aula seguinte, foram revisados os conceitos trabalhados e proposto que os alunos criassem novas sequências rítmicas. Além da audição e da prática, a composição é um dos pilares da educação musical, segundo Swanwick. Propusemos, então, que fizessem uma composição seguindo os critérios utilizados de movimentos rítmicos e de registro com a chamada partitura analógica. Um aspecto interessante desse momento foi a composição influenciada pela estética dos símbolos escolhidos para a partitura analógica: os 
alunos montaram sequências de figuras, sem antes pensar no som que geraria a ordem. Em seguida, foi feita a execução da composição das turmas e foi explicado mais a fundo sobre figuras rítmicas, usando a escrita alternativa.

Nossa avaliação foi de que as quatro turmas com as quais trabalhamos realizaram todas as atividades propostas e reagiram positivamente, demonstrando interatividade, trabalho em grupo e interesse.

\section{Considerações finais}

Sendo as turmas de magistério da escola Cristóvão de Mendoza constituídas tanto por alunos com alguma experiência na prática docente quanto por outros que ainda não atuam como professores e estão focados na conclusão dos estudos e ainda sem perspectiva de utilizar os aprendizados futuramente, pôde-se perceber que o desenvolvimento do trabalho ocorreu de forma distinta em cada um dos casos. Em algumas turmas, notamos um interesse elevado nos conteúdos aplicados; recebemos um feedback de alunos relatando como já estavam se adaptando aos conteúdos aprendidos e os utilizando em suas aulas, na Educação Infantil. Em outras turmas percebemos surgir gradativamente o interesse pelo conteúdo música e pelas atividades propostas.

Para nós é um grande desafio a experiência de ensinar, pensando na maneira como eles poderão adaptar as práticas de ensino e de vivência musical em futuros planejamentos de aula. O ensino musical é tão vivo quanto a própria música, e sua pedagogia é necessariamente ativa. Se, por um lado, temos os alunos que precisam aprender os conceitos elementares da música, a partir de uma experiência real, por outro lado encontramos os mesmos estudantes preparando-se para entrar na sala de aula e planejando suas ações com o que transmitimos. Com isso, é evidente a atenção que devemos ter na hora de aplicar as atividades propostas, dando a devida atenção para auxiliar, estimular e esclarecer dúvidas sobre como trabalhar com música em sala de aula.

Em um panorama geral, ainda temos bastante trabalho a fazer, porém conseguimos ver alguns avanços de quando chegamos para aplicar a primeira aula, à medida que se tornaram mais fluidas e de melhor aproveitamento, tanto para os estudantes quanto para nós os professores. Gradativamente, estamos melhorando a forma como nos relacionamos com as turmas, descobrindo os 
meios mais produtivos de conduzir as aulas e ajustando nossas práticas como percebemos a realidade dos nossos alunos.

\section{Referências}

AZEVEDO, Maria Cristina de Carvalho Cascelli; GROSSI, Cristina; MONTANDON, Maria Isabel. Formatos alternativos para a prática de ensino em música: a experiência da Universidade de Brasília. In: MATEIRO, Teresa; SOUZA, Jusamara (Org.). Práticas de ensinar música: legislação, planejamento, observação, registro, orientação, espaços e formação. Porto Alegre: Sulina, 2008.

FIGUEIREDO, Sérgio Luiz Ferreira. A educação musical no século XX: métodos tradicionais. Disponível em:

<http://www.amusicanaescola.com.br/pdf/Sergio_Luiz_Figueiredo.pdf >. Acesso em: 3 ago. 2017.

FRANÇA, Cecília Cavalcante. (Des)construindo a forma musical. Disponível em: <http://www.abemeducacaomusical.com.br/revista_musica/pdfs/revista_musica_educa cao_basica2.pdf>. Acesso em: 15 nov. 2017.

GAINZA, Violeta Hemsy de. Estudos de pedagogia musical. São Paulo: Summus, 1988.

JEANDOT, Nicole. Explorando o universo da música. São Paulo: Scipione, 1990.

MATEIRO, Teresa; ILARI, Beatriz (Org.). Pedagogias em educação musical. Curitiba: Intersaberes, 2012. E-book. Disponível em:

$<$ https://ucs.bv3.digitalpages.com.br/users/publications/9788565704397/pages/13>.

RODRIGUES, Matheus Almeida; SWANWICK, Keith. Ensinando música musicalmente.

Arquivo Brasileiro de Educação, Belo Horizonte, v. 3, n. 5, jan./jul. 2015. Disponível em: $<$ http://periodicos.pucminas.br/index.php/arquivobrasileiroeducacao/article/view/1085 9/9315>. Acesso em: out. 2017.

SCHÖN, Donald A. Educando o profissional reflexivo: um novo design para o ensino e a aprendizagem. Porto Alegre: Artmed, 2000.

SOUZA, Jusamara. Aprender e ensinar música no cotidiano. Porto Alegre: Sulina, 2012.

SWANWICK, Keith. Ensinando música musicalmente. São Paulo: Moderna, 2003.

BLOG DO subprojeto Música do Pibid-UCS: <http://pibid-ucs-musica.blogspot.com.br>. 


\title{
CONTRIBUIÇÕES DA ARTE NO AMBIENTE ESCOLAR
}

\author{
Laura Smiderle \\ laura_smiderle@hotmail.com \\ Ana Felisberto \\ aefelisberto@gmail.com \\ Subprojeto Artes Plásticas e Visuais \\ Escola Municipal de Ensino Fundamental Santa Corona
}

Neste resumo, busca-se sintetizar as experiências vivenciadas e o resultado das pesquisas desenvolvidas na Escola Municipal de Ensino Fundamental Santa Corona, localizada em Caxias do Sul, RS, em 2017, pelas acadêmicas do curso de Licenciatura em Artes Visuais da Universidade de Caxias do Sul - participantes do subprojeto Artes Plásticas e Visuais /Pibid-UCS.

No início de 2017, foram percebidas mudanças no comportamento e pensamento dos 9os anos (atendidos pelo Pibid desde o ano anterior), que deixaram de participar e se interessar pelas aulas, demonstrando gradualmente, no decorrer do projeto, desvalorização pelas aulas, principalmente aquelas que envolviam exercício mental, como as expositivo-dialogadas e as de leituras de imagens. Em contrapartida, atividades puramente manuais agradavam e satisfaziam a turma. Esse pensamento foi explicitado primeiramente pelos alunos, que, posteriormente, foram apoiados por seus pais. A justificativa dada por eles ao seu pensamento é que a Arte é menos importante que os demais componentes curriculares e, por isso, deve ser menos complexa e trabalhosa, deixando assim os alunos descompromissados para dedicar seu tempo em outras disciplinas julgadas mais importantes. A partir desse pensamento e questionamento, surgiu a necessidade de se discutir o espaço da Arte na sociedade.

Depois dessa situação, iniciou-se uma pesquisa visando a perceber como a arte é compreendida pela comunidade escolar, através de dois questionários um aplicado com os alunos e outro com a comunidade escolar (professores, funcionários, diretores, etc.), a fim de "ter como referência a realidade do aluno, o mundo que o cerca, seus interesses, para estimular a ampliação de sua visão

\footnotetext{
* Coordenadora do subprojeto: Profa. Dra. Maria Helena Wagner Rossi. Supervisora: Profa. Raquel Longui.
} 
de mundo, sua capacidade de compreender a realidade e situar-se nela". (GOMIDE, 2013, p. 2).

Percebemos que os alunos não visitam espaços culturais com freqüência; a maior parte frequenta museus e exposições apenas em excursões e passeios oferecidos pela escola. Sendo assim, o principal vínculo entre os estudantes e a Arte é a escola, que normalmente não possui subsídios para ampliar a relação entre os estudantes e as manifestações de arte expostas na cidade. Isso quer dizer que os alunos terão pouco acesso a espaços culturais fora da escola e da sala de aula, uma vez que o acesso a espaços culturais fica sob a responsabilidade quase que unicamente da família do aluno. Esta, na maior parte das vezes, não costuma valorizar a Arte ou frequentar esses espaços.

Apesar da desvalorização, percebemos que, mesmo assim, existem muitas aberturas por parte da escola para inserir a Arte ativamente em seu espaço, como cartazes, murais, decoração das festas e eventos escolares, feiras de talentos, etc. Essas atividades que, a princípio, têm cunho estético e decorativo, podem também ser repensadas para além de enfeitar a escola, para promover o pensamento em Arte. Para tanto, foram aproveitadas e remodeladas as aberturas para a Arte existentes na escola, ampliando-as gradualmente com o apoio da equipe diretiva. Começamos então a pensar em atividades em que a Arte fosse exposta no ambiente escolar, como provocadora de discussão e de contextualização de conteúdos.

O trabalho da diretoria, juntamente com a dos professores, é essencial para a gestão que procura proporcionar a formação de indivíduos preparados para viverem nesta sociedade. Esses indivíduos precisam construir sua autonomia, aprender a ter responsabilidades para resolver problemas, ter consciência de seus direitos e deveres e também desenvolver a capacidade crítica de pensamento. Tudo isso pode ser atribuído à ciência, à cultura e inclusive à arte.

Para que as interações com a arte fossem mais significativas, as exposições na escola eram pensadas e desenvolvidas pelos alunos, o que fazia com que questionamentos sobre o espaço da Arte, em sua vida e na comunidade escolar, fossem repensados, uma vez que, ao intervir ativamente na escola, o estudante coloca-se em posição atuante e integradora. 
Ao montar as exposições de seus trabalhos de criação e intervenção artística, os alunos se depararam com questionamentos, como, por exemplo: Quais são os espaços mais adequados para expor seus trabalhos? Quais seriam as ações e reações do restante da comunidade escolar sobre elas? A partir das percepções sobre o respeito (ou falta dele) às suas produções, houve necessidade de repensar o valor da arte nos diferentes espaços de exposição. Exposição de arte na escola, por exemplo, produz experiências estéticas que podem proporcionar novas maneiras de perceber o mundo e o próprio cenário escolar.

Percebemos que, ao adotarmos essas medidas, mudanças começaram a acontecer na escola. Os murais, que normalmente ficavam vazios, agora, quando não estavam sendo ocupados com trabalhos do componente curricular Arte, eram utilizados por outros professores em suas disciplinas. Não só os murais, como todo o ambiente escolar passou a receber mais intervenções da comunidade escolar. Com isso, constatamos que houve um aumento da valorização não só da disciplina Arte, mas também da escola, como um patrimônio, aumentando os vínculos de pertencimento dos estudantes com a escola.

A valorização dos alunos pelas exposições de trabalhos é muito significativa para eles, pois percebem a importância que atribuímos às suas produções. Nesse período de exposições, todos os que frequentam a escola têm a oportunidade de estar em contato com a Arte, e isso enriquece a vivência dentro da escola. Concluímos que o projeto promoveu incentivo para que os alunos sigam se empenhando na elaboração de trabalhos criativos.

Palavras-chave: Ensino de arte. Valorização da produção artística na escola. Exposição de arte na escola.

\section{Referências}

GOMIDE, Cristina H. Fundamentos e metodologia de ciências humanas e o tempo histórico como uma das categorias fundamentais na experiência docente. In: SEMINÁRIO NACIONAL DE HISTÓRIA, 27., 2013, Natal. Anais... Natal, 2013. 


\title{
COR E FORMA NAS AULAS DE ARTE DO ENSINO FUNDAMENTAL
}

\author{
Carina Pasqual \\ capasqualfotografias@gmail.com \\ Subprojeto Artes Visuais \\ Escola Municipal de Ensino Fundamental Santa Corona
}

Este resumo apresenta e comenta um projeto desenvolvido na EMEF Santa Corona, em Caxias do Sul (RS) no decorrer do primeiro semestre de 2017, no subprojeto Artes Visuais do Pibid/da Universidade de Caxias do Sul.

O projeto foi desenvolvido em turmas de 8 o ano do Ensino Fundamental, tendo como motivação a pouca familiaridade dos estudantes com os conceitos básicos relacionados à teoria da cor. Durante o período de observação das turmas de 8ㅇ ano, a professora titular abordou os conteúdos: cor, tempo e espaço, relembrando os estudantes sobre as cores primárias e as possibilidades de cores, que podem surgir com mistura destas. Com surpresa, notou-se que os alunos apresentaram dificuldades no entendimento dos processos de geração de cores. Um breve diagnóstico com as turmas evidenciou interesse e curiosidade relacionados ao assunto "cor na Arte". Assim, o estudo da cor e da forma foi eleito como tema para o projeto. Meira fundamenta a justificativa do projeto, ao dizer:

As linguagens artísticas são fontes ricas de apreensão e compreensão da realidade. A arte representa, na educação, um fator de identidade e de simbolização do desejo, bem como de conhecimento e leitura de códigos e símbolos que o imaginário social revela. (MEIRA, 1995. p. 21).

A proposta foi desenvolver os conteúdos "cor e forma", a partir do estudo dos conceitos básicos da teoria da cor, relacionando a teoria e a prática, visando que, ao longo do processo, os estudantes ampliassem seu entendimento sobre as cores, como, por exemplo: como se formam; em que contextos podem ser utilizadas; que sensações podem nos transmitir.

\footnotetext{
* Coordenadora do Subprojeto: Profa. Dra. Maria Helena Wagner Rossi. Supervisora: Profa. Raquel Longui.
} 
Para a realização do projeto, inicialmente fez-se uma contextualização sobre a teoria da cor, utilizando imagens fixas e vídeos. Em seguida, os alunos confeccionaram um círculo cromático, utilizando as cores primárias. Produziram cores secundárias e terciárias, com o objetivo de experimentar, transformar cores e analisar os processos de composição.

Em um segundo momento, após a abordagem do tema "cores quentes e cores frias" - analisando como Mondrian, Kandinsky e Van Gogh usavam a cor e a forma -, os alunos receberam reproduções em preto e branco de duas imagens: "O Grito" de Edvard Munch e "The Bird", imagem do livro de colorir Floresta Encantada. O primeiro deveria ser colorido apenas com cores quentes e o segundo deveria receber cores frias. O objetivo foi observar e analisar a mistura e a aplicação das cores quentes e frias. Posteriormente, realizou-se uma contextualização sobre o conceito de forma, abordando as seguintes características: definição, contorno, silhueta, figura versus fundo, suportes, formas figurativas, abstratas e geométricas, bem como o Tangram e suas sete peças.

Para estudar a cor e a forma, cada aluno recebeu quatro cópias em papel das peças de um Tangram devendo construir, com elas, os seguintes itens: 1) a inicial do nome com as cores primárias; 2) uma figura humana com cores frias; 3 ) um objeto utilizando cores quentes; 4) um animal utilizando cores terciárias. No processo de tentativa e erro, os alunos foram estimulados a: observar a formação das cores; experimentar quantidades e misturas diferentes de tinta e suas possibilidades; comparar essas possibilidades de variação de tonalidades e decidir qual das misturas apresentava-se mais adequada para atender às solicitações de cada atividade proposta.

Como trabalho final, cada aluno pôde escolher entre algumas opções de obras de arte para recriá-las, restringindo-se, no entanto, às cores primárias, o preto e o branco. Os trabalhos foram expostos em um mural, apresentando-os à comunidade escolar. Os trabalhos mostraram uma nova compreensão sobre os conceitos estudados, confirmando o que diz Rossi sobre a compreensão do elemento cor na arte: a partir da adolescência, os alunos admitem que a alteração no uso das cores, em uma obra, altera o seu sentido. Diz a autora: “Entre os adolescentes aparece a noção de que a cor é constitutiva da imagem, 
isto é, se as cores forem trocadas por outras, a imagem teria outro sentido. (ROSSI, 2011, p. 72).

O projeto buscou aprimorar os conhecimentos básicos de arte. Acredita-se que houve condições para uma aprendizagem significativa. Por meio de uma revisão de conceitos, notou-se o gradativo amadurecimento dos alunos, conforme cada assunto era abordado.

O projeto teve a preocupação de que as atividades propostas fizessem sentido e permitissem aos alunos a expressão e comunicação por meio da arte, reconhecendo-a como modo de conhecimento.

Palavras-chave: Arte-educação. Cores. Formas. Experimentação. Aprendizagem significativa.

\section{Referências}

MEIRA, Marly Ribeiro. Construindo trajetórias. Projeto Melhoria da Qualidade de Ensino/Educação Artística. Governo do Estado do Rio Grande do Sul/Secretaria da Educação, 1995.

ROSSI, Maria Helena Wagner. Imagens que falam: leitura de arte na escola. 5. ed. Porto Alegre: Mediação, 2011. 


\title{
Ciências Biológicas e Matemática
}

\section{1 \\ AÇÕES COLABORATIVAS NO ENSINO E NA APRENDIZAGEM DE MATEMÁTICA}

\author{
Leonise Maria Facchin \\ leo_nise@hotmail.com \\ Suélen Cristina dos Santos \\ scsantos7@ucs.br \\ Subprojeto Matemática* \\ Escola Estadual de Ensino Médio São Caetano
}

Resumo: O presente trabalho relata ações colaborativas no ensino e na aprendizagem de Matemática, desenvolvidas pelo Programa Institucional de Bolsas de Iniciação à Docência (Pibid), da Universidade de Caxias do Sul (UCS), com o subprojeto dessa área, da Escola Estadual de Ensino Médio São Caetano. Como foco principal, está a gincana desenvolvida no dia 14 de julho de 2018, que obteve como resultado grande envolvimento, diversão e consolidação de conhecimentos matemáticos.

Palavras-chave: Matemática. Gincana. Aprendizagem. Pibid.

\section{Introdução}

A Matemática nem sempre é vista com agrado pelos estudantes da Educação Básica. No Ensino Médio, com o nível de complexidade crescendo, geralmente, o afastamento é mais latente. A maioria dos professores, então, busca alternativas e, uma estratégia plausível, são atividades nas quais o grupo em que está inserido seja todo mobilizado.

O Pibid-UCS Matemática, da Escola Estadual de Ensino Médio São Caetano, elaborou uma gincana, com o objetivo de proporcionar atividades que fizessem com que a colaboração para completar as tarefas trouxesse, em primeiro momento, o interesse pela Matemática e, desse modo, a consolidação de aprendizagens.

\footnotetext{
${ }^{*}$ Coordenadora do subprojeto: Profa. Me. Ana Cristina Possapp Cesa. Supervisora: Profa. Leonise Maria Facchini.
} 


\section{Referencial teórico}

O ato de ensinar nem sempre é fácil. Ensinar Matemática tampouco. Para contornar essa situação, podem-se criar planejamentos que insiram o estudante e o tornem ativo. Ou, ainda, ações em que ele necessite da ajuda dos colegas, e os colegas da colaboração deles, para realizar atividades que levem ao saber.

\footnotetext{
Em situações de cooperação - aqui entendida como co-operar, operar junto, negociar para chegar a algum acordo que pareça adequado a todos os envolvidos -, a obrigação é considerar todos os pontos de vista, ser coerente, racional, justificar as próprias conclusões e ouvir o outro. É nesse processo que se dá a negociação de significados e que estabelece a possibilidade de novas aprendizagens. (SMOLE, 2008, p. 11).
}

Uma gincana é uma atividade que "envolve uma série de jogos onde se testa habilidades dos participantes na busca de soluções, cujo objetivo é aumentar o conhecimento de um grupo de pessoas de uma forma lúdica e dinâmica". (CRUL, 2014, p. 1244). Se bem desenvolvida, promove a situação de colaboração citada por Smole (2008), que, segundo ela, leva à aprendizagem. Desta forma, podemos afirmar que a gincana é uma ação colaborativa.

\footnotetext{
Na colaboração, por outro lado, ao trabalharem juntos, os membros de um grupo se apoiam, visando atingir objetivos comuns negociados pelo coletivo, estabelecendo relações que tendem à não-hierarquização, liderança compartilhada, confiança mútua e co-responsabilidade pela condução das ações. (DAMIANI, 2008, p. 213).
}

As tarefas propostas envolvem toda a turma, mesmo os que, na maioria das aulas, não demonstram interesse. Nesses momentos aparecem lideranças, soluções inovadoras e, principalmente, momentos de associação, reflexão e compreensão de conceitos que, muitas vezes, antes, não estavam consolidados. Já que "[...] uma Gincana Matemática consiste em um conjunto de atividades que tem como objetivo principal revisar conceitos matemáticos já vistos em sala de aula de uma maneira mais divertida, promovendo a interação entre alunos das diversas séries [...]". (CRUL, 2014, p. 1244). 


\section{Descrição da atividade desenvolvida}

O grupo do Pibid-UCS Matemática desenvolveu diversas atividades ao longo do período em que esteve presente na escola. Com o tempo, notou-se que quanto mais interação houvesse entre os colegas, maior era o entusiasmo e o retorno positivo da atividade.

Partindo dessa constatação, o grupo organizou uma gincana que envolvia todas as turmas do turno de Ensino Médio da manhã: quatro $1{ }^{\circ} \mathrm{s}$ anos, três $2{ }^{\circ} \mathrm{s}$ anos e dois 3ㅇs anos. Os objetivos principais eram demonstrar que a Matemática pode ser divertida e acessível e ensinar aprender de maneira lúdica e com bons resultados.

Cada turma formava uma equipe e escolhiam um líder e, durante o passar da manhã, tinham tarefas a cumprir, algumas concomitantes, que valiam pontos. A eles cabiam as responsabilidades de: entregar no horário o que foi solicitado; manter a equipe identificada e não sair da sala respectiva sem autorização.

Uma das tarefas consistia em dar nome à equipe e criar-lhe um logotipo.

Figura 1 - Bolsistas do Pibid/UCS mostrando os cartazes confeccionados pelos alunos da EEE Médio São Caetano, referentes ao logotipo das equipes

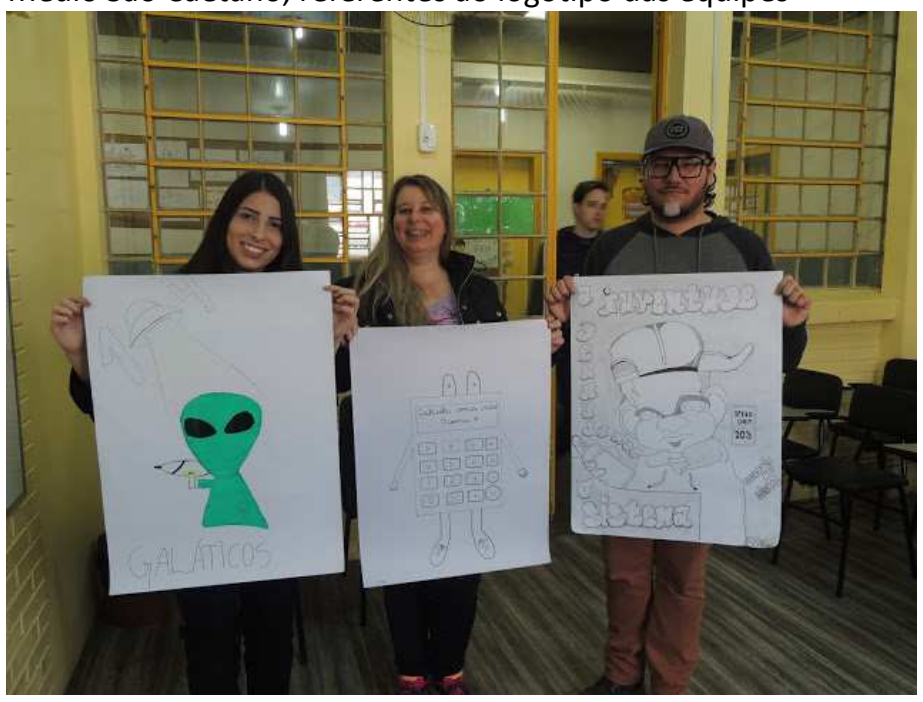

Fonte: Equipe Pibid-UCS Matemática.

Diversas provas que relacionavam matemática e o cotidiano foram aplicadas, sendo que a última consistia em uma paródia que devia contemplar 
algum conteúdo já estudado de Matemática e, após, deu-se então o resultado da gincana.

A equipe vencedora foi a turma do segundo ano do Ensino Médio e, como prêmio, receberam sacos de bombons.

\section{Período de realização da atividade}

A gincana foi realizada no dia 14 de julho de 2017, no turno da manhã. A data foi escolhida por estar próxima às férias de inverno, época em que os educandos geralmente estão mais desinteressados das aulas regulares.

\section{Considerações finais}

Todas as ações propostas ao logo dos anos pelo Pibid-UCS Matemática surtiram efeito muito positivo nos educandos que participaram. Eles se mostravam mais entusiasmados e questionavam sobre quando seria a próxima atividade da qual o grupo iria participar.

O êxito desse trabalho deve-se muito à cooperação que é necessária entre os participantes, tanto do grupo de bolsistas, quanto dos estudantes que participaram. Por conta disso, podemos constatar que ações colaborativas, como a gincana, são eficazes no ensino e na aprendizagem de Matemática.

A gincana foi muito bem-recebida pelos estudantes. Trouxe oportunidades de consolidação de conhecimentos, momentos de diversão e, sobretudo, mostrou que o estudo da Matemática de maneira prazerosa é possível, quando todos estão inseridos no processo.

\section{Referências}

CRUL, Giovanni Antonio Cereta et al. Gincana matemática. Paraná: 2014. Disponível em: <https://dspace.unila.edu.br/bitstream/handle/123456789/2838/PIBID1\%2C12441248. pdf?sequence=1\&isAllowed=y>. Acesso em: fev. 2018.

DAMIANI, Magda Floriana. Entendendo o trabalho colaborativo em educação e revelando seus benefícios. Curitiba: 2008. Disponível em:

<http://www.scielo.br/pdf/er/n31/n31a13>. Acesso em: fev. 2018.

SMOLE, Kátia Stocco et al. Jogos de matemática: de $1^{\circ}$ a $3^{\circ}$ anos. Porto Alegre: Artmed, 2008. 


\title{
22
}

\section{ATUAÇÃO DO PIBID-BIOLOGIA/UCS NA ESCOLA ESTADUAL IRMÃO GUERINI}

\author{
Angélica Ferrari Rodrigues* \\ profe.angelica.bio@gmail.com \\ Meliny Dalla Bona Gallio** \\ melinydbgallio@gmail.com \\ Andreia Won Miller ${ }^{* *}$ \\ andreiawonmuller2013@gmail.com \\ Gabriela Rodrigues Alves** \\ gralves@ucs.br \\ Gustavo Blanco Correa** \\ gbcorrea2@ucs.br \\ Josiana Pasa Zampieri** \\ jpasazampieri@gmail.com \\ Dr. Wilson Sampaio de Azevedo Filho ${ }^{* * *}$ \\ wsafilho@ucs.br \\ Subprojeto Pibid - Biologia/UCS - Campus-sede \\ Escola Estadual de Ensino Médio Irmão Guerini
}

\section{Introdução}

As dificuldades encontradas em sala de aula pelos docentes são inúmeras no Brasil. Para o desenvolvimento do processo de ensino e aprendizagem, são necessárias aulas organizadas e diversificadas que despertem a atenção dos estudantes, incentivando-os à busca do conhecimento científico e ao desejo de aprender. Assim, é fundamental criar novas metodologias e estratégias para permitir uma educação adequada nas escolas. Nesse processo, é relevante ressaltar a importância das atividades práticas, que ganham destaque dados seus bons resultados de aproveitamento.

O Programa Institucional de Bolsa de Iniciação à Docência (Pibid/Capes) faz parte da implementação de um ensino com qualidade e da formação de professores para a Educação Básica, inserindo o licenciando no cotidiano de escolas da rede pública. O programa tem beneficiado os educandos nas escolas e os bolsistas, que aprofundam o conhecimento adquirido na universidade.

\footnotetext{
* Supervisora Profa. Angélica Ferrari Rodriques.

** Bolsistas Pibid-UCS.

*** Coordenador Prof. Dr. Wilson Sampaio de Azevedo Filho
} 


\section{Objetivos}

- avaliar as atividades desenvolvidas pelo Pibid-Biologia/UCS, na Escola Estadual de Ensino Médio Irmão Guerini;

- verificar a contribuição das práticas aplicadas pelo Pibid no processo de ensino e aprendizagem.

\section{Referencial teórico}

No Brasil, há necessidade de formar professores que estejam aptos para enfrentar os novos desafios dos ambientes escolares, onde o público nestes inseridos está em busca de uma aprendizagem significativa. Para sanar tais necessidades, existem ações que ajudam esses profissionais, ainda na graduação, a conhecerem melhor o ambiente escolar.

Segundo o Ministério da Educação, o Pibid é um programa que visa à valorização e ao incentivo à formação do professor para o ensino no País. (BRASIL, 2017).

O Pibid, para os acadêmicos, é uma grande oportunidade para conhecer melhor o contexto escolar e como é o cotidiano dentro e fora da sala de aula, além de proporcionar uma visão diferenciada sobre a educação no Brasil. O Pibid é uma oportunidade de entrar em contato com a realidade das escolas. (STENTZLER, 2013).

Para ser um professor é necessário ter planejamento, sensibilidade e disciplina, pois o docente é apenas o mediador do conhecimento e proporcionará, por meio de diversas atividades, a construção do mesmo aos discentes. A presente constatação vem ao encontro do método de ensino de Freire (2017, p. 58), que afirma que, quando o professor media o conhecimento, ele promove nos discentes sua autonomia diante das diversas situações. E essa é a essência do programa.

\section{Período de realização da atividade de referência do relato}

O questionário de avaliação para o diagnóstico da contribuição do PibidBiologia/UCS foi aplicado, ao longo do mês de outubro de 2017, para os alunos 
das três turmas de Ensino Médio da Escola Irmão Guerini. As turmas escolhidas para as análises estiveram evolvidas nas atividades práticas do Pibid no ano de 2015 a 2017.

\section{Metodologia e resultados}

O trabalho foi realizado com o auxílio da internet em uma rede social, recurso muito utilizado atualmente; foi disponibilizado um questionário composto de quatro questões, nas quais os estudantes forneciam suas opiniões, facilitando, assim, a posterior análise.

Diante disso, é possível verificar, na Figura 1, os resultados da primeira questão referente à avaliação do planejamento das atividades do Pibid para que ocorra aprendizado nos estudantes.

Figura 1 - Avaliação do planejamento das atividades do Pibid para o aprendizado do aluno

$$
\square \text { Insatisfatório } \square \text { Indiferente } \square \text { Bom } \square \text { Muito Satisfatório }
$$

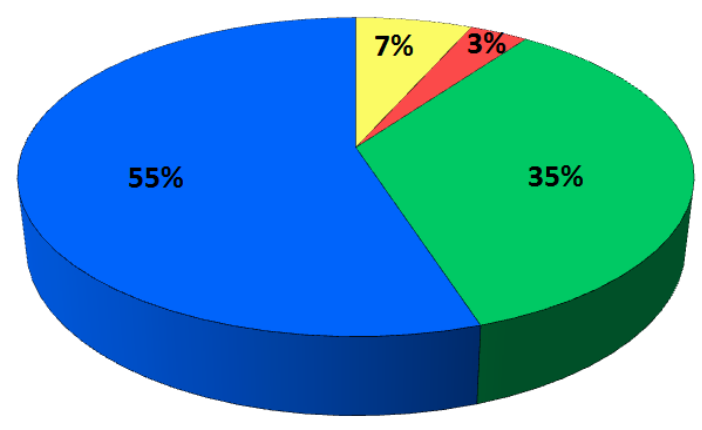

Os resultados obtidos demonstram que, para $55 \%$ dos discentes, as atividades são muito satisfatórias para que ocorra a aprendizagem, pois, com propostas alternativas e dinâmicas, a aprendizagem torna-se mais fácil.

A segunda questão que abordava a opinião dos estudantes sobre as atividades do Pibid tornarem o estudo da Biologia mais interessante, obteve resultados significativos, conforme demonstra a Figura 2. 
Figura 2 - Opinião dos estudantes sobre as atividades do pibid tornarem o estudo da Biologia mais interessante

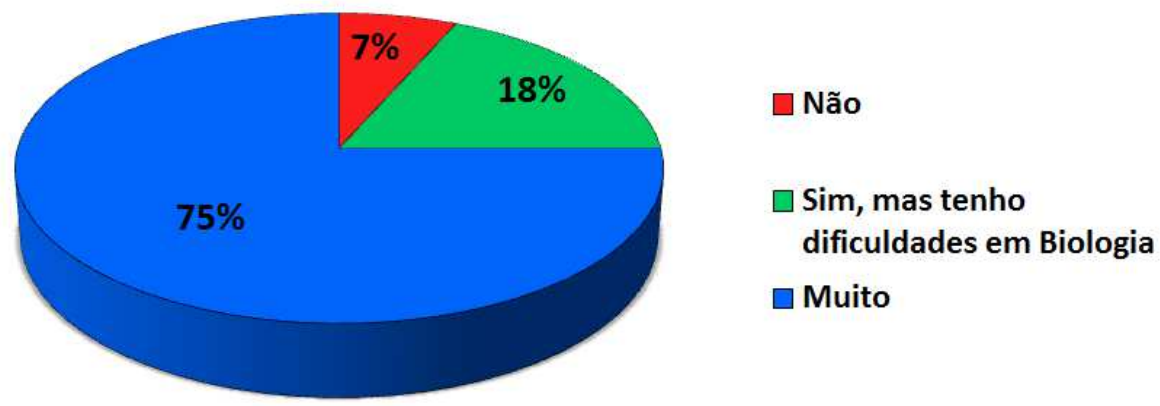

A Figura 2 indica que para 75\% dos entrevistados, os conteúdos de Biologia tornaram-se mais interessantes quando foram realizadas atividades diversificadas pelo Pibid. Assim, levando em conta a heterogeneidade das turmas, os estudantes atuaram como protagonistas no processo de aprendizagem.

A importância das atividades práticas desenvolvidas no auxílio do aprendizado dos conteúdos propostos foi abordada na terceira questão, e seus resultados podem ser observados na Figura 3.

Figura 3 - Opinião dos estudantes sobre a importância das atividades práticas, como auxílio no aprendizado dos conteúdos propostos

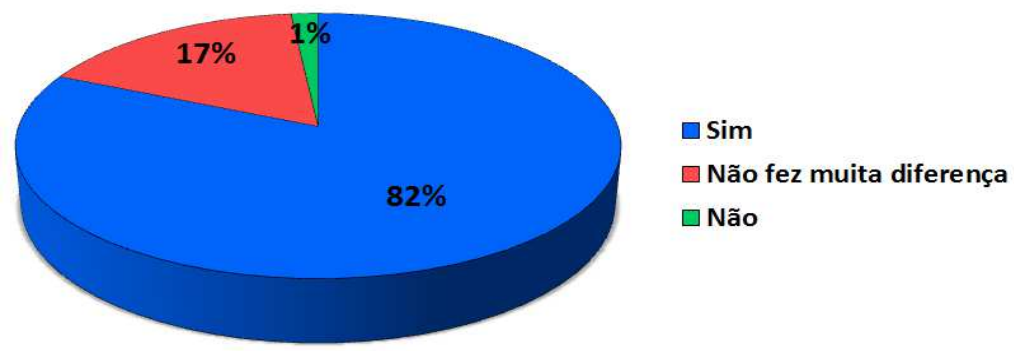

Ao analisar os resultados obtidos, foi constatado que $82 \%$ dos discentes expressaram que as atividades práticas ajudaram a melhor compreensão dos conteúdos trabalhados, auxiliando-os também na realização de suas avaliações, que são essenciais para que tanto discentes como docentes possam mensurar os resultados do processo de ensino e aprendizagem. 
A última questão referente ao interesse dos estudantes em relação às atividades práticas realizadas pelo Pibid foi importante neste estudo. Os resultados demonstraram a heterogeneidade das opiniões dos discentes em relação ao assunto, os quais podem ser verificados na Figura 4.

Figura 4 - Avaliação do interesse do aluno com relação à atividade prática realizada pelo Pibid

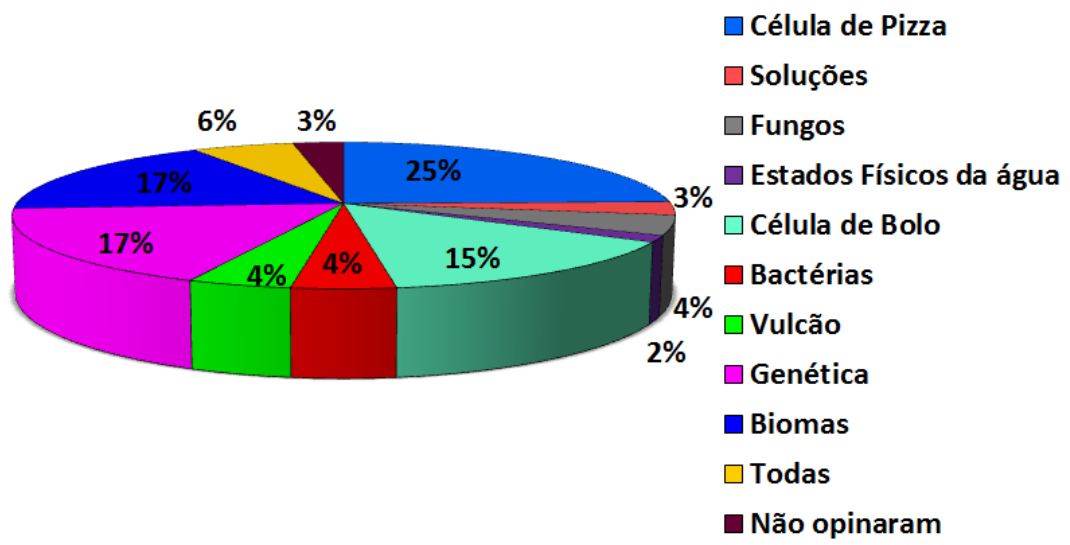

Foram realizadas práticas diversificadas para as diferentes turmas, conforme os assuntos trabalhados. A prática sobre "Célula de Pizza/Bolo", aplicada para os estudantes do 1ㅇ ano, obteve um índice de $40 \%$ de aprovação e satisfação dos estudantes. Para a aprendizagem do conteúdo "Bactérias", com os discentes do 20 ano, apesar do índice de $4 \%$, os estudantes interessaram-se em aprender mais sobre o "mundo microscópico" desses organismos. Para o 3a ano, a prática de "Genética" demonstrou interesse a 17\%, que revelou a importância da mesma na compreensão do conteúdo. Os resultados indicaram que as práticas são importantes, para que os estudantes construam seu conhecimento sobre os conteúdos trabalhados.

\section{Considerações finais}

A contribuição das práticas aplicadas pelos integrantes do Programa Institucional de Bolsa de Iniciação à Docência (Pibid-Biologia/UCS), como auxílio no processo de ensino e aprendizagem, e as atividades desenvolvidas com os discentes da Escola Estadual Irmão Guerini foram significativas. Além de auxiliar 
na construção do conhecimento, as atividades foram planejadas com os docentes e os bolsistas do Pibid, possibilitando troca de ideias, promovendo estratégias de inserção na realidade escolar dos estudantes envolvidos no processo e proporcionando a construção e compreensão dos conteúdos.

Os resultados obtidos demonstram que o programa apresenta grande importância para a aprendizagem dos estudantes do cenário educacional público-brasileiro.

Palavras-chave: Avaliação. Aprendizagem significativa. Atividades experimentais.

\section{Referências}

BRASIL. Ministério da Educação. Programa Institucional de Bolsas de Iniciação à Docência (Pibid). 2017. Disponível em: <http://portal.mec.gov.br/pibid>. Acesso em: 15 out. 2017.

FREIRE, Paulo. Pedagogia da autonomia: saberes necessários à prática educativa. 55. ed. São Paulo: Paz e Terra, 2017.

STENTZLER, Marcia Marlene. O PIBID em minha vida. Paraná: Kaygangue, 2013. 


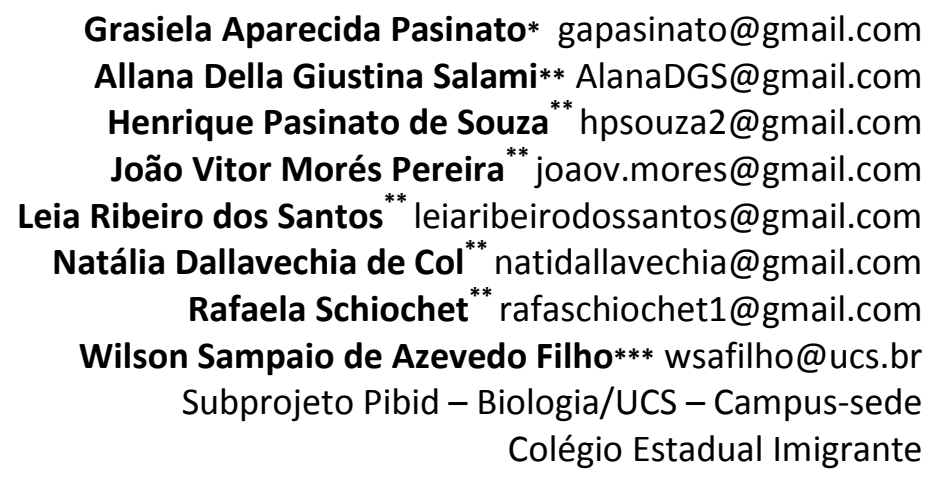

Introdução

A prática docente é permeada por dificuldades que, muitas vezes, estão diretamente relacionadas à baixa qualidade de ensino. Segundo Godefroid (2010), um dos maiores desafios para um professor é manter o entusiasmo do aluno no decorrer da aula. Contudo, diferentes metodologias podem ser utilizadas para cativar o estudante e manter sua atenção, durante as aulas. As atividades práticas com uso de exemplares biológicos, equipamentos de microscopia, jogos relacionados aos conteúdos trabalhados, aulas com materiais diversos e de fácil obtenção, gincanas e produção de modelos didáticos podem ser alternativas na busca de um ensino mais eficaz, atrativo e com melhor qualidade.

O Programa Institucional de Bolsa de Iniciação à Docência (Pibid) é uma iniciativa para o aperfeiçoamento e a valorização da formação de professores para a Educação Básica. O programa tem como objetivo promover a inserção dos graduandos no contexto das escolas públicas, desde o início da sua formação acadêmica, para que desenvolvam atividades didático-pedagógicas, sob a orientação de um docente da licenciatura e de um professor da escola. (BRASIL, 2017). Dessa forma, o Pibid-Biologia/UCS, em parceria com o Colégio Estadual Imigrante, está viabilizando essa iniciativa, juntamente com seis bolsistas

\footnotetext{
* Supervisora Pibid-Biologia/UCS, Colégio Estadual Imigrante.

** Bolsista Pibid-Biologia-UCS.

*** Prof. Dr. Coordenador Pibid-Biologia/UCS.
} 
acadêmicos do curso de Ciências Biológicas, um professor da licenciatura (coordenador de área) e uma professora supervisora.

O Pibid-Biologia/UCS vem atuando no Colégio Estadual Imigrante desde 2014. Todas as atividades propostas e executadas foram elaboradas em conjunto, sempre interligando a teoria com a prática. $\mathrm{O}$ trabalho dos bolsistas do Pibid-Biologia/UCS, no ano de 2017, foi direcionado a quatro turmas de 20 ano do Ensino Médio, totalizando aproximadamente 120 estudantes atendidos pelo programa.

Para que suas abordagens obtenham sucesso, é necessário que o docente identifique e compreenda a percepção de seus educandos sobre sua metodologia utilizada. Para Palma (2005), a verdadeira capacidade de perceber é objetivada, quando tem-se interesse no objeto de percepção, estando este interesse embasado nos próprios conhecimentos de ética, cultura e postura individual, resultando em uma percepção única e diferente de pessoa para pessoa, pelo mesmo objeto. Assim, a percepção analisada neste trabalho é coletiva, uma vez que as respostas codificam esta visão geral e conceitual das abordagens executadas.

\section{Objetivo}

Avaliar o desempenho do Pibid-Biologia/UCS, em seu quarto ano de atuação, e identificar a percepção dos alunos do 20 ano do Ensino Médio, do Colégio Estadual Imigrante, em relação às ações desenvolvidas em 2017.

\section{Período de realização das atividades}

As atividades propostas pela equipe do Pibid-Biologia/UCS foram realizadas no período de março a setembro de 2017.

\section{Metodologia}

O presente estudo foi realizado no Colégio Estadual Imigrante, durante o mês de novembro de 2017, onde foram aplicados 110 questionários de caráter qualiquantitativo, com os alunos do segundo ano do Ensino Médio. 
O questionário utilizado continha oito perguntas, sendo sete objetivas e uma descritiva, na qual os estudantes poderiam incluir sugestões de atividades a serem desenvolvidas. Cada estudante respondeu ao questionário individualmente, mas com possibilidade de discussão em grupos sobre as atividades realizadas pelo Pibid.

\section{Resultado e análises}

Foram realizadas seis atividades práticas envolvendo os temas: importância da classificação dos seres vivos; modelo anatômico de um vírus causador de doença em seres humanos; cultivo de bactérias; jogo sobre as doenças causadas por bactérias em seres humanos; "Colonizando um ambiente" (cujo foco era o estudo dos protozoários) e observação de briófitas. Cada atividade foi desenvolvida após o devido estudo e embasamento teórico sobre o tema, possibilitando aos estudantes relacionarem o conhecimento teórico e prático.

$\mathrm{O}$ resultado obtido na questão número 5 demonstrou que as atividades que mais auxiliaram na aprendizagem foram aquelas em que os estudantes participaram ativamente do processo, como: no cultivo de bactérias (26\%) e construindo um ambiente favorável ao desenvolvimento de protozoários (22\%) (Figura 1).

Figura 1 - Questão 5. Cite as atividades propostas pelos bolsistas Pibid que mais auxiliaram na sua aprendizagem

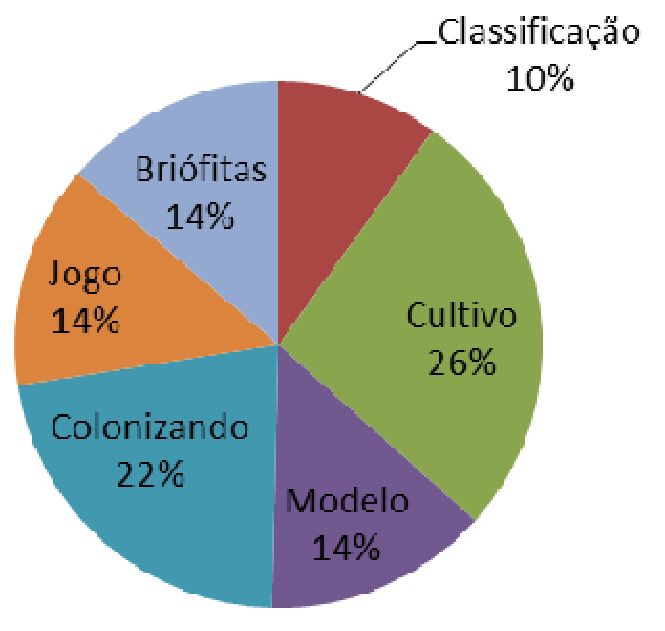


Em uma das questões, os 110 estudantes questionados responderam que estão satisfeitos com as atividades desenvolvidas na disciplina de Biologia, e 87\% acreditam que os conteúdos abordados tornaram-se mais interessantes e compreensíveis, durante as aulas com a atuação do Pibid. As informações obtidas neste estudo reforçam a opinião favorável dos discentes quanto à continuidade do programa no colégio. Foi constatado que $96 \%$ dos alunos da Instituição desejam a permanência do Pibid e a continuidade das atividades no próximo ano.

\section{Considerações finais}

A atuação do Pibid-Biologia/UCS, no Colégio Estadual Imigrante, foi satisfatória e relevante no processo de ensino e aprendizagem. As informações obtidas serão fundamentais para uma atuação mais eficiente do programa na Instituição. Foi possível verificar e refletir sobre as atividades práticas que mais estimularam os estudantes e que, consequentemente, favorecem a participação e a aprendizagem dos discentes. O Programa Institucional de Bolsa de Iniciação à Docência é essencial a boas práticas pedagógicas, dentro e fora das salas de aula, pois promove a troca de experiências entre os docentes e bolsistas, incentivando a busca constante por atividades significativas aos estudantes de Biologia da rede pública de ensino.

Palavras-chave: Docência. Teoria e prática. Qualidade de ensino.

\section{Referências}

BRASIL. Ministério da Educação. Programa Institucional de Bolsas de Iniciação à Docência (Pibid). 2017. Disponível em:<http://portal.mec.gov.br/pibid>. Acesso em: 20 out. 2017.

GODEFROID, Rodrigo Santiago. O ensino de biologia e o cotidiano. São Paulo: Ed. do IBPEX, 2010. v. 1.

PALMA, Ivone Rodrigues. Análise da percepção ambiental como Instrumento ao planejamento da Educação Ambiental. 2005. 83 f. Dissertação (Mestrado) - Curso de Engenharia, Departamento de Programa de Pós-Graduação em Engenharia de Minas, Metalúrgica e de Materiais, Universidade Federal do Rio Grande do Sul, Porto Alegre, 2005. Disponível em: <http://www.lume.ufrgs.br/bitstream/handle/ 10183/7708/000554402.pdf?sequence=1>. Acesso em: 12 out. 2017. 


\title{
DUAS PROPOSTAS PARA USO DE TICS NO ENSINO DE CIÊNCIAS
}

\author{
Aline de Godoy* (a.line.g@hotmail.com); \\ Kétini Baccin*(ketinibaccin@hotmail.com); \\ Willian Lando Czeikoski* (willianlandoc@yahoo.com.br) \\ Igor Pozzebon*' (igorpozzebon2010@gmail.com) \\ Thaisa Dal Pizzol*(thaisadalpizzol04@gmail.com); \\ Profa. Dra. Gladis Franck da Cunha** (gladisfranck@gmail.com); \\ Ariane Pegoraro Nuncio*** \\ Subprojeto Biologia - Carvi \\ EMEF Princesa Isabel - Bento Gonçalves - RS
}

\section{Resumo expandido}

Esse texto tem por finalidade contextualizar e refletir sobre duas experiências de uso do Qrcode, como recurso para ensino de conteúdos de Ciências aos 8 e 6ㅇ anos do Ensino Fundamental, em uma escola pública da rede municipal de Bento Gonçalves, que atende alunos de classes populares.

Cortella (2001) faz uma reflexão sobre o perfil das crianças e dos jovens que, atualmente, frequentam as escolas, as quais assistem, em média, a três horas de TV por dia, desde os 2 anos de idade. Assim, aos 6 anos, quando elas entram no Ensino Fundamental, já assistiram muita coisa e, para essa geração que nasceu inserida em um mundo tecnológico, as metodologias tradicionais, que levam as crianças e jovens a ficarem sentados, em média, 4 horas por dia, "matam" a curiosidade e principalmente o desejo e o amor pela escola.

Quando um educador se apropria das tecnologias de informação e comunicação (TICs), pode utilizá-las no processo de ensino e aprendizagem, para aguçar a curiosidade dos alunos e levá-los em busca de informações mais aprofundadas. Uma destas tecnologias é o QRcode, que consiste em um código visual, que armazena informações, as quais podem ser lidas rapidamente por aplicativos instalados em iphones ou tablets. Este código é bastante utilizado por indústrias, revistas e propagandas, fazendo parte do cotidiano dos alunos e pode cativá-los para a aprendizagem ativa.

\footnotetext{
* Bolsista de Iniciação à docência.

** Coordenadora do subprojeto Pibid-Biologia-Carvi Profa. Dra. Gladis Franck da Cunha.

*** Supervisora do Pibid na EMEF Princesa Isabel.
} 
A utilização desta tecnologia requer um planejamento adequado, pois, segundo Ferreira (1998), a tecnologia por si mesma não é uma cura radical e não vai resolver todos os problemas da escola, mas pode ser uma ferramenta para resolver alguns deles, mas sua aplicação pura e simples não solucionará a maioria destes problemas. Assim, partindo do princípio de que o professor pode utilizar metodologias inovadoras, optou-se por organizar uma sequência didática que levasse em conta a inserção da tecnologia, sem esquecer o contexto escolar e a realidade dos estudantes.

Partiu-se do pressuposto de que a organização de atividades lúdicas, pedagogicamente importantes, com o uso de tecnologias, faz com que a escola se torne um local onde os processos de aprendizagem tenham um salto de qualidade na formação de estudantes reflexivos, preparados para o mercado de trabalho e formadores de opinião. (SAMPAIO; LEITE, 2011). Assim, a partir do sucesso de um projeto desenvolvido em 2015 (Frantz et al., 2016), em que foram atingidos os objetivos de ensino e proporcionadas atividades lúdicas e envolventes, em 2016 utilizou-se, com alunos da EMEF Princesa Isabel de Bento Gonçalves, o Qrcode, como recurso pedagógico com duas turmas de 8o ano para tratar de conteúdos sobre alguns sistemas do corpo humano e com três turmas de 60 ano, com o tema "biomas e espécies em extinção". (NunClo et al., 2017).

Com as turmas de 80 ano, o projeto consistiu em formar grupos para estudar um sistema específico do corpo humano. Assim, cada grupo levantou informações sobre seu respectivo sistema, com a supervisão dos bolsistas, que contribuíram para sanar as dúvidas que surgiam. A seguir, confeccionaram um modelo bidimensional deste sistema em tecido EVA, para ser exposto na escola. Concluída essa construção, com representação de todos os órgãos do sistema, no laboratório de informática da escola, os textos informativos foram transformados em QRcode, utilizando-se um gerador online (http://br.qr-codegenerator.com/). Ao ler estes QRCode, com um aplicativo de celular, os alunos acessavam informações sobre a estrutura e o funcionamento dos órgãos e do sistema como um todo. Além de contribuir para o entendimento de como é produzida esta informação codificada, observou-se empenhou para trazer informações relevantes, ampliando os conteúdos do livro didático, para cativar o interesse da comunidade escolar, já que os modelos em EVA ficaram expostos 
nos corredores da escola, como uma mostra ao alcance de pais, professores, diretores, funcionários e demais alunos.

Nas turmas do 60 ano, o trabalho desenvolvido teve como objetivo valorizar e intensificar o levantamento de informações sobre as principais características dos biomas brasileiros, o conhecimento da biodiversidade e a Educação Ambiental, três turmas de $6^{\circ}$ ano, com alunos entre 11 a 12 anos, totalizando 63 estudantes. Em cada turma, organizaram-se seis grupos, os quais, por sorteio, receberam um bioma cada um. Dessa forma, no total, foram estudados seis biomas (Caatinga, Cerrado, Mata Atlântica, Pantanal, Pampa e Amazônia) e gerados três trabalhos diferentes sobre cada um, uma vez que, após o recebimento de informações gerais sobre cada bioma, os grupos procederam ao levantamento de dados sobre um deles, focando suas buscas em assuntos que despertaram sua curiosidade. O texto elaborado foi transformado em QRCode, para neste formato ser compartilhado em uma mostra sobre os biomas para toda a comunidade escolar.

Os relatos dos alunos do 60 ano resumem que a busca de informações levou-os a conhecerem ambientes e espécies de seres vivos que não imaginavam existir. Em continuidade a esta etapa inicial, em parceria com a professora de Artes, houve o levantamento de informações sobre as espécies ameaçadas de extinção e a confecção de modelos das mesmas, com material alternativo para serem inseridos nas maquetes anteriormente construídas. O compartilhamento com o restante da escola se deu pela exposição das maquetes com os modelos de animais e os respectivos Qrcodes.

Observou-se que a autorização para o uso do celular na escola incentivou a leitura das informações codificadas no formato de QRcode, tanto na mostra sobre o corpo humano quanto sobre os biomas.

Os resultados alcançados sugerem que, embora o celular, notebook e tablet não possam substituir o papel do professor, essas ferramentas e seus aplicativos podem-se, sim, tornar as aulas mais dinâmicas e contar com estudantes mais participativos e motivados. Em especial, na disciplina de ciências, que costuma ser estigmatizada por "ter nomes difíceis", o professor deve buscar diferentes estratégias que se adaptem à realidade dos estudantes, pois são raros os professores que ainda conseguem encantar seus alunos com uma aula totalmente expositiva, utilizando apenas como recurso o quadro e o 
livro didático. Para essa geração, cercada de recursos tecnológicos, é urgente a reformulação do fazer pedagógico, no sentido de utilizá-los como aliados da aprendizagem.

\section{Referências}

CORTELLA, Mário Sérgio. A pata nada, mas será que brinca? Revista Educação, n. 247, nov. 2001. s.p.

FERREIRA, Vítor F. As tecnologias interativas no ensino. Química Nova, v. 21, n. 6, p. 780-786, nov./dez. 1998.

FRANTZ, A. M. F. et al. O uso do QR Code para o ensino de zoologia. In: CONGRESSO DE ZOOLOGIA - O ZOÓLOGO ALÉM DA ACADEMIA, 31., 2016, Cuiabá. Anais... Cuiabá, 2016.

SAMPAIO, Marisa N.; LEITE, Lígia S. Alfabetização tecnológica do professor. Petrópolis, RJ: Vozes, 2011.

NUNCIO, A. P. et al. Qr Code Como Estratégia Para Aprendizagem de Conteúdos de Ciências. In: CONGRESSO INTERNACIONAL DE EDUCAÇÃO, 7., 2017, Santa Maria. Anais... Santa Maria, 2017. 


\title{
Interdisciplinar (História e Sociologia) e Filosofia
}

\section{5 \\ A APLICABILIDADE DA AVALIAÇÃO POR CONCEITOS NO ENSINO MÉDIO}

\author{
Anderson Boppsin da Silva \\ absilva18@ucs.br \\ Subprojeto de História - EEEM Melvin Jones*
}

O presente trabalho ocupa-se em fazer uma análise da aplicação de avaliação por sistema de conceitos na Educação Básica da rede pública, especificamente na Escola Estadual Melvin Jones, de Caxias do Sul. A análise parte das observações feitas durante as intervenções do grupo de História do Pibid-UCS que atua com os $2^{\circ}{ }^{\circ}$ anos do Ensino Médio no turno da manhã, e busca interligar essas práticas às teorias educacionais sobre a avaliação que Celso dos Santos Vasconcellos traz na obra Avaliação: concepção dialéticalibertadora do processo de avaliação escolar (2005), comparando também com alguns outros relatos de profissionais da educação brasileira, para assim pensar as mudanças e permanências desse sistema de conceito, em relação às notas numéricas, bem como a influência dele em momentos dos processos de ensino e aprendizagem.

A rede pública de educação, do Estado do Rio Grande do Sul, passou a padronizar a avaliação através do sistema de avaliação emancipatória no Ensino Médio, utilizando um parecer descritivo com três conceitos nominais: Construção Satisfatória de Aprendizagem (CSA), Construção Parcial de Aprendizagem (CPA) e Construção Restrita de Aprendizagem (CRA). A ideia defendida na implantação do sistema é sair da rigidez das notas numéricas, passando a preocupar-se mais em entender as dificuldades apresentadas pelos estudantes, para assim buscar superá-las, e não apenas classificá-los. Na prática, os conceitos ajudam os professores a preocuparem-se mais com o aprendizado, porém, não serão nada diferentes da nota, se as ferramentas de avaliação se mantiverem as mesmas. Isso porque, a maneira como se registra

\footnotetext{
${ }^{*}$ Coordenadora do Subprojeto: Profa. Me. Eliane Machado Correa Cardoso. Supervisora: Profa. Fabrícia Clave.
} 
é apenas uma parte de todo o processo de educação, como nos apresenta Vasconcellos:

Há que se distinguir, inicialmente, "Avaliação" de "Nota". Avaliação é um processo abrangente da existência humana, que implica uma reflexão crítica sobre a prática, no sentido de captar seus avanços, suas resistências, suas dificuldades e possibilitar uma tomada de decisão sobre o que fazer para superar os obstáculos. A nota, seja na forma de número (ex.: 0-10), conceito (ex.: A, B, C, D) ou menção (ex.: Excelente, Bom, Satisfatório, Insatisfatório), é uma exigência do sistema educacional. Podemos imaginar um dia em que não haja mais nota na escola - ou qualquer tipo de reprovação - mas certamente haverá necessidade de continuar existindo avaliação, para acompanhar o desenvolvimento dos educandos e ajudá-los em suas eventuais dificuldades. (VASCONCELLOS, 2005, p. 54).

Quando as ferramentas de avaliação se restringem a provas, trabalhos com questionários e semelhantes, o vício do professor é simplesmente utilizar uma conversão simplória dos pontos (nota), em valores para os conceitos. Nas atividades propostas pelo grupo do Pibid na Escola Melvin Jones, durante o ano letivo de 2017, e citando também o trabalho do ano anterior, realizado pelo grupo na Escola Estadual Técnica Caxias do Sul, foram experimentadas diferentes abordagens, tanto utilizando-se ferramentas mais tradicionais, como prova, redações, como também buscou-se avaliar através de debates, seminários, discussões em pequenos e no grande grupo. Quando os trabalhos envolvem questões, sejam elas objetivas ou dissertativas, quase automaticamente o professor transforma $X$ número de acertos em cada um dos conceitos, o que não difere praticamente em nada a utilização de um sistema de notas numéricas. As ferramentas menos rígidas, como os debates, proporcionam uma utilização melhor do sistema emancipatório, justamente porque força a uma análise mais profunda do desempenho do estudante para a formação do conceito, e assim permite que a avaliação seja mais reflexiva. Ainda que isso não garanta êxito do processo, nos dá mais possibilidades de entender a situação de cada estudante. Esses registros têm uma função, segundo Jussara Hoffmann, que nem sempre é levada à prática.

Em que medida descrevo o que observei nas tarefas dos alunos de forma a entender o seu momento no processo? As anotações feitas sobre ele permitem-me perceber as diferenças entre seus entendimentos? 
Sugerem-me ações alternativas de prosseguimento em relação às dificuldades individuais? Os registros de avaliação devem responder essas questões que parecem esquecidas na escola e que de fato dão significado às perguntas principais: $O$ aluno aprendeu? /Ainda não aprendeu? /Por que não aprendeu? Quais os encaminhamentos feitos ou por fazer nesse sentido? (HOFFMANN, 2000, p. 84).

Por muitas vezes, o erro nem é percebido num primeiro momento. Citando outro momento da nossa participação na escola. Quando procuramos dar o retorno aos estudantes do desempenho deles no primeiro trimestre de atividades realizadas pelo Pibid, buscamos conversar com eles individualmente, explicando onde tiveram, ou não, êxito e por quais motivos, para aí sim informar o conceito final do trimestre. Também solicitamos que nos dessem sugestões de metodologias, nas quais cada um se sentisse mais produtivo. No momento essa postura pareceu a mais adequada, visando a uma real aprendizagem desses estudantes; entretanto, as atividades seguintes demonstraram que, para aqueles que haviam recebido conceitos baixos, essas avaliações, possivelmente, os tenha desmotivado, ao contrário da ideia inicial do grupo, de apontar onde estavam os problemas. Fazendo essa análise posterior, é possível perceber que não saímos da lógica do prêmiorecompensa (VASCONCELLOS, 2005), visto que utilizamos isso apenas para justificar o conceito que cada um havia recebido.

A substituição de notas numéricas por outras maneiras de avaliação, menos classificatórias, é uma ferramenta com grandes possibilidades de êxito nos processos de ensino e aprendizagem, porém, pode não surtir efeito algum, se o próprio professor não entender sua lógica reflexiva. Sabemos que a burocracia, o sistema escolar defasado, e a desvalorização da profissão dificultam que o profissional exerça seu trabalho da melhor maneira, porém, é dever do educador utilizar-se das ferramentas possíveis para possibilitar aprendizagem em seus estudantes. Entrar na zona de conforto, como a simplicidade de avaliar classificatoriamente, não trará avanços à educação.

Palavras-chave: Educação. Avaliação. Educação emancipatória. Avaliação por conceitos. 


\section{Referências}

HOFFMANN, Jussara. Avaliação mediadora: uma prática em construção da pré-escola à universidade. Porto Alegre: Mediação, 2000.

VANCONCELLOS, Celso dos Santos. Avaliação: concepção dialética-libertadora do processo de avaliação escolar. 15. ed. São Paulo: Libertad, 2005. 
ATIVIDADE SOBRE FILOSOFIA DA NATUREZA EM SALA DE AULA

\author{
Mateus da Silva Maciel ${ }^{*}$ \\ mateusmaciel914@gmail.com \\ Subprojeto Filosofia \\ Escola Estadual de Ensino Médio São Caetano
}

Resumo: O presente trabalho traz reflexões e discussões acerca das atividades realizadas em sala de aula pelo grupo Pibid-UCS, na E.E. São Caetano, em Caxias do Sul-RS, onde foram ministradas diversas oficinas com temas filosóficos. Destacando o problema: Por que é necessária uma nova ética? Quais as consequências já existentes da tecnologia? E quais as possíveis futuras consequências? A oficina "Hans Jonas: O Princípio Responsabilidade", teve como norteadora a reflexão sobre a proposta de responsabilidade que o autor coloca como um ensaio para uma nova ética. Tendo em vista as mudanças que ocorreram no mundo em suas mais diversas esferas, como o avanço tecnológico e as alterações na estrutura do pensamento projetado para a modernidade e contemporaneidade. Nesse contexto, Hans Jonas direciona o conceito de responsabilidade para o centro de sua ética, através da heurística do medo. Essa proposta pretende salvar as gerações futuras, preservando a natureza, através de um fazer coletivo. A fim de que os alunos pudessem perceber e compreender a importância do assunto trazido pelo autor, optou-se pelo uso de mídias, uma vez que as mesmas são, além de acessíveis, bastante eficientes ao instigar a participação e atenção dos alunos. Por fim, evidencia-se a importância de mais atividades reflexivas que permitam aos alunos debaterem sobre suas próprias experiências e o seu dia a dia.

Palavras-chave: Responsabilidade. Ética. Tecnologia. Futuro. Natureza.

\title{
1 Introdução
}

\subsection{Contextualização}

O presente trabalho traz reflexões e discussões acerca das atividades realizadas pelo grupo Pibid-UCS de Filosofia, em sala de aula. A equipe, composta por nove integrantes, dentre os quais, sete alunos e dois professores, desenvolveu atividades lúdico-pedagógicas no âmbito filosófico, procurando abordar, sobretudo, questões éticas. O local onde as oficinas são desenvolvidas localiza-se no Bairro São Caetano, em Caxias do Sul, e no qual a supervisora da equipe leciona Filosofia. Nesta perspectiva, uma vez que a professora conhece e convive com as turmas de Ensino Médio, as oficinas são pensadas a partir das

\footnotetext{
*Aluno de Graduação em Filosofia da Universidade de Caxias do Sul. Coordenador Prof. Dr. Luis Fernando Biasoli. E-mail: Ifbiasoli@ucs.br Supervisora Profa. Me. Tenisa Zanoto Boeira. E-mail: enisa.boeira@gmail.com
} 
demandas trazidas por ela e desenvolvidas e planejadas durante os encontros semanais.

Tendo como ponto de partida a iminente barbárie sofrida, diariamente, pela natureza e pelo avanço desenfreado da tecnologia, o pensamento e a filosofia de Hans Jonas parecem sobressair-se como tema e proposta para a aplicação de uma das atividades das oficinas. Para tanto, buscou-se explicitar e fundamentar alguns dos problemas trazidos pelo autor em sua obra $O$ princípio responsabilidade: ensaio de uma ética para a civilização tecnológica, na qual Hans Jonas traz uma nova maneira de se enxergar e viver no mundo.

\subsection{Objetivos}

Destacando o problema: Por que é necessária uma nova ética? Quais as consequências já existentes da tecnologia? E quais as possíveis futuras consequências? A oficina "Hans Jonas: O Princípio Responsabilidade" teve como norte a reflexão sobre a proposta de responsabilidade que o autor coloca como um ensaio para uma nova ética. A atividade não teve a pretensão de estabelecer conceitos de certo ou errado, mas fazer com que os alunos, nascidos em meio a essa realidade de avanço tecnológico, conseguissem enxergar, no seu mundo, os possíveis problemas trazidos pelo autor em sua obra. Desse modo, buscou-se proporcionar aos alunos não uma resposta, mas uma direção à solução de tais questionamentos.

\subsection{Metodologia}

Tendo em vista os diferentes contextos e as realidades do público-alvo, uma vez que os alunos possuem entre si distintas formas de compreensão e assimilação de conteúdos, a escolha da atividade se deu a partir da pretensão de que todos pudessem entender o tema e acessar o conteúdo de forma simples e didática. Para tanto, o grupo escolheu como ferramenta, mídias, mais especificamente o episódio da terceira temporada da série Black Mirror. O seriado, criado por Charlie Brooker, tem como gênero a ficção científica, e aborda temas obscuros e satíricos, que examinam a sociedade moderna, especialmente, a partir das consequências das novas tecnologias. 
Nesse âmbito, com tempo estimado para duas horas, a oficina foi ministrada por dois integrantes do programa institucional de bolsas de iniciação à docência (Pibid), e teve como proposta o questionamento: "Com a tecnologia avançando cada vez mais, o ideal de felicidade está cada vez mais próximo? Ou este "avanço tecnológico" poderá acabar com a integridade humana?"

Dando início à oficina, no intuito de fazer com que os alunos compreendessem a origem de seus pensamentos, objetivos e conclusões, foi realizada, nos primeiros dez minutos, uma breve apresentação biográfica de Hans Jonas, seguida por uma contextualização sucinta da época em que ele viveu e escreveu a obra.

Posteriormente, nos vinte minutos seguintes, iniciou-se uma fase conceitual do projeto, em que foi apresentada aos alunos a proposta do autor: seu pensamento e sua vontade em querer produzir uma nova ética. Algo que abarcasse não só a busca pela felicidade, o fazer bem, o justo, o livre, mas uma ética que, também, se adaptasse ao avanço tecnológico que o mundo está vivenciando. Hans Jonas introduz o conceito de responsabilidade já presente na ética tradicional; porém, o conceito de responsabilidade toma um lugar de destaque, sendo a base de todo o princípio no qual os alvos são a natureza e o futuro.

$\mathrm{Na}$ hora seguinte, os alunos tiveram a oportunidade de assistir ao episódio "Engenharia Reversa", que provoca e desperta reflexões éticas acerca dos efeitos tecnológicos, mais especificamente no episódio sobre a eugenia.

Destaca-se que a utilização da mídia foi vista como uma ferramenta eficaz, pois foi possível prender a atenção dos alunos com demonstrações claras de um dos muitos possíveis efeitos colaterais, que o avanço tecnológico desenfreado pelo qual estamos passando, nas últimas décadas, é capaz de causar à humanidade. Também possibilitou ser feita a conexão direta com a proposta trazida pelo autor em sua obra.

Por fim, nos vinte minutos finais houve um debate, em que os alunos falaram sobre os temas tratados na oficina, expressaram diferentes pontos de vista, argumentaram suas opiniões e conseguiram enxergar a proximidade da proposta filosófica do autor com o tema tratado em mídia e, consequentemente, com o mundo de hoje. 


\section{Marco teórico}

"O legado de Hans Jonas é de fundamental importância para a filosofia contemporânea, especialmente no âmbito da ética" (SANTOS, 2011, p. 130), pois, ao longo dos últimos séculos, são evidentes as mudanças que ocorreram no mundo em suas mais diversas esferas. Das "invasões" tecnológicas ocorridas na época moderna que marcaram, fortemente, os séculos XVIII, XIX e XX, e a estrutura de pensamento projetada pela modernidade à contemporaneidade, desviada no meio de seu caminho, principalmente por questões levantadas por Friedrich Nietzsche, Hans Jonas encontra sua porta de entrada.

O autor acredita que o surgimento de uma ética da responsabilidade é necessário para que o mundo tenha alguma chance de continuar existindo. Não só pelas "feridas abertas" que Nietzsche deixou na ética tradicional, assim como por diversos outros pensadores, mas pela própria ética tradicional não incluir o avanço tecnológico que o mundo vem sofrendo em sua reflexão. "A ação humana teve sua esfera de alcance progressivamente ampliada por meio da melhoria contínua dos 'meios'". (SANTOS, 2011, p. 132). Devido à tecnologia, o homem teve o alcance de suas ações ampliadas numa escala gigantesca e, consequentemente, seus efeitos.

Hans Jonas traz uma proposta alicerçada na crítica às éticas tradicionais e na crítica à técnica como ideia moderna de progresso e ao ideal baconiano de dominação da natureza. Essa dominação, operada progressiva e exclusivamente por meio da técnica, constitui-se, para o autor, na ameaça iminente de autoaniquilação do ser humano. (SANTOS, 2011).

Portanto, Hans Jonas oferece uma ética que supra as lacunas deixadas pela ética tradicional e que se preocupe pura e simplesmente com a preservação da vida. Para isso, cria-se um novo imperativo: "Aja de tal forma que os efeitos de tua ação sejam compatíveis com a permanência de uma vida autêntica na terra". (JonAs, 2006). Essa nova ética, trazida por Jonas, pretende salvar as gerações futuras preservando a natureza, através de um fazer coletivo. Ele destaca o fato de que a ética sempre esteve relacionada ao agir humano, porém, agora, há uma tecnologia que antes não havia, e, justamente por isso, deve-se ter maior cuidado na hora de agir. Segundo Jonas, 
nenhuma ética anterior vira-se obrigada a considerar a condição global da vida humana e o futuro distante, inclusive a existência da espécie. O fato de que hoje eles estejam em jogo exige, numa palavra, uma nova concepção de direitos e deveres, para a qual nenhuma ética e metafísica antiga pode sequer oferecer princípios, quanto mais uma doutrina acabada. (2006, p. 41).

Tendo isso como fato incontestável, Hans Jonas direciona o conceito de responsabilidade para o centro de sua proposta, através da heurística do medo. O autor constata que sabemos valorizar, dialeticamente, a vida como algo sagrado, na medida em que conhecemos o que é a sua aniquilação. A perda de algo ou a mera representação de sua perda provoca, instantaneamente, uma valorização do mesmo objeto em questão. (SANTOS, 2011). Isto é, a previsão não espontânea, mas intencional - de uma deformação do humano e da natureza possa vir a contribuir para que o ser humano passe a assumir a responsabilidade e preservar a humanidade e a natureza.

\section{Considerações finais}

Com a realização da atividade proposta, foi possível perceber, entre vários componentes, a importância do estímulo à reflexão. Através da interação em sala de aula, os alunos puderam observar a si mesmos e ao outro, de forma a beneficiar todos os envolvidos. É interessante salientar que do debate entre alunos e ministrantes, ocorrido na parte final da oficina, suscitaram-se muito mais questionamentos que respostas. Todos expuseram seus argumentos e pontos de vista embasados em suas próprias experiências e opiniões, demonstrando entender não só a proposta trazida pelo autor e o motivo que o levou a propor uma nova ética, como também algumas das possíveis consequências que podem vir a ocorrer, caso as atitudes humanas, em posse dessa nova tecnologia, não mudarem.

Diante do entendimento dos alunos sobre a importância do tema proposto e da participação ativa nos questionamentos e nas reflexões, foi possível vislumbrar os objetivos atingidos. Embora não se tenha chegado a conclusões unânimes para os problemas levantados, foi possível perceber a dedicação e o 
entusiasmo por parte dos alunos, em encontrar tais respostas, de modo que a filosofia, também, cumpriu o seu papel.

Nessa perspectiva, fica evidente o impacto que as atividades do Pibid são capazes de causar em jovens do Ensino Médio, assim como a importância de se continuar realizando trabalhos como este, não em uma, mas em diversas escolas do município. O programa de bolsas de iniciação à docência é uma iniciativa que, além de propiciar melhores condições de aprendizado prático para futuros professores, instiga a busca pelo conhecimento de jovens estudantes. Dessa forma, fica latente, também, o interesse do grupo em, futuramente, vir a planejar e executar mais atividades nesse âmbito de descobertas filosóficas, a fim de compreender melhor o dia a dia e o contexto da comunidade envolvida.

\section{Referências}

JONAS, Hans. 0 princípio responsabilidade: ensaio de uma ética para a civilização tecnológica. Rio de Janeiro: Ed. da PUC do Rio, 2006.

SANTOS, Robinson dos. O problema da técnica e a crítica à tradição na ética de Hans Jonas. Revista Bioethikos, São Paulo, v. 5, n. 2, p. 130-140, abr./jun. 2011. 
FÍSICA E A HISTÓRIA DO CALOR: RELATO DE UM PROJETO INTERDISCIPLINAR

\author{
Gabriela Gonzalez Matias \\ gabigmtessaro@gmail.com \\ Subprojeto Interdisciplinar (História e Sociologia) \\ Escola Estadual de Ensino Médio Professor Apolinário Alves dos Santos
}

Resumo: Percebendo a falta de valor atribuída às aulas, especialmente as que abrangem as ciências exatas, procuramos envolver o aluno com seu próprio aprendizado, fazendo-o tirar melhor proveito dessas aulas, embasando o conteúdo de Física com História, para perceber o conceito de calor e seus usos nas profissões. O projeto teve como objetivo levar o estudante a entender que tudo o que aprende na escola pode utilizar em sua vida. Essa questão é recorrente na sala de aula, isto é, "onde utilizarei este conhecimento?" Nossa vontade foi desmitificar conceitos vindos do senso comum e mostrar, de forma interdisciplinar, que a ciência de qualquer área é importante, pessoal, social e profissionalmente.

Palavras-chave: História. Física. Calor. Interdisciplinaridade.

\title{
Introdução
}

Existe uma dificuldade em relação às aulas de ciências exatas na escola. No esforço de calcular ações que parecem abstratas, os alunos não encontram valor no aprendizado e desmotivam-se com as atividades propostas pelo professor.

Em relação às ciências humanas, parece mais fácil, pois, ao emitir uma opinião um pouco mais estruturada, já começa a construção do conhecimento. 0 jovem está preocupado com seu futuro, e não consegue perceber que a escola como um todo é importante na sua formação. Visando a essa preocupação, preparamos um trabalho focado nos conceitos da Física, embasado nos conceitos históricos do calor e na aplicação desse conhecimento, nas profissões mais procuradas atualmente. A atividade contou com dois momentos de aula expositivo-dialogada, um momento para a formação de grupos e proposta de atividade e, por fim, apresentação e avaliação da atividade.

\footnotetext{
* Coordenadora do subprojeto: Profa. Dra Eliana Rela. Supervisora Profa. Suélen Cristina Boeck. Colaboradora: Profa. Eloísa Padilha. Bolsista Pibid Bruno Rodrigues da Silva Damin.
} 


\section{Referencial teórico}

O projeto nasceu a partir da preocupação da Profa. Eloísa Padilha com a falta de interesse dos alunos em aprender o conteúdo de Física. A maior dúvida dos estudantes é onde usarão o que aprenderam na matéria; sem essa questão esclarecida, perdem a motivação nos estudos, mesmo para aqueles que farão o Vestibular.

Partindo desse ponto, pensou-se em trabalhar a interdisciplinaridade com a Física e a História, para tornar as aulas mais interessantes para os alunos. $\mathrm{O}$ módulo do conteúdo abordado foi o Calor/Temperatura,

[...] pois é relevante a dificuldade de compreensão que o conceito de calor carrega para o processo de ensino e de aprendizagem e que, por essa consideração, deve-se acreditar que o ensino desse conceito se torna um desafio para qualquer tentativa nesse sentido. (SILVA; LABURÚ; NARDI, 2008, p. 385).

Visando ao futuro, o projeto foca nas profissões mais procuradas atualmente, nas quais o calor contribui de forma direta para sua execução. Com isso, oportuniza o estudante a compreender que os conteúdos curriculares estão presentes em sua vida. Nossa vontade quer desmitificar conceitos vindos do senso comum e mostrar que a ciência, de qualquer área, é importante, pessoal, social e profissionalmente.

A pesquisa foi direcionada para a descoberta do fogo, cientistas que descobriram como trabalhar com ele e curiosidades. Os alunos foram organizados em grupos para a realização do trabalho e orientações para a avaliação. As profissões escolhidas foram: Arquitetura, Engenharia Ambiental, Engenharia de Alimentos, Engenharia de Materiais, Engenharia Elétrica, Engenharia Mecânica, Engenharia Química, Estética, Farmácia, Fisioterapia. A apresentação do trabalho foi escrita e compartilhada com a turma e com a professora Eloísa.

\section{Descrição da atividade desenvolvida}

O projeto foi a primeira experiência, juntamente com meu colega Bruno. Os encontros com a professora Eloísa, para a discussão da atividade, começaram 
no dia 23 de abril de 2015; o último foi dia 17 de setembro de 2015 e ocorriam a cada quinze dias. 0 trabalho foi feito para as turmas do 20 ano do Ensino Médio e foi dividido: eu fiquei com as curiosidades sobre o fogo; o Bruno, com os cientistas e seus feitos em relação à temperatura.

Nossa pesquisa começou dia 30 de abril de 2015. Até o dia da apresentação em sala de aula, o Bruno e eu estudamos Física, os cientistas, os acontecimentos históricos, as curiosidades; descobrimos que a ciência não tinha somente cálculos. Confeccionamos uma linha do tempo com os cientistas e uma apresentação de slides para as curiosidades.

A apresentação em sala de aula começou comigo, e os slides, no dia 25 de setembro de 2015, para todas as turmas, cada uma com seu período de cinquenta minutos; e assim ocorreu com o Bruno e a linha do tempo, no dia 9 de outubro de 2015. Elaboramos a orientação para o trabalho, mas decidimos não participar da avaliação, deixando a Profa. Eloísa encarregada da apreciação.

\section{Metodologia}

Para trabalhar com interdisciplinaridade, a escolha da estratégia é importante, por isso fizemos aula expositiva dialogada; as ideias relacionadas à Física e à História foram discutidas com a turma "[...] é preciso dominar o processo, conhecendo suas etapas e preparando-as. [...] Trabalhar além do conteúdo é um desafio, que corresponde ao processo de autonomia a ser conquistado com e pelo aluno". (ANASTASIOU, 2004, p. 76).

Foram dois períodos de 50 minutos de aula expositivo-dialogada, um período para a divisão dos alunos em grupos e as orientações para o trabalho e mais dois períodos para a apresentação. A Profa. Eloísa ficou com a tarefa de avaliar a escrita, o domínio do assunto, a postura e a organização. Escolhemos 10 profissões, os estudantes pesquisaram a aplicação do calor/temperatura em cada uma delas. $O$ resultado foi apresentado em formato de trabalho escrito e compartilhado com os colegas.

\section{Considerações finais}

Fazer um projeto interdisciplinar, trabalhar com a Profa. Eloísa, que possui um conhecimento na docência em uma área diferente da que pretendo atuar, foi 
produtivo em vários aspectos e trouxe crescimento não somente profissional como pessoal. A visão do trabalho em sala de aula ampliou-se, permitindo perceber uma parte boa da Física que eu não havia notado antes, isto é, ela e a História "conversam" entre si e podem ser parecidas.

Acredito que todo trabalho interdisciplinar é válido pela riqueza de conhecimento compartilhado que traz consigo. Na troca de conhecimento que ocorre entre professores, quem sai ganhando é o aluno, pois tem uma aula interessante, aprende um modo diferente de pensar e estudar, o que contribui para uma aprendizagem mais eficiente.

\section{Referências}

ANASTASIOU, Léa das Graças Camargos; ALVES, Leonir Pessate. Processos de ensinagem na universidade: pressupostos para as estratégias de trabalho em aula. 3. ed. Joinvile, SC: Univille, 2004.

CHAGAS, Aécio Pereira. A história e a química do fogo. Campinas, SP: Átomo, 2006. (Coleção ciência \& entretenimento).

CORREIA, Nestor. A história da Física na educação brasileira. Disponível em: <http://www.histedbr.fe.unicamp.br/revista/revis/revis14/art7_14.pdf>. Acesso em: 17 jan. 2017.

FIGUEIREDO, Aníbal; PIETROCOLA, Maurício. Calor e temperatura: ilustrações de Estúdio Graal I. São Paulo: FTD, 1997. (Física um outro lado).

SILVA, Osmar Henrique Moura da; LABURU, Carlos Eduardo; NARDI, Roberto. Reflexões para subsidiar discussões sobre o conceito de calor na sala de aula. Cad. Bras. Ens. Fís., v. 25, n. 3, p. 383-396, dez. 2008. 
INCLUSÃO E EXERCíCIO DE CIDADANIA NO PIBID-UCS HISTÓRIA

\author{
Alessandra Cardoso \\ acardoso3@ucs.br \\ Subprojeto História \\ Escola Municipal de Ensino Fundamental Tancredo Neves e \\ Escola Estadual de Ensino Médio Melvin Jones ${ }^{*}$
}

\title{
Introdução
}

Este artigo aborda o tema da inclusão escolar, analisando as vivências com o subprojeto do Pibid-UCS História na Escola Municipal de Ensino Fundamental Tancredo Neves. Apesar de ser um assunto recorrente na atualidade, a inclusão ainda precisa ser muito discutida, analisada e posta em prática e, para isso, a reflexão a respeito do processo inclusivo é tão importante.

\section{Objetivo}

O objetivo do artigo é promover a disseminação do conhecimento sobre a maneira como as escolas têm realizado a inclusão e como elas influenciam a vida dos estudantes e da comunidade. A partir dos relatos e das perspectivas apontadas no texto, promover o levantamento de soluções para as práticas inclusivas.

Período de realização das atividades: Fevereiro a agosto de 2017.

Quando o ambiente escolar entra em voga, a palavra formar seguida de cidadãos aparece como se não houvesse modo de dissertar sobre educação, sem mencionar a cidadania. E, de fato, este é um dos objetivos que as instituições públicas e privadas estabelecem como meta-base. Ademais, têm a intenção de desenvolver em seus alunos o senso crítico e garantir as condições necessárias

\footnotetext{
* Coordenadora do subprojeto: Profa. Me. Eliane Machado Correa Cardoso. Supervisor Prof. Me. Paulo Afonso Lovera Marmentini da escola Municipal de Ensino Fundamental Presidente Tancredo Neves. Supervisora Profa. da Escola Estadual de Ensino Médio Melvin Jones: Fabrícia Clave.
} 
para a aprendizagem. Émile Durkheim, sociólogo francês, afirmava que a função da educação era a transmissão de valores morais e visava à integração do indivíduo no contexto da sociedade. Contudo, a escola é capaz de humanizar, fazer pensar e integrar o indivíduo? E mais, seria ela o agente com maior chances de transformar a sociedade?

Segundo Durkheim, a escola é o meio onde a sociedade é reproduzida e perpetuada. A configuração do ensino durante os séculos pode nos auxiliar no entendimento da organização social, da mesma forma que a organização social possibilita entender a configuração escolar. A escola é uma instituição fundamental na sociedade e tornou-se universal diante do interesse em difundir e consolidar uma cultura, que promovesse a coesão entre pessoas de grupos sociais diversos com interesses diversificados e estabelecesse a compreensão e aceitação de princípios. (FERREIRA, 2005). Bem como, adveio da necessidade de formar pessoas capacitadas para o trabalho. Desde sua tentativa de incluir no público classes menos abastadas que a elite, o sistema educacional excluía os educandos, a partir do momento em que a escola formava, baseada na condição de vida, trabalhadores braçais ou intelectuais. Perceba que, ao incluir a escola já excluía. Limitava grande parte dos alunos a aprenderem apenas aquilo que contribuiria com o bom funcionamento da sociedade.

Se a educação perpetua a sociedade, então a escola é o reflexo das práticas transmitidas. Logo o que presenciamos na educação brasileira é uma evidente segregação dos educandos pela condição econômica, geográfica e étnica, além das individualidades que cada um deles apresenta. A inclusão está baseada no acesso igualitário de todos os estudantes ao ensino de qualidade, contudo: "Percebe-se, hoje, que a simples colocação dessas crianças na rede regular de ensino não lhes garante o direito a uma educação de qualidade. Nesse sentido, o que se tem percebido é que, em muitas situações, propomos a educação inclusiva e temos uma prática de integração escolar". (SouZA, 2008, p. 13).

A integração escolar tem como objetivo organizar a comunidade em prol da aprendizagem, boa convivência e felicidade dos discentes. Por isso, é essencial a consciência da resposta para a seguinte pergunta: Quem precisa ser incluído? A inclusão não deve ficar limitada aos alunos que necessitam de atendimento especial, precisa chegar a todos. Isso significa lidar com diversas realidades, entender e respeitar a individualidade. A garantia dessa singularidade 
facilita o desenvolvimento de identidade e reconhecimento que a criança e o adolescente têm de si e propicia um ambiente confortável para o ensino. A escola tem se tornado o espaço de busca do cidadão pronto para o mercado de trabalho, o almejado "ser alguém na vida", que está estritamente relacionado com a ambição salarial e status social. Mas sabemos que ela é muito mais e pode possibilitar milhares de experiências culturais, artísticas e humanas.

Na Escola Municipal de Ensino Fundamental Presidente Tancredo Neves, onde o subprojeto de História do Pibid da Universidade de Caxias do Sul atua, alguns alunos apresentam capacidades motoras e cognitivas limitadas. A escola conta com monitores que auxiliam na realização de atividades e fazem o acompanhamento das crianças. Porém, assim como grande parte das tentativas de inclusão, a monitoria fica limitada ao supervisionamento enquanto o professor concentra sua atenção na execução da aula. A consequência é exclusão social e más condições de aprendizagem. Esse tipo de situação afeta tanto o aluno "especial" quanto os demais integrantes da sala.

se não tivermos a coragem de manter uma discussão séria, corremos o risco de continuar vendo, na prática, apenas a inserção física dos portadores de necessidades educacionais especiais na rede regular de ensino, com interações baseadas na solidariedade mecânica, quando os sujeitos continuam na marginalidade, excluídos do processo de aprendizagem. (SOUZA, 2008, p. 17).

A inclusão transfigura-se num fator agravante da exclusão. Os alunos com necessidades motoras ou cognitivas são prejudicados por não se adaptarem ao programa estabelecido pelas instituições, ou seja, não aprendem com qualidade e, com o passar dos anos e das matérias estudadas, a frustração aumenta, pois o nível de compreensão baixa. Ainda há o problema de acessibilidade nas dependências escolares, configura mais um limite que barra o processo de pertencimento e interação social. O mesmo ocorre com os demais alunos. A principal barreira, neste caso, é a cultural. O professor entra na sala, explica a matéria, escreve no quadro e passa alguma atividade, ao soar do sinal ele sai e o ciclo se repete. Esse distanciamento é ocasionado por diversos fatores, dentre eles o tempo e a quantidade de conteúdos a serem transmitidos. Até que ponto o relacionamento entre aluno e professor influencia no processo de 
aprendizagem? O que nós, como educadores, podemos fazer para diminuir os impactos negativos que a divisão social causa nos estudantes?

\section{Considerações finais}

Para garantir cidadania, é fundamental fazer valer os direitos dos cidadãos. A integração dos estudantes se dá num ambiente onde sua individualidade seja reconhecida e respeitada, suas necessidades físicas e/ou cognitivas não os impeçam de receber um ensino de qualidade. Se a sociedade é perpetuada na escola, que essa escola seja de todos e para todos.

Palavras-chave: Acessibilidade. Educação. Inclusão. Pibid. História.

\section{Referências}

DAYRELL, Juarez. Múltiplos olhares sobre a educação e cultura. Belo Horizonte: UFMG, 1996.

DOTTI, Corina Michelon. Diversidade e inclusão: reconfiguração da prática pedagógica. 11. ed. Caxias do Sul, RS: Educs, 2008.

FERREIRA, Antônio Gomes Alves. A difusão da escola na afirmação da sociedade burguesa. In: ALMEIDA, Malu. Políticas educacionais e práticas pedagógicas: para além de mercadorização do conhecimento. Campinas, SP: Alínea, 2005.

GOMES, Candido. A educação em perspectiva sociológica. São Paulo: EPU, 1985.

PACHECO, José. Caminhos para a inclusão: um guia para o aprimoramento escolar. Porto Alegre: Artmed, 2007. 


\title{
29 \\ O PENSAMENTO SOCIOLÓGICO COMO FORMA DE EMANCIPAÇÃO E TRANSFORMAÇÃO
}

\author{
Steffany Cardoso \\ steffanycardoso2@gmail.com \\ Subprojeto Interdisciplinar (História e Sociologia) \\ EMEF Governador Leonel Brizola
}

Resumo: Uma vez tida a consciência da influência social e histórica que causamos à comunidade na qual estamos inseridos, somada ao dever que Paulo Freire, em Educação e mudança, dá ao educador, devemos ser sujeitos de mudança, amor e libertação. Ao trabalhar consecutivamente com duas turmas, através de aulas, saídas a campo, e oficinas para diversas outras turmas da escola, é possível realizar a aproximação necessária para conhecer a realidade da comunidade, instigar o autorreconhecimento como sujeito histórico nos alunos e provocar uma nova perspectiva de vida e mundo.

Palavras-chave: Educação. Violência. Social. Autonomia. Comunidade.

\section{Relato de experiência}

Pelas palavras de Paulo Freire, educar é um ato de amor ao mesmo tempo que é um ato político, e o educador, por sua vez, se dá como sujeito quando o educando se vê como agente da própria libertação e emancipação. Educar possibilita que o educando rompa suas amarras, buscando emancipação como cidadão politizado. Nesse sentido, lecionar e, sobretudo, lecionar os aspectos sociais da vida cotidiana, como parte de um conjunto muito maior da estrutura social mundial, é não só um ato de amor, mas um ato revolucionário. A Sociologia, como disciplina elementar da base curricular, não se vê ausente mesmo para o Ensino Fundamental; está realocada neste caso com a Geografia e a História, e, no caso particular dos 8o anos, com a geopolítica e a geografia humana. Enquanto estudante desta disciplina, me vejo inclinada a dar relevância aos aspectos com os quais esta escola influencia a vida de seus educandos, e em que estes núcleos familiares também influenciam as estruturas hierárquicas e docentes desta escola. Iniciei no Pibid na última semana de aula da EMEF Governador Leonel Brizola, de 2016.

\footnotetext{
* Coordenadora do subprojeto Profa. Dra. Eliana Rela.
} 
A escola atende em turno integral jovens que foram realocados de bairros com vulnerabilidade social para um condomínio disposto por política pública. De forma a privá-las de todo senso de comunidade e irmandade, coloca-os em um bairro distante, que pelos olhos dos próprios alunos - sofre discriminação pelo restante da população do município. A estrutura da escola conta com dois andares do Bloco J da Universidade de Caxias do Sul, alugados pela Prefeitura e adaptados para atender às necessidades de uma escola municipal, até que seja construído o prédio da escola no bairro. No projeto pedagógico da escola estão colocadas as particularidades das famílias atendidas e as necessidades obtidas ao longo do tempo de atuação. A equipe de coordenadoras e a direção mantêm um serviço também de assistencialismo voluntário ao qual tivemos contato. Tal gesto escancara outra característica determinante: o diálogo frequente e o contato individual e pessoal permitem com que os educandos tenham nos professores um suporte psicológico e um refúgio para questões da vida familiar. Tendo esta tarefa em vista, vê-se no plano pedagógico tais atitudes também através das frequentes saídas a campo e das oficinas, que exemplificam uma forma de educar que pode ser divertida e que os aproxima.

O Campos da Serra já é visto pelo alto índice de miséria, no que diz respeito às condições básicas de sobrevivência e ao sentimento de pertencimento; condições que se refletem na vida dos moradores, através de atritos constantes entre si e entre os agentes da segurança pública. Tais fatores trazem grandes dificuldades para a vida dos moradores, que podem contar com poucos serviços da rede de assistência. Nos relatos obtidos em sala de aula, constantemente os educandos expunham rivalidades entre moradores e que chegavam a ponto de o morador de um prédio não ter a permissão de frequentar outro. Tal violência também era exposta em relação ao serviço de policiamento agressivo, ao qual eram submetidos. Em consequência, a evasão escolar é absurdamente grande, pois objetiva obter renda para auxiliar nas necessidades de casa, e que, para as estudantes mulheres se dá por uma gravidez não planejada na adolescência, ou falta de estímulo e de perspectiva de uma vida diferente daquela que Ihes foi apresentada no seu cotidiano.

Tinham liberdade de diálogo conosco -, pois nos colocávamos não como autoridades irrepreensíveis sob a imagem de um professor clássico, mas como educadores que utilizam a mesma linguagem e buscam, na cumplicidade, o 
crescimento em conjunto. Isso nos colocou diante de situações inesperadas, que permitiam que os educandos conduzissem as aulas por meio de perguntas sobre a matéria, de forma que se sentissem à vontade para questionar a própria realidade e a própria vida, bem como as estruturas sociais e econômicas, no âmbito mundial. A geopolítica me proporcionou a experiência de relacionar temas e abordagens didáticas e a capacidade de identificar, ao longo do ano, o método do qual os educandos se mostravam mais dispostos a participar e gerar o próprio conhecimento. Ao mesmo tempo, é claramente perceptível o crescimento, não só individual, mas coletivo, que tiveram ao longo do ano letivo.

Sob a incerteza de continuação do Pibid, estou entristecida ao ter de me despedir dos estudantes - recuso-me a utilizar o termo "alunos", por supor que nossos estudantes ainda não possuem a "luz" do conhecimento, e por colocar o educador como um detentor da verdade e da sabedoria absoluta - e da escola. $E$ deixo registrada a necessidade não só de continuação do programa, mas de expansão. O Pibid deve ter fácil acesso a todos os acadêmicos, tendo em vista a riqueza das aprendizagens e das experiências que prevê à escola e aos "pibidianos". Tenho como crescimento pessoal as experiências de vida de cada estudante com os quais tive contato e, ainda mais para o meio acadêmico e profissional o primeiro acesso à vida docente e à comunidade escolar.

\section{Referência}

FREIRE, Paulo. Educação e mudança. 5. ed. Rio de Janeiro: Paz e Terra, 2004. 


\author{
Caroline Franchesca Silva de Lima* \\ cfslima@ucs.br \\ Everton Luiz Ferri** \\ iverton.ferry@gmail.com \\ Subprojeto: Filosofia \\ Escola Estadual de Ensino Médio São Caetano
}

\begin{abstract}
Resumo: Tendo como objetivo principal trazer como questões norteadoras: a importância do Pibid para o contexto educacional do Brasil e seu papel como programa de formação, valorização e incentivo à carreira docente, o texto em questão busca fomentar a discussão a respeito da importância que o programa teve, durante o processo de formação do bolsista. Abordando os objetivos do programa, o texto busca enfatizar a importância do Programa Institucional de Bolsas de Iniciação a Docência (Pibid), dentro do ensino básico, desde sua implementação pela Capes, no ano de 2007. Sob a ótica pessoal de ambos bolsistas do Pibid de Filosofia da Universidade de Caxias do Sul (UCS), o texto tem a intenção de trazer ao leitor uma breve síntese a respeito dos objetivos propostos pelo programa e das perspectivas e compreensões particulares que os autores possuem, a partir de suas experiências com o projeto em Filosofia: "A formação filosófica e a constituição ética do sujeito".
\end{abstract}

Palavras-chave: Formação. Processo. Ensino. Pibid.

\title{
Introdução
}

O Programa Institucional de Bolsas de Iniciação à Docência (Pibid) surgiu como uma iniciativa do Ministério da Educação; tem, como um de seus objetivos, o incentivo e a valorização da carreira docente, oportunizando, ao mesmo tempo, ao graduando de licenciatura maior experiência com a educação na rede pública. Implementado pela Capes - instituição vinculada ao MEC, no ano de 2007, o Pibid surge como uma nova política pública de educação, que tem como missão principal o aprimoramento da qualidade da formação docente, assim como visa também a melhorias que contribuam para haver maior qualidade de ensino na educação básica. O art. 30 do Decreto 7.219, de 24 de junho de 2010, dispõe sobre o PIBID e dá outras providências. São os objetivos do programa:

\footnotetext{
* Acadêmica do curso de Licenciatura em Filosofia, na Universidade de Caxias do Sul; bolsista de março de 2017 a fevereiro de 2018, do Pibid-UCS.

** Acadêmico do curso de Licenciatura em Filosofia, na Universidade de Caxias do Sul; bolsista de março de 2016 a fevereiro 2018, do Pibid-UCS.

Coordenador Prof. Dr. Luis Fernando Biasoli. Supervisora: Profa. Me. Tenisa Zanoto Boeira.
} 
I - incentivar a formação de docentes em nível superior para a educação básica;

II - contribuir para a valorização do magistério;

III - elevar a qualidade da formação inicial de professores nos cursos de licenciatura, promovendo a integração entre educação superior e educação básica;

IV - inserir os licenciandos no cotidiano de escolas da rede pública de educação, proporcionando-lhes oportunidades de criação e participação em experiências metodológicas, tecnológicas e práticas docentes de caráter inovador e interdisciplinar, que busquem a superação de problemas identificados no processo de ensino-aprendizagem;

V - incentivar escolas públicas de educação básica, mobilizando seus professores como formadores dos futuros docentes e tornando-as protagonistas nos processos de formação inicial para o magistério;

VI - contribuir para a articulação entre teoria e prática necessárias à formação dos docentes, elevando a qualidade das ações acadêmicas nos cursos de licenciatura.

Tais objetivos compreendem a necessidade de mudanças a respeito dos paradigmas de ensino, que ainda servem de alicerce para a educação brasileira. Trata-se de maior preocupação com a formação prática do futuro educador e não apenas sua teorização.

\section{Um incentivo à prática}

No texto “O PIBID como 'terceiro espaço' de formação inicial de professores", da Doutora em Educação Maria Helena dos Santos Felícidio (2014), a atuação e formação dos professores atualmente são descritos como um processo complexo. De acordo com a autora, "Tratando-se da formação inicial de professores, torna-se necessário combinar a formação acadêmica e a formação pedagógica, a fim de capacitá-los para o exercício de uma atividade que não se restringe, exclusivamente, a 'ministrar aulas'."

Tal posicionamento evidencia o trato com o qual a educação, no Ensino Superior tem se colocado a respeito da formação de professores no Brasil. $\mathrm{O}$ ato 
de educar um educador, por vezes, passa a ser um processo prático, quando mediante apenas a teoria vista na graduação.

Em particular, ao destacarmos os aspectos positivos do programa para a nossa formação pedagógica, podemos elencar dois pontos fundamentais:

- promover aos bolsistas a valorização do magistério;

- oportunizar aos bolsistas um contato mais próximo com a rotina e com as responsabilidades do professor.

Entretanto, tais benefícios a serem destacados não devem ofuscar outro fator de extrema importância ao qual o programa implica: o incentivo, ainda na escola, ao magistério. Sabemos que, após o ingresso no programa, no decorrer dos planejamentos e das atividades realizadas, a relação que o bolsista possui com o projeto tem extrema responsabilidade. Essa responsabilidade surgirá a partir da compreensão de seu papel como educador e a influência que, por vezes, implica diretamente, sob a forma como seus alunos veem o mundo.

Ainda, de acordo com Felícidio (2014), esse sentimento de comprometimento, que surge do contato com o magistério, por intermédio do programa, faz com que se acentue o "desenvolvimento da compreensão crítica, que aponta a valorização e o resgate do professor como agente de transformação e construção das alternativas pedagógicas para o sucesso escolar dos educandos".

O papel do Pibid nas escolas tem como reação o despertar da curiosidade daqueles alunos que não compreendem a importância de determinadas disciplinas, como, por exemplo, a Filosofia. As provocações que surgem a partir do trabalho com a disciplina não afetam todos os alunos, mas existe sempre um número considerável de interessados pela licenciatura, a partir do contato com os projetos subsidiados pelo programa.

\section{Conclusão}

O Programa Institucional de Bolsa de Iniciação à Docência (Pibid) possui muitos aspectos positivos. Atrativos que podem ser possibilitados não só aos seus bolsistas, como também à escola, aos alunos e à comunidade escolar em geral, em que o projeto está inserido. Para os bolsistas, o Pibid é mais que uma oportunidade de conhecer as atribuições dadas ao magistério. É um processo de 
autorreconhecimento contínuo, a respeito de si mesmo e do seu papel no mundo, como agente de transformação, como um educador.

Já para alguns alunos o projeto não passa de algumas horas de "entretenimento" perdidas dentro da escola; entretanto, para outros, o Pibid representa muito mais do que isso, é uma diretriz para o futuro.

\section{Referências}

BRASIL. Decreto 7.219, de 24 de junho de 2010. Disponível em: <http://www.planalto.gov.br/ccivil_03/_ato2007-2010/2010/decreto/d7219.htm>. Acesso em: 20 jan. 2018.

CAPES. Pibid - Apresentação. Disponível em: <http://portal.mec.gov.br/pibid>. Acesso em: 20 jan. 2018.

FELÍCIDIO, H. M. S. O PIBID como "terceiro espaço" de formação inicial de professores. Rev. Diálogo Educ., Curitiba, v. 14, n. 42, p. 415-434, maio/ago. 2014. Disponível em: <http://www.redalyc.org/html/1891/189131701006/>. Acesso em: 25 jan. 2018. 
31

POVOS INDÍGENAS AMERICANOS: REFLEXÕES SOBRE A PRÁTICA PEDAGÓGICA

Paulo Afonso Lovera Marmentini

pmarmentini@gmail.com

Rafael Stamm Marcolin

rafaelmmarcolin@gmail.com

Daniela Prestes

daniprestes@gmail.com

Bárbara Moreschi

bmoreschi@ucs.br

Subprojeto História*

EMEF Presidente Tancredo de Almeida Neves

\section{Introdução}

O ensino sobre povos indígenas americanos ainda constitui um grande desafio em sala de aula. Desinformação, preconceitos, abordagens excessivamente superficiais em livros didáticos e falta de interesse tanto de estudantes como de professores são alguns dos problemas que podem facilmente ser percebidos quando pensamos em trabalhar qualquer questão indígena nas escolas. No campo específico da História, além de tudo, as fontes utilizadas, em parte bastante considerável dos casos, são produzidas por europeus e/ou expressam um olhar eurocêntrico: desenhos, pinturas, diários, relatos de viagens refletem uma visão que muitas vezes não contempla a pluralidade dos diferentes povos indígenas americanos.

\section{Objetivos}

O presente trabalho tem a intensão de refletir sobre a prática pedagógica no ensino dos povos indígenas americanos e pensar em caminhos alternativos ao ensino tradicional, que busquem contemplar a história desses povos de forma menos homogeneizada. Nossa experiência parte de atividades propostas para estudantes do 70 ano do Ensino Fundamental da EMEF Presidente Tancredo de Almeida Neves, em Caxias do Sul, em conjunto com a equipe do projeto do PibidHistória da Universidade de Caxias do Sul. Procuramos adotar um ensino

\footnotetext{
* Subprojeto coordenado pela Profa. Me. Eliane Machado Corrêa Cardoso. Também participaram do projeto as pibidianas Alessandra Cardoso, Maiara Oliveira e Luana Bezerra da Silva.

Supervisor Prof. Me. Paulo Afonso Lovera Marmentini.
} 
"decolonizante", isto é, uma abordagem histórica que priorize um olhar para esses povos e que se distancie do viés eurocêntrico tradicional.

Buscamos, desde o planejamento até a execução das propostas de trabalho em sala de aula, priorizar "a diversidade de civilizações autônomas e de culturas; de sistemas políticos, jurídicos, econômicos, enfim, de organizações sociais, econômicas e políticas construídas ao longo de milhares de anos". (BANIWA, 2006, p. 49). Para isso, procuramos oportunizar momentos de aprendizagem que colocassem os educandos em contato com a cultura material ou imaterial produzida por esses povos nativos, através de imagens, textos, pinturas e objetos arqueológicos. Partimos do princípio de que, analisar e refletir com os alunos a cultura produzida diretamente por esses povos nos liberta, ao menos parcialmente, de uma visão excessivamente eurocêntrica e auxilia na construção de uma visão mais plural e fidedigna sobre os povos indígenas americanos.

\section{Referencial teórico}

Para o desenvolvimento do trabalho, pautamo-nos numa educação "decolonizadora", calcada principalmente na ideia de transgredir projetos centrados no euro (WALSH, 2013; QUIJANO, 2005). "Decolonizar" aparece aqui não como uma visão que ignora a colonização e sua história, mas sim uma nova visão que busca destacar o protagonismo dos povos indígenas americanos e suas diversas facetas, apresentando-se como uma alternativa para o ensino de história mais tradicional.

\section{Período de realização da atividade}

As atividades foram iniciadas com os estudantes a partir de 22 de maio de 2017 e tiveram sequência até o dia 27 de junho do mesmo ano, quando da realização da avaliação sobre o trabalho desenvolvido.

\section{Metodologia e resultados}

A forma tradicional de ensino sobre os povos indígenas americanos, no Ensino Fundamental, é colocá-los cronologicamente após o período das Grandes Navegações e da "Era dos Descobrimentos", denominando-os como "povos pré- 
colombianos". Partimos do princípio de que essa denominação já demonstra um caráter eurocêntrico por si só, pois considera a história dos povos indígenas somente a partir da chegada dos europeus à América. Assim, nossa primeira medida foi inverter essa lógica: abordar primeiro os povos indígenas antes do conteúdo das Grandes Navegações e sem a influência europeia, e procurar apresentá-los como povos autônomos. Isso exigiu uma atenção redobrada ao uso de determinados termos. Falar em povos indígenas sem usar expressões flagrantemente européias, como "pré-colombianos", "descobrimento", "civilização" ou até mesmo em "chegada de europeus", implicou um grande desafio no planejamento das aulas.

Destinamos uma aula para a elaboração de um mapa do continente americano no século XV (portanto, antes da chegada dos europeus), com o objetivo de os estudantes terem um primeiro contato com a diversidade de povos e localizá-los geograficamente. Após, destinamos duas aulas para apresentar com maiores detalhes os povos maia, asteca e inca, dos quais destacamos principalmente as formas de moradia e de elementos arquitetônicos, como forma de expressar a autenticidade desses povos.

Porém, nossa prioridade foi trabalhar com os povos indígenas brasileiros, especialmente os povos que habitaram a Serra gaúcha. Utilizando imagens de escavações arqueológicas realizadas na região e de representações das antigas casas subterrâneas (disponíveis em COPÉ, 2015), procuramos apresentar aos estudantes como os indígenas nativos da região lidavam e vivenciavam a geografia, o clima e a natureza da Serra. Entendemos que, trazendo o objeto de estudo para sua realidade, os educandos podem compreender e se identificar com maior facilidade com o objeto de estudo. Para um estudante do Ensino Fundamental de uma escola de Caxias do Sul, é muito mais didático abordar os indígenas Proto-Jês que habitavam locais familiares a eles, do que abordar indígenas da floresta Amazônica.

Assim, procurando também valorizar as tribos indígenas locais, decidimos desenvolver ainda mais essa abordagem, fazendo um passeio de estudos ao Laboratório de Ensino e Pesquisas Arqueológicas (Lepar) da UCS. Ali, além de aprofundar mais os conhecimentos sobre os indígenas que aqui viveram, os estudantes tiveram a oportunidade de participar de uma oficina de arqueologia, na qual puderam também compreender o ofício do arqueólogo. A avaliação final se deu na semana subsequente, em que o desafio era desenhar o objeto arqueológico escavado e fotografado na oficina de arqueologia e escrever uma 
lauda descrevendo-o: sua forma de fabricação, material de que foi feito, por quem foi feito, para que finalidade, possíveis usos, etc.

\section{Considerações finais}

Na medida do possível, pudemos oportunizar aos estudantes uma forma de compreensão "decolonizada" da história indígena, especialmente dos indígenas que habitaram a Serra gaúcha. Acreditamos que priorizar documentos e fontes produzidas pelos próprios habitantes nativos da América, principalmente fontes arqueológicas, é uma forma de destacar o protagonismo e a complexidade desses povos, evitando o caráter eurocêntrico, tão presente nas formas pedagógicas mais tradicionais. Ainda assim, entendemos que essa abordagem "decolonizada" da História é um grande desafio para a sala de aula, pois implica essencialmente uma mudança de mentalidade não somente dos estudantes, mas principalmente do próprio professor. Acreditamos, por fim, que a atividade docente é um espaço privilegiado para a quebra e o questionamento dessa mentalidade tradicional e que o professor deve sempre promover essa reflexão.

Palavras-chave: Povos indígenas americanos. Ensino de História. Cultura material.

\section{Referências}

BANIWA, Gersem dos Santos Luciano. 0 índio brasileiro: o que você precisa saber sobre os povos indígenas no Brasil de hoje. Brasília: MEC/Secad/Museu Nacional/UFRJ, 2006.

COPÉ, Silvia Moehlecke. A gênese das paisagens culturais do planalto sul brasileiro. Estud. av., São Paulo, v. 29, n. 83, p. 149-171, Apr. 2015.

QUIJANO, A. Colonialidade do poder, Eurocentrismo e América Latina. In: A colonialidade do saber: eurocentrismo e ciências sociais. Perspectivas latinoamericanas. CLACSO, Consejo Latinoamericano de Ciencias Sociales, 2005.

WALSH, C. Introducción. Lo pedagógico y lo decolonial: Entretejiendo caminhos. In: WALSH, C. Pedagógias decoloniales: prácticas insurgentes de resistir, (re)existir y (re)vivir. Quito, Ecuador, noviembre 2013. p. 23-68. Tomo I. (Serie Pensamiento Decolonial). 
32

RETROSPECTIVA DO PIBID-UCS FILOSOFIA: SOMAS, ANSEIOS, PROSPECTIVAS ${ }^{*}$

\author{
Tenisa Zanoto Boeira** \\ Subprojeto: Filosofia \\ Escola Estadual de Ensino Médio São Caetano \\ tenisa.boeira@gmail.com
}

Resumo: Nesse artigo faz-se uma retrospectiva do Pibid-UCS de filosofia e analisam-se os principais trabalhos desenvolvidos e planejados pela equipe de alunos e professores. O Projeto do Pibid Filosofia, desenvolvido na Escola São Caetano, tem como tema "A formação filosófica e a constituição ética do sujeito", no qual procura-se analisar como se dá a aprendizagem moral, a partir do estudo da Ética no ambiente escolar. Várias atividades foram desenvolvidas durante o projeto. Entre elas destaca-se a organização de Oficinas de Ética, que integram um processo de estudos sobre a Filosofia e seu ensino, de maneira lúdica, interacional, através de situaçõesproblema, que permitam analisar de forma crítica, julgar, atribuir valores e emitir juízos fundamentados filosoficamente.

Palavras-chave: Pibid. Filosofia. Relato.

O Pibid-Filosofia UCS iniciou na Escola São Caetano em março de 2014 e encerrou seu ciclo em fevereiro de 2018. Desde então, contou com dois coordenadores, Prof. Dr. Vanderlei Carbonara e Prof. Dr. Luis Fernando Biasoli, 20 bolsistas que atuaram em momentos distintos, atualmente sete e uma bolsista de iniciação científica (Ensino Médio), além da professora supervisora. Esse relato tem como objetivo fazer uma retrospectiva do desenvolvimento das ações do Pibid ao longo desses quatro anos.

Para tanto, como suporte, pretende-se utilizar, como base de pesquisa e observação, o blog utilizado para divulgação do trabalho realizado: $<$ http://filescola.blogspot.com.br/>. Nele, constam diversas informações sobre o pibid, desde a apresentação do grupo de trabalho, tais como coordenador, professora supervisora e equipe de bolsistas, como também todos os Planos de Atividades das oficinas realizadas durante o período de atuação do pibid e, por fim, o histórico das Olimpíadas da Filosofia do Rio Grande do Sul. O blog funciona

\footnotetext{
* Projeto coordenado pelo Prof. Dr. Luis Fernando Biasoli.

** Supervisora do subprojeto Filosofia Professora na EEEM São Caetano, Licenciada em Filosofia, Pós-Graduada em Educação: Supervisão Escolar, Mestra em Letras: Cultura e Regionalidade, pela Universidade de Caxias do Sul, RS.
} 
como um diário, ou seja, todos as atividades desenvolvidas são lançadas nesse espaço. Todos os bolsistas têm acesso. Após a realização das atividades, normalmente, alguns bolsistas escrevem um relato da atividade desenvolvida. Os planos das Oficinas também constam no blog e são descritos de maneira didática, de forma clara, apontando todos os procedimentos da atividade.

\section{Escola}

A Escola Estadual de Ensino Médio São Caetano localiza-se na rua Irmã Geni, 225, Bairro Bom Pastor, na cidade de Caxias do Sul. A instituição oferece o Ensino Fundamental e Médio Politécnico, nos turnos da manhã e tarde.

\section{Projeto}

O subprojeto do Pibid Filosofia, desenvolvido na Escola Estadual São Caetano, tem como tema "A formação filosófica e a constituição ética do sujeito", no qual procura-se analisar como se dá a aprendizagem moral, a partir do estudo da Ética no ambiente escolar.

\section{Oficinas}

Tomou-se por orientação a organização de Oficinas de Ética, que integram um processo de estudos sobre a filosofia e seu ensino, de maneira lúdica, interacional, através de situações-problema, que permitam analisar de forma crítica, julgar, atribuir valores e emitir juízos fundamentados filosoficamente. Durante o tempo de atuação do Pibid, foram realizadas na escola em torno de 40 oficinas, com temáticas e objetivos variados.

\section{Olimpíadas}

As Olimpíadas da Filosofia do Rio Grande do Sul é um evento anual, organizado por uma comissão envolvendo diversas universidades, grupos de professores, estudantes, autônomos de forma voluntária. Normalmente, acontece em dois dias e compreende palestras, oficinas, atividades culturais e recreativas. É destinada a alunos tanto do Ensino Médio, Fundamental como do Ensino Superior. Sua principal característica é o caráter cooperativo e 
colaborativo. As atividades são desenvolvidas a partir de um tema, previamente selecionado e divulgado.

Também é realizada uma etapa regional da Olimpíada, organizada, exclusivamente, pelos bolsistas do Pibid e acontece nas dependências da Universidade de Caxias do Sul. Desde 2014, essa etapa vem ocorrendo seguindo sempre a mesma temática da Etapa Estadual. O evento regional ocorre normalmente 15 a 20 dias antes da etapa estadual. Durante o tempo de atuação do Pibid, foram organizadas as quatro Etapas das Olimpíadas e participamos de três eventos estaduais. Em 2014, o evento ocorreu no Instituto Federal de Osório. Em 2015, ocorreu na Escola Sagrado Coração de Jesus em Bento Gonçalves. Em 2016, na PUCRS, onde deixamos de participar da etapa estadual, por falta de incentivo e verba. Por fim, em 2017, o evento ocorreu na UFRGS, quando estivemos.

\section{Metodologia de trabalho}

No contexto das oficinas e, também, nas Olimpíadas, adotou-se como metodologia de trabalho, preferencialmente, o que propõe Gallo (2007), que prioriza a aproximação aos temas filosóficos de forma simples, partindo do cotidiano, sensibilizando o discente, para que depois se possa problematizar, investigar e, por fim, conceituar os temas propostos.

\section{Considerações finais}

Durante esse tempo de atuação do Pibid na escola, foram desenvolvidas diversas atividades, além das Oficinas; ocorreram projetos de ação social/solidariedade, acompanhamento das aulas e jogos, tal como o RPG Filosófico sobre a Filosofia Clássica. Houve, nesse meio tempo, um amadurecimento de ideias quanto às temáticas desenvolvidas. Inicialmente, todas os trabalhados estavam direcionados ao conceito de Ética. Após algum tempo, o grupo optou por ampliar a temática das oficinas. Logo, apostou-se em trabalhar os filósofos propriamente ditos. Então, na medida que as aulas se desenvolviam, alguns filósofos eram selecionados e planejava-se uma Oficina sobre os temas trabalhados por tal pensador. 
Essa ideia, apesar de fugir da proposta inicial do Projeto do Pibid, trouxe novas possibilidades de trabalho, oportunizando um aprendizado mais amplo e rico, por parte principalmente dos bolsistas, pois os mesmos traziam para as Oficinas o aprendizado que estava acontecendo nas disciplinas cursadas na graduação de Filosofia. Assim, somava-se o aprendizado acadêmico à prática na sala de aula.

O RPG Filosófico também foi uma atividade que possibilitou um aprendizado muito grande, pois o mesmo foi pensado e aplicado em mais de uma turma. Após a aplicação, foi feita uma avaliação do trabalho desenvolvido, e o grupo pôde perceber diversos pontos que poderiam ser melhorados, tais como: texto, parte gráfica que chamasse a atenção do estudante, uma descrição "concreta" dos personagens, mapa detalhado, etc.

Logo, ao avaliarmos o RPG, ideias novas surgiram, a parte gráfica foi pensada, tais como as cenas que apareciam no texto, como a imagem dos personagens, as regras foram melhor definidas, os desafios foram repensados. Desse modo, percebo que houve uma mudança significativa no RPG, pois a qualidade do trabalho cresceu e, quando aplicamos novamente o jogo, observou-se melhores resultados.

Com o tempo, percebemos que mudanças eram necessárias e as adaptações que foram surgindo possibilitaram uma aproximação didáticopedagógica maior entre a Filosofia e o estudante de Ensino Médio. Dar sentido ao que chamamos de conteúdo, utilizar uma linguagem clara e significativa, aproximar-se da realidade do aluno são questões inerentes de toda prática pedagógica eficiente. Aos bolsistas do Pibid, que desfrutaram dessa experiência, somou-se um aprendizado prático sobre a realidade da educação atual, possibilitando o crescimento profissional e humano.

\section{Referências}

CARBONARA, Vanderlei; KUIAVA, Evaldo Antonio. Sobre docência, diálogo e a formação ética: perspectivas de uma educação filosófica. In: CEPPAS, Filipe; RAMOS, Paula; SARDI, Sérgio (Org.). Ensino de filosofia, formação e emancipação. Campinas: Alínea, 2009.

GALLO, Sílvio (Unicamp) / FAVARETTO, Celso (USP) / ASPIS, Lima (Unicamp); Filosofia no Ensino Médio (Coleção 4 DVDs), Produtora: Atta Mídia e Educação, 2007. 
SANGALLI, Idalgo José; CARBONARA, Vanderlei; KUIAWA, Evaldo Antonio. Considerações sobre a aprendizagem da ética a partir de uma leitura hermenêutica da phronesis aristotélica. In: NOVAES, José Luís Corrêa; AZEVEDO, Marco Antônio Oliveira de. A filosofia e seu ensino: desafios emergentes. Porto Alegre: Sulina, 2010. 


\section{Letras Português, Inglês e Pedagogia}

33

ATIVIDADE E UTILIDADE DO GOOGLE DRIVE - RELATO DE EXPERIÊNCIA

Tainá Reis Dorneles

taidorneles@gmail.com

Paula Nicole Scholl Morelato

paulamorelato@gmail.com

Letras Inglês

Escola Estadual de Ensino Médio Santa Catarina

\section{Introdução}

O presente texto tem por objetivo relatar a experiência dos bolsistas do Pibid na Oficina Google Drive para alunos de 1으 e 3 o anos de Ensino Médio, em uma escola pública de Caxias do Sul. Foram necessários dois encontros por turma para a realização da oficina: um para demonstrar a utilização do Drive e outro para a realização da atividade solicitada. A Oficina Google Drive teve o propósito de auxiliar trabalhos em grupo dos estudantes, dentro e fora do ambiente escolar, e teve boa aceitação por parte dos alunos.

Relatamos aqui um projeto desenvolvido pelo Programa Institucional de Bolsas de Iniciação à Docência-UCS, que foi desenvolvido com as turmas de 1 은 ano, 101 e 102 e de 3o ano, 301, 302, 303, 304, 305 e 306, da Escola Estadual de Ensino Médio Santa Catarina, localizada em Caxias do Sul, no mês de junho de 2017. As turmas de 30 ano tinham, aproximadamente, 38 alunos, com idade média de 17 anos e as do 10 , aproximadamente, 34 alunos, com idade média de 15 anos. As aulas tinham duração máxima de 45 minutos e aconteciam duas vezes por semana, conforme o calendário escolar.

\section{Referencial teórico}

Os avanços tecnológicos estão cada vez mais presentes no cotidiano das pessoas. Entretanto, no contexto educacional, este é um assunto relativamente novo. Finardi, Prebianca e Momm (2013, p. 196) afirmam que "cabe aos professores, então, explorar as possibilidades mais conducentes ao pleno 
desenvolvimento humano e social", considerando aspectos sociais, que podem influenciar no contato que jovens estudantes têm com esses avanços. Tais ferramentas, quando aliadas à educação, trazem grandes benefícios aos estudantes, possibilitando desenvolvimento de diversas abordagens e práticas, podendo resultar em um bom desempenho das metodologias aplicadas. De acordo com Finardi, Prebianca e Momm (2013, p.194), "tanto o inglês quanto a internet são linguagens essenciais de inclusão e sobrevivência no mundo plano, globalizado e democratizado em que vivemos". Considerando isso, elaboramos um projeto em que aliamos essas duas linguagens tão presentes na rotina dos alunos, com o objetivo de introduzi-los em um contexto educacional mais tecnológico.

O projeto visou à introdução da ferramenta Google Drive, que é um serviço de compartilhamento e armazenamento de dados via internet. A oficina foi ministrada em português devido ao desnível de conhecimento da língua inglesa, facilitando o aprendizado e beneficiando, também, o trabalho em outras disciplinas. Apesar destes desníveis, não houve maiores dificuldades, pois essas diferenças não foram significativas.

O objetivo foi incitar a curiosidade dos educandos para o uso das ferramentas no Google Drive, construir novos conhecimentos sobre o mesmo, e desenvolver práticas para apresentações em público, podendo ser utilizado, também, para outros tipos de apresentações. A oficina desenvolveu o uso dos recursos, desde os mais básicos aos mais complexos.

Como estudantes de Licenciatura, acreditamos que a tecnologia pode ser uma ótima aliada, se bem-utilizada, para o ensino e para o desenvolvimento de técnicas interativas. Objetivamos, neste projeto, compartilhar com os alunos, passo a passo, de como realizar uma apresentação no Google Drive. A metodologia expositiva, feita através de recursos audiovisuais em laboratório de informática, proporcionou maior familiaridade dos mesmos com a ferramenta. A apresentação baseou-se em uma sequência didática elaborada pelo grupo. 


\section{Descrição da atividade}

Primeiramente, foi solicitado que os alunos acessassem suas contas Google, e os que não a tinham foram instruídos a criar uma conta em casa. A partir desse momento, estes acompanharam a oficina com um colega. A seguir, foram introduzidas as ferramentas principais do menu Google Drive, para que tivessem melhor base para o restante da atividade. Foi explicada a criação de documentos, planilhas, apresentações e compartilhamento de documentos. Foi enfatizado, também, o uso consciente do Google Fotos, chamando a atenção para a necessidade de se manter e respeitar a privacidade, por motivos de segurança.

Após a oficina, através de um tema, os estudantes foram instruídos com relação às utilidades das ferramentas disponíveis como, por exemplo, renomear um arquivo, fazer cópias, tomar conhecimento das configurações da página, fazer edições de texto, inserir gráficos ou figuras, compreender as visualizações de página, formatação, uso de colunas, tabelas e complementos, bem como foram informados que, uma vez que as alterações fossem feitas, seriam salvas automaticamente.

Logo após as explicações sobre a ferramenta, foi solicitada uma atividade em que, além de colocarem em prática o que foi aprendido, também tivessem que trabalhar em grupos e utilizar sua criatividade. A atividade consistiu em uma produção textual, em que foram mostrados objetos aleatórios, e eles deveriam produzir uma história contendo esses objetos. Essa produção textual foi feita de forma colaborativa, isto é, cada um deles deveria criar um parágrafo para a história, de forma alternada. O exercício foi feito em conjunto, utilizando a ferramenta de compartilhamento de documento.

\section{Considerações finais}

Alguns já sabiam como utilizar o Google Drive, o que se tornou bastante interessante, porque houve uma construção de conhecimento colaborativa entre alunos e bolsistas, sendo que os primeiros ajudaram, quando necessário, seus colegas, no decorrer da execução da oficina e/ou da atividade avaliativa. Os estudantes gostaram da proposta e notou-se que utilizaram a ferramenta em 
atividades posteriores. Foi interessante explorar a criatividade, e as histórias incríveis que saíram desse exercício. Além da boa receptividade, tiraram bastante proveito da ideia de aprender algo que poderia facilitar a rotina na escola, futuramente na universidade, e de forma divertida.

Palavras-chave: Pibid. Oficina. Google Drive.

\section{Referência}

INARDI, Kyria Rebeca; PREBIANCA, Gicele Vergine; MOMM, Christiane Fabíola. Tecnologia na educação: o caso da internet e do inglês como linguagens de inclusão. Cadernos do IL, Porto Alegre, n. 46, p. 193-208, jun. 2013. Disponível em: $<$ http://www.seer.urgs.br/index.php/cadernosdoil/article/view/35931/25846>. Acesso em: 1ㅇdez. 2017. 


\author{
Bruna Borges \\ bborges4@ucs.br \\ Susana Souza \\ scspinto@ucs.br \\ Letras Inglês \\ Escola Estadual de Ensino Médio Santa Catarina
}

\begin{abstract}
Resumo: O Halloween é uma data comemorativa importante nos Estados Unidos, país falante da língua inglesa. O projeto Gincana de Halloween foi desenvolvido com base na visão de que aprender a cultura de um povo pode proporcionar melhor compreensão de sua língua e viceversa. Para tal, diversas atividades foram elaboradas e realizadas com os alunos do 30 ano, proporcionando novas aprendizagens de inglês. Na avaliação final, foi possível observar que o resultado foi satisfatório e proporcionou efetiva construção de conhecimento de forma lúdica.

Palavras-chave: Halloween. Cultura. Gincana. Inglês.
\end{abstract}

\title{
Introdução
}

As atividades de Halloween já vêm sendo realizadas há alguns anos, pelos bolsistas do Pibid-UCS Letras-Inglês. Elas têm sido positivas, para alcançar nosso objetivo: construção de novos conhecimentos e revisão de outros na língua inglesa. Acredita-se, também, que a criatividade pode ser uma ótima parceira na motivação de nossos alunos, para a construção de sua autonomia e do conhecimento, o que nos proporciona alcançar nossos objetivos.

Os bolsistas do Pibid, juntamente com a coordenadora Maria Valésia Silva da Silva e a supervisora Marcia Zanbom Farias, se reuniram para planejar uma atividade diferenciada para os alunos. Durante várias reuniões, as atividades foram planejadas e discutidas sob vários aspectos, construindo assim a gincana de Halloween, que foi desenvolvida ao longo do mês de outubro de 2017.

\section{Referencial teórico}

O uso da cultura tem sido cada vez mais utilizado em aulas de língua estrangeira, pela eficácia que tem demonstrado. "As noções de uso da linguagem, comunicação e prática social não podem ser entendidas como fatores 
isolados. Esses fatores estão intimamente ligados à noção de cultura." (SARMENTO, 2001, p. 15).

O objetivo geral da gincana foi analisar os aspectos culturais presentes na festividade de Halloween, favorecendo a motivação para a construção de algumas habilidades básicas na aprendizagem de língua inglesa.

Segundo Santana,

por ser um atributo distintivo, a cultura acaba tornando-se fator determinante de identidade. No entanto, a construção de identidade pode acontecer de diversas formas, principalmente através da linguagem. Isso por ser a língua parte social da linguagem e a linguagem manifestação do comportamento social. (2012, p. 50).

A língua é parte indispensável da cultura de um povo, por isso é importante tomar conhecimento da respectiva cultura, para que o aprendizado possa ser eficaz. É crescente a identificação do valor da cultura em uma sala de aula de língua estrangeira.

\section{Descrição das atividades}

A gincana de Halloween foi desenvolvida em seis turmas de 30 ano do Ensino Médio da Escola Estadual de Ensino Médio Santa Catarina. Os alunos tinham, em média, 16 a 18 anos, e as turmas estavam formadas com cerca de 35 alunos. Todas as turmas, competindo entre si, foram divididas em seis grupos. As atividades ocorreram durante o mês de outubro, utilizando uma aula semanal da disciplina.

$\mathrm{Na}$ primeira semana, as turmas assistiram a um vídeo sobre o mundo cinematográfico de terror. Após, os grupos responderam a um quiz, erguendo plaquinhas para responder às perguntas apresentadas. Na segunda e terceira semanas, os grupos realizaram uma pesquisa, no laboratório de informática, sobre poesias de terror. As bolsistas sugeriram sites específicos, e cada grupo escolheu trechos para produzir um cartaz temático, em que as habilidades de writing e reading foram incentivadas, além de promover a criatividade dos alunos.

$\mathrm{Na}$ quarta semana, os alunos escolheram dois integrantes de cada grupo, preferencialmente um menino e uma menina, para serem maquiados com a 
temática de Halloween. Cada maquiagem deveria ser gravada, a fim de elaborar tutoriais para postagem no YouTube, contendo o áudio ou a legenda em inglês. Os links dos vídeos deveriam ser compartilhados com os bolsistas para fins de pontuação.

$\mathrm{Na}$ última semana, cada grupo participou de uma caça ao tesouro pela escola. Eles receberam as pistas em inglês, deveriam desvendá-las, seguiam as instruções, procurando as próximas pistas a serem entregues ao grupo seguinte. Durante esse tempo, o restante da turma realizava uma atividade com música no laboratório de informática. A música Beauty Underneath, do musical Love Never Dies, foi tocada várias vezes, para que os grupos completassem os espaços na letra impressa que haviam recebido. A maior parte dos grupos foi capaz de acompanhar a letra da música, completando os espaços sem apresentar dificuldades.

No início da gincana, cada turma foi incentivada a fazer um Flashmob, a saber, uma dança temática, durante o intervalo das aulas, para que sua turma recebesse pontos extras. Três turmas realizaram a apresentação. No final da gincana, houve uma festa temática, realizada no dia 31 de outubro. Os alunos se caracterizaram de personagens de terror e participaram das atividades finais da gincana, tentando ganhar seus últimos pontos. Foram, então, anunciados os vencedores e a premiação.

\section{Considerações finais}

No final das atividades, através de uma análise em retrospectiva, foi possível perceber que este projeto alcançou seu objetivo, construção de conhecimento através de uma imersão cultural, explorando uma das maiores expressões culturais dos Estados Unidos, a fim de trazer novos ares para a sala de aula. A língua inglesa foi utilizada em diversos aspectos, incentivando a leitura, a escrita e a compreensão da língua falada.

A maior parte dos alunos demonstrou entusiasmo, participou efetivamente de todas as atividades propostas, divertindo-se ao mesmo tempo. Embora algumas atividades fossem consideradas desafiadoras, que necessitavam de trabalho em equipe e determinação, proporcionaram a construção de habilidades indispensáveis para suas futuras profissões e foram realizadas com 
sucesso. As turmas puderam vivenciar essa cultura da língua inglesa, tendo diversas oportunidades para utilizar seus conhecimentos prévios e boas condições para melhorá-los.

\section{Referências}

SARMENTO, Simone. 0 ensino de cultura na sala de aula de língua estrangeira: 0 discurso e a prática do professor. 2001. 106 f. Dissertação (Mestrado) - Curso de Letras, Universidade Federal do Rio Grande do Sul, Porto Alegre, 2001. Disponível em: $<$ https://www.lume.ufrgs.br/bitstream/handle/10183/69883/000310370.pdf?sequence $=1>$. Acesso em: 20 nov. 2017.

SANTANA, Joelton Duarte de. Língua, cultura e identidade: a língua portuguesa como espaço smbólico de identificação nodocumentário: língua - vidas em português /Language, Culture And Identity: The Portugueselanguage As A Symbolic Identification Space Ondocumentary: Language - Lives In Portuguese. Linha D'Água, São Paulo, v. 25, n. 1, p.47-66, 2012. Disponível em:

<http://www.revistas.usp.br/linhadagua/article/view/37367/40088>. Acesso em: 24 nov. 2017. 


\author{
Marina Bernardo Alves \\ Subprojeto Letras Português - Colégio Estadual Imigrante* \\ mbalves2@ucs.br
}

O presente resumo objetiva uma discussão acerca da mediação da leitura literária em atividades desenvolvidas com alunos do Colégio Estadual Imigrante, durante os anos de 2016 e 2017. O levantamento da realidade feito pelo PibidUCS, em aulas de Língua Portuguesa e de Literatura no Ensino Médio, mostrou que cada vez mais os alunos perdem o gosto pela leitura ou neles se acentua o desgosto por ela. Um fator importante a ser considerado é a falta de leitura de textos canônicos. É indiscutível, no entanto, a importância da mediação da leitura em sala de aula por parte do professor, pois é muito mais fácil desenvolver o gosto por algo lido quando se consegue compreender. Assim, evidencia-se a importância de aprofundar as análises construídas com a turma, de maneira que o sentido do texto não se perca em uma leitura de caráter superficial.

\begin{abstract}
O texto literário é considerado um texto aberto a interpretações, ou seja, não possui um limite pré-determinado em que a imaginação do leitor deve parar. [...] $O$ texto literário é produzido para ser complementado por quem o recebe, isto é, o leitor empírico. A recepção do leitor implica uma ativa participação de sua capacidade de fazer previsões, confirmar ou refutar hipóteses, criticar o que encontra, associar aprendizagens anteriores com as informações que lhe são trazidas pelo texto que se lhe apresenta. $O$ texto literário exige do leitor de texto literário uma atuação sem a qual não se processa a leitura. (FERREIRA, 2007, p. 138).
\end{abstract}

Incentivar essa imaginação também é importante na formação leitora, pois como enfatiza Ferreira (2007, p. 130): “As ideias que surgem a partir da leitura do texto literário são proposições que conduzem de modo geral o leitor a uma profunda e necessária reflexão acerca do que é a vida e de como os desdobramentos da vida se dão." É fundamental, ainda, prestar atenção à relação que se estabelece entre o texto e o leitor:

\footnotetext{
* Coordenadora do subprojeto: Profa. Dra. Suzana Pagot. Supervisora: Profa. Silvete Müller.
} 
Eco (1999) assinala que o leitor é o sujeito que faz com que a máquina (o texto) funcione. Não haverá engrenagem funcionando, caso o operador da maquinaria não acione os botões. No caso, os botões que serão acionados pelo leitor lhe são próprios, intransferíveis e necessários ao texto. Ou seja, a participação do leitor na leitura é condição fulcral para que o texto se movimente, para que o texto ganhe sentido. (FERREIRA, 2007, p. 137).

Nesse ponto, evidencia-se a indiscutível necessidade da presença da literatura na escola. Coelho (2000) ressalta que o espaço da sala de aula é um lugar privilegiado na construção de uma sociedade leitora, além de contribuir com a constituição do sujeito como cidadão:

[...] nesse espaço, privilegiamos os estudos literários, pois, de maneira mais abrangente do que quaisquer outros, eles estimulam o exercício da mente; a percepção do real em suas múltiplas significações; a consciência do eu em relação ao outro; a leitura do mundo em seus vários níveis e, principalmente, dinamizam o estudo e conhecimento da língua, da expressão verbal significativa e consciente - condição sine qua non para a plena realidade do ser. (COELHO, 2000, p. 16).

Desse modo, pode-se comprovar, no desenvolvimento das oficinas, que as questões de pré e pós-leitura são uma estratégia que leva os alunos a construírem reflexões mais aprofundadas sobre a leitura. Quando feitas oralmente, tornam-se uma atividade em que a turma constrói, de forma coletiva, um sentido para o texto. É interessante que o professor organize um roteiro de questões para discussão antes e depois da leitura. As questões de pré-leitura têm a função de preparar um cenário para os leitores, contribuindo na contextualização do texto, com indagações direcionadas a diferentes hipóteses sobre o tema, o contexto de produção, o autor e as inferências a partir do título. Além disso, essa primeira parte da atividade cria expectativas que podem ou não ser confirmadas durante a leitura. Entretanto, é necessário que se observe a construção de questões abertas que propiciem multiplicidade de caminhos e incitem a curiosidade e o interesse.

Já as questões de pós-leitura têm por função justamente a discussão dos sentidos que foram construídos durante a leitura, aprofundá-los e expandi-los o máximo possível. Assim como nas questões de pré-leitura, nessa etapa, é preciso ter cuidado redobrado, para que a condução da interpretação não seja uma síntese do pensamento do professor em detrimento das possibilidades vislumbradas pelos alunos. 
Dessa forma, essa atividade contribui para a compreensão e para que, individualmente, cada aluno possa interpretar de forma mais abrangente e, assim, aprofundar suas próprias análises. $O$ texto literário é um campo aberto a interpretações, que "deve ser explorado em seus diversos matizes para que a sensibilidade do aluno seja despertada, e ele possa ler e apreciar adequadamente essa obra, transformando-se em um leitor assíduo, o que vai possibilitar ao jovem enriquecer sua vivência e tornar-se um leitor autônomo". (SANTOS; ZINANI, 2012, p. 45).

É importante que o professor, não se prendendo a materiais prédeterminantes de seu fazer pedagógico, proporcione esses momentos de interação e construção coletiva de sentido do texto literário. Atualmente, as teorias pedagógicas valorizam o ato de dar voz ao aluno. A aula de literatura é um momento em que essa exposição é necessária e produtiva. É uma reconquista da autoestima do aluno, apagada pelos conceitos de certo e errado, que busca justamente desenvolver as capacidades não só de análise crítica, mas de argumentação.

Assim, pelas experiências vivenciadas no projeto, percebeu-se que o papel do professor-mediador tem profunda importância na formação de alunos leitores, tanto no planejamento das atividades como na seleção de textos, levando em consideração não apenas os canônicos, mas também variados textos que contribuam para a evolução leitora dos alunos. Nem sempre eles estarão habituados a leituras complexas, daí a necessidade de o professor intervir de maneira a levar o próprio aluno a construir inferências sobre o texto lido.

\section{Referências}

COELHO, Nelly Novaes. Literatura infantil: teoria, análise, didática. São Paulo: Moderna, 2000.

FERREIRA, HUGO M. A literatura na sala de aula: uma alternativa de ensino transdisciplinar. Universidade Federal do Rio Grande do Norte: Natal, RN, 2007. Disponível em: <ftp://ftp.ufrn.br/pub/biblioteca/ext/bdtd/HugoMF.pdf> . Acesso em: 12 nov. 2017.

SANTOS, Salete Pezzi dos; ZINANI, Cecil Jeanine Albert. Ensino da literatura: pressupostos teóricos. In: ZINANI, Cecil J. A. (Org.). Transformando o ensino de língua e literatura: análise da realidade e propostas metodológicas. 2. ed. Caxias do Sul: Educs, 2012. 


\author{
Anna Carolina Pasquali \\ acpasquali@ucs.br \\ Raissa Lauana Antunes da Silva \\ rlasilva@ucs.br \\ Pibid Letras Português* \\ Colégio Estadual Imigrante
}

A perspectiva da escola, como espaço de emancipação de sujeitos, toma por base as noções de escola como locus dialético, no qual a teoria e a sociedade caminham em consonância. Buscando corroborar essa perspectiva, o presente resumo expandido objetiva relatar a experiência do uso da Literatura de forma emancipatória, fundamentando sua importância nesse processo de independência, relacionando literatura e sociedade nas oficinas desenvolvidas no Pibid-UCS, no subprojeto Letras Português, em 2017.

Freire (1967) inicia suas reflexões sobre a educação afirmando que o papel do sujeito na sociedade não é somente estar presente no mundo, mas viver com o mundo. Enquanto existimos, estamos em um processo contínuo de criação e recriação, seja de nós mesmos, seja da sociedade. A realidade é que a reconstrução é algo natural para o ser humano, ou ao menos deveria ser e, além do que já existe na nossa natureza, estamos constantemente criando o que Freire (1967) chama de "realidade cultural."

Entendemos que, para o homem, o mundo é uma realidade objetiva, independente dele, possível de ser conhecida. É fundamental, contudo, partirmos de que o homem, ser de relações e não só de contatos, não apenas está no mundo, mas com o mundo. Estar com o mundo resulta de sua abertura à realidade, que o faz ser o ente de relações que é. (FrEIRE, 1967, p. 39).

Mas o que é essa realidade cultural? Na verdade, ela nada mais é do que a relação do sujeito com o mundo, ou até mesmo, como Freire (1967) afirma, uma

\footnotetext{
${ }^{*}$ Coordenadora do subprojeto: Profa. Dra. Suzana Pagot. Supervisora: Profa. Silvete Müller.
} 
relação do sujeito com o objeto. Essa relação resulta em um conhecimento que será expresso por meio da língua.

Segundo Freire (1967), este processo - interagir com o mundo e o reconstruir constantemente - não é algo reservado apenas para indivíduos alfabetizados. Somos todos capazes de fazê-lo, alguns de forma consciente, outros não. Considerando que estamos em constante ação e reação com o mundo, a consciência crítica é um fator determinante, para que possamos ser agentes eficazes do mundo, para que tenhamos uma consciência ativa com a realidade, e não simplesmente fiquemos acomodados à realidade na qual vivemos.

Por isso, desde já, saliente-se a necessidade de uma permanente atitude crítica, único modo pelo qual o homem realizará sua vocação natural de integrar-se, superando a atitude do simples ajustamento ou acomodação, apreendendo temas e tarefas de sua época. (FREIRE, 1967, p. 44).

Para que tenhamos uma sociedade engajada criticamente, a educação também deve seguir essa premissa, visto que ela é um dos únicos meios capazes de apresentar a realidade crítica ao sujeito e ensiná-lo como se posicionar.

A literatura sozinha já carrega uma ampla carga de criticidade, expandido a possibilidade de trabalho do docente. Ler significa unir o texto com os conhecimentos extratextuais, portanto, agir ativamente no ato de ler, assim como na sociedade que cerca o leitor. Precisamos debater as formas como a literatura é levada para a sala de aula, assim como levar o aluno a questionar o que aprender, como aprende e por que aprende, de modo que ele entenda que o texto, a leitura, é mais do que apenas algo abstrato, tornando-o concreto e possível de ser utilizado na sua relação com o mundo.

Visando à tomada de consciência leitora por parte dos alunos do 3ㅇan ano, implementou-se a oficina "O que é o mundo?", cujo objetivo era levar a uma reflexão sobre a realidade na qual os alunos estão inseridos e as múltiplas realidades existentes. Para isso, foram usados textos literários sobre as diferentes perspectivas do mundo, promovendo a leitura de três contos: "Tia Cristina", de Angeles Mastretta; "No retiro da figueira", de Moacyr Scliar, e "Ideias do Canário", de Machado de Assis.

Para Cavalcanti (2002), a leitura permite que o mundo seja conhecido e compreendido, tornando-nos mais sensíveis e empáticos em relação à realidade do outro: 
Ler sempre representou uma das ligações mais significativas do ser humano com o mundo. Lendo reflete-se e presentifica-se na história. O homem, permanentemente, realizou a leitura do mundo. Em paredes de cavernas ou em aparelhos de computação, lá está ele reproduzindo seu "estar-nomundo" e reconhecendo-se capaz de representação. Certamente, ler é engajamento existencial. Quando dizemos ler, nos referimos a todas as formas de leitura. Lendo, nos tornamos mais humanos e sensíveis. (CAVALCANTI, 2002, p. 13).

A oficina foi enriquecedora, permitiu que os alunos notassem as diferentes visões de mundo de cada escritor, de diferentes culturas e até mesmo sua própria visão de mundo. A partir desses textos, assim como dos debates promovidos, os alunos do 3ㅇ ano do Ensino Médio do Colégio Imigrante questionaram sua própria relação com o mundo, o quão influenciados são pela cultura, pela mídia, o que consideravam certo e errado, e suas atitudes frente ao mundo em que vivem. A oficina e os debates realizados possibilitaram que os alunos percebessem que o mundo é relativo, e que cada um o vê de maneira diferente.

\section{Referências}

FREIRE, Paulo. Pedagogia do oprimido. Rio de Janeiro: Paz e Terra, 1980.

FREIRE, Paulo. Educação como prática de liberdade. Rio de Janeiro: Paz e Terra, 2009.

CAVALCANTI, Joana. Caminhos da literatura infantil e juvenil: dinâmicas e vivências na ação. São Paulo: Paulus, 2002. 


\title{
37 \\ RELAÇÕES POSSÍVEIS ENTRE AS EXPERIÊNCIAS NO PIBID E AS PRÁTICAS EM ESTÁGIO DOCENTE
}

Jasmine Cristina Busetti

Subprojeto Letras Português Colégio Estadual Imigrante* jasminebusetti@gmail.com

O presente resumo tem por objetivo refletir sobre a relação entre os estágios obrigatórios supervisionados e as práticas vivenciadas no subprojeto Letras Português do Programa Institucional de Bolsa de Incentivo à Docência (Pibid), desenvolvido na Universidade de Caxias do Sul, em parceria com a Capes e realizado no Colégio Estadual Imigrante, sob a supervisão da Profa. Silvete Müller e coordenação da Profa. Dra. Suzana Pagot, no ano de 2017.

O curso de graduação proporciona uma experiência efetiva entre a aprendizagem na graduação e a atuação no campo de trabalho, e isso se dá pelo estágio obrigatório. Essa vivência, em muitos casos, é determinante para a decisão profissional, como destacam Silva e Teixeira:

\begin{abstract}
A transição da universidade para o mercado de trabalho abarca um período crítico de construção de sentidos sobre si mesmo com importantes repercussões para o futuro, uma vez que as primeiras experiências de inserção no mundo do trabalho são capazes de influenciar padrões futuros de carreira. (SILVA; TEIXEIRA, 2013, p. 104).
\end{abstract}

Além disso, são também destacados por Silva e Teixeira (2013) alguns aspectos que afirmam que os alunos engajados em estágios apresentam alguns indicadores positivos no desenvolvimento da carreira. Isso se dá pelo fato de que o estágio serve como uma aproximação real do mundo do trabalho, "contribuindo para o desenvolvimento de competências transversais (ou seja, não técnicas, tais como responsabilidade, autonomia) e para uma adequação mais realista das expectativas dos estudantes frente ao trabalho". (SILVA; TEIXEIRA, 2013, p. 105).

\footnotetext{
${ }^{*}$ Coordenadora do subprojeto: Profa. Dra. Suzana Pagot. Supervisora: Profa. Silvete Müller.
} 
Mais especificamente quando se trata do estágio nos cursos de licenciatura, essa prática de assumir a rotina de um professor faz com que o futuro profissional da área consiga, de maneira prática, associar e compreender a rotina da profissão. Assim, "o estágio pedagógico é aqui entendido como palco de um dos processos mais ricos e decisivos da capacitação e da integração do jovem professor, no mundo da docência e no mundo adulto". (CAIRES, 2006, p. 89).

Estudos apontam que, o final de experiências positivas de estágio, o aluno consegue desenvolver melhor confiança perante uma turma e, também, em muitos casos, apresenta uma certeza à sua real "vocação" para a profissão docente. Entretanto, para se chegar a esse resultado, períodos de tensão, de ansiedade fazem com que o início dessa experiência seja complicada e traumatizante, justamente pelo fato de não possuir essa experiência em sala de aula.

A partir dessas reflexões, é possível estabelecer a relação entre as experiências nas práticas dos estágios supervisionados e aquelas vivenciadas durante as atividades no Pibid, criado a partir do pressuposto de desvincular a dicotomia estabelecida entre ensino/pesquisa/extensão, criando e proporcionando "aos acadêmicos dos cursos de licenciatura o resgate do valor de ser professor em contexto de transformações contínuas que abrem novas interrogações sobre os fundamentos do vínculo social". (Pibid, 2013). O aluno de licenciatura que entra em contato com o projeto recebe a oportunidade de vivenciar a carreira docente de forma prática e ao mesmo tempo teórica. Consegue também, por meio dele, ir aos poucos perdendo o receio e ganhando confiança tanto na profissão quanto em si mesmo.

A ideia do projeto parte, justamente, dessa intenção de preparar o estudante de licenciatura, proporcionando o momento de interação e aprendizagem. Esse movimento, além de proporcionar ao estudante a oportunidade de conhecer a realidade escolar, contribui também com o diálogo estabelecido entre a universidade e os espaços escolares, fazendo com que essa divisão entre teoria e prática seja cada vez menos definida por polos distintos e cada vez mais complementar.

Assim, quando o pibidiano entra em estágio, sua experiência anterior na sala de aula proporciona ao aluno de licenciatura uma confiança muito maior no 
momento de atuar como professor, visto que o projeto já Ihe proporcionou ser o protagonista da ação de aprender, além de ter a oportunidade de discutir, propor e negociar questões que envolvem a aprendizagem e o ambiente escolar em si.

É importante também ressaltar que, como a primeira experiência do pibidiano em sala de aula se dá de forma mais informal, que na do estágio, o nível de tensão não é tão drástico e estressante. Outro ponto que faz com que o primeiro contato seja mais fácil é o fato de não estar sozinho. Os momentos do Pibid com os alunos normalmente acontecem coletivamente e isso facilita a ação pedagógica do bolsista. A confiança e as construções em parceria, os momentos de avaliação, a análise das atividades satisfatórias e a reflexão sobre aquelas que não tiveram êxito propiciam um amadurecimento intelectual, profissional e pessoal, desdobrando-se em segurança e um sentimento de acolhida.

Assim, é possível concluir que, apesar da experiência de passagem do processo de aprendizagem da teoria, vivenciado na universidade, para o campo de trabalho ser ao mesmo tempo inquietante e desafiadora, quando esse processo é permeado pelas vivências na iniciação docente proporcionada pelo Pibid, é possível agregar maior grau de qualidade e eficência nas práticas dos estágios. Dessa forma, o Pibid apresenta um caráter de divisor de águas na eficácia para a formação docente.

\section{Referências}

CAIRES, Susana. Vivências e percepções do estágio pedagógico: contributos para a compreensão da vertente fenomenológica do "Tornar-se professor". Análise Psicológica, Lisboa, v. 24, n. 1 , p. 87-98, 2006. Disponível em: <http://publicacoes.ispa.pt/index.php/ap/article/view/156/pdf>. Acesso em: 12 set. 2017.

SILVA, C. S. C.; TEIXEIRA, M. A. P. Experiências de estágio: contribuições para a transição universidade-trabalho. Paidéia, v. 23, p. 103-112, 2013.

UCS. Pibid-UCS. Disponível em: <https://www.ucs.br/site/graduacao/pibid/pibid-ucs/>. Acesso em: 12 set. 2017. 


\author{
Fabiana Pastore Consorte* \\ fabypastore46@gmail.com \\ Jeniffer Maciel Giordano* \\ jenigior@gmail.com \\ Marcela Lopes* \\ panda.marcela2312@gmail.com \\ Taís Zanella Bortolon* \\ tzanella1992@gmail.com \\ Subprojeto: Pedagogia - Camva* \\ EMEF Juventina Morena de Oliveira
}

Resumo: Este relato tem como objetivo compartilhar as experiências e reflexões nas atividades do subprojeto Pibid/Pedagogia UCS-Camva, realizadas na escola no ano 2017. O projeto foi desenvolvido na escola situada no Bairro Barcelos, na periferia, onde a pobreza e a violência estão presentes, com muitas famílias oriundas de outras localidades, que vêm para trabalhar nos pomares da região e aí permanecem. A turma atendida foi a do 4으 ano do Ensino Fundamental, com um histórico de repetências. Buscou-se inicialmente um referencial teórico-metodológico, seguindo de estudo de caso de cada aluno e suas dificuldades de aprendizagens, seu histórico familiar, relacionamento com a sociedade/comunidade e como eles se vêm nelas, culminando com a montagem de um livro com as atividades realizadas pelos alunos.

\title{
Introdução
}

O Pibid visa agregar conhecimentos na vida dos licenciandos, aliando a teoria com a prática, aproximando-os da realidade da escola, pondo em prática suas aprendizagens e aprimorando sua formação docente.

Percebe-se a importância do processo de ensino e aprendizagem para a compreensão e valorização da cultura escrita na escola, bem como a necessidade de contextualizar/adequar o currículo para despertar e motivar discentes em situação de vulnerabilidade social e histórico de reprovações, para que ampliem as aprendizagens necessárias para a sua vida cidadã. Pensou-se trabalhar um projeto que elevasse a autoconfiança dos educandos, despertando o prazer de ler, escrever e aprender.

\footnotetext{
${ }^{*}$ Bolsistas Pibid.

${ }^{* *}$ Coordenadora do subprojeto: Profa. Me. Olivia Mélo da Silva.E-mail: omsilva@ucs.br Supervisora: Profa. Márcia de Aguiar Constante. E-mail: marciaaguiarconstante@gmail.com
} 


\section{Referencial teórico}

Buscou-se referências que contribuíssem para entender a realidade dos educandos e ajudá-los no seu "direito ao desenvolvimento e às aprendizagens". O educador Paulo Freire afirma:

Respeitar a leitura de mundo, do educando, não é também um jogo tático com que o educador ou educadora procura tornar-se simpático ao educando. É a maneira correta que tem o educador de, com o educando e não sobre ele, tentar a superação de uma maneira mais ingênua por outra mais crítica de inteligir o mundo. Respeitar a leitura de mundo do educando significa tomá-la como ponto de partida para a compreensão do papel da curiosidade, de modo geral, e da humana, de modo especial como um dos impulsos fundantes da produção do conhecimento. (FREIRE, 1996, p. 122123).

Como ponto de partida é fundamental respeitar o educando e com ele buscar uma compreensão mais aguçada no campo do conhecimento escolar, para melhor ler o mundo a sua volta e num contexto mais amplo.

Nesta busca, para auxiliar os educandos e entender o seu contexto, o pesquisador Arroyo também contribuiu, com seus estudos sobre "qual currículo serve para quem lhes foi roubada a humanidade?" E faz um alerta dizendo que estes trazem para a escola uma cultura ativa:

Se reconhecemos que carregam uma cultura ativa, o ponto de partida será o que desde crianças menores fazem, sentem, pensam para sobreviver, se defender de maus-tratos, para se proteger, cuidar reagindo a tanta desproteção. Cultura ativa para se afirmar sujeitos de direitos frente a tantos negados. Mobilizar didáticas de participação em todas as atividades educativas, em pesquisas, diálogos, produções. A forma mais radical de participação se dará por reconhecer seu acúmulo de vivências e de reações a seu indigno e injusto viver. (ARROYo, 2011, p. 257).

Estas ideias animaram o grupo a refletir e pensar práticas didáticas, considerando os alunos como sujeitos de direitos humanos e de aprendizagem, que lhes permitam usufruir dos bens produzidos pela humanidade, contribuindo assim para que possam resgatar o direito à uma vida digna e justa. 


\section{Descrição da atividade}

A experiência ocorreu de agosto a dezembro de 2017, na EMEF Juventina Morena de Oliveira, desenvolvida no 4ㅇ ano A, na qual era regente a Profa. Márcia de Aguiar Constante, também supervisora do Pibid.

Os alunos entre 9 e 12 anos de idade, dois deles com diagnóstico de deficiência intelectual, todos com dificuldade de leitura fluente, escrita e interpretação de texto, inclusive com alguns recém-alfabetizados e muitos repetentes, moram em residências com precárias condições de luz, água e saneamento. Alguns freqüentam, no turno inverso, o Novo Mais Educação, com programas de reforço escolar, oficinas de dança e música. Nas famílias, vindas de outros locais, incluindo indígenas, alguns conseguem se estabilizar, outros são itinerantes. São oriundos de diversas composições familiares nas quais, às vezes, o relacionamento é complicado, envolvendo violência doméstica, violência de gênero, violência física e sexual, crianças com pais ausentes, criadas pelos avós.

Diante dessa realidade, pensou-se uma proposta de intervenção pedagógica interdisciplinar, com a composição de um livro das atividades realizadas.

\section{Objetivo geral}

- Oportunizar aos educandos a compreensão e valorização da cultura escrita.

\section{Objetivos específicos}

- conhecer a origem do seu nome;

- entender a genealogia de seu grupo familiar;

- compreender e dominar o processo da leitura e da escrita;

- confiar no seu potencial para criar/produzir textos;

- reconhecer diferentes gêneros textuais;

- valorizar a cultura escrita;

- conhecer e valorizar os espaços de aprendizagens do campus da UCS/Camva e deles usufruir.

\section{Atividades}

- pesquisa do nome; 
- construção da árvore genealógica;

- atividade no espelho e autorretrato;

- contação de histórias;

- visita e utilização dos espaços de aprendizagens da UCS;

- produção de relatórios.

\section{Critérios de avaliação}

- Leitura fluente de diversos gêneros textuais; compreensão e interpretação dos textos lidos; qualidade da produção textual; leitura de e-mails e respostas pertinentes; participação ativa e frequente nas aulas.

\section{Considerações finais}

Esta proposta oportunizou às bolsistas uma experiência docente significativa, aliando teoria e prática.

Com o projeto desenvolvido, foi possível perceber, pelos critérios de avaliação adotados, que os alunos desenvolveram autoconfiança, o gosto pela leitura, a produção textual, a comunicação oral e escrita e perspectivas nos estudos.

Os objetivos de aprendizagens foram alcançados, permaneceu na turma um aluno infrequente, os demais foram aprovados.

Ficou claro que o papel do professor, como mediador no processo de aprendizagem, é fator decisivo para o desenvolvimento integral do educando, oportunizando ao mesmo aprender, gostar e permanecer na escola.

Palavras-chave: Aprendizagem. Leitura. Escrita. Experiência.

\section{Referências}

ARROYO, Miguel G. Currículo, território em disputa. Petrópolis, RJ: Vozes, 2011.

BRASIL. Ministério da Educação. Coordenação de Aperfeiçoamento de Pessoal de Nível Superior (Capes). Portaria № 096/2013.

FREIRE, Paulo. Pedagogia da autonomia: saberes necessários à prática educativa. São Paulo: Paz e Terra, 1996.

FURASTÉ, Pedro Augusto. Normas técnicas para o trabalho científico: especificação das Normas da ABNT. Porto Alegre: Dáctilo Plus, 2012. 
39

\title{
RELATO E ANÁLISE DE EXPERIÊNCIA DA OFICINA DO ENEM
}

\author{
Thais de Oliveira* \\ lang.thais@gmail.com \\ Camila Fin Martins \\ camilafinmartins33@gmail.com \\ Subprojeto Letras Inglês \\ Escola Estadual de Ensino Médio Santa Catarina
}

Resumo: Em razão da grande dificuldade e necessidade dos alunos para se prepararem para as provas do Exame Nacional do Ensino Médio (Enem), foi elaborada e oferecida a OFICINA DO ENEM, realizada pelos bolsistas do Pibid, com o suporte da supervisora escolar e enfatizando as questões de Língua Estrangeira.

Palavras-chave: Enem. Linguagem. Língua estrangeira. Oficina.

\section{Introdução}

A oficina do Enem objetivou ajudar os alunos do 3ㅇ ano a se prepararem para as questões de Língua Estrangeira, no Exame Nacional do Ensino Médio. Ela teve como enfoque temas e conteúdos mais relevantes para a realização da prova. No ano de 2017, este projeto foi aplicado para seis turmas que estavam cursando o último ano do Ensino Médio da escola Estadual de Ensino Médio Santa Catarina.

O Exame Nacional do Ensino Médio (Enem) é uma prova realizada anualmente em todo o Brasil, para avaliar o desempenho dos estudantes da rede pública e privada do ensino médio.

A nota da prova do Enem é utilizada como critério de seleção para os estudantes que visam a uma bolsa no Programa Universidade para Todos (ProUni); para participar do Sistema de Seleção Unificada (Sisu), programa do governo federal, que classifica candidatos a uma vaga em universidades públicas e pode ser usada também para o Fies, o financiamento do governo federal, que ajuda a pagar a faculdade privada.

A oficina foi planejada durante as reuniões semanais do Pibid. Foram feitos treinamentos com os bolsistas para a prática das apresentações. Eles foram

\footnotetext{
${ }^{*}$ Bolsistas Pibid.
} 
assistidos pela coordenadora e supervisora do Pibid, e estas deram dicas e sugestões para uma apresentação mais dinâmica e interativa.

A realização do projeto teve a duração de duas semanas, utilizando de três a quatro períodos da disciplina de Língua Inglesa. No ano de 2017, ele teve início no mês de setembro, com o envolvimento de todos os bolsistas e professores responsáveis.

Durante a realização da sequência didática, com o auxílio de slides, foram apresentados aos alunos o formato das provas, gráficos de desempenho dos candidatos em Língua Estrangeira (Inglês e Espanhol) e os vocabulários fundamentais para a realização da prova, além de estratégias de leitura, ferramentas gratuitas para estudar Inglês e dicas sobre o dia da prova.

No vocabulário apresentado, os seguintes assuntos foram comentados: palavras transparentes, falsos cognatos, palavras-chave e prefixos e sufixos. Nas palavras transparentes foi mostrado aos alunos que há muitos vocábulos em inglês que possuem a grafia igual, ou muito parecida, com o que usamos na língua portuguesa e tendo o mesmo significado, mas não a mesma pronúncia. Os alunos deram diversos exemplos utilizados no cotidiano como "chocolate", "hamburger" e "hospital".

Falsos cognatos são palavras que nos remetem a um significado, quando, na verdade, ele é totalmente diferente. As palavras push (empurrar) e pull (puxar) são exemplos muito utilizados, pois ao ler a palavra push a maioria das pessoas pensa, automaticamente, na palavra puxar, sendo que o real significado do vocábulo é empurrar, ou seja, o oposto. Foi mostrado um vídeo sobre o assunto, para ajudar na explicação. Na sequência, foi solicitado aos alunos que dessem outros exemplos de falsos cognatos, e várias palavras surgiram. Eles demonstraram grande interesse neste assunto, pois os mesmos comentaram e relataram sobre situações, às vezes constrangedoras, que já haviam passado, por não saberem o significado correto de alguma palavra.

O próximo assunto abordado foi prefixos e sufixos. Foi dada uma explicação sobre a diferença gramatical de cada um, além de exemplos e exercícios relacionados. Foram feitas comparações entre a gramática utilizada na Língua Portuguesa e na Língua Inglesa para um melhor entendimento por parte dos alunos. 
Após, foram apresentadas cinco estratégias de leitura, retratadas por Amadeus Marques em sua obra Inglês para o Enem:

2 Skimming: trata-se de uma leitura rápida do texto, uma leitura geral sobre o assunto;

3 Scanning: utilizada para a localização de informações específicas;

4 Finding the topic sentence: frases apresentam a ideia principal do texto;

5 Making inferences: quando se faz a leitura nas entrelinhas, ou seja, interpretação de texto;

6 Getting meaning from context: há a linguagem não verbal e as palavraschave.

Foi possível observar grande interesse, por parte dos alunos, durante a apresentação da oficina, principalmente quando foi falado sobre as oportunidades gratuitas para estudar uma língua estrangeira, através de canais do YOUTUBE, do Site do British Council Learn English, EnglishLessons4U e ESL Basics. Foram apresentados, também, aplicativos que podem ser utilizados para aprendizagem, de maneira gratuita: Duolingo e LinguaLeo e sites brasileiros que também podem auxiliar no aprendizado, tais como: English Experts, Inglês Gratuito e Tecla Sap.

No final da apresentação da oficina, foram dadas dicas aos alunos sobre o que levar no dia da prova, e o que não levar, além de lembrá-los sobre as datas e os horários das provas.

\section{Considerações finais}

Após a apresentação da oficina, foi possível perceber que os alunos adquiriram maior confiança na leitura e na interpretação de texto, para a realização da prova, em especial a parte de língua estrangeira, podendo melhor se preparar para o exame, tirando dúvidas e utilizando os sites e aplicativos de forma mais autônoma. No final, programou-se fazer o simulado online no laboratório de informática, mas, infelizmente, não foi possível realizar, devido à greve do magistério. Desta forma, foi solicitado aos alunos que o realizassem como tarefa e fizessem a conferência conforme gabarito. 


\section{Referências}

MARQUES, Amadeu. Inglês para o Enem: guia de estudo com respostas e comentários. Barueri - SP: Disal, 2015.

LOURENÇO, Ana. Como estudar linguagens, códigos e suas tecnologias para o Enem. 26 jun. 2012. Disponível em: <https://guiadoestudante.abril.com.br/enem/como-estudarlinguagens-codigos-e-suas-tecnologia s-para-o-enem/\#/>. Acesso em: 16 ago. 2017.

CONHEÇA o Enem. 9 ago. 2017. Disponível em: <enem.inep.gov.br/\#/antes?_k=z3ursr>. Acesso em: 26 ago. 2017.

REDAÇÃO Mundo Vestibular. Para que serve o Enem?. 2017. Disponível em: $<$ https://www.mundovestibular.com.br/articles/18061/1/Para-que-serve-oEnem/Paacutegina1.html>. Acesso em: 26 fev. 2018. 
40

UMA PROPOSTA PARA O ESTUDO DE GÊNEROS TEXTUAIS

SUBPROJETO PIBID-UCS CARVI LETRAS PORTUGUÊSI ${ }^{\#}$

\author{
Camila Fernanda Ferreto Jaques \\ ferretocamila@gmail.com \\ Subprojeto de Letras Português - Carvi \\ Escola Estadual de Ensino Médio Mestre Santa Bárbara
}

\title{
Introdução
}

O subprojeto do curso de Letras da Universidade de Caxias do Sul (UCS), Campus Universitário da Região dos Vinhedos (Carvi), atuou com propostas direcionadas a turmas do 20 e do 30 ano do Ensino Médio da Escola Estadual de Ensino Médio Mestre Santa Bárbara, em Bento Gonçalves. Em 2017, os encontros ocorreram no turno regular de aula.

As atividades foram desenvolvidas sob a coordenação da Profa. Ma. Odete Maria Benetti Boff, tendo como fundamentação teórica os conhecimentos construídos no curso de Letras. Dessa forma, os bolsistas elaboraram planejamentos e materiais de trabalho alinhados aos aprendizados do curso e, ao mesmo tempo, às demandas da escola.

De março a julho de 2017, o público-alvo compreendeu os $30_{s}$ anos do Ensino Médio e, de agosto a dezembro, os 2ㅇs anos. Em todas as turmas, foram propostas atividades de leitura e de escrita, de modo que as necessidades observadas e apontadas pelos alunos pudessem ser solucionadas.

\section{Foco nos gêneros textuais}

Os planos de unidade desenvolvidos ao longo do ano tiveram o foco direcionado a dois gêneros textuais específicos, a fim de que os estudantes ampliassem seus conhecimentos acerca das funções e das características de textos que circulam socialmente, ou seja, crônica não literária e dissertação

\footnotetext{
\# Trabalho desenvolvido sob orientação da coordenadora do subprojeto Letras Português do Carvi, Profa. Mạ. Odete Maria Benetti Boff.

Bolsista Pibid.
} 
escolar. De acordo com Pereira et al. (2006, p. 29), o aluno já possui algumas noções sobre as singularidades dos gêneros textuais, uma vez que ele é usuário da língua. O papel da escola é formalizar esse conhecimento, a fim de ampliar a competência comunicativa do educando, tornando-o apto para interagir em quaisquer situações. Assim, "na sua prática docente, o professor deve desenvolver no aluno competências que o levem a reconhecer que a pluralidade de discursos contribui para o desenvolvimento da sua autoestima, seu sentido de cidadania e seu papel social".

Nessa perspectiva, outros gêneros, como poemas, letras de músicas e textos jornalísticos também foram abordados em atividades complementares, suscitando a circulação de materiais que permitissem a fruição da subjetividade e intersubjetividade, considerando que os potenciais linguísticos estão ligados às condições interativas disponibilizadas para os sujeitos. A partir, portanto, de textos variados, realizaram-se práticas de leitura, compreensão e interpretação. Além disso, ocorreram reflexões e debates sobre os temas emergentes e análises das especificidades das produções textuais.

Pela proposta, portanto, previu-se ler para interagir com os gêneros lidos, mobilizando os conhecimentos prévios e as opiniões construídos ao longo da vida do estudante. As mais variadas ações sempre estiveram alicerçadas no objetivo de ampliar o pensamento crítico dos alunos, levando-os a refletirem sobre os temas envolvidos nos textos e a se posicionarem sobre os mesmos. "A leitura não é algo passivo, ela depende da interação texto-leitor, momento também em que o leitor e o autor se aproximam por meio do texto". (BRAGA; SILVESTRE, 2002, p. 21).

Em relação à análise das características dos gêneros textuais, também foi considerado o aspecto da interação entre produtor e receptor, que se estabelece em situações específicas. Assim, foram observados os aspectos apontados por Braga e Silvestre (2002): tempo e lugar; relação entre os interlocutores; características e papel social do enunciador e do receptor; objetivos da interação; canal / veículo; grau da formalidade da situação.

No caso do gênero crônica não literária, por exemplo, foi solicitado que os estudantes verificassem a data e o local da publicação, compreendendo a relação entre o texto, o contexto social e histórico de sua inserção, bem como os fatos que motivaram a sua produção. As crônicas jornalísticas foram 
apresentadas, a partir de seus respectivos periódicos de suporte, a fim de observar as características do veículo de comunicação e, com isso, supor seus possíveis leitores, identificar o autor do texto e sua função no periódico, analisando os propósitos e o grau de formalidade da publicação.

No final do trabalho, os alunos chegaram a conclusões sobre o gênero crônica, sendo algumas delas: a liberdade temática do gênero; a existência ou não de prazo de validade dos temas abordados; a reflexão sobre aspectos da realidade; o uso da linguagem comum e a ausência de estruturas rigidamente estabelecidas. Após conhecerem essas e outras características desse gênero textual, por meio das atividades de leitura e de análise, os alunos produziram suas próprias crônicas, tendo liberdade de inspiração para escolherem a temática.

Devido à possibilidade que o gênero crônica oferece de abordar quaisquer temas, deixar essa escolha livre para os estudantes foi uma oportunidade ímpar. Grande parte das turmas possuía um bloqueio opressivo com relação à escrita, por vezes demonstrando sentimentos de incapacidade diante dessa tarefa. No entanto, a liberdade temática e formal da crônica fez com que os alunos se sentissem à vontade ao produzirem seus textos. Esse pode ter sido um impulso significativo para o aprimoramento das habilidades escritas dos estudantes, motivando-os a escreverem mais e a desafiarem-se em outros gêneros textuais.

Na sequência, as bolsistas desenvolveram atividades voltadas ao gênero dissertação escolar e à estrutura de parágrafos, visando ao aprimoramento das habilidades argumentativas e o emprego dos mecanismos linguísticos necessários, para que cada produção alcance a interação efetiva com os sujeitos aos quais se destina, cumprindo com sua função social. Essas propostas também foram aplicadas atendendo às demandas da escola, no que se refere à leitura e à escrita.

\section{Conclusão}

O desafio deste trabalho foi percebido, principalmente, em atividades de escrita nas quais os estudantes demonstravam maiores dificuldades, expressando-se verbalmente sobre carências de práticas similares no contexto escolar. Nesse cenário, a contribuição do subprojeto, dentro de suas 
possibilidades e do tempo disponibilizado, deu-se no desenvolvimento do hábito de ler e de escrever gêneros textuais específicos, com o objetivo de promover o aprimoramento da competência comunicativa dos alunos em situações diversas.

Palavras-chave: Gêneros Textuais. Leitura. Escrita.

\section{Referências}

BRAGA, Regina Maria; SILVESTRE, Maria de Fátima. Construindo o leitor competente: atividades de leitura interativa para a sala de aula. São Paulo: Petrópolis, 2002.

PEREIRA, Cilene da Cunha et al. Gêneros textuais e modos de organização do discurso: uma proposta para a sala de aula. In: PAULIUKONIS, Maria Aparecida Lino; SANTOS, Leonor Werneck dos. Estratégias de leitura: texto e ensino. Rio de Janeiro: Lucerna, 2006. p. 27-58. 


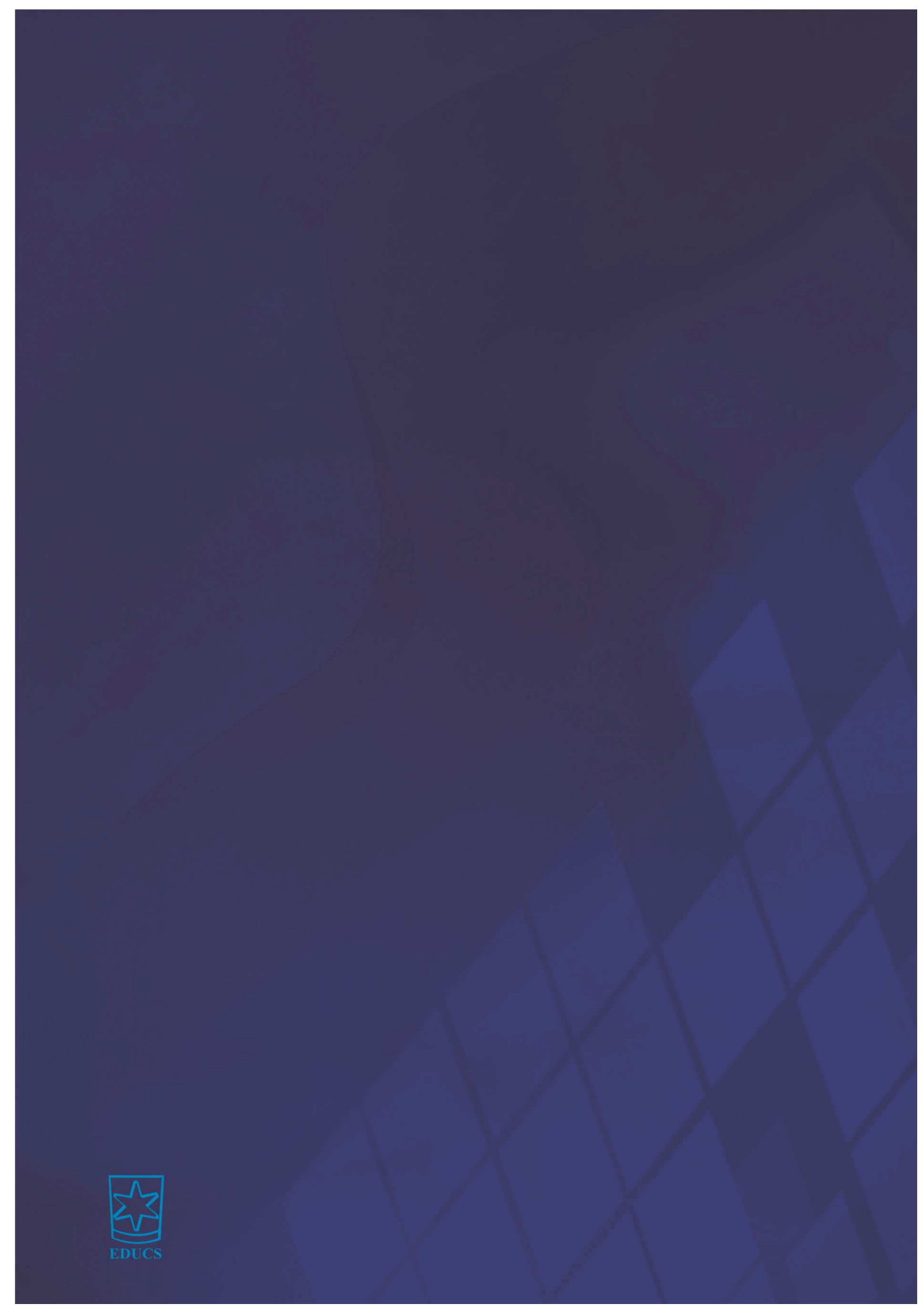

